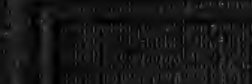

$$
\begin{aligned}
& \text { WITH THEF } \\
& \text { DOUGHBOY } \\
& \text { W FRANCE } \\
& \text { EDWARD HUNGERFO }
\end{aligned}
$$

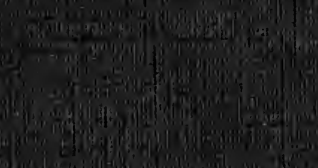

s. 4if inges 

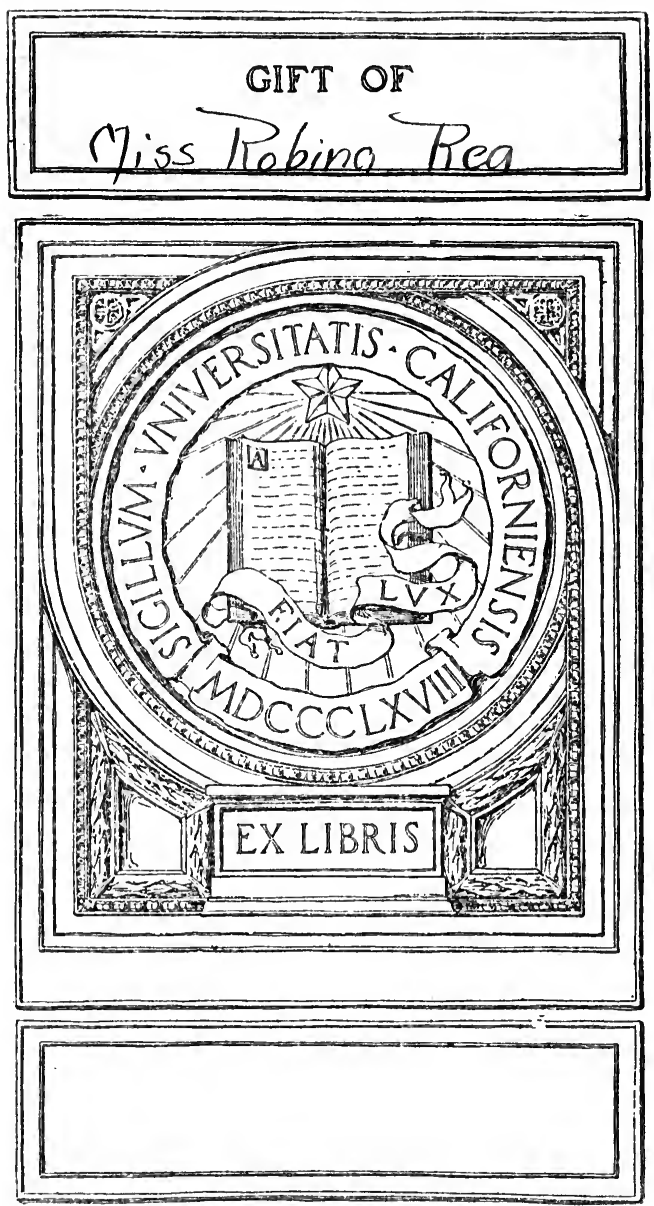
Digitized by the Internet Archive in 2007 with funding from - Microsoft Corporation 


\section{WITH THE DOUGHBOY IN FRANCE}




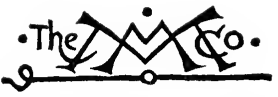

\section{THE MACMILLAN COMPANY \\ NEW YORK - BOSTON - CHICAGO - DALLAS}

ATLANTA - SAN FRANCISCO

MACMILLAN \& CO., Limited

LONDON - BOMBAY - CALCUTTA

MELBOURNE

THE MACMILLAN CO. OF CANADA, LTD. TORONTO 


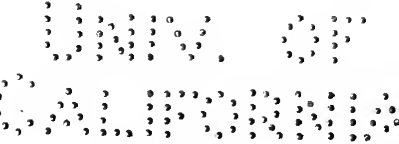




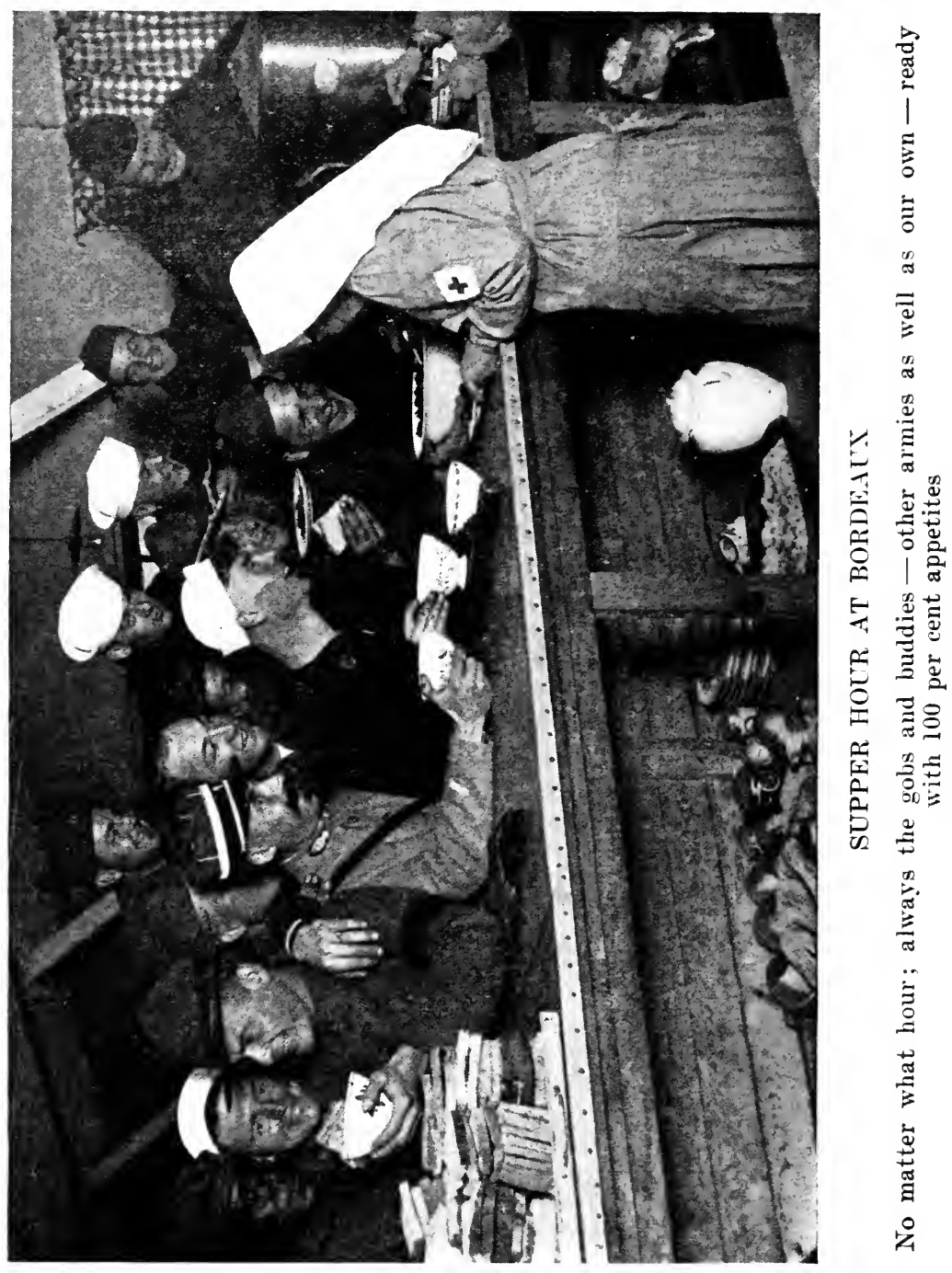




\title{
WITH THE DOUGHBOY IN FRANCE
}

\section{A FEW CHAPTERS OF AN AMERICAN EFFOR'T}

\author{
BY \\ EDWARD HUNGERFORD \\ Author of The Modern Railroad, The Personality \\ of American Citios, otc., otc.
}

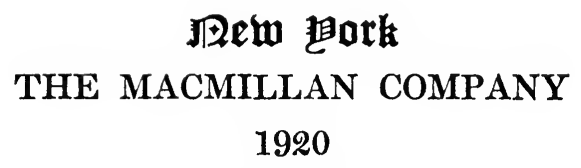

All rights reserved 


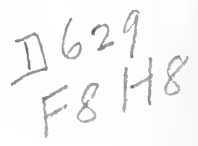

COPYRIGHT, 1920,

BY THE MACMILLAN COMPANY

Set up and electrotyped. Published November, 1920. 


\section{TO THE}

\section{CROIX ROUGE AMÉRICAINE}

The girl in the steel-gray uniform with the crimson crosses, who toiled and endured and danced and laughed and lived, that the heart and soul of the boy in khaki might remain untroubled, this book is affectionately inscribed 



\section{PREFACE}

Six months ago I finished writing the chapters of this book. At that time the American Red Cross still had a considerable force in Paris - throughout France for that matter. It was still functioning and, after its fashion, functioning extremely well. In the language of the French it "marched." To-day its marching days in the land of the lilies are nearly over. The personnel have nearly all returned home; the few that remain are clearing and packing the records. In a short time the Croix Rouge Americaine which for months was so evident in the streets of the French capital will be but a memory along the Boulevards. But a memory of accomplishment not soon to be forgotten. If there is one undying virtue of the Frenchman it is that of memory. Seemingly he cannot forget. And for years the remembrance of our Red Cross in his land is going to be a pleasant thought indeed. Of that I am more than sure.

To attempt to write a history, that should be at all adequate as complete history, of a great effort which was still in progress, as the writing went forward, would have been a lamentable task indeed. So this book makes no pose as history; it simply aims to be a picture, or a series of pictures of America in a big job, the pictures made from the standpoint of a witnesser of her largest humanitarian effort - the work of the American Red Cross.

I should feel embarrassed, moreover, at signing my name to this book were any reader of it to believe that it was in any large sense whatsoever a "one man" production. The size of the field to be covered, the brief space of time allotted in which to make some sort of a comprehensive 
picture of a really huge endeavor, made it necessary for the author to call for help in all directions. The answers to that call were immediate and generous. It hardly would be possible within a single chapter of this volume to make a complete list of the men and women who helped in its preparation. But the author does desire to state his profound sense of indebtedness to Mrs. Caroline Singer Mondell, Mrs. Kathleen Hills, Miss E. Buckner Kirk, Major Daniel T. Pierce, Captain George Buchanan Fife and Lieutenant William D. Hines. These have borne with him patiently and have been of much real assistance. His appreciation is great.

This picture of an American effort tells its own story. I have no intention at this time or place to attempt to elaborate it; but merely wish in passing to record my personal and sincere opinion that, in the workings of our Red Cross overseas, there seemed to me to be such an outpouring of affection, of patriotism, of a sincere desire to serve as I have never before seen. It was indeed a triumph for our teachings and our ideals.

New York - January, 1920.

E. H. 


\section{CONTENTS}

\section{CHAPTER I}

America Awakens .

\section{CHAPTER II}

Our Red Cross Goes to War • • • • • • • • 6

\section{CHAPTER III}

ORGANIZING FOR WORK • . . . . • • • • • • • 13

\section{CHAPTER IV}

The Problem of Transport • • • • • • • • • • • •

\section{CHAPTER V}

The Amerioan Red Oross as a Department Store • • 80

\section{CHAPTER VI}

The Dovghbor Moves Toward the Front . . . . . 100

\section{CHAPTER VII}

The Red Cross on the Field of Honor . . . . 128

\section{CHAPTER VIII}

Our Red Cross Performs Its Supreme Mission . . . 182 
CONTENTS

CHAPTER IX

PAGE

The Red Cross in the Hospitals of the A. E. F. • . . 208

\section{CHAPTER X}

“Pack Up Your Troubles in Your Old Kit BaG" . . . 238

CHAPTER XI

When Johnny Came Marching Home . • • . . . 259

CHAPTER XII

The GIRL Who Went to War $\mathrm{W}_{\mathrm{A}}$. . . . . . . . . 278 


\section{ILLUSTRATIONS}

Supper Hour at Bordeaux . . . . . . . Frontispiece No matter what hour; always the gobs and buddies other armies as well as our own - ready with 100 per cent appetites.

So This Is Paris . . . . . . . . . . . . . . . . A. E. F. Boys, guests of our A. R. C. in its great hospital at St. Cloud, look down about the "Queen City of the World."

Chоw

The rolling kitchens, builded on trailers to motor trucks, brought hot drinks and food right up to the men in action.

Our Red Cross at the Front . . . . . . . . . 100 A typical A. R. C. dugout just behind the lines.

As Seen from Aloft .

The aeroplane man gets the most definite impression at the A. R. C. Hospital at Issordun, which was typical at these field institutions.

Tickling the Old Ivories

Many an ancient piano did herculean service in the A. R. C. recreation huts throughout France.

Bandages by the Tens of Thousands. 220

An atelier workshop of the A. R. C. in the Rue St. Didier, Paris, daily turned out surgical dressings by the mile.

NEver SAY DIE .

Sorely wounded, our boys at the great A. R. C. field hospital in the Auteuil race track outside of Paris, kept an active interest in games and sports. 



\section{WITH THE DOUGHBOY IN FRANCE}

\section{CHAPTER I}

AMERICA AWAKENS

$\mathrm{N}$ that supreme hour when the United States consecrated 1 herself to a world ideal and girded herself for the struggle, to the death, if necessary, in defense of that ideal, the American Red Cross was ready. Long before that historic evening of the sixth of April, 1917, when Congress made its grim determination to enter the cause "for the democracy of the world," the Red Cross in the United States had felt the prescience of oncoming war. For nearly three years it had heard of, nay even seen, the unspeakable horrors of the war into which it was so soon to be thrust. It had witnessed the cruelties of the most modern and scientific of conflicts; a war in which science seemingly had but multiplied the horrors of all the wars that had gone before. Science and kultur between them had done this very thing. In the weary months of the conflict that began with August, 1914, the American Red Cross had taken far more than a merely passive interest in the Great War overseas. It had watched its sister organizations from the allied countries, already involved in the conflict, struggle in Belgium and France and Russia against terrific odds ; it had bade each of these "Godspeed," and uttered many silent prayers for their success. The spirit of Florence Nightingale and Clara Barton still lived - and still enthused.

It would have been odd - almost inconceivable, in fact 
- if anything else had been true. It would have been unpardonable if the American Red Cross had not, long before our entrance into the conflict, scented that forthcoming step, and, having thus anticipated history, had failed to make the most of the situation. We Americans pride ourselves as a nation upon our foresightedness, and an institution so distinctly American as the American Red Cross could hardly fail to have such a virtue imbedded in the backbone of its character.

Ofttimes, as a boy, have I read of the warriors of long ago, and how, when they prepared for battle, it was their women - their wives and their mothers, if you please,who girded them for the conflict; who breathed the prayers for their success, and who, whether or not they succeeded in attaining that success, bound up their wounds and gave them comfort upon their return. Such is the spirit of the Red Cross. The American artist who created that most superb of all posters, The Greatest Mother in the World, and who placed in the arms of that majestic and calmfaced woman the miniature figure of a soldier resting upon a stretcher, sensed that spirit. The American Red Cross is indeed the greatest mother in the world, and what mother - what American mother in particular - could have failed in the early spring of 1917 to anticipate the inevitable? Certainly none of the mothers of the hundred thousand or more boys who anticipated our own formal entrance into the Great War, by offering themselves - bodies and hearts and souls - to the armies of Britain, France, and Canada.

Other pens more skilled than mine have told, and will continue to tell, of the organization of the Red Cross at home to meet the certainties and the necessities of the oncoming war. For if America had not heretofore realized the magnitude of the task that was to confront her and had even permitted herself to become dulled to the horrors of the conflict overseas, the historic evening of the sixth of April, 1917, awakened her. It galvanized her from a 
passive repugnance at the scenes of the tragic drama being enacted upon the great stage of Europe into a bitter determination that, having been forced into the conflict, no matter for what reason, she would see it through to victory; and no matter what the cost. Yet cost in this sense was never to be interpreted into recklessness. Her boys were among her most precious possessions, and, if she were to give them without stint and without reserve - all for the glory of her supreme ideal - she would at least surround them with every possible requisite for their health, their comfort, and their strength. This was, and is, and will remain, the fundamental American policy.

With such a policy, where should America turn save to her Red Cross? And who more fit to stand as its spiritual and actual head than her President himself? So was it done. And when President Wilson found that the grave responsibilities of his other great war tasks would prevent him from giving the American Red Cross the detailed attention which it needed, he quickly appointed a War Council. This War Council was hard at work in a little over a month after the signing of the declaration of war. It established itself in the headquarters building of the Red Cross in the city of Washington and quickly began preparations for the great task just ahead.

For the fiber of this War Council the President scanned closely the professional and business ranks of American men. He reached out here and there and chose - here and there. And, in a similar way, the War Council chose its own immediate staff. A man from a New York city banking house would find his office or his desk - it was not every executive that could have an office to himself in those days - adjoining that of a ranch owner from Montana or Wyoming. The lawyer closed his brief case and the doctor placed his practice in other hands. The manufacturer bade his plant "good-by" and the big mining expert ceased for the moment to think of lodes and strata. 
A common cause - a common necessity - was binding them together.

\section{War!}

War was the cause and war the necessity. A real war it was, too - a real war of infinite possibilities and of very real dangers; war, the thing of alarms and of huge responsibilities, and for that war we must prepare.

It was said that America was unready, and so it was in a way. It was unprepared in material things - aëroplanes and guns and ships and well-trained men. But its resources in both money and in men who had potential possibilities of becoming the finest soldiers the world bad ever seen, were vast, almost limitless. And it was prepared in idealism, and had assuredly a certain measure of ability. It was prepared too to use such ability as it had in turning its resources - money and untrained men - into a fighting army of material things; material things and idealism. One thing or the other helped win the conflict.

"They said that we could not raise an army; that if we did raise it, we could not transport it overseas ; and that if we did transport it overseas, it could not fight - and in one day it wiped out the St. Mihiel salient."

These words tell the entire story - almost. Not that it becomes us Americans to talk too much about our forces having won the war. For one thing, it is not true. The British and the French armies also won the war, and if both had not hung on so tenaciously ours would not even be a fair share of the victory. But for them there would have been no victory, not on our side of the Rhine, at any rate, and men in Berlin, instead of in Paris, would have been dictating peace terms.

It is true, however, that without our army, and certainly without our moral prestige and our resources, the fight for democracy might have been lost at this time, and for many years hereafter. Count that for organization - for real 


\section{AMERICA AWAKENS}

American achievement, if you please. We builded a machine, a huge machine, a machine not without defects and some of them rather glaring defects as you come close to them, but it was a machine that functioned, and, upon the whole, functioned extremely well. It took raw materials - men among them - and fashioned them into fighting materials; fighting materials which flowed in one channel or another toward the fighting front overseas. And with one of these channels - the work of the American Red Cross with the Army of the United States in France this book has to do. 


\section{CHAPTER II}

OUR RED CROSS GOES TO WAR

O $\mathrm{N}$ the day that General John J. Pershing first came to Paris - it was the thirteenth of June, 1917 - the American Red Cross already was there. It greeted the American commanding general on his arrival at the French capital, an occasion long to be remembered even in a city of memorable celebrations. For hours the historic Place de la Concorde was thronged with patient folk. It was known that General Pershing was to be quartered at the Hotel Crillon - since come to a new fame as the headquarters of the American Commission to Negotiate Peace - and it was in front of the doors of that establishment that the crowd stood thickest. There were many, many thousands of these waiting folk, close-packed upon the pavement, and only giving way to a dusty limousine in which sat the man who was to help bring salvation to France and freedom to the democracy of the world.

After the doors of the hotel had swallowed General Pershing and his French hosts, the crowd refused to disperse; also, it became less patient. A long swinging chant began - the typical chant of the Paris mob. "Balcon, balcon, balcon," it sang in rhythmic monotony, and upon the balcony of the hotel in a few minutes Pershing appeared, while the crowd below him went wild in its enthusiasm.

But before the American commanding general had made his appearance upon the balcony he had been greeted in the parlors of the Crillon, both formally and informally, by the members of the first American Red Cross Commission to Europe. By coincidence that Commission had arrived in Paris that very morning from America, and were the 
first Americans to greet their high commanding officer in France. And so also to give him promise that the organization which they represented would be ready for the army as soon as it was ready; for back in the United States widespread plans for the great undertaking so close at hand already were well under way.

This American Commission had sailed from New York on the steamship Lorraine, of the French Compagnie Générale Transatlantique, on the second day of June. It consisted of eighteen men, headed by Major Grayson M.P. Murphy, a West Point man of some years of active army training and also a New York banker of wide experience. The other members of the party were James H. Perkins, afterward Red Cross Commissioner for France; William Endicott, afterward Red Cross Commissioner for Great Britain; Frederick S. Hoppin, Rev. Robert Davis, Rev. E. D. Miel, F. R. King, Philip Goodwin, Ernest McCullough, Ernest T. Bicknell, C. G. Osborne, R. J. Daly, A. W. Copp, John van Schaick, and Thomas H. Kenny. They were men who had been hastily recruited and yet not without some special qualifications for the difficult preliminary work which they were about to undertake. Until the preliminary "get-acquainted" luncheon which Major Murphy gave for the party in New York on the day preceding its sailing, comparatively few of them knew one another. Yet the great task into which they were entering was to make them lifelong friends, and to develop for the Red Cross, both in Europe and in America, many executives whose real abilities had not really been attained at the time of their appointment to Red Cross service.

These men were volunteers. With a few exceptions, such as clerical workers and the like, the early members of the Red Cross served without pay. At first they had no military rank. Apart from Major Murphy, who bore the title of Commissioner to Europe - there being at the time no separate Commissioner to France or to Great Britain - there were merely deputy commissioners, inspectors, 
and secretaries. Major Murphy's title had come to him through his army service. It was not until some time later that the War Department issued General Orders No. 82 (July 5, 1917), conferring titles and fixing the assimilated rank of Red Cross personnel. Accordingly commissions and rank were given and the khaki uniform of the United States Army adopted, with distinctive Red Cross markings. Though it is not generally understood, American Red Cross officers have received from the President of the United States, issued through and over the signature of the Secretary of War, commissions which appointed them to their rank and held them to the discipline and the honor of the United States Army.

Before the Lorraine was well out of the upper harbor of New York on that memorable second day of June, Major Murphy called a meeting of the Commission. He explained to them in a few words that they were, in effect, even then, military officers and would be expected to observe military discipline, and as a beginning would appear at dinner that evening in their uniforms - the army regulations at that time prevented relief workers of any sort appearing in the United States in their overseas uniforms - and thereafter would not appear without their uniforms until their return to America. The grim business of war seemingly was close at hand. It began in actuality when one first donned its accouterments, and was by no means lessened in effect by the stern war-time rules and discipline of a merchant ship which, each time she crossed the Atlantic, did so at grave peril.

Yet peril was not the thing that was uppermost in the minds of this pioneer Red Cross party. It took the many rules of "lights out" and "life preservers to be donned, s'il vous plaît," boat drill, and all the rest of this particularly grim part of the bigger grim business, good-humoredly and light-heartedly, yet kept its mind on the grimmer business on the other side of the Atlantic. And, so 
that it might become more efficient in that grimmest business, undertook for itself the study of French - at one and the same time the most lovable and most damnable of all languages.

"I shall not consider as efficient any member of the party who does not acquire enough French to be able to navigate in France under his own power in three months."

Major Murphy laughed as he said this, but he meant business. And so did the members of the Commission. As the ship settled down to the routine of her passage, the members of the Commission settled down to a life-anddeath struggle with French. For two long hours each morning they went at it. At first they gathered in little groups upon the decks, each headed by some one capable of giving more or less instruction; then they found their way to the lounge, where they grouped themselves round about a young woman from Smith College who had taught French in that institution for some years. It was this young woman's self-inflicted job to give conversational lessons to the Red Cross party, and this she did with both enthusiasm and ability. She chose to give them conversational French - in the form of certain simple and dramatic little childhood epics.

"This morning we will have the story of Little Red Riding Hood," she would say, "and after I am done telling it to you in French, you gentlemen, one by one, will tell it back to me - in French."

In order that the effect of the lesson should not be too quickly lost Major Murphy ruled that French, and no other language, should be both official and unofficial for luncheon each day. This order quickly converted an ordinarily genial meal intc a Quaker meeting. For when one of mademoiselle's more enthusiastic pupils would start an audacious request for " Encore le pain, s'il vous plaîl," he was almost sure to be greeted either with groans or grins from his fellows. Yet the lessons of those short ten days were invaluable. Many of the men of that party who 
since have attained more than a "navigating" knowledge of French have to thank the lady from Smith College for their opportunity to acquire it. The "bit" that she did for the Red Cross was perhaps small, but it was exceedingly valuable.

Afternoons, sometimes evenings, too, were given to business conferences wherein ways and means for meeting the big problem so close ahead were given attention. It matters not that many of the plans so carefully developed upon the Lorraine were, of necessity, abandoned after the party reached France. The very men who were making these plans realized as they were making them that field service - actual practice, if you please - is far different from theory, and as they planned, felt that the very labor they were undergoing might yet have to be thrown away, although not completely wasted. For the members of that pioneer Red Cross Commission were gaining one thing of which no situation whatsoever might deprive them; they were gaining an experience in teamwork that was to be invaluable in the busy weeks and months that were to follow.

Very early in the morning of the twelfth of June the Lorraine slipped into the mouth of the Gironde river; for the Compagnie Générale Transatlantique, driven from Havre by the submarine menace and the necessity of giving up the Seine embrochure to the great transport necessities of the British, had been forced to concentrate its activities at Bordeaux, the ancient port of the Gascogne country. The ship crossed the bar at the uncomfortable hour of three in the morning, and the Red Cross party first realized the fact that in army life night hours and day hours are all the same, when it was ordered to arise at once and face the customs and the passport inspectors. That inspection was slow work, yet not delaying. For the Gironde runs to the sea many miles after it passes the curving quay and the two great bridges of Bordeaux. The fact that the Lorraine was able to reach the quay well before noon was due not 
only to her being a good ship but to the fact that she had both wind and tide in her favor.

At fifteen minutes before twelve she docked and the Red Cross party faced the city of Bordeaux, flat yet not unimpressive, with the same graceful quay, the trees, and the old houses lining it, and in the distance the lofty spires of the lovely cathedral, with the even loftier spire of St. Michel in the farther distance. Even the uninitiated might see upon this last the complications of a wireless station and understand that here was one of the posts from which France spake far overseas.

It is but a night's ride from Bordeaux to Paris, even though it is close to four hundred miles between the two cities. That very evening Major Murphy and his party boarded the night train of the Orléans Railway for the capital, and had their first real touch of war's hardships. The night train was very crowded. It is nearly always crowded. It was then running a solitary sleeping car, but two or three of the older members of the party were able to get reservations. Still other fortunate ones were able to obtain seats. The rest of the party stood throughout the tiresome journey of twelve long hours. Major Murphy himself stood the entire night, akimbo over the prostrate body of a groaning, snoring poilu, yet was the first to be ready at the Gare d'Orsay on the morrow; to be here, there, and everywhere seeing that all were provided with proper hotel accommodations. After which he forged through the crowd to the Crillon, there to meet the hero of the day coming to Paris with "Papa Joffre"- and, like himself, every inch an American. After which again it was in order to repair to the American Relief Clearing House in the Rue François Premier to prepare directly for the big job now so close at hand.

I have described the voyage of this first Red Cross party overseas, not only because it was the first, but also because it was so very typical of many others to follow. Many 
and many a Red Cross man and Red Cross woman, to say nothing of veritable hosts of doughboys and their officers, had their first glimpse of lovely France as they sailed up the broad Gironde and into that lovely port of Bordeaux. The curving quay, the spires of the lovely cathedral, and the more distant but higher spire of St. Michel was the picture that greeted thousands of them. At least hundreds of them rode in the night train of the Orléans Railway to Paris, and in all probability stood the entire distance. For traveling in France in the days of the Great War was hard whether by train or by automobile.

Before I am done with this book I am going to describe the Atlantic crossing of one of the final Red Cross parties. I belonged to one of those parties myself and so am able to write from first-hand knowledge. But between the original expedition and the one in which I sailed were many others; others of far greater import. For our Uncle Samuel was aroused, and, once aroused, and having resolved that having entered the great fight he would give his all, if necessary, toward its winning, he began pouring overseas not only his fighting legions but his armies of relief, of which the Red Cross is part and parcel. 


\section{CHAPTER III}

\section{ORGANIZING FOR WORK}

A $\mathrm{T}$ No. 5 Rue François Premier stood the American A Relief Clearing House. It was a veritable lighthouse, a tower of strength, if you please, to an oppressed and suffering people. 'To its doors came the offerings of a friendly folk overseas who needed not the formal action of their Congress before their sympathies and their pursestrings were to be touched, but who were given heartfelt American response almost before the burning of Louvain had been accomplished. And from those doors poured forth that relief, in varied form, but with but one object, the relief of suffering and misery.

Until the coming of the American Red Cross and its kindred organizations, this Clearing House was to Paris - to all France, in fact - almost the sole expression of the real sentiment of the United States. It was organized, and well organized, with a definite purpose; on the one hand the avoidance of useless duplications and overlappings, to say nothing of possible frictions, and upon the other the heartfelt desire to accomplish the largest measure of good with means that were not always too ample despite the desire of the folk who were executing them. More than this, the American Relief Clearing House had a practical purpose in endeavoring to meet the everyday problems of transportation of relief supplies. This phase of its work we shall see again when we consider the organization of the transportation department of the American Red Cross in France. It is enough to say here and now that it possessed a very small number of trucks and touring cars which were worked to 
their fullest possibilities, and seemingly even beyond, in the all but vain effort to keep abreast of the incoming relief supplies.

In fact the American Relief Clearing House in its largest endeavors was in reality a forwarding agency and, although possessing no large transportation facilities of its own, made large use of existing commercial agencies and those of the governments of the Allies, to forward its relief supplies to their destination; whereupon it advised America not only of the receipt of these supplies but of the uses to which they were put. The main framework of the organization consisted of a staff of clerks who kept track of the movements of shipments and who saw to it that no undue delay occurred in their continuous transit from sender to recipient.

J. H. Jordain was the chief operating manager of this Clearing House, while Oscar H. Beatty was its DirectorGeneral. Closely affiliated with the success of the enterprise were Herman $\mathrm{H}$. Harjes, the Paris representative of a great New York banking house, a man whom we shall find presently at the head of one of the great ambulance relief works which preceded the coming of the American Red Cross, J. Ridgely Carter, James R. Barbour, and Ralph Preston. Mr. Preston crossed to France on the Lorraine with the preliminary party of survey and was of very great help at the outset in the formation of its definite plans.

The most dramatic feature perhaps of the American Relief Clearing House was the Norton-Harjes Ambulance Service, which was closely affiliated with it. This organization was founded in the early days of 1914 by two men, each acting independently of the other, who, by personal influence and a great amount of individual activity, succeeded in forming ambulance sections of the French Army maintained by American funds and manned by American boys and nurses who could not wait for the formal action of their government before flinging themselves into 
Europe's great war for world democracy. These two sections first were known as Sections Sanitaire $N u .5$ and $\mathrm{Nu}$. 6 of the French Army. At a later day it was found better policy, as well as more convenient and more economical, to merge these two sections. This was done, and the merged sections became known more or less formally as the NortonHarjes Ambulance Service.

At the time of the arrival of the American Red Cross in France this organization actually had in the field five sections of twenty cars each, two men to a car and two officers to a section. The men who offered themselves for this work were all volunteers and were, for the most part, college graduates and men of a disposition to give themselves to work of this sort. A spirit of self-sacrifice and selfdenial was represented everywhere within the ranks of the organization. To have been identified with the NortonHarjes service is to this day a mark of distinction comparable even with that of the ribbon of the Croix de Guerre.

The Red Cross in the United States, long before our actual entrance into France, had been helping this service with both money and supplies. It was quite natural therefore that it should take over this unit, which immediately assumed the name of the American Red Cross Ambulance Service. Between that time and the day on which responsibility for ambulance transport was taken over by the American Army, it organized, equipped and put in service eight additional sections. Before disbanding, the number of men had been brought to over six hundred, five hundred and fifty of them at the front and the remainder in training camp.

A third facility of the American Relief Clearing House which is worthy of passing note was the American Distributing Service, organized and financed by Mr. and Mrs. Robert W. Bliss of our embassy in Paris. It was first put in operation to furnish supplies to French hospitals throughout and behind the fighting areas. It operated a small warehouse in which many specialties - surgical in- 
struments for a particular instance - were received and in due turn distributed.

For a short time after the arrival of the first Commission from America, the possibility of affiliating the American Red Cross with the Clearing House was seriously considered. It became quite evident, however, that this would not be a feasible plan, but that the American Red Cross, just beginning to come into the fullness of its strength as a war-time organization, in order to attain its fullness of efficiency, would have to become the dominating factor of relief in France. This meant that the short but useful career of the American Relief Clearing House would have to be ended and its identity lost in that of the larger and older organization. This was done. The plant and the equipment and personnel as well of the Clearing House were formally turned over to the Red Cross Commission and its first headquarters offices established there in the Rue François Premier, while Mr. Beatty's title changed from Director-General of the Clearing House to that of Chief Executive Officer of the American Red Cross in France.

The offices in the Rue François Premier almost immediately were found too small for the greatly enlarged activities of the Red Cross, and so the large building on the corner of the Place de la Concorde and the Rue Royale, known as No. 4 Place de la Concorde, was engaged as headquarters. These premises were rented through Ralph Preston for $\$ 25,000$ a year and, although it was not so known at the time, this rental was paid by Mr. Preston out of his own pocket as his personal contribution to the work of the American Red Cross. Seemingly the new quarters were large indeed; yet what a task awaited the secretary when he was compelled to install a force of three hundred people in eighty-six rooms! The executive of modern business demands his flat-top desk, his push buttons, his letter files, his stenographer, his telephone, and "Num- 
ber Four" was a club building - originally a palace with crystal chandeliers and red carpets and high ceilings and all the things that go ordinarily to promote luxury and comfort, but do not go very far toward promoting business efficiency.

Yet the thing was managed, and for a time managed very well indeed. But as the work of our Red Cross in France progressed, "Number Four" grew too small, and from time to time various overflow, or annex offices were established near by in the Rue Bossy d'Anglais, the Avenue Gabriel, and the Rue de l'Elysée.

Yet in time these, too, were found insufficient. The army and the navy in France kept growing, and with them, and ahead of them, the work of the American Red Cross. Moreover, it was found in many ways most unsatisfactory to have the work of a single headquarters scattered under so many different roofs. So in June, 1918, these many Red Cross activities were brought under a single roof. With the aid of the French government authorities it was enabled to lease the six-story Hotel Regina on the Place de Rivoli and directly across from the Louvre. Into this far more commodious building was moved the larger portion of the American Red Cross offices in Paris, with the exception of the headquarters of the northeastern zone, which remained for a little longer time at No. 4 Place de la Concorde. Upon the signing of the armistice and the appointment of the American Commission to Negotiate Peace, the United States government, through the French, requisitioned both No. 4 Place de la Concorde and the Hotel Crillon for its peace headquarters. The headquarters of the northeastern zone of the Red Cross, much smaller with the coming of peace, were moved into the upper floor of the Hotel Regina.

In the meantime there were many, many changes in the American Red Cross in France other than those of mere location. Major Grayson M.-P. Murphy resigned as head of the French Commission early in September, 1917, leav- 
ing behind him a record for expertness and efficiency that has never been beaten. He was, in reality, merely borrowed from the United States Army, and to that organization, which then stood badly in need of both expertness and efficiency, he was returned, while his place as captain of our American Red Cross overseas was taken by one of his associates, Major James H. Perkins. Later this Red Cross chief attained the army rank of lieutenant colonel; yet with Perkins, rank did not count so very much at the best. To most of his fellow workers he was known as Major Perkins; yet, to many of them, "Jim Perkins" was the designation given to this much-loved American Red Cross officer. For if Major Murphy left behind him a splendid reputation for expertness and efficiency, Major James $H$. Perkins left his monument in Paris in the great affection which he gained in the hearts and minds of each of his associates. He won the love and respect of every man and woman in the organization. For here was a real man; a man who, if you please, preferred to gain loyalty - the quality so extremely necessary to any successful organization, whether of war time or of peace - through his own personality, his kindliness, and his fairness rather than by the authority vested in his office.

"It is impossible to exaggerate the whole-heartedness which Major Perkins gave to the upbuilding of our work here (France)," wrote Henry P. Davison, chairman of the War Council of the Red Cross at the time when the army, following its example in the case of Major Grayson M-P. Murphy, reached out and demanded Major Perkins's services for itself. He continued:

"We can understand the appeal that the army service makes to him, but we greatly regret the loss of his guidance and association. Whatever we have accomplished or may accomplish, it must never be forgotten that Major Perkins and Major Murphy were the pioneers who showed the way, who interpreted in practical fashion the desire of a whole 
nation to help through the Red Cross in the greatest cause to which a people ever gave their hearts and their resources. They, and we who carry forward the work of the Red Cross, will always be keenly sensible of what we owe to the energy, resourcefulness, and devotion which Major Perkins put into the task of developing from its beginning the mission of the Red Cross in the war."

And while I am quoting, perhaps I can do no better than to quote from a report of Major Perkins, himself, in which he summed up the work of the American Red Cross after its first year in France. He wrote:

"It is impossible for any one who has not had the experience of the last year in France to realize the difficulties which stood in the way of organizing an enormous quasi business, quasi relief organization; personnel was hard to get from America, supplies were hard to get, transportation was almost impossible, the mail service was bad and the telephone service was worse; but in spite of all these troubles the spirit with which the men of the organization undertook everything, carried things through in the most wonderful manner."

Spirit! That was Major Jim Perkins. His was a rare spirit; and the Red Cross men who had the pleasure and the opportunity of working under and with him will testify as to that. Spirit was one of the big things that made this captain of the Red Cross in the months when the difficulties of its task overseas were at high-water mark carry forward so very well indeed. Another was his rare breadth of vision. He, himself, still loves to quote an old French priest, whose parish children had been greatly helped by the work of our Red Cross among them.

"The American Red Cross is something new in the world," once wrote this venerable curé. "Never before has any nation in time of war scught to organize a great body to bind up the wounds of war, not only of its own soldiers but of the soldiers and peoples of other nations. 
Never before has so great a humanitarian work been undertaken or the idea in such terms conceived, and the result will be greater than any of us can now see."

So it was that Major Jim Perkins "saw big " - much larger, perhaps, than some of his associates at the time when the press of conflict was hard upon all of them. Some of these might have thought his plans large or even visionary; one or two frankly expressed themselves to that effect. Yet these were the very men who, when the Perkins ideas came into use, saw that they did not overshoot the mark.

It was under the régime of this Red Cross captain that the American Red Cross established a service to the French army in the form of canteens, hospitals, supplies, and money donations that led many of its commanders as well as several prominent French statesmen to remark that its steps along these lines were of inestimable value in maintaining the morale of the poilu and so in the final winning of the war. In later chapters of this book we shall describe in some detail the first canteen efforts of our Red Cross in France, and find how they were given to the faithful little men whose horizon blue uniform has come to designate tenacity and dogged purpose.

One of the very typical actions of the Military Affairs Department under Major Perkins was the help given to General Pétain's army, which had suffered acutely. His assistance came at a time which rendered it of double value to the French commander. In fact that was a trait of very real genius that Major Perkins displayed again and again throughout his management of the Red Cross - the knack of extending the aid of his organization at a time when its work would be of the greatest assistance to the winning of the war. In fact, it was upon his shoulders that there fell the task of directing our American Red Cross in meeting its two greatest military emergencies - the great German offensive in the Somme in March, 1918, and the bitter fighting in and about Château-Thierry some four months 


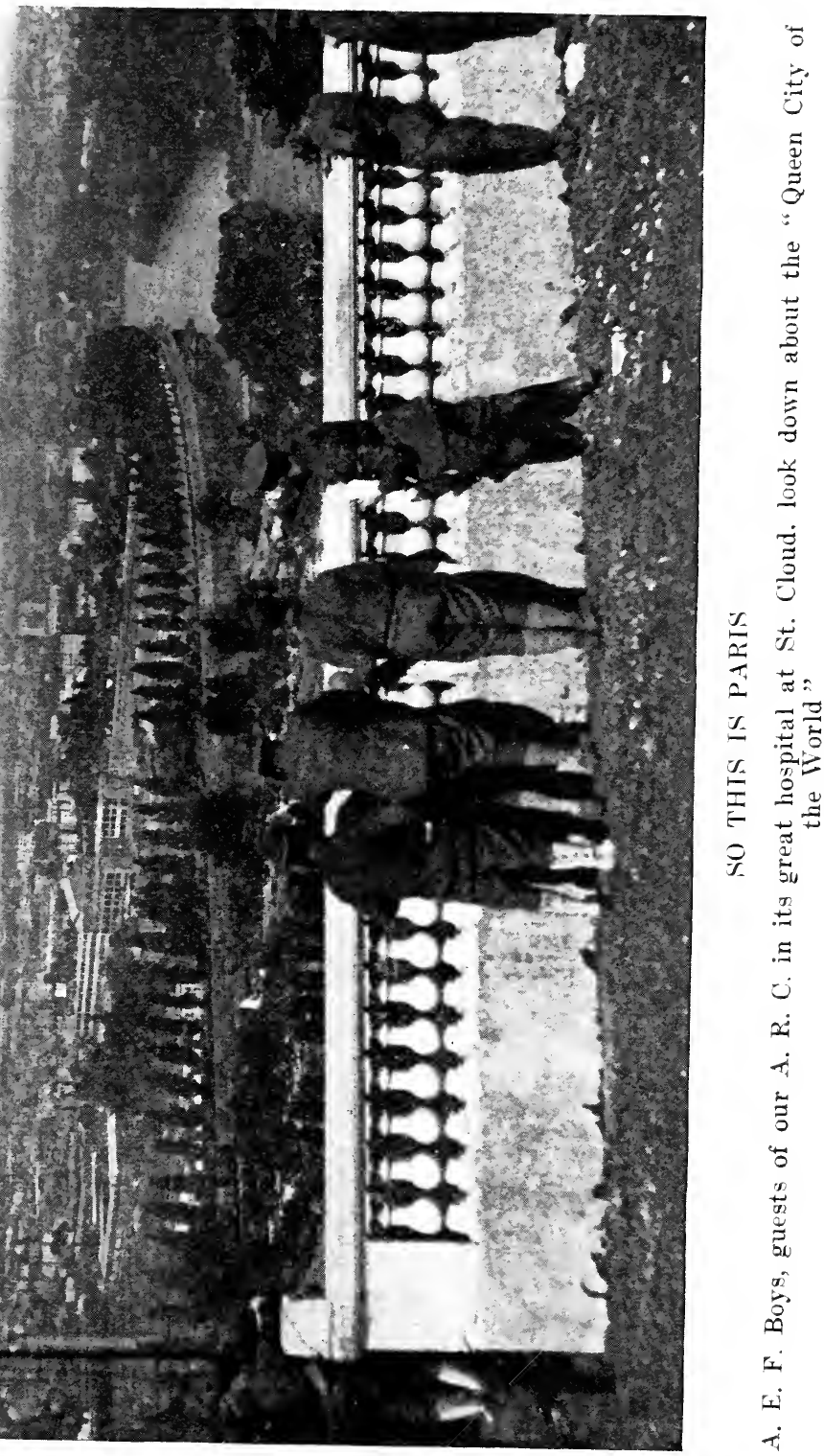



later. The official records of both the French and the American armies teem with communications of commendation for the efforts of the American Red Cross on those two memorable occasions.

Once in stating his policy in regard to the direction of the Red Cross Department of Military Affairs, of which he had been chief before succeeding Major Murphy as Commissioner to France, Major Perkins laid down his fundamental principles of work quite simply: they were merely to find and to develop the quickest and most effective way of helping the soldiers of the allied armies, and, particularly in the case of the United States Army, to put the Red Cross at the full service of every individual in it, not only in succoring the wounded but in making a difficult life as comfortable as was humanely possible for the well, and to perform these duties in the most economical and effective manner possible.

Here was a platform broad and generous, and, with the greatest armies that the world in all its long centuries of fighting has ever known, affording opportunities so vast as to be practically limitless. One might have thought that in a war carried forward on so unprecedented and colossal a scale that the Red Cross - or, for that matter, any other relief organization - might have found its fullest opportunity in a single activity. But seemingly that is not the Red Cross way of doing things. And in this particular war its great and dominating American organization was forever seeking out opportunities for service far removed from its conventional activities of the past, and of the things that originally might have been expected of it. Count so much for its versatility.

Consider, for instance, its activities in the field with the American Army - we also shall consider these in greater detail farther along in the pages of this book. The field service of the Red Cross in France - the distribution of such homely and needed man creature comforts as tobacco and toilet articles to the troopers in the trenches or close 
behind them - was a work quite removed from that started by women such as Florence Nightingale or Clara Barton. But who shall rise to say that, in its way, it was not nearly if not quite as essential?

It was this field service that Major Perkins inaugurated, then urged, and, in its earliest phases, personally directed. In addition he had charge of the first developments of the canteen or outpost services at the front. This consisted of the establishment of more or less permanent stations by the Red Cross as close to the front-line trenches as was either practicable or permissible. Open both day and night, these outposts took, at night under the cover of darkness, hot drinks and comforts to the men holding the trenches and at all hours took care of them as they came and went to and from the lines of advanced fighting.

When, slowly but surely, the American Army began to be a formidable combat force in France, the already great problems of Major Perkins were vastly increased. Up to that time the allied soldiers had been receiving the bulk of the assistance of our Red Cross. Now the balance of the work had to be changed and its preponderance swung toward our own army. Yet Perkins did not forget the grateful words and looks of thanks that he had received so many, many times from the poilus and all of their capitaines.

"Not less for the French, but more for the Americans," he quietly announced as his policy.

So it was done, and so continued. The sterling qualities of leadership that this man had shown from the first in the repeated times of great stress and emergency stood him in good stead. He already had instilled into the hearts and souls of the men and women who worked with him that consecration of purpose and enthusiasm for the work in hand which rendered so many of them, under emergency, supermen and superwomen. I have myself a high regard for organization. But I do believe that organization, without the promptings of the human heart to 
soften as well as to direct it, is as nothing. How often have we heard of the man with the hundred-thousanddollar mind and the two-cent heart. And how well we all know the fate that eventually confronts him.

To Harvey D. Gibson, who succeeded him as Commissioner to France in the summer of 1918, Major Perkins turned over an organization whose heart was as big as its mind, and then wended his own way toward the army, where he repeated so many of his successes in the Red Cross. But, as we have said, left behind him in this last - organization enduring memorials of great affection.

Eventually there came other big chiefs of our American Red Cross in France. Colonel Gibson returned to the United States in March, 1919, with the satisfaction of having done a thorough job thoroughly. He was succeeded by Colonel George H. Burr, as big-hearted and as broad in vision as Perkins. At the same time that Burr came to the seat of command in Paris, Colonel Robert E. Olds, whom Gibson had brought to Paris, became Commissioner for Europe. Between Burr and Olds there was the finest sort of team-work. The period in which they worked was far from an easy one. With the armistice more than three months past, with the constantly irritating and unsettling effect of the Peace Conference upon Paris and all who dwelt within her stout stone walls, with the mad rush of war enthusiasts to get back to the peace days in the homeland, with the strain and overwork of long months of the conflict finally telling upon both bodies and nerves, the necessity of maintaining the morale of the Red Cross itself, to say nothing of the men it served, was urgent. The dramatic phases of the work were gone. So was the glory. There remained simply the huge problem of orderly demobilization, of bringing the structure down to its original dimensions. A job much more easily said than done; but one that was done and done very well indeed. 
We have digressed from the days of the war. Return once again to them. In all that time there were many, many changes in our American Red Cross in Paris - one might fairly say, "of course." Men came and men went and plans and quarters were changed with a fair degree of frequency. But far more men - women, too - came than went, and moving days and plan changings grew farther and farther apart; for here was a definite and consistent planning and upbuilding of organization. If there is any one material thing upon which we Americans pride ourselves to-day more than another it is upon our ability to upbuild our efficiency through organization. And I think it is but fair to say if it had not been thoroughly organized much of the effort of the American Red Cross in France would have been lost. Commissions and commissioners might come and commissions and commissioners might go, but the plan of organization stood, and was at all times a great factor in the success of the work overseas.

The original plan of organization was simple. It did not, in the first instance, comprehend more than a Commissioner for Europe, with the bare possibility of other commissioners being appointed for the separate countries - if there should be found to be sufficient need for them. With the Commissioner for Europe was to be directly affiliated an advisory council, a bureau of legal advice and general policy, and various administrative bureaus and standing committees. The chief plan of the organization, however, divided the work of the American Red Cross in Europe into two great divisions: the one a department of civil affairs, which would undertake relief work for the civilian population of France, which in turn embraced the feeding, housing, and education of refugees, répatries, réformes, and mutilés, reconstruction and rehabilitation work in the devastated districts, and both direct and coöperative work in the cure and prevention of tuberculosis; and the 
other the department of military affairs, which undertook, as its province, military hospitals, diet kitchens, relief work for the armies of the Allies, medical and surgical and prisoners' information bureaus, medical research and nursing and hospital supply and surgical dressings services, canteens, rest stations and infirmaries, nurses' homes, movable kitchens, and the relief of mutilés. It is of the work of this latter department as it affected the boys of our army in France that this book is written.

Before Major Murphy, the first American Red Cross Commissioner to France, had proceeded very far with his work, he found that he would have further to divide and subdivide its activities. In connection with his deputy, Major James H. Perkins, he held several conferences with General Pershing who, day by day, was becoming better acquainted with the situation and the opportunities it offered. General Pershing stated quite frankly that in all probability it would be many months before his army would be an effective fighting force and that the Red Cross must, during those months, carry the American flag in Europe.

The first organization scheme comprehended several American commissions for the various countries in the zones of military activities, each independent of the other, but all in turn reporting to the Commissioner for Europe at Paris, who was responsible only to the War Council of the Red Cross at Washington. As a matter of actual and chronological fact the Commission to Belgium antedated the coming of the first Red Cross party to France. Long before even that stormy and historic April evening when the United States formally declared war upon the Kaiser and all the things for which the Kaiser stood, the American Red Cross was in Europe, helping to feed and clothe and comfort ravished Belgium. And its Commissioner ranked only second in importance to Herbert C. Hoover, who was in entire charge of the situation for America.

So, with its activities increasing, the Red Cross further 
divided its work. In the fall of 1917, Major Perkins became Commissioner for France and a short time afterwards separate commissioners were appointed for Great Britain, for Italy, for Switzerland, for Belgium, and for other countries. And these in turn appointed their own individual organizations, complete structures erected for business efficiency and to get a big job done quickly and well.

All this sounds simple, but it was not; for it is one thing to accomplish business organization, and accomplish it quickly, here at home in a land which has barely been touched by the ravages of war and not at all by invasion, and quite another to set up such a structure in a land shellshocked and nerve-racked and man-crippled by four years of war and actual invasion. Poor France! The war smote hard upon her. By the time that the Murphy Commission reached her shores she had even abandoned the smiling mask which she had tried to carry through the earliest months of the conflict. In Paris the streets were deserted. By day one might see an omnibus, or might not. Occasionally an ancient taxi carriage drawn by an ancient horse, too decrepit for service of any sort at the front, might be encountered. By night the scene was dismal indeed. Few street lights were burning - there was a great scarcity of coal and street lights meant danger from above, from the marauding raids of the great airships of the boche. The few street lamps that were kept alight as a matter of safety and great necessity had their globes smeared with thick blue paint and were but faint points of light against the deep blackness of the night. So that when the glad day of armistice finally came and the street lights blazed forth again - if not in their old-time brilliancy at least in a comparative one - Paris referred to the hour as the one of her " unbluing."

The difficulties of obtaining materials, even such simple office materials as books and blanks and paper, to say nothing of typewriters and the more complicated paraphernalia, 
the problem of service of every sort-clerical, stenographic, telephone, repair - can easily be imagined. There were times when to an ordinary business man they would have seemed insurmountable; but the Red Cross is not an ordinary business man. It moves under inspiration - inspiration and the need of the moment. And so it does not long permit difficulties, either usual or abnormal, to block its path.

To reduce all of this to organization was a distinct and difficult problem. Our Red Cross which had jumped into the French civilian and military situation while it awaited the coming of the first troops from America, first organized in practically the only way that it was possible for it to organize. It found men in big jobs - some of those very activities that we found more or less correlated in the work of the American Relief Clearing House - and told other men to take other big jobs and work them out in their own way.

This was far from ideal organization, of course. It meant much duplication and overlapping of functional work - in purchasing, in transportation, personnel, and the like. But it was the only sort of organization that was possible at first, and for a considerable time afterward. By the fall of 1917, when Commissioner Perkins had settled down to the details of his big new job and was ready to take up the reorganization of the Red Cross activities in France, there came the great drive of the Austrians and the Germans against the Italian front, with the direct result that the American Red Cross organization in Paris was called upon to bend every effort toward rushing whole trainloads of workers and supplies southward toward Italy. And in the spring of 1918 came the last great drive of the Germans in France - that supreme hour when disaster hung in the very air and the fate of the democracy of the world wavered.

Yet the first half of 1918 was not entirely spun into his- 
tory before the Red Cross in France was beginning its reorganization. The third Commissioner for France, Harvey D. Gibson, had been appointed and by June was on his way to Paris. One of the first of the huge tasks that awaited him - for it then seemed as if the war was to last for years instead of but four or five months longer - was this very problem of reorganization. Without delay he set upon it, and with the help of his Deputy Commissioner and assistant, George Murnane, evolved an entirely new plan, which gave far larger opportunities for the development of the American Red Cross in France and was, in fact, so simple and so logical in its workings as to become the permanent scheme of organization.

Let me emphasize and reiterate: the old plan, with its two great separate departments of military and civilan affairs, was not only not essentially a bad plan, but it was the only plan possible with the conditions of great stress and strain under which our Red Cross began its operations in France. But it was quickly outgrown. It did not and could not measure up to the real necessities of the situation.

"The double program of the Red Cross, under two large departments of military and civilian affairs," wrote Elizabeth Shipley Sergeant, of this older plan in The New Republic, ". . . followed a good Red Cross tradition and seemed to be based on a genuine separation of the problems involved. The great crisis in France a year ago was a civilian crisis, and the distinguished American business men who directed the Red Cross were wise enough to associate with themselves specialists in social problems and to give them a free hand. The chiefs of the military bureau, some of whom, like the doctors, were also specialists, had no less a free hand. Indeed the situation was so complex and the necessities were so immediate that every bureau chief and every field delegate was practically told to go ahead and do his utmost. The result was great vitality, great enthusiasm, genuine accomplishment. ..."

In the twelve months that the American Red Cross 
had been established in France its work had multiplied many, many times; in but six months the size of the American Army there had quadrupled, and the end was by no means in sight. To plan an organization that would measure up to meet such vast growth and meet it adequately was no child's play.

To begin with, he decided that the great functional workings, such as those of which we have just spoken - transportation, supplies, personnel, construction, and the like - should be centralized in Paris and the great duplications and overlappings of the old system avoided. This, in turn, thrust far too great responsibilities and far too much detail upon those same Paris headquarters. So in turn he took from it its vast overload and divided the organization into nine zones, of which more in good time. If these zone organizations had been situated in the United States instead of in France it is quite possible that the functional activities might have been very largely concentrated at their several headquarters. For in our own land such things as personnel, transportation, supplies, and construction could be readily obtained at headquarters points - Boston, New York, Chicago, New Orleans, or San Francisco, for instance. In France they not only were not readily obtainalbe, but rarely obtainable at any cost or any trouble. Think of the difficulties of obtaining either motor trucks or canteen workers which confronted the zone manager at Neufchâteau, just back of the big front line! It was well that the plan of organization under which he worked provided definitely he was to requisition Paris for such supplies - human or material - and that in turn Paris might draw upon the great resources of America.

Such in brief was the plan. It was simplicity itself; yet was builded to measure to the necessities of the situation. And so it did measure - to the necessities of the situation. Time and experience proved that; also they proved the value of central bureaus, but did not segregate them as before under the separate headings of Military and Civilian. 
Instead there proved necessary seven "functional departments" - to be responsible for plans and programs and instructions for carrying on the work. The directors of those seven departments served as assistants to the administrative head of the American Red Cross, the Commissioner to France. Considering him as the commander in chief and his seven directors as his staff officers, the Red Cross in France began to take on a distinctly military form.

The seven departments were as follows:

Department of Requirements: Bureau of Supplies; Transportation; Personnel; Permits and Passes; Construction; Manufacture.

Medical and Surgical Department: Bureau of Hospital Administration; Tuberculosis and Public Health; Children's Bureau; Reëducation and Reconstruction; Nurses.

Medical Research and Intelligence Department.

Department of Army and Navy Service: Bureau of Canteens; Home and Hospital Service; Outpost Service; Army Field Service.

Department of General Relief: Bureau of Refugees; Soldiers' Families; War Orphans; Argiculture.

Department of French Hospitals.

Department of Public Information.

So much for the general, or staff, organization. It covered, of course, all France. Yet for practical operations France was divided into nine great geographical zones which in turn were subdivided into districts. Each zone possessed its own warehouses and supply and transportation organization, and in each the entire operating organization came under a single head, the Zone Manager, whose responsibility for his own particular area was similar to that of the Commissioner's authority for all France. The Zone Manager had on his staff representatives of any of the headquarters departments which might function in his area.

The scheme was simple, and it worked. Correspondence was free between headquarters at Paris and the individual 
workers in the field, but copies of all instructions were also sent to the Zone Managers - in some cases to district managers also - so that they might be properly informed and all the operations coördinated.

The nine zones of military operations with their headquarters were as follows:

Northern ...................... Havre

Northwestern .................... Brest

Western ................... St. Nazaire

Southwestern ................ Bordeaux

Southern .................. Marseilles

North Intermediate .............. Tours

South Intermediate ................ Lyons

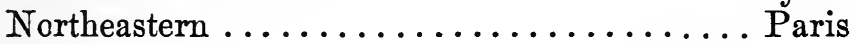

Eastern ................ Neufchâteau

Now consider, if you will, the workings of the seven great central bureaus, in so far at least as they concern the province of this book. The scheme for the Department of Requirements, as you may see from the table that I have just given, included not only the Bureau of Supplies, Transportation, Construction, and Manufacture - which we will consider in separate chapters - and Permits and Passes, but a section of General Insurance, to be responsible for all insurance matters except life insurance for Red Cross workers, which fell within the province of the Bureau of Personnel. The Medical and Surgical Department had its functions definitely outlined. It was stated that it was to be in charge of all the medical and surgical problems of the American Red Cross in France (except those specifically assigned to the Medical Research and Intelligence Department); that it was to formulate policies and to undertake a general supervision of medical and surgical activities. Moreover, it was to maintain the necessary contact with the United States Army and Navy authorities, so that the Red Cross could be prepared to ren- 
der prompt service in the event of medical or surgical emergencies. It was to be responsible for the determination of all medical and surgical American Red Cross standards; for decisions regarding supplies and manufactures for medical and surgical purposes; and for judgment regarding medical requisition. These things were set down with great exactness, and it was well that they should be; for the position of the Red Cross in regard to the medical departments of both the army and the navy has ever been a delicate as well as an intricate and helpful one. So it was, too, that it was determined that each of the nine zone organizations should include a Medical and Surgical Department representative who should report to the Zone Manager and be responsible for executing for him all the medical and surgical instructions received from headquarters as well as for the study and development of medical and surgical opportunities within the zone. It was further set down that this zone representative should be in charge of Red Cross hospital administration within its territory and should direct its operations at the American Red Cross hospitals, dispensaries, infirmaries, convalescent homes, and all similar activities.

The work of the Army and Navy Department also was expanded in great detail. And, inasmuch as all of its work comes so closely within the province of this book, I shall follow some of that detail. For instance, the plan of its organization set down not only the Bureaus of Canteens, the Home and Hospital Service, Outpost Service and Army Field Service, but also laid down the definite plans of action to be followed by each of these bureaus. Starting with the first of them, the Bureau of Canteens was to be responsible, through the zone organizations, for the development of this service - always so dear to the heart of the doughboy - throughout all France, for the inspection of its operations including reviews of its operating costs and for all activities regarding plans for the supplies, construction, and equipment of the canteens. The Head- 
quarters Bureau of this work at Paris was to develop instructions and formulate policies for the operation of these stations, but in the zones their actual operation was to fall under the jurisdiction of the local representatives of the Army and Navy Department who in turn, of course, reported direct to the Zone Manager controlling supplies and transportation movement in and out of the district. $f$

The Bureau of Home and Hospital Service was divided into three sections - great sections because of the vastness of the work that it might be called upon to perform for an army of two million, or perhaps even four million men. These were the Home Communication Section, the Home Service Section, and the Section of General Service at Military Hospitals. The task of the first of these sections - which presently we shall see amplified - was to obtain and transmit to the United States or to authorized army and navy officials in France and also to relatives in the United States, such information as might possibly be obtained in regard to dead, wounded, missing, or prisoner American soldiers or sailors. It was to be supplemental to and not in duplication of the service of the quartermaster of the United States Army. As a part of its work the section was to render aid in registering and photographing the graves of our soldiers and sailors.

At headquarters in Paris the work of the Home Communication Section was to be concerned with general executive direction, the determination of policies, the issuance of instructions, and the actual transcribing and forwarding of the reports to America. In the zones its activities were brought under the zone Army and Navy Bureau. Its actual work was planned to be conducted through searchers in the field, in camps, and in hospitals.

The Home Service work, while in a sense similar to that of the Home Communication Section, in another sense was quite the reverse. For while the first of these two services concerned itself with supplying the anxious mother back home with information regarding the boy from whom 
she had not heard for so long a time, it was the task of the Home Service also, through its representatives in the field, camps, or in hospitals (in many instances the selfsame representatives as those of the Home Communication) so far as possible to relieve the anxieties of soldiers regarding affairs at home.

The third section of the Home and Hospital Service bore the rather imposing title of Section of General Service at Military Hospitals. Its task was to assist in furnishing medical and surgical supplies to army and navy hospitals in accordance with the plans of the Medical and Surgical Department, to distribute general comforts to our sick and wounded, to erect and operate recreation huts at the hospitals, and even to develop gardens at the hospitals for furnishing fresh vegetables to patients - a part of the program which, because of the sudden ending of the war, was never quite realized. Furthermore, the work of this Section contemplated the operation of nurses' homes and huts. All of these activities were to be under the chief representative at the hospital whose task it was to correlate and direct all the operations.

Alongside of Home and Hospital Service in the army and navy stood the Bureaus of Outpost Service and of Army Field Service. In the plan for the first of these, the American Red Cross would endeavor to maintain at as many points as was consistently possible outposts at which supplies would be kept and comforts and necessities distributed to men in the line. From these points, as well as from points even in advance of their locations, emergency sustenance and comforts were to be given men at advanced dressing stations and at every other point along the front where our troops might actually be reached.

In the Army Field Service, the American Red Cross was to have, with each army division, a representative to cooperate with the Army Medical Corps to furnish supplementary medical and surgical supplies, to distribute supplies and comforts to troops, to perform such canteen serv- 
ice as was possible in emergencies, and for a general cooperation with the men working in the Home Communication and the Home services.

If I have taken much of your time with the rather lengthy details of this final war-time plan of organization of the American Red Cross in France, it is because one cannot well understand the results of a great machine such as it became - with more than six thousand uniformed workers in the field, the hospitals, the canteens, and the headquarters of France - without looking a little bit beneath its hoodings and its coverings and seeing something of the actual working of its mechanism.

I like, myself, to think first of the Red Cross in its vast humanitarian aspects; and yet the business side of the great organization, so far as I have had the opportunity of seeing into it, has fascinated me. To go behind the scenes of the greatest helping hand of all time and there see system, precision, and order, is a mighty privilege. The Headquarters building of the American Red Cross in the city of Washington is a monumental structure - an architectural triumph in white marble, planned as a great and enduring memorial long before the coming of the war. Even in the busiest days of 1918 its beautiful and restful exterior gave little evidence of the whirl of industry within and behind, for far to the rear of the main Headquarters building, designed, as I have just said, with no immediate thought of war, stretched great, plain emergency buildings, each a hive of offices and each peopled with hundreds of clerks, with desks and typewriters and telephones - all in coordination and all a part of the paraphernalia that goes to the making of the cogs and wheels and shafts and cylinders of the great modern machine of business of to-day.

Behind this building there were many other such headquarters structures - buildings here and there across the face of the United States and in some of the great capitals of Europe - Paris, London, Rome, Geneva, for instance. 
Of these, none more important, none busier than the headquarters of the American Red Cross in France, in the sixstoried Hotel Regina, Paris, in its turn a veritable hive of offices and peopled with more clerks, more desks, more typewriters, more telephones, and all this paraphernalia coordinated, as we have just seen, by modern and detailed business system.

Again behind these headquarters buildings still others; concentration warehouses in each of America's forty-eight states, to say nothing of her Federal capital; warehouses at ports of embarkation; warehouses at ports of debarkation; at central points in France, and points behind the firing line; huts, canteens, in some cases entire hospitals, motor trucks, camionettes, supplies in the hundreds of thousands of tons to go from the warehouses into the camions and back again into the warehouses, and ten thousand workers, six thousand in France alone. What a mess it all would have been without coördinated system, definitely laid down and definitely followed!

To have builded such a machine, to have laid down so huge and so definite a plan in the days before the war would seemingly have been a matter of long years. But we now know that the Red Cross is an emergency organization. In emergency it was developed - not in years, but in months, nay, even in weeks.

"We had to build an organization - and operate it all the time that we were building it," one of the Washington officers of the organization once told me. "We had to start to get actual materials and supplies for field relief work of every sort at the very hour and minute that we were sending our first working commission to France and were struggling to get a competent field relief organization. In every direction raw and inexperienced human material confronted us. We were raw and inexperienced ourselves. And yet, as we confronted the big problem and turned it over between us, we saw light. We began to realize certain definite things. We realized, for instance, that when we 
needed an executive to supervise the turning out of many hundreds of millions of hospital dressings, we did not, after all, need a nurse or a doctor, but a man or a woman who had the experience or the technique to turn out dressings in huge quantities. We needed an executive. We found such a man in the person of a lumberman out in the Middle West. We brought him to Washington and there he made good on the job."

These experiences were paralleled in Paris even through the exigencies of the situation, the extreme emergency which at all times confronted our Red Cross there, until the fateful eleventh hour of the eleventh day of the eleventh month of 1918 had been met and long since passed. It therefore was not always possible to pick executives with such care and discrimination as would be possible in the United States; in fact the best results were obtained by the more or less firmly fixed method of finding the personnel here - generally in response to definite cable requests from Paris - and sending it to France, but not always. Occasionally the reverse was true. Men already overseas were thrust quite unexpectedly into posts of great trust and great responsibility posts requiring broad and instant initiative - and in those posts developed abilities which they, themselves, had not realized they possessed.

In fact it is worth stating that the zone plan of organization contemplated this very possibility, and so gave to each Zone Manager great autonomy and freedom of action. In no other way would it have been possible to obtain immediate and efficient results, particularly in a war-beset land where communication of every sort, by train, by motor car, by post, by telegraph, and by telephone, was so greatly overburdened. The very autonomy of the final organization plan was largely responsible for its success. It was one of the lubricants which made the big business machine of the American Red Cross in France function so well.

Have you ever stood beside a fairly complex machine - 
a linotype or a silk loom or a paper machine, for instance - and after examining its intricacy of cams and cogs and shafts, wondered how it turned out its product with such precision and rapidity? So it is with the big business machine of the American Red Cross. You might stand close to any one of its many, many individual activities - the sewing room of a chapter house here in the United States, a base hospital behind the front in France, a transport receiving its medical supplies - and wonder truly at the coördination of such huge activities; for they did coordinate. The big machine functioned, and as a rule functioned very well indeed. And because it did function so very well the largest single humanitarian effort in the history of the world was carried forward to success with a minimum of friction and loss of precious energy.

So much, if you please, for practical business methods in an international emergency. 


\section{CHAPTER IV}

\section{THE PROBLEM OF TRANSPORT}

TO attempt aid or comfort to a fighting army six hun1 dred miles inland from the coast without adequate transportation was quite out of the question. Transportation, in fact and in truth, was the lifeblood of the American Expeditionary Forces which began to debark at the Atlantic rim of France before the summer of 1917 was well spent. It was the obvious necessity of transportation that made it necessary for the War Department of the United States to plan to operate an American railroad system of some 6,000 miles of line - all told about equal to the length of the Northern Pacific system - over certain designated portions of the several French railway systems. Nothing was ever more true than the now trite Napoleonic remark, that an "army travels on its stomach." The imperial epigram about the progress of an army meant transportation, and little else.

In other days in other wars the transport of the United States was in the completely adequate hands of its Quartermaster General and its Corps of Engineers. But in those days we fought our wars in North America. The idea of an army of two million men - perhaps even four or five million - fighting nearly four thousand miles away from the homeland was quite beyond our conception. When that remote possibility became fact the necessities of our transport multiplied a thousandfold. They swept even beyond the capabilities of a Quartermaster General and a Chief of Engineers who found their abilities sore-taxed in many other directions than that of the water, the rail, and the highway movement of troops. It became a job 
for railroad men, expert railroad men, the most expert railroad men in the world. And where might railroad men be found more expert than those of the United States of America?

Purposely I am digressing for the moment from the Red Cross's individual problem of transport. I want you to see for an instant and in the briefest possible fashion, the United States Military Railroad in France, not alone because it must form the real and permanent background of any study of the transportation of the American Red Cross - itself a structure of no little magnitude - but also because in turn the Red Cross was able to render a large degree of real service to the railroad workers who had come far overseas from Collingwood or Altoona or Kansas City to run locomotives or operate yards or unload great gray ships. No Red Cross canteens have been of larger interest than those which sprung up beside the tracks at Tours or Grievres or Neufchâteau or St. Nazaire or Bassens - all of these important operating points along the lines of the United States Military Railroad in France.

To run this Yankee railroad across the land of the lily required, as already I have intimated, expert railroad mentality. To head it no less a man than W. W. Atterbury, operating vice-president of the Pennsylvania Railroad, was chosen and given the rank of brigadier-general in charge of the rail transport of the S. O. S., as the doughboy and commissioned officers alike have come to know the Service of Supplies of the American Expeditionary Forces. Around himself General Atterbury assembled a group of practical railroaders, men whose judgment and experience long since have placed them in the front rank of American transportation experts. Among these were Colonel W. J. Wilgus, former engineering vice-president of the New York Central system and the man who had made the first studies of the necessities and the possibilities of the United States Military Railroad in France; Colonel James A. McCrea, a son of the former president of the Pennsylvania and him- 
self general manager of the Long Island Railroad at the time of our entrance into the war; Colonel F. A. Delano, a one-time president of the Wabash, who left a commissionership in the Federal Reserve Board to join the army, and Colonel G. T. Slade, former vice-president of the Northern Pacific. These men are only a few out of a fairly lengthy roster of our Yankee railroad men in France. Yet they will serve to indicate the type of personnel which operated our lines in France. It would not be fair to close this paragraph without a reference to the patent fact that the high quality of the personnel of the official staff of our Yankee railroad overseas was fully reflected in the men of its rank and file. These, too, were of the highest type of working railroaders, and to an American who knows anything whatsoever about the railroads of his homeland and the men who work upon them, more need not be said.

The United States Military Railroad in France, it should clearly be understood, was not a railroad system such as we build in America by patient planning and toil and the actual upturning of virgin soil. While many millions of dollars were expended in its construction, it was not, after all, a constructed railroad. In any legal or corporation sense it was not a railroad at all. It was in fact an adaptation of certain lines - side lines wherever possible - of long-existent French railways. To best grasp it, one must first understand that the greater part of French rail transportation is divided into five great systems. Four of these - the Nord, the Etat, the Paris-Lyons-Méditerranée, and the Orléans - shoot many of their main stems out from the heart of Paris, as the spokes of a wheel extend out from its hub. These spoke lines, if I may be permitted the phrase, long since were greatly overburdened with the traffic which arose from the vast army operations of the French, the British, and the Belgians. The problem was to make the French railway system bear upon its 
already much-strained back the additional transport necessities of our incoming army of at least two million men within the first twelve months of its actual operations.

Between the radiating spoke lines of the French railways leading out from the great hub of the wheel at Paris is a network of smaller and connecting lines, the most of them single-tracked, however. The whole structure, in fact, greatly resembles a huge spider's web; far more so than our own because of its more regular outlines. Colonel Wilgus and Colonel William Barclay Parsons, the designer of the first New York subway system, who accompanied him in the first inspection of the army transportation problem in France, quickly recognized this spider's web. And a little inspection showed them the great burden that its main spokes already were carrying; convinced them of the necessity of using other lines for the traffic of the American Army. For it was known even then that in addition to carrying the men themselves there would have to be some 50,000 tons a day transported an average distance of six hundred miles for an army of two million men.

To strike across the spider's web! That was the solution of the problem. Never mind if most of those crosscountry connecting lines running at every conceivable angle to the main spoke lines and in turn bisecting the greater part of them, were for the most part single-tracked. Never mind if, as they began to climb the hills of Eastern France which held the eastern portions of the battle front - sectors assigned quite largely to the Americans - they attained one per cent grade or better. In the valley of the Loire where a good part of our military rail route would be located there is the easiest and steadiest longdistance grade in all France. With American ingenuity and American labor it would be comparatively easy to double track the single-track lines and in some cases even to lower the gradients, while, for that matter, the ingenuity of American locomotive builders might rise quite easily to 
the problem of producing an effective locomotive to overcome these one per cent pulls.

I have spoken of the valley of the Loire because almost from the beginning it was chosen as the location of the chief main routes of the United States Military Railroad in France. Necessity dictated that location. It was both logical and efficient that the British should be given the great Channel ports for their supply service of men and munitions. Their endeavors so crowded Havre and Boulogne and Dieppe and Calais and Cherbourg, to say nothing of the rail lines which serve these ancient ports of the north of France, that they were out of the question for any large movement of American forces, although, as we shall see in good time, much Red Cross material, particularly in the early stages of our participation in the war, did come through Havre.

The more distinctly American ports, however, were Brest, St. Nazaire, La Rochelle, and Bordeaux, as well as the rapidly created emergency port at Bassens, just across the Gironde from Bordeaux. All of these harbors are on the west coast of France and give more or less directly in the Atlantic Ocean itself. With the possible exception of Bordeaux, in recent years they have been rather sadly neglected ports. That no longer can be said, however, for within a space of time to be measured by weeks and months rather than by years, they have become worthy of rank with the most efficient harbors of the world. It was necessity that made them so - the supreme necessity of the greatest war in history. So does the black cloud of war sometimes have its silver lining of permanent achievement.

These were the ports that became the starting points of the two main stems of the United States Military Railroad in France. Upon the great docks and within the huge warehouses that sprang up seemingly overnight were placed the constantly incoming loads of men and mules and horses and food and guns and camionettes and tents and 
five-ton trucks - all the seemingly endless paraphernalia of war. And from those docks and from those warehouses moved at all hours of the day and night long trains emptying them of all that same endless paraphernalia of war and in the same good order as that in which it arrived. And these trains were for the greater part of American-builded cars, hauled by locomotives from the engine-building shops of Philadelphia or Schenectady or Dunkirk and all operated by 75,000 expert railroaders, picked and culled from every state of the Union.

I shall not attempt here to go into further detail of the operation of our military railroad in France, although there is hardly a detail of it that is not fascinating in the extreme. It is enough here and now to say that it functioned; that our "contemptible army" wiped out the Saint Mihiel salient in one day, and, what is perhaps far more important, there were comparatively few instances where an American soldier went for a day without his three good meals. If I were an artist I would like to paint a picture for the beginning of this chapter. And because it was for a book of Red Cross activities primarily, the painting would show the operations of the United States Army Transport on land and water as a huge motley of ships and trains and warehouses and cranes in a gray monotone in the background; while in the foreground in gay array one would find the motor trucks, the camionettes, and the touring cars of the Red Cross's own transportation department.

To that department we now have come fairly and squarely. And, lest you should be tempted to dismiss it with a wave of the hand and a shoulder shrug, let me ask if you have been a woman worker for the Red Cross somewhere in our own beloved country, if you ever have given more than a passing thought to the future of that gauze bandage that you made so deftly and so quickly and so many, many times? Did you ever wonder what became of 
the sweater, the helmet, or the wristlets which you knitted with such patient care and patriotic fervor? Or that warm and woolen gown which you took down from the closet hook with such a real sigh of self-denial - it still was so pretty and so new? How was it to reach some downhearted refugee of France?

It is comparatively easy to visualize the movement of the munitions of war across the three thousand miles of Atlantic and six hundred miles of France between our northeastern seaports and our front lines of battle - powder and food and uniforms and even aëroplanes and locomotives in giant crates. It perhaps is not quite as easy to trace, even in the mind's eye, the vast passage of the steady output of the $20,000,000$ pairs of patriotic hands from America to the boys at the front. It is a vast picture; a huge canvas upon which is etched at first many fine streams of traffic, gradually converging; forming rivulets, then rivers, and finally a single mighty river which, if I may continue the allegory without becoming too mixed in my metaphor, is carried overseas and across the entire width of the French republic. Sometimes the swift course of the river is checked for a time; the little still-water pools and eddies are the concentration stations and warehouses in America; and the other pools and eddies in France are where the precious relief supplies are held for careful and equitable distribution.

To the streams that have poured out of the homes and the Chapter workrooms that have supported the Red Cross so loyally and so royally, must be added the great floods of traffic, of purchased raw materials and supplies of every sort. Some of these last, like the output of the home workshops, will go to the boys at the front practically unchanged. But a considerable quantity will be filtered through huge Red Cross workshops in Paris and other European cities, yet also goes forward to the front-line trenches.

It is well enough to look for a time at this huge problem 
as a great allegory or as a great picture; perhaps as one looks upon a great pageant. It has been a good deal more than that to the men who have had to be responsible for the successful working out of the problem. Come back behind the scenes and I shall try to show you the project as it appears to these men - a thing of hard realities and seemingly all but endless labor.

When Grayson M.-P. Murphy and his Commission made the preliminary survey trip to France in the interests of the American Red Cross in June, 1917, they took the man who was to solve their transportation problem right along with them. He was and still is Major Osborne. There have been changes in the Red Cross personnel since first the American organization took up its big part of the international job at Paris. Men have come and men have gone. Big executives - five, ten, twenty-thousand-dollara-year men a plenty - have slammed down their desks in New York or Pittsburgh or Chicago or San Francisco and have given six months or a year willingly and gladly to the service of the Red Cross. For many of them well past the army age it seemingly was the only way that they could keep pace with their boys or their nephews in khaki. But Osborne did not measure his service by months. He came with the first and remained on the job until long months after the signing of the armistice.

I wish that I might write of C. G. Osborne as some veteran American railroader or at least as a man experienced in motor truck or highway transportation of some sort. For when one comes to measure the size of the job and the way that he measured up to it, it seems incredible that he has not had large transportation experience of some sort. Yet when the truth is told it is known that Major Osborne is a college man, with an astounding record as an athlete, but with little more actual traffic experience than falls to the lot of any average business man. Perhaps, after all, that was just as well, for to his big new 
job he not only brought vigor and strength but a freshness of mind that made him see it in all the breadth of its possibilities.

There were eighteen men in that pioneer survey party of the American Red Cross to France. Before the ship had left her dock in New York, Osborne was on his big new job, wiring the American Relief Clearing House in Paris which at that time was the unified agency for all the American relief work of every sort that had sprung up in France since the war began in August, 1914, to buy six touring cars and to have them at Paris to meet the party. The American Relief Clearing House moved quickly. It already possessed three Renaults - good cars of a sort well suited to the hard necessities of the war-scarred highroads of France. It purchased three more touring cars of the same general type, and in these six cars the American Red Cross took its first real look at the field into which it was to enter - the field in which it was destined to play the greatest rôle in all of its eventful career.

The Clearing House, it should be understood quite clearly, was not at any time a war-relief agency upon its own account. It was, as its name indicates, a real clearing house or central station for a number of American relief organizations who came to the aid of the French long before the United States had entered the war, and the American Red Cross was privileged legally to enter into the relief work in connection with it. It received goods - sweaters, socks, medicines, even food - from the states and from England and distributed them, although not even this work was undertaken directly, but was handled through transitaires, who made the direct distributions. Because of the rather limited nature of its work, therefore, it needed little actual equipment. In June, 1917, it only owned eight touring cars and three trucks; and all of these were pretty badly shot to pieces by hard service and by lack of repairs. But these it turned over to the Red Cross and they became 
the nucleus of the American Red Cross transportation organization in France.

"What we are going to need here," said Major Osborne to his fellows before he had been on the new job a fortnight, " is to create a real transportation service and to build it up from the bottom. What I really have in mind is the organization of something like one of our express companies back in the United States."

If you know anything at all about our inland transportation system in America you must realize that our express companies - one of our most distinctive forms of national transportation, by the way - although closely related to our railroads are in no real sense a part of them. For, while they have their largest functions upon railroad trains, particularly passenger trains, they also maintain in all the towns and cities that they serve great fleets or squadrons of horse-drawn or motor-drawn trucks. And in recent years they have increased their carrying functions from the small parcels for which they originally were designed into the heaviest types of freight. I have known a carload of steel girders to move from New York to Newark, eight miles distant, by express.

Osborne's idea of the Red Cross Express was fundamentally sound, and perhaps it is because it was so fundamentally sound that it has been so very successful, although working many times against tremendous odds. He recognized from the first that it would be foolish to use Red Cross motor trucks for long-distance hauls, such as from Havre to Paris, for instance, save in cases of great emergency. The railroad service of France, although greatly hampered and handicapped during the war, was at no time broken down. And it was not necessary, as in Great Britain and in the United States, to take it out of the hands of its private owners and place it under direct government control.

Osborne realized that he would be compelled to place his chief reliance upon the French railways. The United 
States Military Railroad, especially at the outset, was not to be compared in value with that of the the main stems of the French systems, particularly those which radiate out from Paris. So he made immediate arrangements with the French Minister of Railways for the transport of Red Cross supplies from the various Atlantic ports to Paris and other distributing stations as well as right up to the railheads behind the lines themselves. And the French on their part generously and immediately gave free transportation to all Red Cross supplies, as well as to all persons bound to any part of France exclusively on Red Cross work. In addition arrangements were made by which the Red Cross personnel bound on vacation leaves or other personal errands through France might avail themselves of the very low passenger rates heretofore only granted to soldiers in uniform.

With his plan of utilization of the railroads for longdistance hauls firmly fixed, Osborne promptly went to work to organize his fleet of trucks and touring cars in the various cities of France where the American Red Cross has touched with its activities. That meant not alone the securing of sufficient motor cars of the various sorts necessary to the situation, but of garages and repair facilities of every sort; this last particularly difficult in a nation which for three years had been war-racked and hard put to it to meet her own necessities of motor transportation. But from a beginning of three trucks and eight touring cars from the American Relief Clearing House, whose activities were quickly absorbed by the Red Cross, a mighty fleet of trucks and camions and camionettes and touring cars slowly was assembled. Before Osborne had been in France a month he had purchased at Paris fifty-five sizeable trucks, twenty-five of which had been unloaded at Havre and which had been destined originally for an American firm in France and another thirty which were turned over by the French Minister of Munitions. The 
entire fifty-five trucks were all at work by the end of July, 1917, when the first of the relief supplies from America began to roll, a mighty tidal wave into France.

On November 11, 1918, the day that the armistice was signed and another great milestone in the progress of the world erected, the transport department of the American Red Cross in France possessed a mighty fleet of 1,285 trucks and touring cars, moving some 5,000 tons of supplies each week. The greater part of these were in actual and constant service, the rest being held in its great garages and shops for painting and repairs. To these shops we shall come in good time.

I would not have you think of the transport problem too largely as a problem of the motor truck, however. I should prefer to have you see another picture; this one a perspective - France rolled flat before your eyes, the blue Atlantic upon one side and the mountainous German frontier upon the other. Across this great perspective call it a map, if you will - are furrowed many fine lines. The spider web once again! Here are the railways radiating out, like spokes of the wheel, from Paris. Here are the mass of connecting and cross-country lines. And here the one of these that must remain impressed upon the minds of Americans - the double main stem of the United States Military Railroad in France reaching chiefly from the ports of Bordeaux and of St. Nazaire with fainter but clear defined tendrils from La Rochelle and Brest as well. And if the eye be good or the glass half strong enough one can see the steady line of American transports coming to these four harbors - the "bridge across the Atlantic" of which our magazine writers used to prate so glibly but a little time ago.

As I write, the list of the French ports at which the transport department of the Red Cross conducts its chief activities is before me. In addition to the four which have just been mentioned, one finds Toulon and Marseilles, 
upon the Mediterranean: Bassens, La Pallice, Nantes, Havre, Rouen, Dunkirk and Calais. Not all of these were American ports. Some of them were reserved exclusively for the British. But they were all ports for the American Red Cross, which frequently found it necessary or advisable to buy supplies, raw or manufactured, in England.

The bulk of our materials came, however, to the American ports; and at some of them our Red Cross maintained more than a merely sizable organization. At least at six, it had a captain, thirty or forty French or American helpers, and perhaps from seventy-five to a hundred boche prisoners who performed the hardest of the actual work upon the piers and within the warehouses. There was much work to be done. The plants were huge. In St. Nazaire, for instance, the Red Cross warehouse alone could hold more than eight thousand cases of supplies beneath its roof, and in course of the busiest days of the war, just before the signing of the armistice, it was no uncommon thing for this great warehouse to be completely emptied and refilled within seven days. At the one port of St. Nazaire it was necessary to assign six large trucks, and yet the movement of Red Cross supplies from this great port was exclusively upon the trains of the United States Military Railroad.

As fast as the freight came pouring out from the holds of the ships it was carted into the warehouses, where it was carefully checked and a receipt sent back to America, noting any shortages or overages. Then it found its way to the trains. If it was to an American train the process was simple enough; merely the waybill transaction which is so familiar to every American business man who ever has had freight dealings with our Yankee railroads. If it went upon the French railways, however, either in carload or less than carload lots, it rode upon the ordre de transport which, although issued and personally signed by Major Osborne, was the free gift of the French Minister of Railways. These ordres de transport differed from waybills 
chiefly in the fact that they give gross weights but no listing of the contents of the cases. This last was accomplished by the bordereaux, which was purely a Red Cross document.

The work of the port manager of the American Red Cross at one of these important water gates of France was no sinecure, indeed. Here is the testimony of one of the ablest of them, Mr. J. M. Erwin, who was in charge of its terminal transportation work, first at Le Havre and then at Nantes. He writes:

"In my branch of the activities I have performed no heroisms. I have not rushed out in the middle of the night to carry food or dressings to the front while dodging bombs or bullets, but I have crawled out of bed at five o'clock and six o'clock in the morning to wade through snow and mud in the quays, trying to boss the unloading of Red Cross goods from a ship and their transshipment to warehouse, car, or canal boat. I am like my confrères of other seaports in France - I haven't had a chance to expose my person to battle dangers - nothing more than the hazards of abnormal movement and traffic, tumbling cranes and falling bales, automobile eccentricities, climatic exposures, and a few similiar trifles.

"I have had my trials of dealing with the formalities of war departments, likewise with their machine-made exactions, and with all the types of Monsieur Le Bureau, with the general and the corporal, with the teamsters who arrive late - or not at all - with the auto truck which breaks down, with the boche prisoner gang which reports to the wrong place two miles away, with the vermin that steals things out of cracked cases, with the flivver that I can't start, with the navigation colonel who before the war was a plain clerk who wore store clothes, with the raikway station master who can't give me any cars, with 119 cases of jam that are 'busted' and must be repaired, at once, 
and atop of all this the rain which has been raining for seven weeks and won't stop."

The tone of the port manager's letter suddenly changes from sarcasm to the romance of his big job.

"If a bale or a case of goods could talk," he writes, " and tell you all about its trip from Spokane, Washington, to the emergency hospital near Château-Thierry, its narrative would form a chain story of freight cars and docks and stevedores, somber seclusion in a deep hold, tempests and submarines alert, the clanking of chains and the creaking of slings, shouts, orders, and oaths, bangings about in rain and snow, nails and cords yielding under the tension of rush and brutality, voices and hands of inimitable über alles prisoner teams, lonesome sleeps in dark warehouses, gnawings of nocturnal rats, more trips to the unknown, petite vitesse which averages five miles an hour, and - finally - destination, arrival, identification, application, and appreciation. The voyage and itinerary of a case of goods for the Red Cross compose an odyssey and very few human packages ever perform displacements so replete with incidents and interest."

Such indeed was the day's work of the port manager's job. He was master of transportation, and at a very vital point in transportation. No matter how much he might be assailed by questions or criticisms, until he wondered whether he really is a bureau of information or one of complaint, he never forgot that transportation was his real job, which brought to the A, B, C, of human endeavor, meant that he must see that the Red Cross supplies received at his port were properly checked and without delay shipped to their destinations. Paris was most generally this last.

Put yourself back into those stirring days. Suppose, if you will, that a certain definite shipment of Red Cross supplies comes into the headquarters city of Paris, 
either from Rouen or Le Havre or Brest or St. Nazaire. It comes through without great delay on the small but seemingly entirely efficient goods cars of a French railway to a great freight "quai" or warehouse, set aside for the exclusive use of our American Red Cross, not far from the busy passenger terminal of St. Lazaire. This huge raised platform, some six hundred feet long and fifty feet wide, handles some eighty per cent of all the Red Cross supplies that come into Paris in the course of the average month. All of the goods that come to this Parisian freight station are import and "in bond," and so at the great exit gates there is a squad of customs guards to inspect all outbound loads. But, again through the courtesy of the French Government, all Red Cross supplies are permitted to pass without inspection. Thus a great deal of time is saved and efficiency gained.

The little railway goods cars with the Red Cross supplies pull up along one side of the quai platform, while upon the other side stand the camions or trucks to carry the supplies down into Paris. Occasionally these are not destined for the French capital; in which case they are quickly transferred and reloaded to other little railway goods cars, and destined for other points in France. For the normal handling of freight upon this particular Red Cross quai - when, for instance, two or more ships arrive within a day of one another - the number of handlers and checkers may rise quickly to eighty-five or a hundred and then there may be as many as 15,000 cases of supplies upon the platform at a single time. The men employed are mainly French soldiers on leave or already demobilized, and are strong and dexterous workers. And upon one occasion they unloaded ninety-two closely packed freight cars in thirty-two hours.

In the course of an average war-time month this Paris receiving station for American Red Cross supplies would handle anywhere from 800 to 5,000 tons of cases a week, and despite the great weight of many of these cases - their 
is nothing light, for instance, in either medicines or surgical instruments - counts even the higher record as no extraordinary feat.

In addition to being a receiving station, this quai performed steady service as a sorting station or clearing house. From it some fifteen warehouses or stores depots in and about Paris received their supplies. And care must be taken that the goods for each of these warehouses must go forward promptly and correctly. The need for this care was obvious. It would be as senseless to send surgical dressing to one distribution center as stoves to another.

When any of these incoming supplies had been transferred from the railway quai to the distribution stations and a receipt taken for them, they were at once stricken from the records of the transportation department until, in response to a subsequent call, they were transferred out for delivery, either to the consumer or to another storage point in an outlying region, which is where the big fleet of Red Cross trucks in the streets of Paris began to fully function. The central control bureau, to which was delegated the routine but important work of the control of this great squadron of trucks, also had charge of the reception of merchandise arriving at the Seine landings on barges from the seaports of Rouen or Le Havre. For one must not forget that in France the inland waterway continues to play a large part of her internal transport. Not only are her canals and her canalized rivers splendidly maintained, but also owing quite largely to her comparatively mild winters, they render both cheap and efficient transportation. And the Seine, itself, sometimes brought a thousand tons a week into the Red Cross at Paris.

Now are we facing squarely the problem of the motor truck in Major Osborne's big department. I think that it was the part of the problem that has given him the greatest perplexity, and in the long run the greatest satisfaction. 
For, before we are arrived at the fullness of this phase of his service, please consider the difficulties under which his staff and himself labored from the beginning. France was at war for fifty-two months; not fighting a tedious and tiring war in some distant zone, but battling against the invasion of the strongest army the world ever has known and facing the almost immediate possibility of national collapse; which meant in turn, if not an industrial chaos, something at times dangerously near to it. It meant that trucks, which the Red Cross organization had purchased back in America and had fought to find cargo space for in the always overcrowded transports, sometimes were no more than unloaded before the army, with its prior rights and necessities, would commandeer them for its own purposes. It meant not only hard roads, with the dangers attendant upon worn-out highway surfaces and an overpress of terrific traffic, to say nothing of the real war-time danger of a bursting shell at any moment, but the lack of proper garage and repair facilities to undo the havoc that these wrought; which, further translated, meant added difficulties not only in getting repair parts but the men properly equipped to install them.

The American Red Cross in France had at all times enough expert organization genius to enable it to organize its motor transport service upon the most modern lines of standardization and efficiency. It lacked one thing, however - time. If it had had time it might easily have selected one, or at the most, two or three types of motor trucks or camionettes and one or two types of touring cars and so greatly cut down the stock of repair parts and tires necessary to keep on hand at all times. But time did not permit this sort of thing. Time pressed and so did the Germans, and it was necessary to purchase almost any sort of truck or car that was available and put it to work without delay.

The man problem was quite as acute as that of the material. Good drivers and good repair men were alike 
hard to find in a nation that was all but exhausting its man power in the desperate effort to hold back the invading host. As it was, many of the workers in the Red Cross's transportation department were discharged soldiers. A few of them were mutiles - men who had suffered permanent and terrible injuries in the defense of their country. And a wearer of the Croix de Guerre more than once drove an American Red Cross car or blew a forge at one of its repair garages. The man-power question was at all times a most perplexing one.

I have mentioned this phase of the problem of my own accord. Neither Major Osborne nor any of his staff have referred to it. Yet it is typical of the many difficult phases of the big transportation problem which was thrust upon them for immediate solution - and which was solved.

To get some real idea of the magnitude of this transportation problem, come back with me for a day into the Red Cross garages of Paris. We shall once again, as in war time, have to start in the early morning, not alone because of the many plants to be visited but also because we want to see the big four-ton and five-ton trucks come rolling out of the great Louis Blanc garage, close beside the Boulevard de la Villette at the easterly edge of the city. As its name might indicate it faces the ancient street of Louis Blanc, faces it and morning and night fills it with its energy and its enterprise. Fills it completely and never disorderly. For I have seen it in the early morning disgorge from 150 to 200 trucks from its stone-paved courtyard and receive them, or others, back at night with no more confusion than a well-drilled military company would show in leaving its barracks or an armory.

The stone-paved courtyard itself is interesting. It is a bit of old Paris - the yard of an ancient stable where carters coming into the city with their produce from the fat farms of the upper Seine Valley or the Marne might 
rest their steeds for a time. The old structures which look down upon the courtyard have done so for two or three or four centuries - perhaps even longer. The only outward evidence of modernity about the place is its steeltrussed roof, wide of span and set high aloft, like the great train shed of some huge railroad station, and the splendidly efficient great motor trueks themselves. How those old carters of the royalist days of France would have opened their eyes if they could have seen a five-ton truck of to-day, American built, in all probability the output of some machine shop upon or near the shores of Lake Erie. They are wonderful machines - alert, efficient, reliable. I do not wonder that when one of our motor-truck manufacturers from the central portion of the United States visited the Verdun citadel - just a few months before the ending of the war - the commandant of that triumphant fortress kissed him upon the cheeks and led him to decorations and a state banquet in his apartments sixty-five feet beneath the surface of the ground. There were several hundred of the manufacturer's three-ton camions in the outer courtyard of the fortress and it only took a slight brushing away of the dust and mud to show that they had been on the job, in faithfulness and strength, since 1914.

One does not, under ordinary circumstances at least, have to brush away much dust and mud to find the number plate of the Red Cross ear; for the Red Cross follows the method of the American and the British armies in insisting upon absolute cleanliness for its equipment. One of the briskest departments in the huge Louis Blanc ga rage is the paint shop, and the evidences of its energy are constantly in sight about the streets of Paris.

The energy of some of the other workshop departments of the garage are perhaps less in evidence upon the streets, yet if these departments were not measuring constantly to the fullness of their possibilities their failure would be evident to any one - in constant breakdowns of equipment. The fact that the trucks and touring cars alike 
have had so few complete breakdowns, despite the terribly difficult operating conditions, shows that the Red Cross repair shops have been very much on the job at all times.

They are complete shops. In them it is possible to take a huge camion completely apart even to removing the engine and the body from the chassis and the frame, in order that cylinders may be bored anew, piston rings refitted, and bearings entirely renewed. All this work and more has been done under emergency in less than three days.

Close beside this Red Cross truck garage in the Rue Louis Blanc is a hotel for the two or three hundred workers and drivers employed there. It is small, but very neat and comfortable and homelike, and is directly managed by the Red Cross. It gives housing facilities in a portion of Paris where it is not easy to find such. And the long hours of the chauffeurs in particular render it highly necessary that they have living accommodations close to their work.

From Louis Blanc we cross Paris in the longest direction and come to the so-called Buffalo Park, in Neuilly, just outside the gates of the city. Buffalo Park gains its name from the fact that it once was a part of the circus grounds wherein the unforgetable "Buffalo Bill" was wont to disport his redskins for the edification and eternal joy of Paris youth. To-day it is a simple enough inclosure, fenced in a high green-painted palisade, ingeniously fabricated from packing cases in which knockeddown motor cars were shipped from America and guarded by a Russian wolfhound who answers to the name of "Nellie." In the language of the French, "Nellie" functions. And functions, like most of her sex, awfully well. She respects khaki; but her enthusiasm and lack of judgment in regard to other forms of male habiliment has occasionally cost the Red Cross the price of a new pair of green corduroy trousers, always so dear to the heart of the peasant. 
Within the green-painted inclosure of Buffalo Park there stands a permanent, especially built, fireproof warehouse and office building, and at all times from 175 to 200 camionettes, or light ton or ton and a half trucks. It does not undertake much repair work, particularly of a heavy nature, but its great warehouse holds hundreds upon hundreds of tires (the variety of wheel sizes in unstandardized motor equipment is appalling) and tens of thousands of spare and repair parts. The entire big plant is lighted by its own electric generating plant. A big fourcylinder gasoline engine, taken from a Yankee truck which had its back hopelessly broken on the crowded road to Rheims, and bright and clean and efficient, was thus put to an economic and essential purpose.

The other large garage and repair shop of the Red Cross transportation department in Paris is situated at No. 79 Rue Langier, close to the plants in Neuilly, yet just within the fortifications. It was the first garage to be chosen, and one easily can see why Osborne and his fellows rejoiced over its selection; for it is one of the most modern and seemingly one of the most efficient buildings that I have seen in Paris - three stories in height and solidly framed in reënforced concrete. It houses each night some two hundred touring cars and has complete shops for the maintenance and repair of this great squadron of automobiles.

Up to the present moment I have only touched upon the use of touring cars for the American Red Cross in France. Yet I should like to venture the prediction that without these cars, the greater part of them of the simplest sort, our work over there would have lost from thirty to forty per cent of its effectiveness. It is useless to talk of train service in a land where passenger train service has been reduced to a minimum and then a considerable distance beyond. Remember that the few passenger trains that remain upon the French railways are 
fearfully and almost indecently crowded. Folk stand in their corridors for three hundred or four hundred miles at a time. For a Red Cross worker bound from point to point to be forced to use these trains constantly in the course of his or her work is not only a great tax upon the endurance but a fearful waste of time.

The same conditions which exist in the outer country are reflected in Paris. The subway, the omnibus, and the trolley systems of the city all but completely broke down in the final years of the war when man power depletion was at its very worst. The conditions of overcrowding upon these facilities at almost any hour were worse even than the overcrowding upon the transit lines in our metropolitan cities in the heaviest of their rush hours. To gain a real efficiency, therefore, it became absolutely necessary many times to transport Red Cross workers, when on business bent, in touring cars. And because there were at the height of the work some six thousand of these folk - five thousand in Paris alone - it became necessary to engage the services of a whole fleet of touring cars. Some seventy touring cars were assigned to the Paris district. With very few exceptions these were operated on a strictly taxicab basis, with the Red Cross headquarters in the Hotel Regina as an operating center. Here, at the door, sat a chief dispatcher, who upon presentation of a properly filled order, assigned a car; and assigned it and its fellows in the precise order in which they arrived at that central station. It was all simple and efficient and worked extremely well. In the course of an average day the chief dispatcher at the Regina handled from eighty to one hundred requests, for runs lasting from twenty minutes to an entire day.

In the latter part of January, 1919, I saw this Transportation Department bending to an emergency, and bending to it in a very typical American fashion. A strike of the subway employees spreading in part to those of the 
omnibuses and trolley lines, had all but completely crippled the badly broken-down transportation of the city. And not only was the Red Cross being greatly hampered, but the personnel was being put to inconvenience and discomfort that was not at all compatible with the Red Cross idea of proper treatment of its workers.

In this emergency the transportation department jumped in. It moved up to the front door of the Regina on the first night of the strike a whole brigade of heavy camions and a squad of omnibuses such as it uses in transferring officers and men on leave between the railroad terminals and its various hotels in Paris. These were quickly but carefully assigned to definite routes which corresponded in a fashion to those of the more important subway routes. Huge legible placards announced the destination of each of the buses or trucks - Porte Maillot, Denfert-Rochereau, Place de la Bastille - as the various instances might be. Definite announcement was made of the hours at which these trucks would return on the following morning to bring the workers back again. The strike was over in two days, but if had lasted two weeks it would have meant little difference to the Red Cross workers. Their organization had shown itself capable of taking full care of them.

We have drifted away, mentally at least, from the big touring-car garage at No. 79 Rue Langier. Yet before we get entirely away from it we will find that it pays us well to see its shops; great, complete affairs situated in a long wing which runs at right angles to the main structure, and which employ at almost all times from eighty to one hundred mechanics - blacksmiths, machinists, painters, even carpenters, among them. French and American workmen are employed together, but never in the same squad. That would be an achievement not easy of accomplishment.

"How do the two kinds of workmen mix?" we ask 


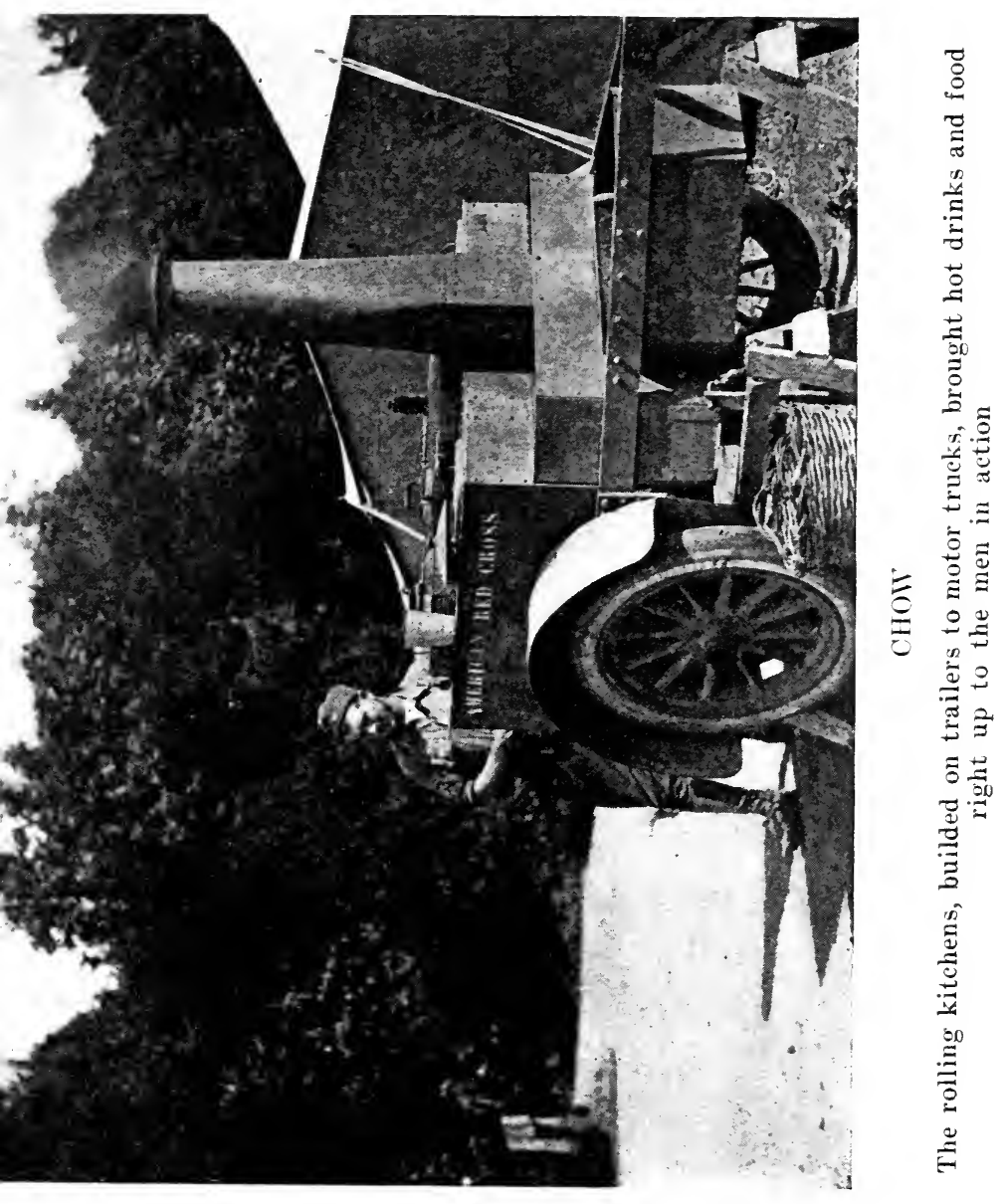



the young Red Cross captain in charge of the garage. $\mathrm{He}$ does not hesitate in his answer.

"The French are the more thorough workmen. They are slower, but their output is finer. The American gains the point more quickly and goes at it to achieve his end in a more direct fashion. Each is good in his own way. And each realizes the strong points of the other."

The Rue Langier garage keeps complete books for all four of the Paris Red Cross garages. We have seen three of them already, and inasmuch as the lunch hour approaches will prefer visiting the motor camp at Parc du Prince, just outside the fortifications and close to the Bois de Boulogne, used chiefly as an overflow park during the stiffest days of Red Cross activities. But in addition to this it does other things, not the least of them the maintenance of the transportation department's own post-office facilities and a clubroom for the use of the chauffeurs when they are off duty, not a very frequent occurrence.

"Do the chauffeurs ever play poker?" we ask Captain Conroy.

$\mathrm{He}$ assures us that they do not.

Also poker is supposedly interdicted at the big hotel which Major Osborne has established for the officers and men of his department out in Neuilly, just around the corner from Buffalo Park. There are plenty of other amusements to be found, however - books, games, cigars, cigarettes, a phonograph, and a remarkable cage of rare Oriental birds which, with pretty good success, at times try to silence the phonograph.

It is to this hotel that we find our way for lunch and, without hesitation, pronounce our meal the best we have had in Paris, which has more than a local reputation as a capital of good eating. We find an omelet souffé - the first to greet us in the town - roast turkey, mashed potatoes, Brussels sprouts, an American apple pie, bread 
and butter, and coffee with real creamy milk. And all for three francs! It is unbelievable. Our hotel charges us six francs for one pear - and an uncooked pear at that!

This remarkable hotel, which houses about two hundred of the transportation department workers, was one of Major Osborne's pet projects. It more than earned its modest cost in the promotion of the morale, and hence the efficiency, of his department. To its mess table, the major himself often came. Sometimes he brought his aid, Captain Hayes, out with him. Both confessed to a liking for roast turkey and omelet souffé. At the officers' table there was almost certain to be Captain Harry Taintor, a distinguished New York horseman, then at Buffalo Park and gaining experience in a distinctly different form of highway transportation; Captain M. D. Brown, also of Buffalo Park; Captain F. D. Ford, over from Rue Louis Blanc, and Captain Conroy from Rue Langier. These men and many others came to the hotel, and among them not to be forgotten a certain splendid physician who left a good practice up in Minnesota somewhere to come to Paris and look after the health and strength of the transportationdepartment personnel. More than sixty years young, no youngster in his twenties gave more freely or more unselfishly than this man. He was always at the service of his fellows in the Neuilly hotel.

His service was typical of the entire remarkable morale organization of the transportation department. It was the same sort of service that Miss Robinson, the capable manager of the hotel, forever was rendering, that the little supply shop across the street gave, that one found here and there everywhere within the department; a morale organization so varied and so complete that it might well stand for the entire American Red Cross organization in France, and yet served but one of the multifold activities of that organization. 
Before we have quite left the more purely mechanical phases of the transportation department - and lack of space or time will forbid my showing you the other important garage facilities in the outlying cities and towns of France - I want to call your attention to one important part of the problem, the supplying of fuel for the many hundreds of trucks and cars which the Red Cross operates throughout the French republic. You may have noticed at Buffalo Park one or two of the huge 7,500gallon trailer truaks used to bring gasoline from the United States Army oil station at Juilly, outside of Paris, to the Red Cross garages within the city.

In the months of its greatest activities, the Red Cross in France used an average of 25,000 gallons of gasoline. To have secured and transported this great quantity of oil even in normal, peaceful years would have been a real problem. To secure it, to say nothing of transporting it, in the hard years toward the end of the war, was a surpassing problem; for gasoline seemingly was the most precious of all the precious things in France. If you did not believe it, all you had to do was to ask a Paris taxi driver - even after taxis had become fairly plentiful once again upon the streets of the capital - to take you to distant Montmartre or Montparnasse - and then hear him curse Fate and lack of "essence" in his fuel reservoirs.

But the Red Cross, thanks to the French and American army authorities as well as to its own energies, did get the "essence." How it did it at times is a secret that only Osborne knows. And he probably never will tell.

Remember, if you will, that gasoline was the vitalizing fluid of the war; therefore, in France, it was guarded and conserved with a miser's care. For without it one knew that there could be little mobility of troops, little transport of supplies and ammunition, and no tanks or aëroplanes! Therefore every liter of it which came into France had to be accounted for. And in the years of fighting the private 
motor practically disappeared. Only the militarized car remained mobile and was permitted to retain access to the diminished gasoline stores of the Republic.

Throughout the entire nation, the French Army established gasoline supply stations. In its zones of special activity the American Expeditionary Forces had their own great stations in addition. On the presentation of a properly signed carnet or book of gas tickets, a military or Red Cross driver was permitted to obtain from any of these depots such an amount of gas or kerosene or lubricating oil as he might really need. The carnet slips were in triplicate, so that three records might be kept of the dispensation. No money was paid by the driver; his slip signed and delivered to the depot superintendent was sufficient. And by this method every gallon of gas so obtained was eventually paid for.

The basis of this entire plan was that a gallon of gasoline, no matter where it might be obtained, was a gallon of gasoline from the Allies' supply of the precious fluid and must not only be accounted for but paid for, in whatever way payment might be required. The French Government preferred to be paid in the precious fluid itself, liter for liter, as the Red Cross purchased it from the American Army. If it so happened, as it often did happen, that the restitution was made at a French port, although the original supply was drawn at depots many miles inland, the French were further compensated by the payment of a sum to represent the freight charges from that port to the distribution centers which supplied the depots. But for all the gasoline drawn from the American Army stores cash payment was made by the Red Cross.

To insure the conservation of the gas, the greatest care was used in choosing the men and women - for when we come to consider in detail the peculiarly valuable services rendered by the women personnel of the Red Cross in France, we shall find that more than once they mounted the driver's seat of a camion or touring car and remained 
there for long hours at a time - for drivers. And woe betide the man or woman caught wasting " essence." For when a driver left any of the garages with a car or camion - even if he were going but a short four blocks he carried with him a time-stamped ordre de mission indicating his destination. The quantity of gasoline either in the car's tanks or in the spare containers also was carefully registered. And if the driver should be discovered to have deviated from the shortest path between his garage and his destination he was called upon for an explanation. If this proved unsatisfactory he was warned for his first offense; for the next he went to a punitive period on the "wash rack" in the garage, which meant that from two or three days to two weeks or more he stepped down from the driver's seat and washed the dirty cars as they came in, and to the best of his ability, too. If discipline of this sort was found ineffectual, the culprit, being militarized as a member of the American Expeditionary Forces, was turned over to the provost marshal of the American Army in Paris for such punishment as he might see fit to impose. The latter might extend - and sometimes did extend - to deportation to America.

So far we have not even touched upon the dramatic phases of the work of the transportation function of our Red Cross. Yet do not for one moment imagine that it lacked these a-plenty. I said at the beginning of this chapter that the trucks and camionettes were not used for long hauls - ordinarily. It was far too wasteful and far too extravagant transportation. Yet, extraordinarily, these found their way the entire length and breadth of France. It might not be efficient or economical to ship beds and bedding in trucks; the food relief afforded by even a tightly packed five-ton camion was almost negligible save in a very great crisis. But think of the emergency possibilities of a truckload of surgical instruments rolling up to the battle line, or of five tons of ether finding its way 
to a field hospital all but overwhelmed by the inrush of wounded men. These were functions the transportation department could and did perform, and performed them so well as to merit the Croix de Guerre more than once for its men.

On one occasion, in particular, the drivers of a fleet of camions stood by the surgeons of a big field hospital as they performed operation after operation - each a trying mental strain, but performed apparently with no more effort than the simplest of mechanical processes. These boys - the most of them were hardly more than boys in that long forty-eight-hour trick were surgeons' helpers. They held the arms and legs that the scalpel severed and in the passing of but two days of their lives ceased to be boys and became case-hardened men.

How shall one best describe the really magnificent work of the Red Cross's efficient Transportation Department in such supreme emergencies as the last great drive of the Germans upon the western front; or in emergencies slightly smaller in area yet vastly important in the rôle they played to the rest of the war - such as the fearful explosion in the hand-grenade depot at $\mathrm{La}$ Courneuve, just outside of Paris, early in 1918? Of the work of the Red Cross in detail during the drive we have yet to read in other chapters of this volume. For three days after the La Courneuve disaster the French newspapers printed accounts of the American Red Cross work there, and every editorial writer in Paris paid his tribute to the promptness and courage with which that aid was given.

This explosion shook Paris, and the country roundabout for many miles, at a little before two o'clock in the afternoon. The force of the shock may be the better understood when one knows that it broke windows more than six miles distant from the hand-grenade depot. The Parisians thought at first that the boches had dared a daylight raid upon their city, but a great yellowish-gray cloud rising like a mighty column of smoke to the north quickly 
dispelled that notion. Only a mighty explosion could send such a beacon toward the heavens.

Major Osborne chanced to be at luncheon at the moment of the explosion. He jumped from the table and speeded to the main garage of the Red Cross in Paris as quickly as the nearest taxicab could take him; there he ordered five ambulances to be equipped and manned and held for orders. The superintendent of the motor division of the service also had seen that beacon, and he, too, had driven at top speed to the garage. The two men, with the aid of that beacon and a good map of the environs of Paris together with their knowledge of the war activities around about it, decided instantly that it must be La Courneuve that was the scene of the disaster, and without hesitation ordered the ambulances to hurry there.

"Hurry" to an ambulance driver! It was part of his gospel and his creed. In fifteen minutes the squad was at the smoking ruin, and the Red Cross, as usual, was the first ready to render help. It was needed; for although the death list was comparatively small - and one can say "Thank God!" for that - owing to the fact that the first of three thundering detonations had given the workmen a chance to run for their lives, practically all the houses in the near by communities had been shattered, and a great many folk wounded in their homes by falling walls and ceilings. The depot was ablaze when the Red Cross ambulances arrived, and from the center of the conflagration came the incessant bursting of grenades. Although pieces of metal were flying through the air with every explosion, the Red Cross workers went to the very edge of the fire, crawling on hands and knees over piles of hand grenades in search of the wounded. It was courage, courage of the finest sort; courage - I may say - of the Red Cross type.

On the morning of the twenty-second day of March, 1918, Parisians read in the newspapers that came with their matutinal coffee that the long-heralded and much-ad- 
vertised German drive was actually beginning. Major Osborne and his fellows saw those startling headlines. Instead of wasting time upon speculating as to what their final significance was to be, they interpreted them as a direct and personal call to duty. Within the hour they were at the big garage in the Rue Louis Blanc, realizing that the Transportation Department once again had an opportunity to demonstrate its real efficiency.

The drive was on; the pathetic and tragic seeming defeat of the allied forces begun. Retreat meant that refugees would soon be fleeing from the newly created danger areas, that there would be necessity for increased medical supplies for the rearward hospitals, and a vast amount of incidental work for both camions and men. The work of a transportation function in war is by no means limited to armies that are advancing or even stationary.

At Louis Blanc orders were given to make ready a battery of trucks at once to take on emergency supplies. Even while this was being done, a mud-spattered car came in from the danger zone with the news that important outlying towns were threatened and must be evacuated at once, that thousands of refugees already were falling back, and that the Red Cross warehouses must be stripped in order to prevent the precious stores from falling into the enemy's hands. Ten minutes later the telephone brought even more sinister news. In several villages close to the changing front, folk had been without food for twentyfour hours. Rations must go forward at once. Delay was not to be tolerated, not for a single instant.

Steadily the telephone jangled. Messengers by motor car or motor cycle came in to the transportation headquarters. Major Osborne made up his mind quickly. He is not of the sort that often hesitates. Within a half hour he was on his way toward the front in a car loaded with as many spare tires and tubes and gasoline as it could possibly carry, and headed straight for the little village of Roye. $\Lambda \mathrm{t}$ first it was possible to make a fair degree of 
speed; but as the front was neared the roads became congested with a vast traffic, so fearfully congested that the men in the relief car counted it as speed that they were able to make the seventy-five miles between Paris and Roye in an even three hours. Between Montdidier and Roye the highroads were all but impassable because of the press of the traffic - fleeing townsfolk and the movement of troops and artillery.

At an advanced Red Croșs post, Osborne began to get glimmerings of definite information. With them he set his course toward Noyon, eleven miles to the southeast. There was another Red Cross post there where he obtained full enough information to cause him to turn his car squarely around and begin a race against time to Paris. In less than two hours he was in his biggest garage there, drawing out trucks, giving definite orders, and beginning an actual and well-thought-out plan of relief. The story of the execution of that plan is best told in the words of the man who carefully supervised its details. Said he:

"There were six big trucks in the convoy that I took up to the front. We left Paris at midnight, the trucks loaded down with food and medical supplies and blankets. Although there was a great deal of movement on the roads, we plugged along all night without many delays and at five o'clock in the morning had to come to a dead stop. Artillery, transport camions, soldiers, and refugees blocked the way. We couldn't go a yard farther. Our orders were to go to $\mathrm{N}$ - with the supply stuff, but we couldn't have done it without an aëroplane. The army was moving, and the little space that it left in the roadway was occupied by the refugees. They came streaming back in every sort of conveyance or on foot, pushing their belongings in barrows and handcarts. Up ahead somewhere the guns were drumming in a long, ceaseless roll.

"As it was impossible to carrry out the original orders, the trucks were sent by crossroads to $\mathrm{A} \longrightarrow$, the nearest important point, and I went on in a little, light car to 
$\mathrm{N}-$, squeezing my way down the long, hurrying line of troops and transport. When I reached there, the railway station was under shell fire and all about it were British machine guns and gunners awaiting the Germans, who were even then on the outskirts of the town. The attack was being made in force and it was only a matter of a few more hours that the defenders could hope to hold out. They had mined all the bridges over the Oise and were ready to blow them up as they retreated.

"There was one Red Cross warehouse in $\mathrm{N}$ - and when I ran around to it I found that, very properly, the British and French troops had helped themselves from its stores. It was lucky they did, because the town fell into German hands that evening.

"With $\mathrm{N}$ - off the map, as it were, I speeded back to A - where there was a hospital in an old château. In this were sixty wounded American soldiers and about two hundred French. There were two American Army surgeons and a few French and English nurses. That afternoon we evacuated the Americans from the hospital, and made them all comfortable in their new lodgment at $\mathrm{C}$ After that we drove dack to $\mathrm{A}-$ and turned in, because we looked forward to a hard day. But at two o'clock in the morning a French general waked me up with the announcement that the Germans were advancing and that the hospital had to be completely evacuated in ten minutes. $\mathrm{He}$ made it very clear that it would have to be done in ten minutes, otherwise we'd find ourselves in No Man's Land. So I turned the men out and we went to work in the dark. As a matter of fact those ten minutes stretched from two o'clock until a little after six, when we carried out the last of the wounded. Some of them were in a bad way and had to be handled very slowly. We put them in our camions and took them ten kilometers to the Oise Canal, there transferred them to barges and thus they were conveyed to Paris.

"That left the hospital with only two American Army 
surgeons, the Red Cross personnel, and a French Army chaplain. The American surgeons looked about the place rather lonesomely, but one of them said he felt that something was going to happen and that before long there would be plenty of work for everybody. The guns thundering all around us seemed to bear him out.

"And he made no mistake! The very next afternoon several American Army ambulances arrived with loads of English and French wounded. They had been hurried down from the advanced dressing stations and a large percentage of them were in bad shape. Although we made only a handful of people, we hustled about and got the hospital going again somehow and started in to take care of the wounded. There were no nurses about the place, none in the town, because the civilians had been ordered out, so the drivers of the R'ed Cross camions offered their services. Two or three of them had been ambulance men at the front and knew a little something about handling wounded, but there wasn't one who had ever been a nurse! And the stiff part of it was so many of the wounded soldiers brought in were in such a condition that operation without delay was vital.

"When everything was made ready the two American surgeons started operating. They began at 7:30 o'clock in the evening and kept at it steadily until 3 o'clock in the morning. We - I say 'we' because every one had to do his bit - performed seventeen major operations, and every last one was successful! There wasn't a hitch in spite of all the difficulties of the job. In the first place only one set of instruments had been left behind. These had to be sterilized by pouring alcohol over them after they had been used for one operation so they'd be ready for the next. There wasn't time to boil them. And the light by which the surgeons worked was furnished by six candles stuck with their own wax to a board. I held the board. As the surgeon worked I moved it around so he might have the most light on the probing or cutting or sewing, or 
whatever it was he had to do. Three of the operations were trephining the skull. Another of the soldiers had fifty-nine pieces of shell in him, and every one of these was located and taken out by candlelight. It was a busy night! One lucky part of the business was that at midnight another American Army surgeon arrived and relieved at the operating table. The worst part of it was that the other worked so steadily that he knocked out most of the drivers and they couldn't give any help at all after a while, so that at last there were only two of us left to bear a hand.

"In the morning we succeeded in evacuating the hospital, taking the wounded to $\mathrm{C}-$, where there were ample facilities. And as soon as the wounded were carried from our trucks we were put to work getting out of the town the refugees who had accumulated there for several days. Then we turned to moving the Red Cross stores. $\mathrm{C}$ - was under air raid every clear night, so we had to sleep in the cellar of its great château. The bombs bursting all about the place made sleep almost impossible.

"And when this little bit of work was ended, the last of the refugees and their baggage transported to a neighboring railroad station, word came the Germans had dropped a .240 on a train at $\mathrm{R}-\mathrm{a}$ few kilometers away. So we hustled two camions over there and found four men killed and five wounded. We packed them into the trucks and brought them out, delivering the wounded to the hospital at C___ For two or three days we were busy in that neighborhood taking care of refugees, because they were streaming toward the haven of Paris by the thousands. Now and then we would get a call to go to such and such a point because a shell had killed people, or because stores had to be moved to more secure places. On one of these trips we met two men of an English lancers regiment who had been badly wounded and had ridden twenty kilometers in search of a base hospital. We picked them up, as this was one of our many appointed tasks, and 
took them to $\mathrm{C}$ - for treatment. They did not know what to do with their horses, and as there was no possibility of getting food for them every day, they debated whether to shoot them. They solved the problem by giving the two animals to me! And there isn't a doubt the creatures would have turned into elephants on my hands if I had not met a British battery on the road the next day. I offered the horses to the commander and he was overjoyed. ' I've lost eight horses already,' he explained, and hitched up my two and went rumbling off with his guns.

"In a little while the trucks were ordered to swing northward to S- The French had been there, but had retreated to straighten their lines, and at once the Germans began to shell the place. This eventually drove out the entire civilian population. It then became such a hot corner that it was no longer a billeting area for troops, and army camions were not allowed to pass through the city. But there was a Red Cross staff on the job there, and as it had been decided that no civilian relief was possible, the only task was to get out the staff and all the supplies it would be possible to move from the Red Cross warehouse.

"We went up with three camions, and as we entered the city we saw three big German sausage observation balloons watching the place and directing the gunfire. The boche guns were after some of the Aisne bridges, the railway station, or a big supply depot in the city. Within a short time after we got in, the shells began falling all around us. The savages had seen us, there wasn't any doubt of it. There had been no shelling of this place since the battle of the Aisne in 1915, but the Germans were making up for that.

"The Red Cross warehouse was in the chapel of the big seminary in the city, and while we were at work getting things out and loaded, the shells from the .240's came screaming in. The first one banged its way through a house directly across the street, and made a puff of dust of it, but as we were in the courtyard of the seminary we 
were protected from flying pieces. After that, at three and a half minute intervals by the watch, the firing continued. The second shell went over our chapel and exploded in an orchard fifty yards back of us. It showered us with mud, and a small piece of shell scored one of our fellows on the cheek. The third one the Germans sent over landed directly in the seminary garden. This was almost a bull'seye, so far as we were concerned, but we kept at it, making trip after trip, and when the last load left late in the afternoon, we had taken two hundred tons of precious supplies out of that warehouse and stored them several kilometers away.

"The last place on our list was hotter than any of the others, because the Germans were constantly changing their ranges and shelling everything in the back areas. We went to the little town of $\mathrm{M}$ - to bring out a Red Cross unit there which was at work only two kilometers in the rear of the French lines. We had no difficulty in getting the unit out, but when it came to getting the supplies, that was a different matter. We went up there with three cars and tried our best, but the shelling was too severe and we were ordered to come away. Nothing could have lived in that town the day we tried to make it.

"That's the little story of a week, and it was a full one. While the German guns were hunting out the important towns the French batteries were thundering back at them. And it seemed that everywhere we went the French guns came up, planted themselves, and went into action. In one town two .155's were towed in by gigantic tractors, stopped beside our trucks, and as soon as pits could be dug, began firing. Each gun fired four shots as quickly as possible and then the battery limbered up to the tractors and went on its way. I asked the commander why he didn't stay, because it seemed to me that a little protection wouldn't have been a half bad thing for us. He replied that as there was no camouflage possible in that town the guns had to be got away before they were spotted. He added that he 
was going on to the next town to fire four more shots, and then to still another one for the same purpose. He promised to come back to our little town soon, but I thanked him and said, "Never mind, we'll be gone by that time." "

And experience such as this was typical; not in the least unusual. And this, please remember, was the narrative of but one convoy; there were four others in that same sector, and in the same week, that had similar experiences. When we come to consider the Red Cross in its field activities with our army we shall hear other stories such as this ; for, of a truth, the work of the Transportation Department is eternally intermeshed and interwoven with that of American Red Cross relief service of every sort in France. Without transportation, little could ever have been done.

While convoys and relief supplies rushed toward the front, refugees found their way back from it. They came into Paris at the rate of nearly 5,000 a day and the American Red Cross was a large factor in taking care of them, of course. Their arrival at the railroad stations of the city gave the Transportation Department of the American Red Cross another task. All day, and day after day, its camions took food supplies to these terminals and afterward gathered the refugees and their baggage and bore them to other railroad stations and to the trains which were to carry them to their temporary destination.

"It was a busy week," laconically remarked a local Red Cross historian at that time.

These were but the beginnings of the days of real test of Major Osborne's department. For be it recorded that it was in the spring, the summer, and the fall of 1918 that the rush calls for Red Cross service came - and found its Transportation Department ready. We were just speaking of those doleful days of the March retreat, when things looked red and gray and black and misty before the eyes of those who stood for the salvation of the democracy of the world. We spoke in drama, now let us translate 
drama into cold statistics; understand quite fully that in the first thirty days of that March retreat, 162 truckloads of Red Cross supplies and materials were sent out on less than twelve hours' notice, 288 truckloads and material on twenty-four hours' notice, and 61 truckloads on fortyeight hours' notice; 511 loads in all. At one time, 35,000 front-line parcels were sent out within ten days.

And while these supplies were going out from headquarters, fifteen trucks were in continuous operation, evacuating the wounded along the routes from Noyon, Rivecourt, Resson, and Montdidier to Beauvais. And six rolling kitchens, operating in that selfsame territory, supplied hot food to the troops, which is typical of the work of the Red Cross Transportation Department in many similar territories. For instance, in that memorable year, in the attack on Pierrefonds, on July 29, word was received that several thousand wounded had been lying on the ground for two days. Twenty fully equipped ambulances went out at once and for seven days worked steadily evacuating the wounded, and all the while under constant fire. The entire section of ambulances went into service on seven hours' notice.

The Twenty-seventh Division - composed almost entirely of former members of the New York National Guard - did not hesitate, in emergency, to call upon our Red Cross. Major General John F. O'Ryan found that he was about to go into action and that less than fifty per cent of his army ambulance equipment was available. $\mathrm{He}$ turned to the Red Cross. Could it help him out with ambulances? Of course it could. That was part of its job - the big part, if you please - helping out in war emergencies. Twenty ambulances were immediately sent out from Paris, and during the attacks which took Le Catelet and Solenne, operated all the postes-de-secour of the Division.

There is still another phase of the Transportation De- 
partment, which as yet we have not even touched upon. I am referring now to the actual aid it lent the army with its vehicles from time to time. The Army War Risk Insurance Bureau, for instance, would not have been able to get about France at all if it had not been for twenty Red Cross cars. Its chief, Lieutenant Colonel Richard Cholmonley-Jones, so testified when he wrote to the American Red Cross heads in Paris, saying:

". . . I desire to express to the American Red Cross our deep appreciation of the assistance of the organization in our work. By furnishing motor transportation you enabled our field parties to reach the officers and enlisted men of the Expeditionary Forces, to place before them their opportunities under the War Risk Act. Our problem was, after all, a question of transportation. This you solved and I believe that in doing so you could have done no greater service, for you assisted in thus relieving these men of anxiety as to their families at home."

Nor was the aid of our Red Cross limited to the men of our army. It so happened that we had a navy overseas; and it was a real navy and filled with very real boys and men. It, too, came in for its full share of American Red Cross assistance. In fact, one of the larger camps of its aviation service was entirely constructed with the aid of Red Cross transportation.

At another time must be told the story of the work of the Transportation Department of our Red Cross in great bombing raids and cannonading which was inflicted upon Paris, week in and week out and month in and month out. It was part of its great chapter of assistance to the war-shocked population, civil and military, of all France. It is enough to say here and now that the problem was met with the same promptness, the same cheerfulness, and the same efficiency as characterized its work with our army and our navy. This huge portion of our Red Cross machine in France functioned - and functioned thoroughly. 


\section{CHAPTER V}

\section{THE AMERICAN RED CROSS AS A DEPARTMENT STORE}

FROM the Commissioner in Paris came this cablegram: can."

From the Washington headquarters was flashed this reply:

"Tents are on their way."

For the Red Cross it was all a part of the day's work. When Colonel Harvey D. Gibson, our Red Cross Commissioner in France in the latter half of 1918, found that the absolute limit for storage supplies in and around Paris had been reached and passed and that it would be several weeks at least before more additional warehouses could be constructed, his practical mind went at once to circus tents to meet the emergency. They would be rain-proof, sun-proof, frost-proof as well. And so, turning to the cable, he ordered the tents, as casually as he might have asked for 10,000 sweaters or 100,000 surgical dressings, and received them as he might have received the sweaters or the dressings, without an hour of unnecessary delay.

When we first came to consider the work of the Transportation Department of the American Red Cross in France, I spoke of the women who, with patriotic zeal directing both their minds and their deft, quick fingers, turned out the sweaters, the wristlets, the knitted helmets by not merely the tens, but by the hundreds of thousands. Their capacity - the united capacity of a land of some $20,000,000$ adult women workers - was vast. But the necessity was even more vast. And while the proportion of these creature comforts which were handmade and individual grew to great size, there also were vast quantities of 
these things and others which were purchased from manufacturers and in quantities which not only compelled these very manufacturers to turn over the entire output of their plants for many months but also compelled them to add to their factory capacity. And, of course, there were many things which the wives and mothers and sisters and sweethearts of America, with all their loving desires and keen capabilities, could not produce. Which meant that our Red Cross in France must have purchasing and warehousing functions - like big business of almost every other sort.

It would have been foolish and worse than foolish to have even attempted the problem without organization. That was the difficulty of the well-meaning American relief work which was launched upon French soil before the coming of our Red Cross. In the early days of the war the French ports were littered with boxes of relief supplies addressed "The American Embassy," "American Chamber of Commerce," "French Army," and just " France." People did so want to help, and so, in our impulsive American way, sent along things without sending any notice whatsoever as to whom they were to go. One of the big reasons for the foundation of the American Relief Clearing House was to combat this very tendency. As far back as October, 1914, it began by organizing French and American committees, obtaining freedom of customs for relief goods, free sea and rail freights, and finally, by organizing the War Relief Clearing House in New York, as a complementary committee for systematic collection and forwarding.

Eventually the Clearing House brought American donors to the point where they would actually mark the contents of boxes, but there was always great waste in not passing upon the serviceability of shipments until they had reached Paris and great delay in having to pack and re-sort them there. The secondhand material which came was of fair quality, but not sufficient in quantity. And while people here in the United States were always willing to 
contribute money generously they seemed disinclined to have goods bought outside this country. The result was that the American Relief Clearing House in Paris never had a sufficient accumulation against emergency. At the time of the first great offensive against Verdun, in the spring of 1916, it was compelled to send out all of the supplies which it held and to appeal to the United States for more clothes, food, and the like, which meant all of a six weeks' delay.

Such a state of things could not exist in our Red Cross work there. And yet the problem in this very phase that confronted Major Murphy and his party was tremendous. The Compagnie Générale Transatlantique had just notified the Clearing House that it could no longer afford to supply free space; and in view of the subsequent shipping situation, the heavy torpedoing, and the army demand for tonnage, it is considered not improbable that had the Clearing House continued it would have had to give up handling anything except money. Yet in spite of obstacles, the Red Cross would have to purchase and store supplies - not in the quantities that the Clearing Honse had purchased and stored them, but in far, far greater number.

Major Murphy met the problem squarely, as was his way. He cabled to America, and seven men were sent to him late in September, 1917. They were men taken from various corners of the country, but all of them expert in the task allotted to them. At once they began the work of coördinating the vast problem of American Red Cross purchase and supply. There was large need for them; for, while at the very beginning of our Red Cross work over there, while its problem, because of its vastness and its novelty, was still quite largely a question of guesswork, purchases were made for each department as it requisitioned material or was stored for them individually. Such a method was quickly outgrown, and was bound to be succeeded by a far better one, which, as we shall see presently, finally did come to pass. 
From the beginning the main warehouses, like the main garages, of the American Red Cross in France have been located in the headquarters city of Paris. Providing these facilities was one of the first tasks that confronted Major Murphy. And to understand the promptitude with which he met this task understand, if you will, that by the following September he already had six warehouses in Paris, organized with a capacity to handle 10,000 tons of supplies a month, which might quickly be increased to 60,000 tons a month. As a matter of fact, before Armistice Day was reached there were fourteen of these warehouses and they actually were handling some 10,000,000 tons a month.

The nucleus of this warehouse organization was again the American Relief Clearing House. It gave the first three of the store buildings. The next three were obtained by Major Murphy's organization, with the typical keenness of American business men who, having donated their services and their abilities to our great adventure overseas, purposed to make those services and abilities work to their highest possibilities.

Warehouses to be effective and efficient must have not only good locations, but appropriate railroad connections and modern equipment for handling their supplies; this is primary. The French, themselves, long since have recognized it as such. And because the freight terminal tracks at Paris are so abundant and so generally well planned there were plenty of warehouses there, if one could but find them. To find them was not so hard a task, even during the war, if one but had the time. There was the rub. The Red Cross did not have the time; there was not a day, not an hour, to be wasted. It needed storage space at once - ships with hundreds and thousands of tons of Red Cross relief supplies already were at the docks of French ports. More were on their way across the Atlantic. Space to store these cargoes must be found - and found immediately. By October 1, 1917, our Red Cross had twenty-one storage centers in France, giving it 5,000,000 
cubic feet of space as against but 50,000 three months earlier. The largest unit was a sugar warehouse in the wholesale center of Paris, a five-story stone structure with twelve hoists, two railroad tracks on the outside, and two within.

These facilities cost money, of course. And that in some instances they cost more money because time was a large factor in the question can hardly be denied. Yet economy was practiced as well as speed. This is record fact. Our Red Cross in France did not permit itself to become a waster; even in emergencies which called for a saving of time - no matter at what expense - it carefully watched the outgoing of dollars.

When, for instance, it sought to obtain one of the largest of its needed Parisian warehouses - a really huge structure with 2,500,000 cubic feet of storage space and served by two railroad tracks thrust into its very heart - it tried to drive a good Yankee bargain. The place had been found after a day of seemingly hopeless and heartless search. Its owner was located and the rental cost discussed briefly. The owner wanted ninety centimes (approximately seventeen cents) a square meter. The Red Cross agents demurred. They counter-offered with eighty centimes. The owner accepted.

"Shake!" said the chief of the party. They clasped hands.

"Never mind the formal papers now," laughed our Yankee Red Cross bargainer, "we'll take each other's word. I haven't a minute to lose, as we must have the place ready for supplies within forty-eight hours."

"Impossible!" cried the French landlord. He knew the real condition of the place, which had been unused and unrepaired for months.

Yet within forty-eight hours the Red Cross supplies from overseas actually were being moved in. Immediately upon closing the deal, the Americans had sought labor. It was 
not to be found, they were told; all the surplus labor of Paris being in the trenches or else engaged in some work vital to the war's operations.

"Why not use permissionnaires?" some one suggested.

The hint was a good one. It so happened that the French Government already had consented to the employment of this very sort of labor by the American Red Cross. So down to the larger railroad stations of Paris hurried our Red Cross agents. Soldiers back from the trenches were given the opportunity to earn a few francs - and gladly accepted it. Within a few hours a crew of more than a hundred men had been gathered and the work of making the newly acquired property ready to receive supplies begun. And under American supervision it was completed within the allotted two days.

This experience was repeated a few weeks later when the American Red Cross took over the old stables of the Compagnie Générale des Petites Voitures in the Rue Chemin du Vert as still another warehouse and had to clean and make them fit for supplies - all within a mere ten days. The Compagnie Générale des Petites Voitures was an ancient Parisian institution. It operated - of all the vehicles perhaps the most distinctive upon the streets of the great French capital - the little victoria-like fiacre, drawn by a wise and ancient horse with a bell about its neck. The war had drained the city of most of its horses - they were in the French artillery - and for a long time before the coming of our Red Cross the great stables in the Rue Chemin du Vert had been idle; in fact for the first time in more than half a century.

In taking over the place the officers of the American Red Cross were not blind to the fact that they were getting nothing more than a great, rambling, two-story stable and its yards, which were just as they had been left when a thousand horses had been led forth from their stalls. The place was a fearful litter of confusion, while crowded together 
at one end of the courtyard were the old fiacres - ancient, weather-beaten, decrepit, abandoned. They made a pathetic picture.

Rumor told the neighborhood, and told it quickly, that the Croix Rouge Américaine - as the French know our organization over there - had taken over the old stables and were to use them for warehousing purposes, but rumor was not smart enough to tell how the trick was to be done. It did not know; the Red Cross workers did. They had found after making a careful inventory of the place, that they had on their hands about 8,000 square yards of ground, covered for the greater part with more or less dilapidated buildings a hundred years old or even older. More than that, there were five hundred tons of manure in the structures which must be completely removed and the premises thoroughly disinfected before there could be even a thought of using them for goods storage. Cleaning the Augean stables was something of the same sort of a job.

Various Parisian contractors who specialize in that sort of work were asked what they would charge for the task of getting the big stables clean once again. One said seven thousand francs. Another allowed that it would cost five thousand. He was the lowest bidder. The Red Cross turned from all of them and went to the market gardeners of the great central Halles. Would they help? Of course they would - the name of the Croix Rouge Américaine has some real potency in France. In four days the stables were cleaned - perfectly and at an entire cost of less than two hundred francs!

Then, with the aid of a hundred workmen, the work of rehabilitating them was begun. At that time in Paris carpenters were not to be had for love or for money, so every available Red Cross man who knew how to saw a piece of wood or who could drive a nail without hitting his thumb - and at that, there were many thumbs jammed before the job was entirely done - was pressed into service. From the famous Latin Quarter of Paris came many volun- 
teers, some of them American painters and sculptors more familiar with working tools of other sorts, but all fired with a zeal and a determination to help. Such a prodigious din of work the neighborhood could not easily remember!

Lumber was scarce, almost unobtainable in fact. That did not discourage our Red Cross. One of the lesser buildings in the compound was quickly marked for destruction and actually was torn down in order to supply the lumber needed for the repair of the others. Windows were put in and glazed, doors were hung, wall derricks and hoistways rigged, roofs made water-tight, and the ancient cobbles of the courtyard scrubbed until they were almost blue in their faces. All the stables, the vehicle rooms, and the office quarters were disinfected, electric lights were installed in every corner, fire extinguishers hung throughout the buildings, telephones placed in each department, racks and bins for supplies constructed, lettered, and numbered, smooth cement walks laid to connect each building with its fellows - and not until all of this was done did the Red Cross men who had volunteered for the long hours of hard manual labor really dare stop for a deep breath.

"Talk about Hercules," laughed one of them when it was all done. "He had better lock to his old laurels. $\mathrm{He}$ never did a job like this - in ten days."

It took the folk of the neighborhood a long time to realize what had happened in ten days.

Yet there it was - if so you were pleased to call it one of the largest " retail-wholesale" stores in all Paris, with some 15,000 tons of supplies in place in the racks within a fortnight after the herculean and record-breaking cleansing task had been finished; and fresh stuff arriving daily to meet the needs of the hard-pressed peasantry and soldiers of France. And in a little time to perform similar service for the men of our own army and navy over there. Yet, unlike any other general store in the world wholesale or retail - this Red Cross one was open for business every hour of the day or the night. Comfortable 
quarters were prepared and furnished for six workers, who volunteered to live in the warehouse and so be prepared at any hour of the night to receive and execute an emergency call for supplies.

One huge task of this particular warehouse was the re-sorting of volunteer or donated shipments. From a period in the early progress of the war the Red Cross accepted only supplies shipped to its general stores - in no case whatsoever to individual organizations - and ordered that all goods should be sorted and re-packed in France for distribution there. So one big room in the Rue Chemin du Vert was turned over to this work. It never lacked variety. In one actual instance a big box sent from some city in the Middle West burst open and the first thing that met the gaze of the Red Cross warehouse workers was a white satin high-heeled party slipper poking its head out for a look at "gay Paree." And it was by no means the only tribute of this sort that thoughtless America gave to starving France. There sometimes were real opportunities for censorship in the re-sorting room.

A man who went to this great warehouse in the early days of its existence brought back a vivid picture of its activities.

"As one entered the long, wide courtyard through the great arch from the street - an arch, by the way, which reminded me wonderfully of the Washington Arch at the foot of Fifth Avenue, New York," said he, "and caught a glimpse of the flags of France and America - and the Red Cross - floating over it, he became immediately impressed with the militarylike activity of the entire place. This was heightened by the presence of a number of French soldiers and some fifty Algerians in their red fezzes, who were at work on crates and boxes. Three or four big gray camions were waiting at the upper end of the yard while the workmen loaded them. Opposite were what had once been the extensive stable structures, now clean and only 
reminiscent of their former tenants in the long line of chain halters hanging motionless against the walls. Here the bulkier, non-perishable goods were stored.

"Halfway up the entrance yard began the series of rooms whose shelves, fashioned ingeniously from packing cases, contained the great supplies of condensed milk, tobacco, sugar, soap, pork, canned beef, and rice. Overhead, on what was once the great hayloft of the stables, were the cubicles where were stacked the paper-wrapped bundles of new clothing for men, women, and children, every package marked with the size, and the sabots with thick wooden soles and the sturdy leathern uppers - enough to outfit a whole townful of people.

"Across a 'Bridge of Sighs' - the opportunity to call it that is quite too good to be lost - to another building, one came upon stores of chairs, bucksaws, farm implements, boxes of window glass, bedside tables, wicker reclining chairs, iron beds, mattresses, pillows, bolsters, blankets, sheets, pillowcases, and comforters. Through a wide doorway whose lintel was a rough hand-hewn beam as thick as a man's body and a century old, were the dormitory and the messroom of the red-fezzed Algerians who, by the way, were under the command of two French officers. Next came the lofts, with their bins of crutches, surgical dressings, rubber sheeting, absorbent cotton, enamel ware, bright copper sterilizers, and boxes of rubber gloves for hospital use. Still another building housed the immense supplies of wool gloves and socks, pajamas, sweaters, and women's and children's underwear and high stacks of brown corduroy jackets and trousers, for the Red Cross sought to furnish to the peasant just the same sort of clothing that he and his father's grandfather were accustomed to wear; even to the beloved béret.

"Throughout the storage building one came across evidences of the manner in which every available bit of old wood was utilized for reconstruction in order to avoid further expenditure. Bins and racks were made of ancient 
doors and window frames and crates had been carefully fashioned into delivery counters. In fact small 'branch stores' for the distribution of goods in less than box or crate lots were established in every corner of the Rue Chemin $d u$ Vert warehouse, with clerks always in attendance upon them. In this way it was as easy to fit out an individual with what he or she needed as to fit out an entire community, and the reverse.

"On the right side of the main courtyard, running back from the administration offices, were the long, narrow shipping rooms where the bundles called for were made up from the stock which lined the walls and were tagged and addressed by a corps of young women; the crate lots being attended to by the men in the courtyard below. Still farther on was the department which received the packages of used clothing, of knitted goods, or the other things sent by humane persons in countless cities of America and France to the needy ones in the fighting lines, or back of them. Below and beyond this room were the coal bins, the carpenter's shop, in which tables and bedside stands constantly were being turned out from new lumber, and the ' calaboose,' for the benefit of an occasionally recalcitrant Algerian. And adjoining the main courtyard was still another room almost as large; and this last was the place of receipt of all supplies. Here they were inspected, counted, and assigned to their proper buildings and compartments. The entire place was a great hive, literally a hive of industry. And the people of the neighborhood never passed its arched entrance without first stopping to look in, it all was so amazing to them. They wondered if there ever could have been a time when a thousand horses were stabled there."

Upon the day of the signing of the armistice and for many months thereafter Warehouse No. 1 in the Rue Chemin du Vert remained a busy hive of industry. It still handled almost every conceivable sort of commodity, and perhaps the only difference in its appearance from the 
day that the graphic New Yorker saw it was that German prisoners - each with a doggedly complacent look upon his face and a large "P. G." upon his back, - had replaced the Algerians for the hard manual labor. It continued to employ fifteen men and women in its office and from thirty-five to forty Red Cross workers, American or French, while the value of the stock constantly kept on hand was roughly estimated at close to $\$ 2,000,000$. From thirty-five to forty tons were daily being sent out. Yet how was a stock valuation of $\$ 2,000,000$ really to be compared with one of $\$ 2,500,000$ in warehouse No. 6 in the Rue Cambrai or $\$ 3,000,000$ at No. 24 in the Rue Curial? And these were but three of eleven Red Cross warehouses in Paris at the time of the armistice. And a report issued very soon after showed twenty-nine other warehouses of the American Red Cross in France, eight of them in the city of Dijon, which, because of its strategic railroad location, was a store center of greatest importance for our army over there.

Perhaps you like facts with your picture.

Well, then, returning from the picture of the thing to the fact, we find at the time of the first definite general organization of our Red Cross in France - in September, 1917 - a Bureau of Transportation and Supplies was formed under the direction of Mr. R. H. Sherman. A little later a slightly more comprehensive organization was charted, and a separate Bureau of Supplies created, with Mr. Joseph R. Swan as its immediate director. This was subdivided into four main sections: Paris Warehouses, Outside Warehouses, Receiving, and Shipping. This organization remained practically unchanged until the general reorganization plan of August, 1918, which we have already seen, when the bureau became the Section of Stores and, as such, a factor, and a mighty important factor, of the Division of Requirements.

From that time forward the problem was one of growth, great growth, rather than that of organization. It was a 
problem of finding warehouses to accommodate our supplies over there; of finding competent men to oversee and operate the warehouses, and then, in due order, of keeping the supplies moving through the warehouses and out to the men at the front. In due course we shall see how these supplies functioned. For the moment consider the fact that in an initiatory six weeks, from Octcber 11 to November 30, 1917, Mr. Swan submitted a detailed account showing how he had invested nearly $\$ 8,000,000$ in the purchase of general stores for our Red Cross. In the press of emergency work - there hardly was a month or a day from our arrival in France until after the signing of the armistice when the situation could not have been fairly described as emergency - it was possible to take but one general inventory. That was made, for accounting purposes, as of February 24, 1918, and showed the value of the American Red Cross stores then on hand in its warehouses in France to be $33,960,999.49$ francs, well over $\$ 6,000,000$. At the first of the following November - eleven days before the signing of the armistice - another inventory was taken. The stocks had grown. There were in the principal warehouses of the Red Cross alone and including its stock of coal upon the Quai de la Lorie supplies valued at 46,452,018.80 francs, or close to $\$ 9,000,000$. Figures are valuable when they mount to sizes such as these.

Yet figures cannot tell the way in which the warehousing organization of the American Red Cross met the constant emergencies which confronted it. Like the Transportation Department, it was forever and at all times on the job. For instance, from the beginning of that last German advance, in the Ides of March, 1918, until it was reaching its final fearful thrusts - late in June and early in July there was on hand, night and day, a crew at the warehouse, which had been fashioned from a former taxicab stables in the Rue Chemin du Vert, a complete crew to load camions by the dozens, by the hundreds, if necessary. In such a super-emergency no six men housed in the plant would do; 
for there were nights on which twenty, thirty, and even forty of the big camions went rolling out through that great archway with their supplies for our boys at the front - the very boys who so soon were to play their great part in the supreme victories of the war. On those summer nights warehouse work was speeded up, to put it very mildly indeed. Men worked long hours without rest and with but a single thought - the accomplishment of real endeavor while there yet remained time to save Paris and all the rest of France. And in such spirit is victory born.

Do not, I pray you, conceive the idea that all the warehouse work was done in Paris. I have hinted at the importance of Dijon, the great army store center, as a Red Cross stores center, and have, myself, stood in the great American Red Cross warehouse upon the lining of the inner harbor of St. Nazaire and have with mine own eyes seen 8,000 cases stacked under their capacious roofs - foodstuffs and clothing and comforts and hospital supplies which came forever and in a steady stream from the transports docking at that important American receiving point, and have known of warehouses to be established in strange quarters, stranger sometimes than the abandoned stables of the horse-drawn taxicabs of Paris, here in an ancient exposition building upon the outskirts of a sizable French city, there in a convent, and again in a church or a school, or even again in a stable.

Here was a little town, not many miles back from the northern front. The Red Cross determined to set up a warehouse there, both for military and civilian relief supplies. An agent from the Paris headquarters went up there to confer with the local representative in regard to the proper location for the plant. The local man favored one building, the Paris representative another which was nearer to the railroad station. While they argued as to the merits of the two buildings German airmen flew over the town and destroyed one of them. And before they 
could compromise on the other, the French Government requisitioned it as a barracks.

Now was a time for deep thought rather than compromise. And deep thought won - it always does. Deep thought moved the American Red Cross warehouse into the ancient seminary there, even though that sturdy structure had been pretty well peppered by the boche. When the Red Cross moved in, you still could count fifty-one distinct shell holes in it; another and a final one came while it still was in the process of adaptation to warehouse uses. In this badly battered structure lived the Red Cross warehouse man and his three assistants - all of them camion chauffeurs - after they had put forty-five panes of glass in with their own hands. Then the supply of glass ran out. In the former chapel of the seminary fourteen great window frames had to be covered with muslin, which served, after a fashion, to keep out the stress of weather. Twentyseven of the precious panes of glass went into the office where daylight was of the greatest necessity. The rest were used, in alternation with the muslin, for the living quarters, where the Red Cross men cooked their own meals, in the intervals between dealing out warehouse supplies. It was hard work, but the chauffeurs did not complain. Indeed it so happened that their chief did most of the complaining.

"What is the use?" he sputtered one afternoon while the war still was a day-by-day uncertainty. "Those boys will put in a big day's work, every one of them, come home and not know enough to go to bed. Like as not they will take a couple of hours and climb up some round knoll to watch the artillery fire. When the town was in the actual line of fire - not more than a fortnight ago - one of them turned up missing. He had been with us only a moment before, so we began hunting through the warehouse for him. Where do you suppose we found him? Let me tell you : he was up in the belfry, the biggest and the best target in the town. Said he wanted to see where the shells were 
striking. I told him to come down, the Red Cross wasn't paying him for damn foolishness. But you couldn't help liking the nerve of the boy, could you?"

\section{Courage!}

How it did run hand in hand with endeavor all through the progress of this war. And it was not limited to the men of the actual fighting forces. The Red Cross had more than its even share of it. The great, appealing roll of honor in the Hotel Regina headquarters - the list of the American Red Cross men and women who gave their lives in the service of their country - was mute evidence of this. Courage in full measure, and yet never with false heroics. Full of the sturdy everyday courage, the courage of the casual things, exemplified, for instance, in this letter from the files of the Stores Section, written by the agent in charge of another of its warehouses in northern France:

"A shipment of four rolls of oiled cloth arrived most opportunely a few days ago and one roll is being employed locally to repair the many panes of window glass destroyed in last night's air raid. In connection with this raid it may be added that one of our chauffeurs nearly figured as a victim of this raid, the window in his lodging being blown in and a large hole knocked in the roof of his house.

"I presume that it is violating no military secret to add that another raid from the boches is looked for to-night and in case it does come the other rolls of window cloth may come into play. ...."

It was in these very days of the great spring offensive of 1918, that the Supplies Department, like the Transportation Department of our Red Cross overseas, began to have its hardest tests. For in addition to the regular routine of its great warehousing function, there came, with the rapidly increasing number of troops, hospitals and refugees, rapidly increasing special duties for it to perform; greatly increased quantities of goods to be shipped. And 
I think it but fair to state that without the vision of one man, Major Field, there might not have been many supplies to ship. Immediately after his appointment as Chief of the Bureau of Supplies, Major Ficld began to purchase goods, in great quantities and an almost inconceivable variety. $\mathrm{He}$ bought in the French market, in the English market, in the Spanish market, from the commissary stores of the United States Army - in fact from every conceivable corner and source of supply; as well as from some which apparently were so remote as hardly to be even conceivable. He stored away beds, tents, sheets, clothing, toilet articles, and cases of groceries by the thousands, and still continued to buy. The Red Cross gasped. The A. E. F. protested. The vast warehouses were filled almost to the bursting point. Major Field listened to the protestations, then smiled, and went out, buying still more supplies. His smile was cryptic, and yet was not; it was the smile of confidence, the smile of serenity. And both confidence and serenity were justified. For the days of the drive showed - and showed conclusively - that if our American Red Cross had not been so well stocked in supplies it would have failed in the great mission overseas to which we had intrusted it.

"The — th Regiment has moved up beyond its baggage train. Can the Red Cross ship blankets and kits through to it?"

This was a typical emergency request - from an organization of three thousand men. It was answered in the typical fashion - with a full carload of blankets and other bedding. The kits followed in a truck.

"A field hospital is needed behind the new American lines," was another. It, too, was answered promptly; with several carloads of hospital equipment, surgical dressings, and drugs. These things sound simple, and were not. And the fact that they were many times multiplied added nothing to the simplicity of the situation. In fact there came a time when it was quite impossible to keep any exact 
account of the tonnage shipped, because the calls came so thick and fast and were so urgent that no one stopped for the usual requisitions but answered any reasonable demands. The requisition system could wait for a less critical time, and did.

One day a message came that a certain field hospital was out of ether - that its surgeons were actually performing painful operations upon conscious men - all because the army had run out of its stock of anæsthetics. The men at the American Red Cross supply headquarters sickened at the very thought; they moved heaven and earth to start a camion load of the precious ether through to the wounded men at the field hospital, and followed it up with twenty-five truckloads of other surgical supplies.

Under the reorganization of the American Red Cross in France which was effected under the Murnane plan, the entire work of purchase and warehousing was brought under a single Bureau of Supplies, which was ranked in turn as a Department of Supplies. This Bureau was promptly subdivided into two sections: that of Stores and that of Purchases. Taking them in the order set down in the official organization plan, we find that the headquarters section of Stores - situated in Paris - was charged with the operation of all central and port warehouses and their contents and was to be in a position to honor all properly approved requisitions from them, so far as was humanly possible. It was further charged to confer with the comptroller of our French American Red Cross organization and so to prepare proper system and check upon these supplies. In each of the nine zones there were to be subsections of stores, answerable for operation to the Zone Manager and for policy to the Paris headquarters, but so organized as to keep not only sufficient supplies for all the ordinary needs of the zones, but in various well-situated warehouses, enough for occasions of large emergency - and all within comparatively short haul. 
The Section of Purchases corresponded to the purchasing agent of a large corporation. Remember that the purchasing opportunities in France were extremely limited, so that by far the greater part of this work must be performed by the parent organization here in the United States, and sent - as were the circus tents - in response to requisitions, either by cable or by mail. Incidentally, however, remember that no small amount of purchasing for the benefit of our army and navy in France was done both in England and in Spain, which, in turn, was a relief to the overseas transport problem. For it must ever be remembered that the famous "bridge across the Atlantic" was at all times, until after the signing of the armistice at least, fearfully overcrowded. It was only the urgent necessities of the Red Cross and its supplies that made it successful in gaining the previous tonnage space east from New York, or Boston, or Newport News. And even then the tonnage was held to essentials; essentials whose absoluteness was almost a matter of affidavit.

Yet even the essentials ofttimes mounted high. Before me lies a copy of a cablegram sent from Paris to Washington early in January, 1919. It outlines in some detail the foodstuff needs of the American Red Cross in France for the next three months. Some of the larger items, in tons, follow:
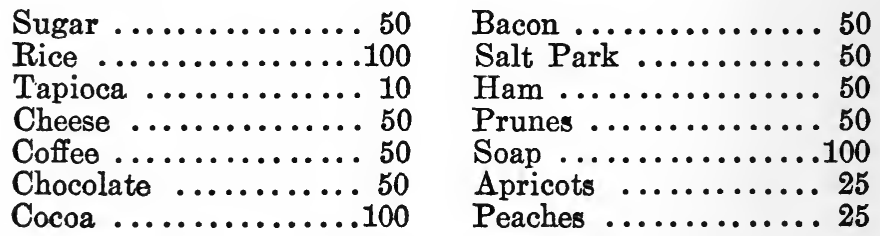

And all of this in addition to the 10,000 cases of evaporated milk, 5,000 of condensed milk, 3,000 of canned corn beef, 2,000 of canned tomatoes, 1,000 each of canned corn and oanned peas, and 1,000 gross of matches, while the 
quantities ordered even of such things as cloves and cinnamon and pepper and mustard ran to sizable amounts.

I have no desire to bore you with long columns or tables of figures - for this is the story of our Red Cross with our army in France and not a report. Yet, after all, some figures are impressive. And these given here are enough to show that of all the cogs and corners of the big machine, the Purchase and Stores sections of the organization in France had its full part to do. 


\section{CHAPTER VI}

THE DOUGHBOY MOVES TOWARD THE FRONT

B Y July, 1917, the first Divisions of our amazing army B began to seep into the battle countries of Europe. It had not been the intention of either our War Department or its general staff to send the army overseas until the first of 1918 ; the entire plan of organization and preparation here in the United States had been predicated upon such a program. Yet the situation overseas was dire indeed. Three years of warfare - and such warfare - had begun to fag even the indomitable spirits of England and of France. The debacle of Russia was ever before the eyes of these nations. In the words of their own leaders, their morale was at its lowest point. France, in one glorious moment in 1917, had seemed, under the leadership of Nivelle, to be close to the turning point toward victory. But she had seen herself miss the point, and was forced again in rugged doggedness to stand stoutly with England and hold the line for the democracy of the world.

In such an hour there was no opportunity for delay; not even for the slight delay incidental to raising an American Army of a mere half million, training it in the simplest possible fashion, and then dispatching it overseas. Such a method would have been more gratifying to our military pride. We sacrificed that pride, and shall never regret the hour of that decision. We first sent hospital detachments from our army medical service to be brigaded with the British, who seemed to have suffered their most severe losses in their hospital staffs, and sent engineer regiments not only to build the United States Military Railroad, of which you have already read, but also to aid the weakened land transport sections of the French and British armies. 


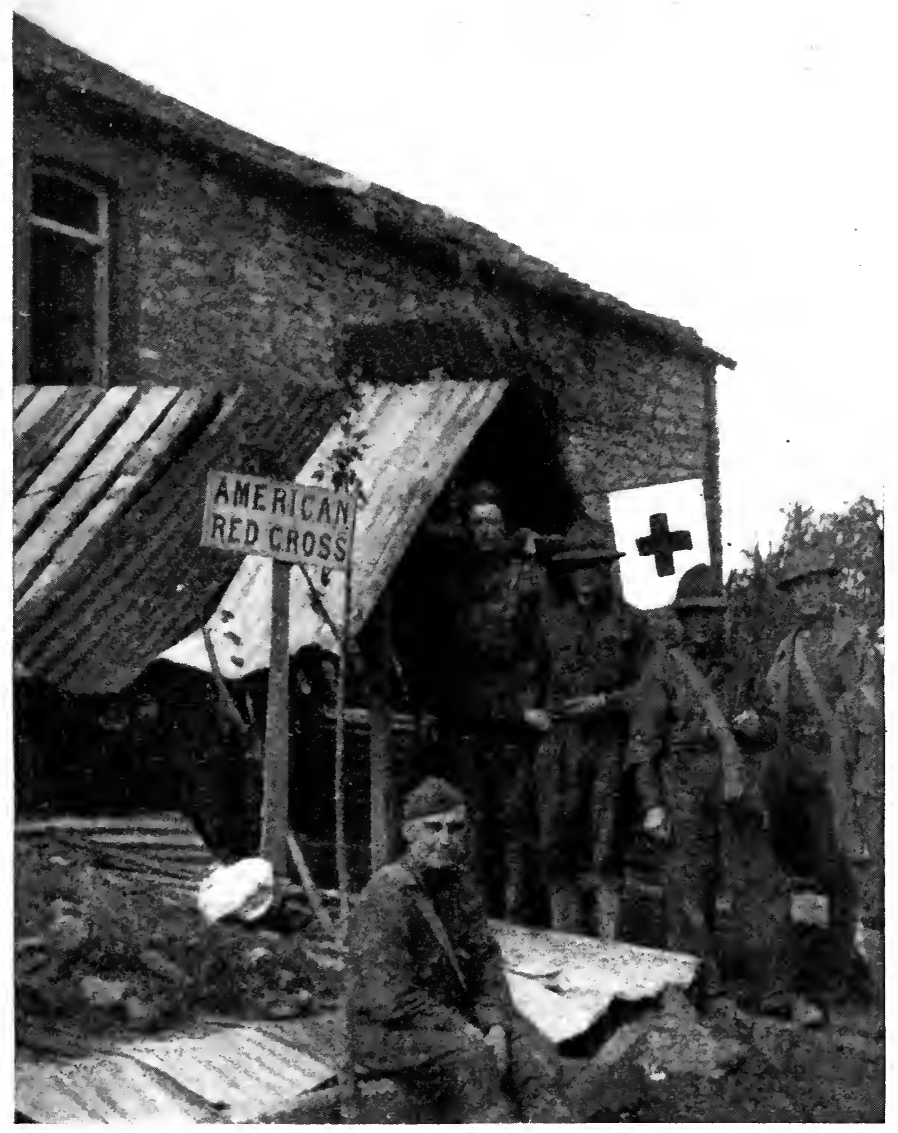

OER RED CROSS AT THE FRONT

A typical A. R. C. dugout just behind the lines 

And General John J. Pershing, with adequate staff assistance, crossed to Paris to prepare for the first and allglorious American campaign in Europe.

"The program had been carefully drawn up," wrote Lieutenant Colonel Repington, the distinguished British military critic, in a review on the performance of our army in the London Morning Post, of December 9, 1918. "It anticipated the orderly arrival in France of complete units, with all their services, guns, transport, and horses, and when these larger units had received a finishing course in France and had been trained up to concert pitch it was intended to put them into the line and build up a purely American Army as rapidly as possible. After studying the situation, the program and the available tonnage in those days, I did not expect that General Pershing could take the field with a trained army of accountable numbers much before the late summer or autumn of 1918."

Yet by the first day of January, 1918, there were already in France four American Divisions, each with an approximate strength of 28,153 men, by February there were six Divisions, and by March, eight. It is fair to say, however, that even by March only two of the Divisions were fit to be in the line, and none in the other active secters. Training for modern warfare is indeed an arduous task. Yet our amazing army did not shirk it, and even in the dispiriting and terrifying days of the spring of $1918 \mathrm{kept}$ to its task of preparing itself for the great ordeal just ahead, and, almost at the very hour that the last great German drive began to assume really serious proportions, was finishing those preparations. Ten Divisions were ready, before the spring was well advanced, to stand shoulder to shoulder with British Divisions should such an unusual course have been found indispensable. In fact, anticipating this very emergency, brigading with the British had already been begun. But as the British reinforcements began pouring into Northern France the possibilities of the emergency arising diminished. And five of 
our Divisions were returned south into the training camps of the United States Army.

The War Department figures of the size of our army in France throughout 1918 - which at the time could not be made public, because of military necessities - tell the story of its rapid growth. They show the number of Divisions in France and in line and in reserve to have been as follows:

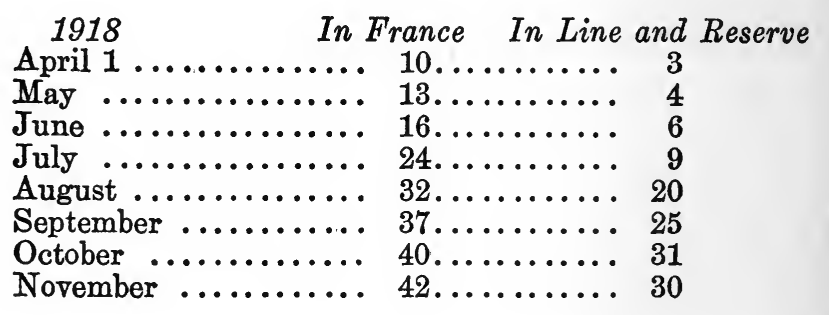

This tabulation takes no count whatsoever of the noncombatants of the S. O. S.- as the army man knows the Service of Supplies - or the other great numbers of men employed in the rearward service of the United States Army. It is perhaps enough to say that the largest number of our troops employed in France was on September 26, the day that General Pershing began his Meuse-Argonne offensive. On that day our army consisted of $1,224,720$ combatants and 493,764 noncombatants, a total of 1,718 ,484 men in its actual forces.

It is known now that if the war had continued we should probably have doubled those figures within a comparatively few months and should have had eighty Divisions in France by April, 1919, which would have made the United States Army by all odds the most considerable of any of the single belligerent nations fighting in France.

We have told elsewhere a little of the romance of the transport of our men; here in cold figures - statistics which scorn romance in their composition - is their result. We shall see through our Red Cross spectacles again and 
again the performances of that army, as the men and the women of the American Red Cross saw them.

In the meantime let us turn again, therefore, to Lieutenant Colonel Repington, whose reputation in this regard is well established, and find him saying of the commanding general of our army:

"To my mind, there is nothing finer in the war than the splendid good comradeship which General Pershing displayed throughout, and nothing more striking than the determined way in which he pursued the original American plan of making the American arms both respected and feared. The program of arrivals, speeded up and varied in response to the appeal of the Allies, involved him in appalling difficulties, from which the American army suffered to the last. His generous answer to cries for help in other sectors left him for long stretches almost, if not quite, without an army. He played the game like a man by his friends, but all the time with a singleness of purpose and a strength of character which history will applaud; he kept his eyes fixed on the great objective which he ultimately attained and silenced his detractors in attaining it. To his calm and steadfast spirit we owe much. To his staff, cool amidst the most disturbing events, impervious to panic, rapid in decision, and quick to act, the allied world owes a tribute. To his troops, what can we say? They were crusaders. They came to beat the Germans and they beat them soundly. They worthily maintained the tradition of their race. They fought and won for an idea."

Truer words have not been written. To one who has made even a superficial study of our army in France, the figure of the doughboy - the boy from the little home in Connecticut or Kansas or Oregon - looms large indeed. I did not, myself, see him in action. Other and abler pens have told and are still telling of his unselfishness, his audacity, his seemingly unbounded heroism both in the trenches and upon the open field of battle. The little rows 
of crosses in the shattered forest of the Argonne or upon the roads leading from Paris into Château-Thierry, elsewhere over the face of lovely France, tell the story of his sacrifice more graphically than any pen may ever tell it.

Frequently I have seen the doughboy in Paris as well as in the other cities and towns and in our military camps in France. He is an amusing fellow. One can hardly fail to like him. I have talked with him - by the dozens and by the hundreds. I have argued with him, for sometimes we have failed to agree. But I have never failed to sympathize, or to understand. Nor, as for that matter, to appreciate. No one who has seen the performance of our amazing army in France, or the immediate results of that performance, can fail to appreciate. If you are a finicky person you may easily see the defects that haste brought into the making of our expeditionary army - waste in material and in personnel here and there; but, after all, these very defects are almost inherent in any organization raised to meet a supreme emergency, and they appear picayune indeed when one places them alongside the marvel of its performance - when one thinks of Château-Thierry or Saint Mihiel or the Argonne.

It is not the province of this book to describe the operations of our army in France except in so far as they were touched directly by the operations of our Red Cross over there. So, back to our text. You will recall that Major Grayson M.-P. Murphy, our first Red Cross Commissioner to France, and his staff arrived in Paris coincidently with General Pershing on the thirteenth of June, 1917. They went right to work, despite terrific odds, in the building of a working organization. At about. the hour of their coming there was developing here in the United States a rather distinct feeling in certain widespread religious and philanthropic organizations that they should be distinctly represented in our war enterprise in Europe. The patriotism that stirred these great organ- 
izations was admirable; it was unmistakable, and finally resulted in certain of the larger ones - the Young Men's Christian Association, the Knights of Columbus, the Young Women's Christian Association and the Salvation Army being given definite status in the war work overseas. In the case of the Y. M. C. A.- - by far the largest of all these organizations - it was allotted the major problem of providing entertainment for the enlisted men and the officers at the camps in France, in England, in Italy and, in due time, in the German valley of the Rhine. At a later hour the very difficult problem of providing canteens, that would be, in effect, nothing more nor less than huge post exchanges, was thrust upon the Y. M. C. A. It accepted the problem - not gladly, but in patriotic spirit - and even though the experiment brought upon its shoulders much thoughtless and bitter criticism, saw it bravely through.

The Y. M. C. A. therefore, was to undertake, speaking by and large, the canteen problem of the camps, while that of the hospitals, the docks at the ports of debarkation and embarkation, the railroad junctions, and the cities of France was handed to the American Red Cross. The Red Cross began its preparations for this particular part of its task by establishing stations for the French Army, which, pending the arrival of the American forces, would serve admirably as experiment stations. Major Murphy at once conferred with the French military authorities and, after finding from them where their greatest need lay, proceeded without delay to the establishment of model canteens on the French lines of communication; in the metropolitan zone of Paris and at the front. And before our army came, and the great bulk of the work of our Red Cross naturally shifted to it, these early canteens supplied rations to literally millions of French soldiers.

"In view of keeping up the good spirits of troops it is indispensable that soldiers on leave be able to find, while waiting at railroad stations in the course of their journeys, 
canteens which will allow them to have comfortable rest and refreshment. Good results have already been obtained in this direction, but it is necessary to improve the canteens already existing and to create new ones in stations that do not already have them."

The above is a translation of a quotation from a note written by the French Minister of War to a general of his army, at about the time of our first Red Cross Commission over there. If one were to attempt to translate between the lines he would be certain to find that the soldiers going home on leave or discharge, obliged to wait long hours in railroad stations, sometimes without food or other comforts, and ofttimes, too, forced to sleep upon a cold, stoneflagged floor, had often a greatly lowered morale as the result of such an experience. And if their mental state was not lowered, their physical condition was almost sure to be.

So it was that the American Red Cross jumped into the immediate assistance of its rather badly burdened French brothers - the various organizations of Croix Rouge Française. It seized as its most immediate opportunity, Paris, and particularly the junction points of the Grande Ceinture, the belt-line railroad which completely encircles the outer environs of the city, and provides track-interchange facilities for the various trunk-line railroads which enter her walls from every direction. For lack of funds and a lack of personnel the French Red Cross authorities were about to close some of the canteens which they already had established upon the Grande Ceinture, while the real necessity was that more should be opened. Such a disaster our American Red Cross prevented. On July 18, 1917, Colonel Payot, Director of the French Army Transports, wrote to H. H. Harjes - at that time representative of the American Red Cross at the general headquarters of the French Army - giving a list of railroad stations where canteens were needed, and in the order of their urgency. In the correspondence which followed between the French authorities 
and the American Red Cross, various agreements were reached.

It was agreed that the French administration would furnish the necessary buildings and provide electric light, running water, and coal for heating. On the other hand, the American Red Cross undertook to furnish all other supplies - cooking appliances, coal for cooking, equipment, stores, medical supplies, and personnel. As early as July 31, Major Perkins wrote that our American Red Cross was now ready to serve a full meal at seventy-five centimes (fourteen or fifteen cents) a person, and other drinks and dishes at small cost to the poilu. Men without funds on receiving a voucher from the Commissaire de la Gare (railroad-station agent) could obtain meals and hot drinks without charge. The sale of wine, beer, and spirits was prohibited in our canteens. And because of the French coöperation in their establishment, they were named Les Contines des Deux Drapeaux and bore signs showing both the Tricolor of France and our own Stars and Stripes, with their designating name beneath.

The original list of outside stations suggested by the French authorites were five in number: Pont d'Oye, Châlons, Epernay, Belfort, and Bar-le-Duc. Finally it was decided to reduce this list - the hour of the arrival of the American forces in number steadily drawing nearer - and Châlons and Epernay were definitely chosen for American Red Cross canteen work. At that time both of these cities of the Champagne district were well behind the lines; afterwards the Germans came too close for comfort and shelled them badly, which meant the withdrawal of the French troops and a closing of the neat canteens for a time; but they were reopened. When I visited Epernay in January 1919, the Red Cross canteen there was again open and in charge of two young ladies from Watertown, N. Y. - the Misses Emma and Kate Lansing, sisters of the then Secre tary of State. You could not keep down the buoyant spiri of our Red Cross. 
Before the American Red Cross undertook to establish fully equipped canteens - on the scale of those at Châlons and at Epernay - the London Committee of the French Red Cross had been operating at many railroad stations small canteens known as the Gouttes de Café, where coffee and bouillon were served free to the soldiers in passing trains. In several cases agreements were made with the French society by which certain individual Gouttes de Café passed to the control of the American Red Cross and were, in other cases, absorbed in the larger installation which it was prepared to support. This, however, took place only when the demands of the situation really called for a larger canteen, prepared to serve full meals and operate dormitories and a recreation room. Occasionally it was found advisable for our Red Cross to inaugurate a canteen of its very own, while the Goutte de Café continued to carry on its own work on the station platform or in the immediate vicinity.

I remember particularly the situation in the great central station of the Midi Railroad in Bordeaux. This huge structure is a real focal point of passenger traffic. From beneath its expansive train shed trains come and go; to and from Paris and Boulogne and Biarritz and Marseilles and many other points - over the busy lines, not only of the Midi, but of the Paris-Orleans and the Etat. A great proportion of this traffic is military, and long ago the French Red Cross sought to accommodate this with a huge Goutte de Café in a barnlike sort of room in the main station structure and opening direct upon its platforms. I glanced at this place. It was gloomy and ill-lighted by the uncertain, even though dazzling, glow of one or two electric arc lights. It was fearfully overcrowded. Poilus occupied each of the many seats in the room and flowed over to the floor, where they sat or reclined as best they might on the benches or on their luggage. The place was illventilated, too. It was not one that offered large appeal.

How different the appearance of the canteen of our own 
Red Cross. It had a far less advantageous location; well cutside the station train shed and only to be found by one who was definitely directed to it. Two buildings had been erected and another adapted for the canteen. They were plain enough outside, but inside they were typically American - which meant that light and color and warmth had been combined effectively to produce the effect of a home that might have been in Maine, or Ohio, or Colorado, or California, or any other nice corner of the old U. S. A. There was homelike atmosphere, too, in the long, low buildings enhanced by the unforgetable aroma of coffee being made - being made American style, if you please. That building boasted a long counter, and upon the counter miniature mountains of ham sandwiches and big brown doughnuts - sandwiches and doughnuts which actually had been fabricated from white flour - and ham sandwiches with a genuine flavor to them. And all in great quantity - 2,000 meals in a single day was no unusual order - and for a price that was nominal, to put it lightly.

In another building there were more of the lights and the warm yellows and greens of good taste in decoration; a big piano with a doughboy at it some twenty-three hours out of the twenty-four - whole companies of divans and regiments of easy-chairs: American newspapers, many weekly publications, a lot of magazines, and books in profusion. The room was completely filled, but somehow one did not gain the sensation of its being crowded. The feeling that one carried from the place was that a bit of the U. S. A. had been set right down there at the corner of the great and busy chief railway terminal of the French city of Bordeaux. Only one forgot Bordeaux.

What was done at Bordeaux - and also at St. Nazaire and Nantes and Brest and Tours and Toul and many, many other points - by our Red Cross in the provision of canteen facilities was repeated in Paris, only on a far larger scale than at any other point. The A. R. C. L. O. C. 
canteens in Paris - there seems to be no holding in check that army passion for initialization - soon after the signing of the armistice had reached fourteen in number, of which about half were located in or close to the great railroad passenger terminals of the city. The others were hotels, large or small, devoted in particular to the housing of the doughboy and his officers on the occasions of their leaves to the capital - for no other point in France, not even the attractions of Biarritz or the sunny Riviera, can ever quite fill the place in the heart of the man in khaki that Paris, with all her refinements and her infinite variety of amusements, long since attained. These last canteens we shall consider in greater detail when we come to find our doughboy on leave. For the present we are seeing him still bound for the front, the war still in action, the great adventure still ahead.

A single glance at the records of the organization of the Army and Navy Department under which the canteen work along the lines of communication is grouped at the Paris headquarters of the American Red Cross, shows that it was not until February, 1918, that the inrush of the American Army in France had assumed proportions ample enough to demand a segregation of canteen accommodations for it from those offered to the poilus. As I have said, the canteens for the poilus were in the general nature of training or experimental stations for our really big canteen job over there, and as such more than justified the trouble or the cost; which does not take into the reckoning the valuable service which they rendered the blue-clad soldiers of our great and loyal friend - the French Republic.

Take Châlons, for instance: Châlons set an American Red Cross standard for canteens, particularly for such canteens as would have to take care of the physical needs and comforts of soldiers, perhaps in great numbers. This early Red Cross station was set in a large barracks some fifty yards distant from the chief railroad terminal of that busy town. And, as it often happened that the leave per- 
mits of the poilus did not permit them to go into the town, a fenced passage, with a sentinel, was builded from the train platforms to the canteen entrance. At that entrance, a coat room where the soldier could check his bulky kit was established.

On going into the restaurant of the canteen one quickly discovered that what might otherwise have been a dull and dreary barracks' interior had been transformed by French artists - the French have a marvelous knack for doing this very sort of thing - into a light, cheerful, and amusing room. The effect on the poilus who visited it for the first time was instantaneous; they had not been used to that sort of thing.

At one end of the gay and happy room was the counter from which the meals were served by the American women working in the canteen. The soldier went first to the cashier and from her bought either a ticket for a complete meal, or for any special dish that might appeal to his fancy or to his jaded appetite. He then went to the counter, was handed his food on a tray, and took it to one of the clean, white-tiled tables that lined the room. Groups of friends might gather at a table. But no one was long alone, unless he chose to be. Friendships are made quickly in the spirit of such a place, and the chatter and laughter that pervaded it reflected the gayety of its decorations.

After eating, if it was still summer, the poilu might stroll in the garden where there were seats, a pergola, even a Punch and Judy Theater - for your Frenchman, be he Parisian or peasant, dearly loves his guignol — or he might find his way to the recreation room, where there were writing materials, games, magazines, lounging chairs, a piano and a victrola. Here men might group around the piano and sing to their hearts' content. And here the popularity of Madelon was quite unquestioned.

And after all of this was done, he might retire to the dormitories with absolute assurance that he would be called in full time for his train - whether that train left at one 
o'clock in the morning or at four. And if he so chose, in the morning might refresh himself in the fully equipped washrooms, shower baths, or the barber shop, have his eoffee and eggs, his fruit and his beloved confiture and go aboard the train in the full spirit of a man at complete peace with the world.

The orders that came in February, 1918, calling for the segregation of the accommodations for the A. E. F. from those given to the French, did not result in withdrawing financial support from Châlons and the other canteens which our Red Cross had established particularly for the poilus, but did result in the establishment of rest stations, or canteens, exelusively for our own men. This organization of canteens extended particularly along the lines of communication between the area of action and the Service of Supplies zone, and was quite distinet from the canteen organizations at the ports and the evacuation hospitals; these last we shall come to consider when we see the part played by our Red Cross in the entire hospital program of the A. E. F. The Lines of Communication task was a real job in itself.

One could hardly rub the side of a magic lamp and have a completely equipped canteen materialize as the fulfillment of a wish. Magic lamps have not been particularly numerous in France these last few years. If they had been France might have been spared at least some of her great burden of sorrow. And so, even for our resourceful Red Cross, buildings could not always be provided, nor chairs, nor counters, nor even stoves. That is why at Vierzon, a little but a very busy railroad junction near Nevers, there was, for many months, only a tent. But for each dawn of all those months there was the cheering aroma of fresh coffee steaming up into the air from six marmites, as the French know our giant coffee containers. And the figures of American girls could be seen silhouetted against the glow of bonfires, while the line of soldiers, cups in 
hand, which started at that early hour, would continue for at least another eighteen, or until well after midnight.

Remember, if you will, that making coffee for a canteen is not making it for a household dining room. One does not measure it by teaspoonfuls. It is an affair of pounds and of gallons. The water - ten gallons for each marmite - was procured from a well which had been tested and adjudged pure. The sandwiches, with their fillings of meat or of jelly, were not the dainty morsels which women crumble between their fingers at bridge parties. They were sandwiches fit for fighting men. They were the sort that hungry soldiers could grip with their teeth.

Because of the necessary secrecy in reference to the exact numbers of passing troops, in turn because of military necessities, the American Red Cross was not permitted during the war to keep an exact record of the number of men who visited its canteens. But where hundreds were accommodated, even at as comparatively small a place as Vierzon, thousands were fed at the larger places, such as Dijon or Toul, for instance. And it is to be noted that in all these canteens food was being served to regular detachments of the A. E. F. as well as to easuals leaving or rejoining their commands.

In the great September drive of 1918 a canteen was set up by the roadside at Souilly. Night and day and without intermission it was maintained. It was there that stretcher bearers and ambulance drivers were given hot drinks and warm food - all that they wanted of both and where sometimes they toppled over from sheer fatigue and wearied nerves. From this one tent - and this is but one instance typical of many, many others - three hundred gallons of chocolate were served daily. And while bread was procured with the utmost difficulty, no boy was turned away hungry. Many times the snacks of food so offered were, according to the statements of the soldiers themselves, the first food that they had received for three days. 
And whether the canteen of our Red Cross was in a tent or a pine structure with splintery and badly put together walls, or, as ofttimes it was, in the corner of a baggage room of a railroad station, an attempt was always made to beautify it. We learned several things from the French since first we moved a part of America into their beloved land, and this was one of them. The example of the Châlons canteen was not lost. There is a psychological effect in decorative beauty that is quite unmistakable; translated it has a definite and very real effect upon that important thing that all really great army generals of to-day know as morale. It was the desire for good morale, therefore, that prompted the women of our Red Cross to decorate their canteens. And because skilled decorative artists were not always at hand, as they were as Châlons, makeshifts - ingenious ones at that - were often used. Magazine covers could be fashioned into mighty fine wall posters. In some instances, camouflage artists and their varied paint pots were called into service. For window curtains materials of gay colors were always chosen and, wherever it was possible, the lights were covered with fancy shades, designed according to the individual taste or the ingenuity of some worker.

Pianos were dug out of ruined houses or were even brought from captured German dugouts. A boche piano served as well as any other for the "jazz" which we took to poor France from the United States. The pianos in these Red Cross canteens hardly would have passed muster for a formal concert. But that did not matter much. It mattered not that they had the toothless look of old age about them, where the ivory keys had been lost; they were still something which a homeless Yankee boy might play - where he might still build for himself a bridge of favorite tunes right back into the heart of his own beloved home.

At Issoudon, the canteen reached an ideal of organization not always possible in some more isolated spots. At 
that point there was a mess for officers, a canteen for enlisted men, and clubrooms with books and the like for both. Moreover, a resthouse was inaugurated for officers and men by the Red Cross for the accommodation of those who stayed there overnight or even for a considerable number of hours. Eventually this last project was absorbed by the army, which took it under its direct control. The army knew a good thing when it saw it. The Issoudon resthouse was a good thing. It served as a model for a much more elaborate scheme of entertainment for our khakicoated men which, at a later time, was established by the American Red Cross in Paris. And which - so far at least as the officers were concerned - also was taken over by the army.

"A piece of fairyland" was the name that a doughboy with a touch of sentiment gave to the canteen at Nevers. A gardener's lodge attached to a château was loaned the American Red Cross by a titled and generous lady. It possessed a "living room" and a dining room that needed few changes, even of a decorative order. Upon the veranda, which commanded a view of a gentle and seemingly perennial garden, were many easy-chairs, while somewhere among these same hardy flowers was builded a temporary barracks for the housing of casuals and for shower baths for the cleanly comfort of the guests.

In the course of my own travels through the Red Cross areas in Europe I came to another canteen center other than that of the Bordeaux district, which still clings to my memory. I am referring to Toul, that ancient walled city of eastern France which has been a great fortress for so many centuries that mortal man seems fairly to have lost count of them. Few doughboys there are who traveled at all across the land of the lilies who can easily forget Toul that grim American army headquarters close by its stone walls and ancient gates, a marais of tight-set buildings and narrow stone-paved streets and encircled by a row 
of hills, which bore a row of fortresses. If the line had failed to hold at Verdun or at Pont-à-Mousson, Toul would certainly have become the next great battle ground, another gray city for which men might give their short lives in order that it might continue its long one.

This "if" was not realized - thank God for that! And the French, with their real generosity, realizing that the American headquarters in their eastern territory must be a city of great accessibility and real military strategic importance, quickly tendered Toul, which was accepted by our army in the same generous spirit in which it was offered by our Allies.

With Toul settled as a military center the problem of the Red Cross in connection with it at once became definite and important. It, of course, demanded immediate as well as entirely comprehensive solution. And that it had both was due very largely to the efforts of one woman, Miss Mary Vail Andress, of New York.

Miss Andress, who was one of the very first group of women to be sent by our Red Cross to France, arriving there August 24, 1917, came to Toul in January, 1918, Captain Hugh Pritchitt, who had been assigned to the command of the American Red Cross work at that American Army headquarters point, already of great and growing importance, had preceded her there by but four days, yet had already succeeded in making a definite survey of the entire situation. Out of that survey, and the more extended knowledge of the problem that came to the Red Cross folk as they studied it in its details, came the big canteen activities. For before the American Red Cross had been in the ancient French town a full fortnight, the men of the American Expeditionary Forces began pouring through it in great numbers. It takes only a single glance at the map to realize the reason why; for to the east of Toul are Nancy, Pont-à-Mousson, and the Lorraine line, while to the north and even a little to the west one finds Saint Mihiel, Verdun, St. Menehold, and the Argonne - places that already 
are household names all the way across America, while from Toul to the south and west, even unto the blue waters of the Atlantic, stretch the main stems of the United States Military Railroad in France - that remarkable railroad which, as you already know, really is no railroad whatsover.

So do not wonder that at the ancient railway station just north of the town walls and contiguous to the well-traveled Route de Paris, 1918 saw more and more of the long special trains stopping and debouching boys in khaki - hungry boys, thirsty boys, tired and dirty boys, and no provision for the relief of any of these ordinary human miseries.

It was a real situation, and as such the New York woman in the steel gray Red Cross uniform quickly sensed it. She moved toward its solution; which was easier said than done. For one thing the Red Cross chiefs in Paris, considering the thing judiciously from long range, were not at all sure of its practicability. But Miss Andress had no doubts, and so persisted at Paris until Paris yielded and permission was granted her to start a small canteen; yet this was only the first step in the solution of her problem. A second and even greater one was the securing of a location for canteen facilities. The meager facilities of Toul, selected as the field headquarters of an American Army, had been all but swamped by the fearful demands made upon them. Yet Miss Andress, moving heaven and earth itself, did secure a small apartment house in that same well-traveled Route de Paris, which was well enough, so far as it went, but did not go half far enough. She quickly determined that this building would serve very well as a hotel or resthouse for the casual soldiers and officers passing through the town, but that the real canteen would have to be right at the station itself.

Now the station of the Eastern Railway at Toul was amply large for the ordinary peace-time needs of the eleven thousand folk who lived in the town, but long since its modest facilities had also been swamped by the war- 
time necessities thrust upon it. It was humanly impossible to crowd another single facility within its four tight brick walls. They told her as much.

"I know that," said Miss Andress quietly. "We shall have to have a big tent set up in the station yard. I spall speak to the railway authorites about it, and gain their permission."

In vain the army officers argued with her as to the futility of such a step. They, themselves, had thought of such procedure for their own increasing activities, but had been refused a tent, very politely but very firmly. Yet those refusals were not final. There were two other factors now to be taken into consideration - one was the potency of the very phrase, Croix Rouge Américaine, with the French, and the other was the persuasive ability of a bright New York woman who, having made up her mind what it was that she wanted to get, was not going to be happy until she had gotten it.

She got the tent - the permission and all else that went with the getting it up, of course. In the spring of 1919 it still was there, although in use as a check room instead of a canteen; for the canteen service long before had outgrown even its generous facilities. It spread in various directions; into a regular hotel for enlisted men, right across the narrow street from the station; a resthouse for both officers and enlisted men back on the Route de Paris about a block distant; a huge new canteen on the station grounds, and still another on one of the long island-platforms between the tracks, so that men held in passing trains - all of which stopped at Toul for coal and water, if nothing else - and so unable to go even into the station to feel the comforting hand of the Red Cross, might be served with good things of both food and drink.

To maintain four such great institutions, even though all of them were within stone's throw of one another, was no child's play. The mere problem of providing those good things to cat and drink was of itself a really huge job. 
For by January,1919, in the sandwich room of the enlisted men's hotel across the street, 2,400 pounds of bread a day were being cut into sandwiches. These sandwiches were worthy of investigation. They were really worth-while the Red Cross kind. I have sampled them myself - all the way from Havre to Coblenz and south as far as Bordeaux, and so truthfully can call them remarkable. For fancy, if you can, corned beef - the miserable and despised "corn willie" of the doughboy - being so camouflaged with pickles and onions and eggs as to make many and many a traveling hungry soldier for the nonce quite unaware that he was munching upon a foodstuff of unbridled army ridicule. And ham, with mustard, and more of the palatable camouflage. Oh, boy, could you beat it? And, oh, boy, did you ever eat better doughnuts - outside of mother's, of course - than those of the Red Cross, and the Salvation Army, too, gave you?

In the big kitchen of the American Red Cross canteen hotel at Toul they cooked three thousand of these last each twenty-four hours, which would have been a sizable contract for one of those white-fronted chains of dairy restaurants whose habitat is New York and the other big cities of the United States, while four thousand cups of coffee and chocolate went daily to wash down these doughnuts and the sandwiches.

Figures are not always impressive. In this one instance, however, I think that they are particularly so. Is it not impressive to know that in a single day of September, 1918, when the tide of war had turned and the oncoming hosts of Yanks were turning the flanks of the boche farther and farther back, ground once lost never to be regained in the eight hours of that day, from five o'clock in the morning until one o'clock in the afternoon, just 2,045 men were served by the American Red Cross there at the Toul station, while in the month of January, 1919, just 128,637 hungry soldiers were fed and refreshed there?

Figures do not, of course, tell the story of the resthouse 
- that apartment home first secured by Miss Andress but the expressions of gratefulness that come from the fortunate folk who have been sheltered beneath its hospitable roof are more than ordinarily eloquent. It is not a large building; a structure rather ugly than otherwise. But it has spelled in every true sense of the word: "Rest." Yet to my mind its really unique distinction lies in another channel; it is the only army facility that I chanced to see in all France which extended its hospitality under a single roof to both officer and enlisted man, and so bespoke a democracy which, much vaunted at times, does not always exist within the ranks of the United States Army. For so far as I could discover, there was not the slightest particle of difference in the cleanliness and comfort between the beds assigned to the enlisted men in the upper floor of the house and those given to the officers in its two lower floors. When they passed its threshold the fine distinction of rank ceased. The Red Cross in its very best phases does not recognize the so-called distinction of rank.

Its hospitality at Toul did not cease when it had offered food and drink and lodging to the man in khaki who came to its doors. A very humble yet greatly appreciated comfort to a man coming off a hot, overcrowded, and very dirty troop train was nothing more nor less than a good bath. The bathhouse was a hurried but well-adapted one in the basement of the enlisted men's hotel. Two Russian refugees ran the plant and did well at it for Russian refugees. A system was adopted, despite Slavic traditions, by which at a single time sixteen men might be undressing, sixteen taking a quarter-hour bath, and a third sixteen dressing again - all at the same time. In this way 250 men could bathe in a single hour, while the daily average of the institution during the busy months of the war ordinarily ran from eight hundred to nine hundred. It has handled 1,200 in a 
single working day, giving the men not only a bath, hot or cold, as might be desired, but a complete change of clean underclothing - all with the compliments of the Red Cross. The discarded garments were gathered in huge sacks, some twenty-five of these being forwarded daily to the army laundries in the neighborhood.

"The Red Cross in Toul?" said a young lieutenant of engineers one day to Miss Gladys Harrison, who was working there for the American Ried Cross. "It saved my life one forlorn night. Every hotel in town was full to the doors, it was raining bullets outside and no place to sleep but the banks of the canal, if - if the Red Cross hadn't taken me in."

Let Miss Harrison continue the story; she was extremely conversant with the entire situation in Toul, and so most capable to speak of it.

"It was the hour of tea when the young man came in. In fresh white coif and apron of blue, a Red Cross girl presided behind the altar of the sacred institution, where the pot simmered and lemon and sugar graced the brew. In a charmed circle around the attractively furnished room which, among its other attractions, boasted a piano, a pretty reading lamp, and a writing desk, sat some fifteen other officers - most of them dusty and tired from long traveling, some shy, some talkative, two gray-bearded, most of them mere boys, all warming themselves in the civilizing atmosphere of the subtle ceremony. On the table piled on a generous dinner plate was the marvel on which the young lieutenant's eyes rested - doughnuts.

"Forty-eight thousand, nine hundred and ninety-five doughnuts. Not to be sure, all on that dinner plate the great number is that of the doughnuts officially stirred up, dropped in deep fat, and distributed from the Red Cross houses and station canteens during the month of July, 1918. Other good things were served in a similar abundance that same month; 19,760 hot and cold drinks, 
13,546 sandwiches, and 19,574 tartines, not to mention 2,460 salads and 4,160 dishes of ice cream - these last, of course, special hot-weather foods. But the doughnuts were the pride and glory of the Toul establishment - the masterpiece by which its praises were known and sung in the long trenches that scarred the fair Lorraine hills. They were the real American article - except also for the traditional rolling in the sugar barrel, now vanished like the dodo - soft and golden and winningly round. They were made by a Frenchwoman, but her instructor was a genuine Yankee soldier cook, who learned the art from his mother in the Connecticut Valley, where they cherish the secret of why the doughnut has a hole. He was particularly detailed to initiate the Frenchwoman into the mysteries of the art by an army colonel who understood doughnuts and men and who sat at tea with the directress one day when the Red Cross outpost at Toul still was young."

The directress was, of course, Miss Andress, and it was in those early days she still was the staff and the staff was the directress; and never dreaming of the summer nights when her commodious resthouse in the Route de Paris, with its accommodations for eight men and twentyfive officers, would be called upon in a single short month to take care of 560 officers and 2,124 enlisted men - and would take care of every blessed one of them to the fullest extent.

Enough again of figures. At the best they tell only part of the story. The boys who enjoyed the multifold hospitalities of the Red Cross in Toul - that quaint, walled, and moated fortress town of old France, with its churches and its exquistite cathedral rising above its low roofs could tell the rest of it; and gladly did when the opportunity was given them. For instance here is a human document which came into my hands one day when I was at the Toul canteen: 


\section{"Dear Red Cross Girls at the Canteen:}

"I always wanted to tell you how I appreciated all the nice things you have done for us since $I$ have been over here and would have, but perhaps you'd think I was making love to you for I felt I wanted to get you in a great big bunch and give you a great big hug. No, I wouldn't need any moonlight and shivery music, for it isn't that kind of a hug - the kind of hug I wanted to give is the kind a brother gives his sister; or a boy gives his mother when he wants her to know that he loves her and appreciates her. . . . You girls are for the boys of the fighting power and you don't ask any questions and you don't bestow any special favors and so we all love you.

"(A soldier) Mr. Buck Private."

Sometimes actions speak louder than words. There came a time - in September, 1918 - when the troops were moving pretty steadily through Toul and up toward the Argonne. The Red Cross girls were hard put to it to see that all the boys had all the food and drink and lodgings and baths that they wanted; but they saw that these were given and in generous measure, even though it meant ten and twelve and fourteen and even sixteen hours of work at a stretch. They had their full reward for their strenuous endeavors, not always in letters, or even in words. Sometimes the language of expression of the human face is the most convincing thing in all the world.

It was a boy from Grand Island, Nebraska, who slouched into the Toul canteen in the station yard on one of the hottest of those September nights. He was tired and dirty, and his seventy-five pounds of equipment upon his back must almost have been more than mortal might bear. But he did not complain - it was not the way of the doughboy. He merely shoved his pack off upon the floor and inquired in a quiet, tired voice:

"Anything that you can spare me, missy?"

He got it. Sandwiches, coffee, the promise of a bath; finally the bath itself. ... When the boy - he was indeed hardly more than a boy despite his six feet of stature - left the Red Cross colony he had been fairly 
transformed. He was cleaner, cooler, almost younger, and seeping over with appreciation.

"It was wonderful," he blurted out. "I'd like to thank you - in a practical way, sort of. Let me send you something down from the front - a souvenir like."

The Red Cross girl who had first taken him in tow and to whom he was now talking did not fully comprehend his remark. Another boy from another Grand Island already was engrossing her attention. But the word "souvenir" registered ever and ever so slightly.

"Get me a German," she said laughingly and lightly as she gave him her name, and turned to the boy from the other Grand Island.

In a few days it came; a sizable pastboard box by Uncle Sam's own army parcel post over there in France.

The girl opened it quickly. There it all was - the revolver, the helmet, the wallet, with all the German small change, the cigarette case, all the small accouterments of a private in an infantry regiment, even down to the buttons. In the package was a roughly written little note.

"I was a-going to send you his ears, too," it read, " only our top sergeant didn't seem to think that ears was a nice thing to send a lady."

A chapter of this book could easily be confined to the episodes - sometimes discouraging and at other times highly amusing - in the personal histories of the canteen workers, both men and women. There were many times when girls rode eight miles in camions to their work, and many of these girls who were well used to limousines and who knew naught of trucks until they came to France. Often those were the lucky times. For there were the other ones, too, when there was a shortage of camions and a woman must pull on her rubbers and be prepared to walk eight or ten miles with a smile on her face, and after that was done to be on her feet for eight long hours of service. It was a hard test, but the American girls stood it. 
There were the women in the little out-of-the-way canteens who struggled with coal which " acted like coagulated granite," to quote the words of one of them, and refused to ignite, save by patience and real toil. There were long hours on station platforms feeding men by passing food through car windows because there was not even time for the men to alight and enter the canteens. Moreover, the soldiers had a habit at times of leaving their savings for a canteen girl to send to the folks at home, and although this was not a recognized official part of their jobs, and, in fact, involved a tremendous amount of work, the trust was not refused. The women workers fussed with these and many other errands while the coffee brewed and the chocolate boiled.

In such canteens as those which at first catered to all of the Allies, the menus were arranged in favor of the heaviest patronage. For the visiting poilus there was specialization in French dishes. When the Italians were expected, macaroni was quite sure to become the pièce de résistance. But for the Yankee boy there has apparently never been anything to excel or even to equal good white bread, good ham, and good coffee. French coffee may be good for the French - far be it from me to decide upon its merits - but to the American doughboy give a cup of Yankee coffee, cooked, if you please, in Yankee style. On such a beverage he can live and work and fight. And perhaps some of the marvelous quality of our American fighting has been due in no small measure to the good quality of our American coffee.

Birds will sometimes revisit a country torn and swept bare by war - even as Picardy and Flanders have been torn - and so do the flowers creep back gently to cling to the earth's torn wounds - the shell holes, the trenches, the gaping walls, seeking to cover the hurts with their soft camouflage of green and glowing color. The tenderest sight I saw in bruised Péronne - Péronne which seemed 
so terribly hurt, even when one came to compare it with Cambrai, or St. Quentin, or Noyon - was a little new vine climbing up over the ruins of the parish church; and I thought of the centuries that the vines had geen growing over the gothic traceries of Melrose Abbey. Flowers gathered by the American Army served to decorate the waysides of France. The folk of that land have no monopoly of sentiment. Indeed I have often wondered if ours might not also have been called the sentimental army as well as the amazing army.

"I know why I am here," said a doughboy who was passing through Paris on his way toward leave in the south of France, and when some one asked him the reason, he replied:

"Because I am fighting for an idea. Our President says so."

I have disgressed - purposely. We were speaking of the flowers of France, which grow in such abundance in her moist and gentle climate. The very flowers that the boys of the A. E. F. picked when their trains were halted at the stations - or sometimes between them - were ofttimes given out by the Red Cross canteeners to other A. E. F. boys in far greater need of them. For these were the little costless, priceless tributes which were handed to the wounded men in the hospital trains that came rolling softly by the junction stations of the United States Military Railroad. And great, hulking men, who perhaps had given little thought at other times to the flowers underfoot, then tucked them in their shirts. Men blinded by gas held them to their faces.

\section{"Wayside!"}

The very word holds within its seven letters the suggestion of great and little adventures. It really is the traveler's own word. Is it not, after all, the special property of the wanderer, who reckons the beauty of the world not by beaten paths alone but by nooks and bypaths? 
To the vocabularies of stay-at-homes or such routine folk as commuters, for instance, it must remain unknown in its real significance. The troops which journeyed across France from the ports where our gray ships put them down - the laborers, the poets, the farmers, the business men who found themselves welded into a great undertaking and a supreme cause - will never forget the waysides of France. I mean the waysides that bore over their hospitable doors the emblem of the Red Cross and the emblem of the Stars and Stripes side by side. Sheltered in the hustle and bustle of railroad stations, in the quiet of château gardens beneath century-old trees and within Roman walls, they offered rare adventures in friendliness, in tenderness, in Americanism. 


\section{CHAPTER VII}

\section{THE RED CROSS ON THE FIELD OF HONOR}

THE triage had been set up just outside of a small 1 church which placed its buttressed side alongside the market place of the village. It was a busy place. And just because you may not know what triage really is any better than I did when I first heard the term, let me hasten to explain that it is an emergency station set up by the Army Medical Corps just back of the actual firing line - that and something more; for the triage generally means a great center of Red Cross activities as well. And this particulàr one, in the little village of Noviant, close behind the salient of Saint Mihiel - to which reference was made in the preceding chapter - was the initiation point of a Red Cross captain ; his name is John A. Kimball and he comes from Boston.

Captain Kimball told it to me one day in Paris, and I shall try to give much of it to you in his own words. He was just a plain, regular business fellow who, well outside of the immediate possibilities of army service, had closed his desk in Boston and had offered himself to the Red Cross. And to work for the Red Cross at the front was to face death as an actuality.

"The wounded already were coming in, in good numbers, on that unforgetable morning of the twelfth of September, when they brought him in - the first dead man that I had faced in the war," said he. "We had had our experiences with handling iodine and antitoxin and dressings, but this artillery captain was in need of none of these. ... His feet stuck out underneath the blanket that was thrown over the stretcher and hid his body, his head, his 
arms, and his hands. I saw that his boots were new and that they had been recently polished, too. Of course they were muddy, but I remember beneath the caking of the clay that they were of new leather. One does remember details at such a time.

"I buried him. It was a new experience, and not a pleasant one. But war is no holiday; it is not filled with pleasant experiences. And sooner or later it brings to a man a test, which, if disagreeable, is all but supreme. This was my test. I rose to it. I had to. I buried the man, ran hastily through his papers first and then sealed them into a packet to send to those who held him dearer than life itself."

Because the Boston captain's experience was so typical of so many other Red Cross men who risked their all in the service at the front lines of battle, let us take time to consider it a little in detail. He came to France at the end of June, 1918. He stayed in Paris and chafed at the delay in being held back from the fighting front. In four weeks he received his reward. Having asked to be made a searcher among killed, wounded, and missing men, he was assigned to the Second Division at Nancy, which had just come out of the hard fighting at Soissons and was resting for a brief week before going into action again.

The Second Division is one of the notable Divisions of our fighting forces that entered France. Because one wishes to avoid invidious comparisons and because, after all, it is so really hard to decide whether this Division, this regiment, or that is entitled to go down into history ahead of its fellows, I should very much hesitate to say that the Second or the First or the Third or the Twentysixth or the Seventy-seventh or any other one Division was the ranking Division of our Regular Army. But I shall not hesitate to write that the Second stood in the front rank. Out of some 2,800 Distinguished Service medals that had been awarded in France up to the first of March, 1919, 
some 800 had gone to this Division. And yet it was but one of eighty Divisions involved in the conflict over there.

In the Second Division were comprised two of the most historic Regular Army regiments of other days - the Ninth and the Twenty-third. The records of each of these commands in Cuba and in the Philippines are among the most enthralling of any in our military history. And the Ninth was the regiment chosen to enter Peking at the close of the Japanese-Chinese War and there to represent the United States Government. These regiments before being sent to the Great War in Europe were recruited up to the new fighting strength - very largely of boys from the central and western portions of New York State. In addition to these two regiments of the former Regular Army, the Second Division held several of marines, which leaves neither room nor excuse for comment. The marines too long ago made their fighting reputation to need any more whatsoever added by this book.

The Second Division in the earlier days of the fighting of the American Army as a unit had already made a distinguished reputation at both Château-Thierry and at Soissons. It was at the first point that Major General Bundy, who then commanded it, was reputed to have replied to a suggestion from a French commanding officer that he had better retire his men from an exceptionally heavy boche fire that they were then facing, that he knew no way of making his men turn back; literally they did not know the command to retreat. Our amazing army was a machine of many speeds forward, but apparently quite without a reverse gear.

When Kimball of Boston joined the Second as a Red Cross worker, General Bundy was just retiring from its command, and was being succeeded by Brigadier General John A. LeJeune, who took charge on the second of August, at Nancy; for the Division was spending a whole week catching its breath before plunging into active fighting 
once again. On the ninth its opportunity began to show itself. It moved to the Toul front in the vicinity of the Moselle River, and was put into a position just behind the Saint Mihiel sector - that funny little kink on the battle front that the Germans had so long succeeded in keeping a kink.

For a long time - in exact figures just a month, which to restless fighting men is a near eternity - the sector was quiet. There were practically no casualties; and this of itself was almost a record for the Second, which in four months of real fighting replaced itself with new men to a number exceeding its original strength. In that month the Division prepared itself for the strenuous service on the fighting front. It went into camp for eleven days at Colombes-la-Belles, within hiking distance of the actual front, and there practiced hand-grenade work while it made its final replacements. The work just ahead of it would require full strength and full skill.

On the twenty-seventh of August it began slowly moving into the front firing line. From the first day of September until the eighth it worked its way through the great Bois de Sebastopol (Sebastopol Forest), marching by night all the while, and covering from eight to nine miles a night. And upon the night of the eleventh - the eve of one of the most brilliant battles in American history - took over a section of the trenches north of the little town of Limey.

"Your objective is Triacourt," the officers told the men that evening as they were preparing for going over the top at dawn, "and the Second is given two days in which to take it."

Triacourt fell in six hours.

Count that, if you will, for an American fighting Division.

The headquarters of the Second were at Mananville to the south of the fighting lines. And halfway between Limey of the trenches (they ran right through the streets 
of the little town) and Mananville was Noviant where, as you already know, the triage was established beside the walls of the church and the Red Cross functioned at the front. Remember that the triage was nothing more nor less than a sorting station, where wounded men, being sent back in a steady stream from the front - three to six miles distant - were divided between four field hospitals of the Regular Army service; one handling gassed cases, another badly wounded, and the other two the strictly surgical cases. Each of these divisions consisted roughly of from ten to fifteen doctors and about one hundred enlisted men - no women workers were ever permitted so near the front - and was equipped with from five to eight army trucks of the largest size.

There has been sometimes an erroneous impression that the Red Cross was prepared to assume the entire hospital functions of the United States Army; I have even heard it stated by apparently well-informed persons that such a thing was fact. It is fact, however, that if the enormous task had been thrust upon the shoulders of our Red Cross it would have accepted it. It has never yet refused a work from the government - no matter how onerous or how disagreeable. As a matter of fact, the army, for many very good and very sufficient reasons of its own, preferred to retain direct charge of its own hospitals, both in the field and back of the lines, and even took over the hospitals which the Red Cross first established in France before the final policy of the Surgeon General's office was definitely settled, which hardly meant a lifting of responsibility from the shoulders of the American Red Cross. Its task, as we shall see in the chapters which immediately follow this, was almost a superhuman one. It needed all its energies and its great resources to follow the direct line of its traditional activity - the furnishing of comfort to the sick, the wounded, and the oppressed.

A wise man, one with canny understanding, if you will, who found himself at the Saint Mihiel sector would have 
understood that a battle was brewing. There was a terrific traffic on each of the roads leading up toward the trenches from the railhead and supply depot at the rear big camions and little camionettes, two-man whippet tanks, French seventy-fives (as what is apparently the best field cannon yet devised will be known for a long time into the future), motor cars with important-looking officers, ambulances, more big camions, more little camionettes - all a seemingly unending procession. Fifth Avenue, New York, or Michigan Avenue, Chicago, on a busy Saturday afternoon could not have been more crowded, or the traffic handled in a more orderly fashion.

The barrage which immediately preceded the actual battle began at one o'clock on the morning of the twelfth. It lasted for nearly four hours and not only was noisily incessant but so terrific and so brilliant that one could actually have read a newspaper from its continuous flashes if that had been an hour for newspaper reading.

"It was like boiling water," says Kimball, "with each bubble a death-dealing explosion."

At five o'clock in the morning the men went over the top, and our Red Cross man shook himself out of a short, hard sleep of three hours in a damp shed near the triage beside the church at Noviant, for it had been raining steadily throughout the entire night, and went across to that roughly improvised dressing station. His big day's work was beginning. By six it was already in full swing. The first wounded men were coming back from the fighting lines up at Limey and were being sorted into the ambulances before they were started for the three big evacuation hospitals in the rear - each of them containing from three hundred to five hundred beds. The Boston man saw each wounded soldier as he was placed in the ambulance. Into the hands of those men who asked for them or who were able to smoke he gave cigarettes. And to those who were far too weak for the exercise or strain that smoking brought, gave a word of encouragement or perhaps a shake 
of the hand. And all in the name of the Red Cross.

He could have put in a busy day doing nothing else whatsoever; but felt that there were other sections of the battle front that needed the immediate presence of the American Red Cross. So at about half after seven he climbed in beside the driver of a khaki-colored army camionette and headed straight for Limey, and the heart of the trouble. There was another old and badly battered church in the town square there, and there a new triage already was being established; for the Yanks were driving forward - with fearful impetus and at a terrific rate. So the hospital went on, the sorting stages, with their indescribable scenes of human suffering - more stretchers and still more in the hands of boche prisoners coming in with their ghastly freight. Captain Kimball again passed out his cigarettes and started forward. Now he was on the scene of actual warfare. Dawn had broken. It had ceased to rain and the sky was bright and blue with white, fluffy, sun-touched clouds drifting lazily across it - just as the Boston boy had seen them drift across the sky in peaceful days on Cape Cod when he had had nothing to do but lie on his back and gaze serenely up at them.

"I plunged forward over the broken field," he told me, "and there I came across my artillery captain. I called an aid and we took him back - he of the bright new boots that had so recently been polished. . . . I got back into the game. All the time our boys shot ahead and the racket was incessant. Once, when I bumped my way across the German trenches, I paused long enough to stick my nose down into one of their dugouts. It was easy to see that the enemy had not anticipated the attack. For in that dugout - it was wonderfully neat and nice, with its concrete walls and floors and ceiling and its electric lights - was the breakfast still upon the table; the bread, the sausages, and the beer. I could have stayed there an hour and enjoyed it pretty well myself. But there were other things to be done. I got out into the shell-plowed 
fields once again. Across that rough sea of mud an engineer regiment was already building a road, which meant that we could get a Red Cross ambulance right to the very front. I walked back to Limey - or rather I stumbled over the rough fields - and there found one which had come through from Toul that morning, loaded to its very roof with bandages and chocolates and cigarettes. And I found that Triacourt had fallen. It still lacked some minutes of noon. The job for which our Division had been given two days had been accomplished in six hours but such hours.

"We drove without delay into Triacourt - a fearfully slow business every foot of it, with every inch of the hastily constructed road crowded with traffic. But we got through and in the early afternoon were in the main street of the little town which the French had watched hungrily for four years and seemingly had been unable to capture. The women and children of the place came out into the sun-lighted street and rubbed their eyes. Was it all a dream; these men in tin helmets and uniforms of khaki and of olive drab? No, it could not be a dream. These were real men, fighting men. These were the Americans, the Americans of whom rumors had even run back of the enemy lines. They found their voices, these women, for the Germans had taken the men of Triacourt as prisoners. "Bons Américains!" they shrieked, almost in a single cry. And we saluted gravely."

Over the heads of the two Red Cross men - the captain and the driver of the little camionette - an aftermath of the battle in the form of an air fight between boche planes and American was in progress; young Dave Putnam, one of the most brilliant of our aces, was making the supreme sacrifice for his country. To the north the Germans were dragging up a battery and preparing to shell the little town that they had just lost; but not for long. Batteries of American .155's were appearing from the other direction and were working effectively. And at dusk a report came 
into Division Headquarters that a company of one of the old Regular Army regiments had captured an entire German hospital - patients, nurses, doctors, and even two German Red Cross ambulances; while the tingling radio and the omnipresent telephone began to bring into Division Headquarters the story of one of the most remarkable American victories of the entire war. And our Red Cross began the first of a four days' stay in a damp dugout in the lee of a badly smashed barn.

Kimball's story is quite typical of many others. But before I begin upon them - what the motion-picture director would call the "close-ups" of what is perhaps the most picturesque form of all the many, many picturesque features of our Red Cross in action, consider for a moment how it first got into action upon the field of battle. I have referred several times already to the excessive strain which the great German offensives which began in March, 1918, placed upon its facilities, while they still were in a stage of development. When we read of the work of the Transportation Department and of the Bureau of Supplies, we saw how both of these great functions had suddenly been confronted with a task that demanded the brains and brawn of supermen and how gloriously and brave-heartedly they had arisen to the task. The field service of our Red Cross - its first contact with the men of our army in actual conflict - was second to neither of these.

Remember, if you will, that it was but a mere nine months after the American Red Cross Commission to Europe landed in France that its organization was put to its greatest test. The news of the long-expected and welladvertised German offensive reached Paris on the very evening of the day on which it started, March 21, 1918. Paris caught the news with a choking heart. The coup, which even her own military experts had frankly predicted as the turning point of the entire war, actually had come 
to pass. No wonder that the once gay capital of the French fairly held its breath in that unforgetable hour that every other community of France, big or little, did the same - and fairly fought for news of the day's operations. Yet news gave little comfort. It was bad news, all of it; fearfully and unmistakably bad. Each succeeding courier seemed to bring enlarged statements of the enemy's immensity and seemingly irresistible force. It was indeed a real crisis.

In that hour of alarm and even of some real panic, our American Red Cross showed neither. It kept its cool and thinking head. Major James H. Perkins, then ranking as Red Cross Commissioner to Europe and a man whom you have met in earlier pages of this book, called a conference of his department heads on that very evening of the twenty-first of March. He told them quietly that they were to make known every resource at their command and to have each and every one of their workers - men or women - ready for call to any kind of service, night or day.

"Let every worker feel that on him or her individually may rest the fate of the allied cause," was the keynote of the simple orders that issued from this conference.

It was in the days that immediately followed that the flexibility and the emergency values of the American Red Cross organization - qualities that it had diligently set forth to attain within itself - came to their fullest test. The discipline and willingness of practically every worker was also under test, while for the very first time in all its history overseas it was given large opportunity to carry to the men of the allied lines a great material message.

How well was that material message carried?

Before I answer that point-blank question, let me carry you back a little time before that night of the spring equinox. Let me ask you to remember, if you will, that the super-structure of Red Cross effort in that critical 
hour had been laid many weeks before; in fact very soon after its original unit of eighteen men under command of Major Murphy had first arrived in France. It had experimented with the French, in definite and successful efforts to relieve the hard-pressed civilian population of that distressed country. It had worked, and worked hard, in the broad valleys of the Somme and the Oise, which had been devastated by the boche when he made his famous "strategic" retreat to the Hindenburg Line in March, 1917 just one year before.

The Germans had left behind them an especial misery in the form of a vast region of burned and blown-up homes, broken vehicles and farm machinery, defiled wells, hacked and broken orchards, and ruined soil. I have stood in both of these valleys myself after German retreats and so can bespeak as personal evidence the desolation which they left behind. I, myself, have seen whole orchards of young fruit trees wantonly ruined by cutting their trunks a foot or more above the level of the ground. And this was but a single form of their devilment.

Yet as the Germans retreated "strategically" there in the spring weeks of 1917 , there followed on their very heels the heavy-hearted but indomitable refugees who in yesteryear had known these hectares as their very own. Returning, they found but little by which they might recognize their former habitats. Devastation ruled, life was practically extinct. The farm animals, even the barnyard fowls and the tiny rabbits - the joy of a French peasant's heart - had been killed or carried away. Not even the bobbins of the cast-out sewing machines or the cart wheels were left behind by an enemy who prided himself on his efficiency, but who had few other virtues for any decent pride.

Seemingly stouter-hearted folk than the French might have quailed at such wholesale destruction; but the refugees did not complain. Instead, they set patiently to work many of them still within the range of the enemy's 
guns - to rehabilitate themselves. Their burdens and their problems were staggeringly great; their resources pitifully small. Thus our Red Cross found them, and to give them effective aid - not only in the valleys of the Somme and the Oise, but in the other devastated areas of France - formed the Bureau of Reconstruction and Relief under Edward Eyre Hunt. Of Mr. Hunt's work, the record will be made at another time. In order, however, that you may gain the proper perspective on the beginnings of the field service of our Red Cross with our army in action, permit me to call attention in a few brief sentences to some salient features of the Bureau of Reconstruction and Relief.

It located warehouses at convenient places-Ham, Noyon, Arras, and Soissons - all of them within gunshot of the Hindenburg Line. These were stocked with food, clothing, furniture, kitchen utensils, building materials, seed, farm implements, even with rabbits, chickens, goats, and other domesticated animals. A personnel of several field workers was sent into the district to supervise the distribution of these commodities, which was done partly through authorized French committees and municipal officers in the devastated towns. These coöperated with devoted groups of British, French and American workers, who established themselves in small groups and who worked to inspire the liberated areas with faith and courage and hope. Looming large among all these coordinated agencies were the Smith College Unit - composed of graduates of the Northampton institution and the group of workers from the Society of Friends both of whom, in the fall of 1917, became integral parts of the Red Cross.

These two coördinated agencies, together with the Secours d'Urgence, the Village Reconstitue, the Civil Section of the American Fund for the French Wounded, the Philadelphia Unit, and the Comité Américaine pour les Régiones Dévastees, had their various operations well 
under way by the early summer of 1917 . When it entered the field, our American Red Cross offered assistance in every way to these organizations, thereby giving a new impetus to their work. Agricultural societies were organized for the common rehabilitation of the areas, American tractors and plows were furnished by the French Government, while the Red Cross workers helped with and encouraged the planting, furnishing large quantities of seeds as they did so, while small herds of live stock, also given by the Red Cross, appeared here and there upon the French landscape.

The workers did even more. They turned to and helped patch up buildings that, with a minimum amount of labor, could again be made habitable, erected small barracks in some places, and assisted generally in renewing life and the first bare evidences of civilization in the towns of the desolated sections.

In March, 1918, these desecrated lands were just springing to life once again. God's sun was breaking through the clouds of winter and gently coaxing the wheat up out of the rough, brown lands, gardens again dotted the landscape - the Smith College Unit itself had supervised and with its own hands helped in the planting of more than four hundred and fifty of these - the little villages and the bigger towns were showing increasing signs of life and activity; then came the blow. The clouds gathered together once again. And in the misty morning of the twenty-first of March began a week of horror and devastation - a single seven days in which all the patient, loving labor of nearly a twelvemonth past was erased completely. The Germans swept across the plains of Picardy once again - the French and British armies and the terror-stricken civilians along with the American war workers were swept before them as flotsam and jetsam, all in a mad onrush. Yet all was not lost. One field worker, a stout-hearted little woman in uniform, sat in the 


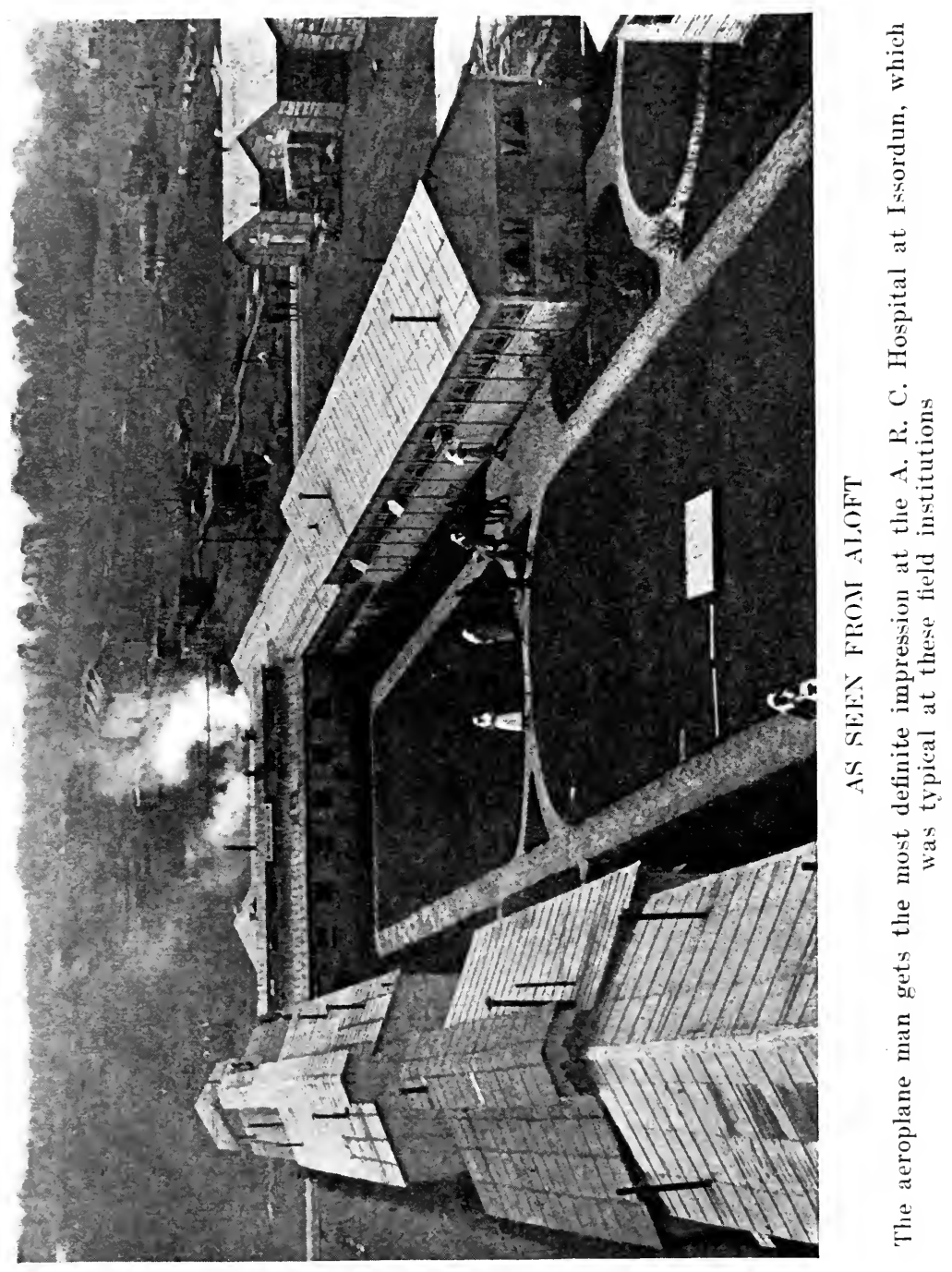



seat of a swaying motor truck and as the thing rolled and tossed over a road of unspeakable roughness wrote in her red-bound diary, this:

"The best of all remains - the influence of neighborliness, friendship, kindness, and sympathy - these are made of the stuff which no chemistry of war can crush. We face more than half a year's work torn to pieces. But I do believe that the fact of this sacrifice will deepen its effect."

Such was the spirit of our Red Cross workers overseas.

They now had full need for such spirit. The monotony of working from daylight to dusk in lonely farms and villages, where patience was the virtue uppermost, was now to be replaced by a whirl of events which succeeded one another with kaleidoscopic rapidity, demanding service both night and day of a character as varied as the past had been colorless.

The headquarters of the American Red Cross for the Somme district on the morning of the twenty-first of March, 1918, were at Ham - the little village once made famous by the imprisonment and escape of Louis Philippe. They were in charge of Captain William B. Jackson, who afterwards became major in entire charge of the Army and Navy Field Service. Here at Ham was also the largest Red Cross warehouse in the entire district. Another warehouse stood at Nelse, a few miles distant, to the rear. To the north was Arras, with still another American Red Cross storehouse, while to the south was the Soissons warehouse.

On that same morning - one cannot easily efface it from any picture of any continued activity of the Great War - the Smith College Unit workers had gone from their headquarters at Grecourt, both on foot and in their four Ford cars, to their various tasks in the seventeen small villages in the immediate vicinity. Two or three of these young women journeyed to Pommiers, a little town in 
the area, whose school had been reopened by them, and which also served the children of several surrounding villages. And because so many of the children had to walk so far to their lessons the Red Cross served them each day with a substantial school lunch - of vermicelli, chocolate, and milk. A few others of the college graduates went a little farther afield - to supervise planting operations in near by towns - yet not one of these girls was one whit above turning to and working on the task with her own hands, while some helped the Red Cross workmen's gangs roofing houses and stables, repairing shops and fitting outbuildings, in some crude form, for human habitation.

Into the very heart of those varied activities that March morning marched the red-faced British Town Major of Ham with the blunt and crisp announcement to the Red Cross man that the town must be evacuated without delay; the retreat already was well under way, the vast hegira fairly begun. ... The Red Cross force there at Ham did not hesitate. It first sent word to all the workers in the villages roundabout; then, having quickly mobilized in the town square its entire transportation outfit - three trucks, a camionette, and a small battered touring cargave quiet, prompt attention to its own immediate problem of evacuation work.

It functioned fast and it functioned extremely well. Back and forth across the River Somme - over the rough bridges hurriedly builded by Americans for the British Army - it transported hundreds and hundreds of children and infirm refugees. All that day, all that night, and well into the next morning it worked, driving again and again into the bombarded towns in the region to bring out the last remaining families. The Germans were already on the edge of the town when one Red Cross driver made his last trip into Ham - on three flat tires and a broken spring! Yet despite these physical disabilities succeeded in carrying six wounded British soldiers out to safety.

To our Red Cross the Smith College girls reported, with 
great promptitude. And throughout the entire succeeding week - a deadly and fearfully depressing seven days of continued retirement before the advancing Germans showed admirable courage and initiative; the sort of thing that the military expert of to-day classes as morale of the highest sort. These women worked night and day setting up, whenever the retreat halted even for a few hours, temporary canteens and dispensaries and evacuating civilians and carrying wounded soldiers through to safe points behind the lines. And because many of these last were American soldiers they formed the first point of field contact between our Red Cross and our army and so are fairly entitled to a post of high honor in the pages of this book.

"Send me another sixty of those Smith College girls," shouted an American brigadier general from his field headquarters in the fight at Château-Thierry. "This forty isn't half enough. I want a hundred."

The college graduate in charge of the temporary canteen there who received this request laughed.

"Tell him," she said, "that there have been no more than sixteen at any one time."

But sixteen human units of individual efficiency can move mountains.

Take the Smith girl who drove a Red Cross car through the tangle of war traffic at a crossroads near Roye, while the fighting waged thick around about that little town. She found her Fordette stalled and tangled in several different lines of communication; between ammunition trucks, supply camions, loads of soldiers, batteries all, like herself, stopped and standing idle and impotent.

The girl sensed the situation in an instant. She must have been a New Yorker and have remembered the jams of traffic that she had seen on Forty-second Street; at Broadway and again at Fifth Avenue. At any rate she acted upon the instant. She descended from the seat of her little car, and, standing there at the crossing of the 
roads with an American flag in her fingers, directed traffic with the precision and good sense of the skilled city traffic cop. She held up staff cars, directed whole regiments of artillery, shouted orders to convoys, and for several hours kept the important corner from becoming another hopeless tangle of traffic. Her orders were not disputed, either by private or general. All ranks smiled at her, but all ranks saluted and obeyed her orders.

It was in situations such as this that the rare combination of military discipline, the flexibility to permit of human initiative that the Red Cross sought to attain in its inner self, showed itself. The plan of withdrawal which had been carefully mapped out at headquarters was implicitly followed - almost to its last details. Yet the personnel of the organization was both permitted and encouraged to work at its highest efficiency both in evacuating human beings and salvaging the precious supplies. For instance, after that first day of the great retreat, when all the Red Cross workers in the area had reported to their chiefs at Nelse and at Roye - both well to the rear of Ham - they were dispatched to work up and down the entire constantly changing front. Geographically, Soissons was the hub of the wheel on which these emergency Red Cross activities turned so rapidly. They all swung back in good order, each unit, by motor-courier service, keeping in communication with its fellows. Roye was the center of the secondary line of the Red Cross front which for the moment stretched from Amiens in the northwest to Soissons in the southeast. When it was driven from this line the entire Red Cross force in the vicinity retired, still in good order, to a brand-new one, stretching across Amiens, Montdidier, and Noyon. From the small American Red Cross warehouse at this last town, a stock of valuable supplies was quickly evacuated to Lassigny, a short distance still farther to the rear. Noyon quickly became a center of feverish activity and the focus of Red Cross efforts on the third day of the battle. From 
it Red Cross cars worked, both day and night, evacuating men and women and goods.

The line held across Montdidier, Noyon, and even Lassigny for a bare twenty-four hours more; for on the fourth day of the retreat all three had to be abandoned, and new quarters established on a line closer to Paris than any of the others; it passed through both Beauvais and Compiègne, where emergency Red Cross headquarters were once again established; but for the last time. This line was destined to be a permanent one. The retreat was slowing down, slowly but very surely halting. And our Red Cross with our Yanks and their Allies were "digging in."

The impressions which the great German drive made upon the minds of our workers who fell back before it will remain with them as long as thought and memory cling - the vast conglomeration of men, tired, dirty, unshaven; men and animals and inanimate things, moving quickly, slowly, intermittently, moving not at all, but choking and halting all progress - with the deadly perversity of inanimate things; men not merely tired, dirty and unshaven, but sick and wounded almost unto death, moaning and sobbing under the fearful onslaughts of pain unbearable, sometimes death itself, a blessed relief, and marked by a stop by the roadside, a hurriedly dug grave, prayers, the closing earth, one other soul gone from the millions in order that hundreds of millions of other souls may live in peace and safety. Such traffic, such turmoil, such variety, such blinding, choking dust. Army supply trains, motor trucks, guns, soldiers, civilians, on foot and mounted, of vehicles of every variety conceivable and many unconceivable; motor cars upon which the genius of a Renault or a Ford had been expended; wheelbarrows, baby carriages, sledges, more motor cars, ranging in age from two weeks to fourteen years, dog carts, wagons creaking and groaning behind badly scared mules and 
worse scared negroes who wondered why they had ever left the corn brake - for this. Such traffic, such life. And then - again and again death, more graves, more prayers, more men's souls poured into the vague unknown.

And in the midst of death, life. Here in this wagon is a haggard-looking woman. The babe which she clasps to her breast is but four hours old; but the woman is a hundred - seemingly. She stretches her long, bare arms out from the flapping curtains at the rear of the Red Cross camionette. A group of poilus, in extremely dirty uniforms, catches her eyes. She shrieks to them in her native French.

"My poilus," she cries, "you shall return. God wills it. You shall return - you and my little son," and falls, sobbing incoherently, into the bottom of the bumping ambulance.

An old woman with her one precious possession saved - a bewhiskered goat - hears her, and crosses herself. A three-ton motor truck falls into a deep ditch and is abandoned, with all of its contents. This is no hour for salvage. The dust from all the traffic grows thicker and thicker. Yet it is naught with the blinding white dust which arises from this shell - which almost struck into the heart of one of the main lines of traffic. The racket is terrific; yet above it one catches the shrieking cry of the young mother in the camionette. Her reason hangs in the balance. And as the noise subsides a detachment of poilus falls out beside the roadside and begins opening more graves. The boche's aim was quite as good as he might have hoped.

In and out of these streams - this fearful turmoil of traffic, if you please, our Red Cross warped and woofed its fabric of human godlike love and sympathy. With its headquarters established with a fair degree of permanency both at Compiègne and Beauvais, it increased its attention to the soldiery. It set up a line of canteens and soup- 
kitchens along the roadside all the way from Beauvais, and these served as many as 30,000 men a day with hot drinks, cigarettes, and food of a large variety, and showed a democratic spirit of service in that they gave, without question or without hesitation, to Frenchmen, to Britons, to Italians, and to Americans alike. The men and the girls in the canteens were blind to things, but their ears were ever alert, and they heard only the voices of the tired and the distressed asking for food and drink.

At Compiègne the Red Cross took over the largest hotel, which, like the rest of the town, had been evacuated so hurriedly that parts of a well-cooked meal still remained upon the tables of the great salle-à-manger. Instantly it rubbed its magic lamp and transformed the hostelry into a giant warehouse, infirmary, and, for its own workers, a mess hall and barracks. And as the endless convoys rolled by its doors and down into the narrow, twisting, stonepaved streets of Compiègne, these workers stood at the curb opening up case ofter case of canned foodstuffs and tossed or thrust the cans into the waiting fingers of the half-starved drivers of the trucks and camions.

Individual initiative - that precious asset of every American - had its fullest opportunity those days at Compiègne. It mattered not what a man had been or what he might become; it was what he made of himself that very hour that counted. A minister who had come over from America to do chaplain service for the army bruised his poor unskilled fingers time and time again as he struggled, with the help of a clerk from the Paris offices, with the stout packing cases. Departmental and bureau lines everywhere within the Red Cross had been abolished in order to meet the supreme emergency. Rank melted quickly away before the demand for manual labor. The Red Cross showed the flexibility of its organization, and Compiègne was, in itself, a superb test.

It was down at the railroad station in that same fascinating, mediæval city of old France that a portable 
kitchen, hauled out on the great north road up from Paris, with three American business men fresh from their desks in New York, hanging perilously on to its side like volunteer fire laddies of long ago going on old "Rough and Ready" to a regular whale of a blaze, was set up on the exact spot where one Jeanne d'Arc once had been taken prisoner. Its mission of salvation was far more prosaic; yet, in its own humble way, it too functioned, and functioned extremely well. It served food and hot drinks to more than ten thousand soldiers each day.

The variety of opportunity, of service to be rendered, was hardly less than stupendous. For instance, when word came to Compiègne from Ressons that the French would finally be compelled to evacuate their hospital there and lacked the proper transportation facilities, our Red Cross stepped promptly into the breach and moved out the precious supplies. It did not ask whether or not there were American boys there in the wards of the French hospital - there probably were, the two armies being brigaded together pretty closely at that time; it sought no fine distinctions - in that time, in that emergency, the French were us, we were the French - and so sent its trucks hurrying up to Ressons, equipped with a full complement of workers. And these worked until the retreating Allies had established a third line in the rear of them and the advancing Germans were but two hours away.

All this while the transformed hotel at Compiègne remained a huge center for these multifold forms of Red Cross relief. It, too, formed a clearing house for assistance. Its ears were alert to the vast necessities of the moment. They listened for opportunities of service. There were many such. A refugee brought word that an old couple in a farmhouse full ten miles distant had no way of retreating before the onrushing Germans. Without a minute's delay a camionette was dispatched to the spot and it brought the wceping, grateful pair and most of 
their personal belongings to safety; while other cars were sent in various directions to seek out the opportunites of performing similar services. . . . As this situation eased itself, this transportation equipment was turned toward the carrying of supplies and tobacco to the weary men of isolated batteries and units along the ever changing battle front. It was an almost unceasing task, and the few short hours that the Red Cross workers forced themselves into an all-necessary sleep were all spent in the caves and abris of Compiègne; for the boche aviators had an unpleasant habit of making frequent nocturnal visits to it.

At Beauvais, simultaneous with the establishment of the headquarters at Compiègne, the American Red Cross opened both military and civilian hospitals, together with a rest station of some three hundred beds for slightly wounded soldiers and for casuals; as men detached from their units are generally known. Over a bonfire in a small hut the workers cooked food and served it hot to the soldiers and the refugees. In fact this town had been made a clearing station for these last. Each incoming train brought more and more of these pitiful folk into the town, where they were halted for a time before being sent on other trains to the districts of France quite remote from any immediate possibility of invasion. In the few hours which refugees spent in Beauvais our Red Cross made some definite provision for their comfort. It secured a huge building, obtained several tons of hay, and after establishing a rough form of bus service with its motor cars, transported them from the station to its hastily transformed barracks for a night's rest, and then, on the following morning, back to the railway station and the outgoing trains to the south and west. And with the barracks and the hay cots went blankets and food, of course. It was crude comfort; but it was infinitely better than spending the night on the stone floor of a damp and unheated railroad station. 
At Niort, where a small store of Red Cross supplies had been sent to a designated delegate, the delegate on an hour's notice fed four hundred refugees, while at Clermont the American Red Cross supplied food to a nunnery that had opened its doors to refugees. So it went. The variety of services was indeed all but infinite; while through the entire nightmare of activity, the workers were thrust upon their own initiative - that precious American birthright, - time and time again. Their only orders were short ones; they were to help any one and every one in need of assistance.

How the French viewed this aid and how they came to rely upon it, is best illustrated, perhaps, by the testimony of a hardware merchant of Soissons whose house had been shelled. Without hesitation he came direct to the Red Cross headquarters for help, saying:

"I come to you first because it has become natural for us to go to the Americans first when we are in need."

And from a refugee station near Péronne, a Red Cross worker reported:

"They are all looking to me, as a representative of the American Red Cross, to act as a proper godfather."

As the days passed, the work in this vital area was greatly expanded and increased. The refugees gradually were evacuated through to Paris and beyond, while the service in the valleys of the Somme and the Oise became more strictly military in character. It became better organized, too. But I feel that this last is not the point. We Americans are rather apt to place too great a stress upon organization. And the fact remains that the Red Cross in its first military emergency, with very little organization, indeed, attained a proficiency in service far greater than even its most optimistic adherents had ever dreamed it might attain.

I have turned the course of my book for a time away from the direct service of our Red Cross to our own army 
because I wanted you to see how and where that directservice field was founded. From that beginning, at the start of the German drive, it grew rapidly and steadily and, as I have just said, with certain very definite benefits of organization. The drive halted, became a thing of memory, was supplanted by another drive - of a different sort and in the opposite direction - a drive that did not cease and hardly halted until the eleventh day of November, 1918. That was the drive so brilliantly marked with those epoch-making tablets of the superb romance of our American adventure overseas - Château-Thierry, Veaux, Saint Mihiel, the Argonne - many other conflicts, too.

In all of these the American Red Cross played its part, and seeks no greater testimony than that so generously volunteered by the very men who received its benefits - the doughboys at the front. They know, and have not been hesitant to tell. My own sources of information are for the most part a bit official - the records made by the Red Cross workers in the field. These tell more eloquently than I can of the work that was done there and so I shall quote quite freely from them.

"My billet has stout cement walls, a mighty husky ceiling and a dirt floor," writes Lieutenant J. H. Gibson of Caldwell, Idaho, who was attached to the Thirty-third Division. "The furniture consists of my cot and sundry goods boxes, camouflaged with blankets to make seats, and I have frequent callers. Generally they are casuals men who have lost their organizations and don't know where to go or what to do. I had three of them the first day, footsore, weary, and homesick. I rustled them a place to get mess, loaded them into my car, and drove them to the nearest railroad railhead, where I found a truck belonging to their Division, stopped it, and got them aboard."

Under date of October 13, 1918, Lieutenant Gibson further wrote:

"This has been another of those days spent most in 
quarters, busy with paper work. I find a thundering lot of letter writing necessary in connection with my Red Cross duties. I am the Home Communication and Home Service Representative for the Division in addition to being division 'scrounger.' When any of the folks back home want information about their soldier boys I am supposed to furnish it and, vice versa, when any of the soldier boys have home problems I am expected to help them. While I am resting $I$ act as Division shopper, for fighting men need things just the same as ordinary mortals, and I take their orders, have the goods bought through the Red Cross in Paris, and distribute them, collecting the money. When the Division is in action I administer comfort to the wounded in addition to gathering data as to the deaths. Between times I scout roads, carry dispatches, and help the sanitary train generally. If the devil has work only for idle hands he can pass me by.

"At dressing stations we endeavor to do two things; to re-dress the wounds and to administer some nourishment. The men wounded have received first aid treatment on the field or at the battalion-aid post and they walk or are carried on litters to the dressing station. There we put them into ambulances or trucks and they go out to the evacuation hospitals. My part of the job was the nourishment end, and so I got a detail of men, improvised a fire, stole a water bucket from another Division which had more than it needed, opened up some rations, and soon was serving hot coffee, bread, and jam to the wounded, endeavoring the while to kid a grin into the face of each. The last was the easiest job for our fellows were sure gritty. I think I batted a thousand per cent on the smile end of the game." Under date of October 24, 1918:

" Back from Paris. I rolled out fairly early and got my boxes opened. The boys certainly appreciate the Red Cross shopping service and fairly swarmed in after the articles we had procured for them. There was everything imaginable in the lot - watches, boots, cigars, cigarettes, 
and candy being the prime favorites. One buddy had a mandolin and another some French grammars. I was overwhelmed and had to get an assistant detailed, for in addition to making deliveries I had to take orders. Every one wanted to order something. About sixty-five additional orders were placed to-day and I didn't even have time to open my mail."

A week later:

"I spent the day at my billet, busy with the correspondence which my position with the Red Cross necessitates and which, by the way, is a little difficult to handle in view of the fact that I am minus every convenience. Letter files, index cards, guides, and cabinets are about as scarce as hen's teeth. It is wonderful, however, just what a man can do without. A small goods box will make a very passable letter file, and a cigar box, the kind that fifty come in, can be made into a reasonably useful card-index tray. I was wise enough to bring a small typewriter from the states and it has proven absolutely indispensable. . . . The men are in rest billets and the delouser and shower baths are busy cleaning them up. The men come in squads to the building which houses the equipment, strip off their clothing which goes to the delouser, where they are dry-baked at a temperature sufficiently high to kill the nits. While this is being done they are thoroughly scrubbing themselves, and when they are through with the bath, their clothes are finished and ready to be put on. The Red Cross never did a better thing than when it furnished this equipment to my division."

Permit me to interrupt Lieutenant Gibson's narrative to explain in somewhat greater detail the operation of these Red Cross portable cleansing plants which added so greatly to the comfort of the doughboys, not only in the field, but, in many cases, in rest billets or camps far back from it. It so happened that many times the men in the front lines would go weeks and even a full month without the opportunity of a decent bath. Such is war. It is a known fact 
that the boys of the Third Division once spent a full five weeks in the trenches without even changing their clothes, after which they were sent behind to a Red Cross cleansing station and bathed and refitted with clean clothing before being sent back again - with what joy and refreshment can easily be imagined.

The type of portable shower used in many cases was generally known as the "eight-headshower" or field douche. It consisted of a simply designed water tank with fire box, in which might be burned coal or wood, a pipe line with eight sprays, and flooring under the sprays. The thing was easily adjusted. In a building with water supply it was a simple matter indeed to connect the tank with the water supply; while in the open field, where there might be neither water pressure nor water connection, the precious fluid could be poured into the tank with buckets. The apparatus was durable and reasonably "fool-proof."

During the Château-Thierry drive nine of these portable showers were set up by our Red Cross, and in one week, seven thousand men were brought back from the firing line, bathed, given clean clothes, and sent back refreshed mentally and morally as well as physioally. Sixty men an hour could easily be bathed in one of these plants, and two gallons of water were allowed to each man.

The delouser, as the army quickly came to know the sterilizing plant, almost always accompanied the portable shower upon its travels. It, too, was a simple contraption; a great cylinder, into which the dirty clothing was tightly crammed until it could hold not one ounce more, and live steam poured in, under a pressure of from sixty to one hundred and fifteen pounds to the square inch. This was sufficient to kill all the vermin; and, in some cases, the bacteria as well, although this last was not guaranteed. The delouser, with a capacity of fifty suits a day, could almost keep pace with one of the shower baths, and both could be set up or taken down in ten minutes. 
A shower bath mounted on a Ford was one of the best friends of the Eighty-first Division as it played its big part in the defeat of the Hun. It made its first appearance in September, when the Division was stationed in the Vosges, with headquarters at St. Dié. After a few hard days in the trenches the men would return to their headquarters, well to the rear of the lines, and beg for some sort of bathing facilities - and these, apparently, were not to be found.

Captain Richard A. Bullock was our Red Cross man with the Eighty-first. It bothered him that the men of his Division could not have so simple a comfort when they asked for it and needed it so much. He determined to try and solve the problem, and so found his way down to the big American Red Cross warehouse and there acquired one of the portable field equipments such as I have just described. It was a comparatively easy trick to mount the device on a Ford, after which Bullock paraded the entire outfit up and down the lines of the Eighty-first and as close to the frontline trenches as fires were ever permitted. In a mighty short time he could get the bath in order and showering merrily, and when all the men who wanted to bathe had been accommodated the contraption would move on.

For the camps where larger numbers of men must be bathed, the Red Cross, through its Mechanical Equipment Service of its Army and Navy Department, provided even larger facilities, although still of standardized size and pattern. This was known as the pavilion bath and disinfecting plant and could easily take care of 150 an hour. Where the sterilization of their clothing was not necessary this number was very greatly increased. In fact at one time a record was made in one of the large field camps of bathing $608 \mathrm{men}$ in two hours through a single one of these plants. In another, which was in operation at the Third Aviation Center, 3,626 men bathed in one week in a total of twenty-eight operating hours and some 4,200 men in the second week. It was estimated that the plants could, if 
necessary, be operated a full twenty-four hours a day; but even on the part-time basis it was an economical comfort. It required the services of a sergeant and three privates whose time cost nothing whatsoever - to operate it, and, based on fuel costs, each man bathed at an expense, to the Red Cross, of less than one cent.

They were handled with military simplicity and expedition. The men, told off into details, entered the first room - the entire outfit was housed in a standardized Red Cross tent of khaki - where they removed their clothes and placed them within the sterilizer, then went direct into the bath. While they bathed their garments were cleansed, sterilized, and dried, and the two functions were so synchronized that the clothes were ready as quickly as the men - and the entire process completed within the half hour.

Return, if you will, for a final minute with Gibson of the Red Cross, up with the Thirty-third Division at the front. I find a final entry in his diary record of his activities nearly three weeks after the signing of the armistice; to be exact, on November 29. It runs after this fashion:

"A couple of days before Thanksgiving I accompanied the Division Graves Registration Officer to the woods north of Verdun where our Division had been heavily engaged during the month of October and where we had quite a list of missing. The fighting had been intense through these woods, portions of them changing hands five or six times in the course of three weeks, and naturally it was impossible to keep careful track of all the brave fellows who fell. Delving into the earth, uncovering rotten corpses, and searching for proper marks of identity is as gruesome and as horrible a job as could be imagined and I must confess my nerve was a bit shattered at the close of the second day. . . ."

Yet not all the work of the Division men of the Red Cross was gruesome and horrible. The war had its humors as 
well as tragedies, major and minor. For instance, how about the job of the Red Cross man with the Seventyseventh Division, when he found himself asked to become stage manager for a troup of seventeen girls - real girls, mind you, none of them the make-believe thing with bass voices and flat feet. He, like many of his fellows, found that the hardest part of his job came after the signing of the armistice, when time hung heavy indeed upon the hands of the doughboys and to keep them occupied was a task worthy of the best thoughts of men - and angels. The mere job of serving coffee and chocolate from the canteens, establishing reading rooms, and distributing cigarettes, magazines, and newspapers ceased to be sufficient. The boys were fairly "fed up" with these things. And with the continued rain and mud and damp of Manonville getting upon the nerves of the Seventh, they demanded something new and mighty good in the way of amusement.

Captain Biernatzki was the Red Cross man with the Division. He quickly sensed the situation, and, taking his little motor car, drove to Toul not far distant, and, as you already know, a Red Cross center of no small importance. He began at once signing up dramatic talent among the American Red Cross girls there in the canteens and the hospitals, and after securing motor transportation for the entire troupe, bore it north to his own Division. The officers of the Seventh were in on the plan and heartily supported it, and as an earnest of their support had the visiting ladies of the Red Cross Road Company No. 1 lunch at a special and wonderful mess on the occasion of their Thespian début.

"One of the girls was a wonderful singer," said Biernatzki afterward in describing the incident. "Another proved a marvel in handling the men, making them sing and keeping them laughing, and there were one or two others, too, who did their bit in a most creditable manner. One of our troupe had brought a clothes basket full of fudge which was thrown out to a forest of waving palms, while the remaining members of the party were sufficiently decor- 
ative and charming to put the finishing touches to the affair by their mere presence."

It seems a far cry from the Red Cross extending succor to a man wounded on the field of battle toward staging a show in a big rest camp, yet I am not sure that the last, in its way, did not do its part toward the winning of the war quite as much as the first.

Of course our American Red Cross was not primarily represented in canteen work in the actual zones of fighting; this function, by the ruling of the United States Army and the War Department, you will perhaps remember, was given almost entirely to the Young Men's Christian Association and to the Salvation Army. There were, however, a few exceptions to this general rule. For instance, at Colombes-les-Belles, an important aviation station, ten or twelve miles south of Toul, I saw a very complete Red Cross equipment at a field camp which at no time was far removed from the front-line fighting. It consisted of a canteen, which served as high as from two thousand to three thousand men a day, and even as late as March, 1919, was still serving from seven to eight hundred; an officers' club, to which was attached an officers' mess, feeding some seventy men a day, and a billeting barracks for the nine Red Cross women stationed at the place. There also was a huge hangar which, with a good floor and appropriate decorations, had been transformed into a corking amusement center. This last was not under the direct charge of the American Red Cross, yet our Red Cross girls were the chief factors in making it go. They danced there night after night with our boys. In fact, in order to have sufficient partners, it was necessary to scour the country for twenty miles roundabout with motor cars and bring in all the Red Cross and Y. M. C. A. girls that were available. It seems that it really is part of a Red Cross girl's job to be on her feet eight hours a day and then to dance full ten miles each night.

This Colombes-les-Belles canteen originally had been 
established in the very heart of the grimy little village, but when the Twenty-eighth (Pennsylvania) Division came to the place on the thirteenth of January, 1919, it took the old canteen structure for division headquarters, but squared the account by building the Red Cross a newer and bigger canteen group in the open field.

"I can't give too much praise to the Red Cross personnel that have been assigned to this particularly isolated spot," the colonel in charge of the flying field told me on the occasion of my visit to it. "I know that the women must have been fearfully lonely out here; but they have never complained. On the contrary, they have given generously and unstintingly of their own time and energies in order that time should not hang heavily upon the hands of the men. The problem of amusement for the aviator is a peculiarly difficult one. He has actually only two or three hours of service each day, and the rest of his waking hours he must be kept ready and fit, mentally as well as physically, for his job, which requires all that a man may possess of nerve and judgment and quick wit. The Red Cross women quickly came to sense this portion of our problem and in helping in its assistance they have been of infinite assistance."

Yet, while service in a field camp such as this at Colombes-les-Belles represents a high degree of fidelity and persistence and, in many, many cases, real courage as well, the real test of high courage for the Red Cross man, as well as for the soldier, came in the trenches or the open fighting, which, in the case of our Yanks, was brought in the final weeks and months of the war to supplant the intrenched lines of the earlier months. Here was a man, a canteen worker for the American Red Cross, who suddenly found it his job to hold the hand of a boy private of a Pennsylvania regiment while the surgeon amputated his arm at the shoulder. War is indeed a grim business. The Red Cross workers in the field saw it in its grimmest phases; but spared themselves many of its worst horrors by virtue of 
forgetting themselves and their nerves in the one possible way - in hard and unrelenting work, night and day. They found unlimited possibilities for service - now as canteen workers and now as ambulance drivers, again as stretcher bearers, as assistants to the over-burdened field surgeons, as couriers or even as staff officers, and fulfilled these possibilities with a quickness, a skill, and a desire that excited the outspoken admiration of the army men who watched them.

I said a good deal at the beginning of this chapter about the Second Division and the work of young Captain Kimball, of Boston, with it. The Second - which was very well known to the home nation across the seas - had an earnest rival in the First, made up almost entirely of seasoned troopers of the Regular Army. And Captain George S. Karr, who was attached to the First, had some real opportunities of seeing the work of the Red Cross in the field, hirnself.

"It was when our Division was on the Montdidier front and preparations were being made for the American offensive against Cantigny," says Captain Karr. "One of the commanding officers called at the outpost station where I made my headquarters and asked if I could get him three thousand packages of cigarettes, the same number of sticks of chocolate, lemons, and tartaric acid for the wounded who would be coming in within the next few hours. It was necessary to deliver these in Chrepoix, where the outpost was located, within twenty-four hours.

"Lieutenant Bero of the outpost station and I went to the Red Cross headquarters at Beauvais, but found that we would have to get the things from Paris and that that would be practically impossible within the time limit. However, we decided to make a try for it, and so left Beauvais in a small camion at 10:30 o'clock in the evening. At a railroad station on the way we had a collision that did for our camion completely. Fortunately there were no serious injuries. We left the disabled car by the roadside about 
halfway to Paris and begged a ride on a French truck that happened along. We reached Paris at $4: 30$ Sunday morning. Red Cross officers had to be aroused and tradesmen routed out - no easy task on a Sunday morning - but we had to have the supplies, and so did it. By 9:30 we had a new camion, already loaded with cigars and cigarettes from the Red Cross warehouse, and lemons and tartaric-acid tablets from the shops of Paris.

"About a quarter of the way back we had trouble with the new camion and had to call for help again. This unpleasant and delaying experience was twice repeated; so that, in fact, the entire load was thrice transferred before it was finally delivered. But - please notice this - the entire camion load of supplies was delivered at Chrepoix - two hours later than the allotted time, to be sure, but still in plenty of time to serve the purpose. Several days later I found two boys in one of the hospitals who told me of their experiences in the Cantigny attack. They spoke of the lemonade and said that they had never before known that lemons and tartaric acid could taste so good to a thirsty man. . . . I think that our trip was worth while."

In July of that same year, 1918, while serving hot drinks, cigarettes, and sandwiches to the American wounded in the field hospital at Montfontain, Captain Karr was severely wounded in the hip by the explosion of an aërial bomb.

In the space of a single chapter - even of enlarged length such as this - it would be quite impossible to trace serially or chronologically the development of the vast field service of our Red Cross. In fact I doubt whether that could be done well within the confines of a book of any ordinary length. So I have contented myself with showing you the beginnings of this work, back there in the districts of the Somme and the Oise at the beginning of the great German drive and have let the men who knew of that service the best - the men who, themselves, participated in it 
- tell you of it, largely in their very own words. And so shall close the long chapter with the war-time story of a man who, like Kimball of Boston, is fairly typical of our Red Cross workers in the field.

The name of this valedictorian is Robert B. Kellogg, and he arrived in France - at Bordeaux, like so many of his fellow workers - on the sixteenth day of July, 1918, reporting at Paris upon the following evening. He came at a critical moment. The name of Château-Thierry was again being flashed by cable all around the world; only this time and for the first time there was coupled with it the almost synonymous phrases of "American Army" and "victorious army." Kellogg - he soon after attained the Red Cross rank of captain - was told of the great need of additional help in handling the wounded which already were coming into Paris in increasing numbers from both Château-Thierry and Veaux, and asked if he could get to work at once. There was but one answer to such a request. That very night he went on duty at Dr. Blake's hospital, out in the suburban district of Neuilly, which had been taken over by the American Red Cross some months before, but which now was being used as an emergency evacuation hospital. For be it remembered that those very July days were the crux of the German drive. In those bitter hours it was not known whether Paris, itself, would be spared. The men and women in the French capital hoped for the best, but always feared and anticipated the worst.

For four fearful nights Captain Kellogg worked there in the Neuilly hospital, carrying stretchers, undressing the wounded, taking their histories, and at times even aiding in dressing their wounds. It was a job without much poetry to it. In fact it held many intensely disagreeable phases. But it was, at that, a fairly typical Red Cross job, filled with perplexities and anxieties and long, long hours of hard and peculiarly distasteful labor. Yet of such tasks is the real spirit of Red Cross service born.

Four to the ambulance came the wounded into that 
haven of Neuilly. Many of them were terribly wounded indeed; and practically none of them had had more attention than hurriedly applied first-aid dressing. But the appalling factor was not alone the seriousness of the wounds, but the mere numbers of the wounded. They came in such numbers that at times during those four eventful July evenings the floors of all the rooms of the hospital - even the hallways and the garage - literally were covered with stretchers. No wonder that the regular personnel of the place, even though steadily increased for some months past, was unable to cope with the crisis. Without the help of Kellogg and eight or nine other emergency helpers from other ranks of the American Red Cross it is quite possible that it would have collapsed entirely.

Captain Kellogg's emergency task at Neuilly ended early in the morning of the twenty-second; but there was no rest or respite in sight for him. That very day a Red Cross captain stopped him at headquarters and asked him if he was free.

"I guess so," grinned Kellogg.

"Then come out to Crépy and help us out," said the other American Red Cross man. "We're in a good deal of a mess there."

"All right," was the reply. "I'm ready whenever you are."

He grinned again. He realized his own predicament. $\mathrm{He}$ had not yet been assigned to any definite department; in fact, although he had given up his precious American passport, he had not yet received the equally precious " Red Cross Worker's Card," which was issued to all the war workers in France and which was of infinite value to them in getting about that sentry-infested land. He had no more identification papers than a rabbit and realized that he might easily find himself in a deal of trouble. Yet within the half hour he had packed his small musette and grabbing up two blankets was on his way in an automobile toward the 
front. He reached Crépy at about six o'clock that evening and reported to Major Brown, of the Red Cross.

"He was called major," says Kellogg, as he describes the incident, "but he wore nothing to indicate his rank and I never did find out just what he was. He left for Paris the following day to get supplies, but he never returned, nor did I hear from him again. There was nothing for us to do that night and absolutely no provision for us. We obtained coffee from a French Army kitchen and slept in a wheat field in the rain, with our sole shelter a bit of canvas tied to the rear of our car."

There may be folk who imagine that war is all organization - certain historians seemingly have done their best to create such an illusion. But the men who have been upon the trench lines.and in the fields of open battle know better. They know that even well-organized armies, to say nothing of the Red Cross and other equally well-organized and disciplined auxiliaries, cannot function at the fullness of their mechanical processes in the super-emergency of battle. There it is that individual effort regains its ancient prestige and men are men, rather than the mere human units of a colossal organization. Yet brilliant as individual effort becomes, all organization is rarely lost. And so Kellogg, in the deadening rain of that July night, found the situation at Crépy about as follows: Two American evacuation hospitals - Numbers Five and Thirteen and a French one, located in the thick woods some four miles distant from the town, which in turn was used as an evacuating point for all of them - this meant that the patients were brought in ambulances from these outlying hospitals to Crépy and there placed on hospital trains, bound for Paris and other base-hospital centers. The theory of such operation is both obvious and good. But in the super-emergency of the third week of July, 1918, theory broke down under practice. The evacuation hospitals in the woods received newly wounded men in such numbers that they were obliged to clear those who had received their 
first aid dressings with an unprecedented rapidity. And this rapidity was quite too fast for the limited facilities of the hospital trains ; which meant congestion and much trouble at the Crépy railhead - which was the precise place where Captain Kellogg of our American Red Cross found himself early in the morning of the twenty-third day of July.

"There was I," continues Kellogg, as he relates the narrative of his personal experiences, "with Brown gone to Paris and no instructions whatsoever left for me. But I didn't need any instructions - not after that first bunch of wounded fellows came up there to the railhead - at just a little before noon. There were perhaps three hundred of them, and while they were waiting for the hospital trains they lay there in the open - and it was raining - their stretchers in long rows, resting on the cinders alongside the railroad tracks. I had secured a supply of cigarettes, sweet chocolate, cookies, and bouillon tubes from a stock left by Brown. I made a soup for the men and, with the help of some of the litter bearers, distributed it and did what else I could for their comfort. When the train came in and it was time to move the wounded upon it, we found that we did not have nearly enough stretcher bearers. So I went into the town and recruited a number of volunteers among the soldiers - including several officers. That night I left my supplies in the office of the French Railway Transport officer in the station and, with a stretcher for a bed, found a place to sleep in what had been left of a bombed house."

Let Captain Kellogg continue to tell his own story. He is doing pretty well with it:

"The next day, Field Hospital No. 120 arrived and set up part of its tents - sufficient to give protection for all patients thereafter who had to wait for the trains. Medical and orderly attention was amply provided after that, but the food supply, even for the officers and personnel of the hospital company, was very limited and the soup 
that I was able to make from the bouillon cubes proved a blessing.

"For several days the wounded passed through this point at the rate of several hundred a day, and every man received what he wanted from the Red Cross stock available. Hospital trains from other points sometimes stopped at Crépy. When this happened I always boarded them and, with the help of two enlisted men, distributed cigarettes and cookies. On about my fifth day there the number of wounded being evacuated through that railhead and the officers and personnel of its field hospital company were ordered to one of the neighboring evacuation hospitals. Because of the greatly reduced number of workers, our tasks were therefore rendered much harder, even though the number of wounded had been somewhat decreased. Our own comfort was not particularly increased. We moved into a small tent which was fairly habitable, although it was both cold and rainy nearly every day. I remember one night when it rained with such violence that the tent floor became flooded. I awoke to find the stretcher on which I was sleeping an island and myself lying in a pool of water. On two occasions we were bombed at night."

All these days Kellogg was trying to get Red Cross headquarters at Paris on the long-distance telephone. But all France was particularly demoralized those last days of July; and the telephone service, never too good under any circumstances, was gloriously bad. So after several attempts to talk with headquarters and get some sort of instructions and help, he decided that he would have to go there; which was easier said than done. For remember that this Red Cross man had no credentials; in fact, no identification papers of any sort whatsoever. While travel in France in those days, and for many, many days and months thereafter, was rendered particularly difficult and almost impossible by strict regulations which compelled not only the constant display of identification papers but a 
separate and definite military travel order for each trip upon a railroad train. Which in turn meant that it would be fairly suicidal for Kellogg to attempt to go into Paris by the only logical way open to him - by train. It was more than doubtful if he would have been able to even board one of them. For at every railroad station in France stood blue-coated and unreasoning poilus whose definite authority was backed by the constant display of a grim looking rifle in perfect working condition.

So Kellogg walked to Paris, not every step of the way, for there were times when friendly drivers of camions gave him the bumping pleasure of a short lift. But even these were not frequent. Travel from Crépy to Paris at that particular time happened to be light. Still, after a night at Senlis, in which he slept stretched across a table in a café, he did manage to clamber aboard a truck filled with French soldiers and bound straight for their capital.

One might reasonably have expected an ordinary sort of man to have been discouraged by such an experience, but a good many of our Red Cross men over there were quite far removed from being ordinary men. And so Kellogg, after a few days of routine office work at headquarters, insisted upon his being given an outpost job once again. And soon after was dispatched to the little town of La Ferte upon the Marne, not many miles distant from Château-Thierry. This time he had his working papers; to say nothing of the neat document which told "all men by these presents" that he was a regular second lieutenant of the American Red Cross. His upward progress had begun.

He waited several days at the American Red Cross warehouse at La Ferte, during which time he had the opportunity of studying boche aërial bombardments - at extremely short range. Then he was forwarded to the outpost at Cohan, conducted by Lieutenants Powell and Leighton as partners. I may be pardoned if I interrupt Kellogg's 
narrative long enough to insert a sentence or two about Powell. In some ways he was the most remarkable of Red Cross men. Handicapped by a deformity, he stood less than four feet and a half high, yet he was absolutely without fear. Hard test showed that. The officers and men of the Twenty-eighth Division with whom he had stood during the acid-test days on the drive at Château-Thierry called him, pertinently and affectionately, "General Suicide."

Cohan stood about five miles back from the front-line trenches and so was under frequent artillery fire. The Red Cross outpost there was in a partly demolished structure, one of the rooms of which had been used as a stall and contained the body of a dead horse which could not be gotten out through the door. It served that same Twentyeighth Division with whom Powell made so enviable a reputation.

The confusion that had prevailed at Crépy was, happily, missing at Cohan. Powell and Leighton not only had an excellent stock of Red Cross supplies, which were replenished twice a week from the La Ferte warehouse, and a camionette in good order, but they had a systematic and orderly method of distribution. As Kellogg worked with them he studied their methods - it was a schooling of the very best sort for him. And he, seemingly, was an apt scholar. On the twenty-first of August a Red Cross man named Fuller, with supplies bound for the neighboring outposts of Dravigny and Chéry, stopped at Cohan and asked Kellogg to ride on with him. The course of study of " the game "was about completed. Kellogg had been in actual Red Cross service for a full month - which in those days made him a regular veteran. Fuller held a note from his commanding officer which stated that if a driver could be assured the camionette upon which he rode would be assigned to Chéry and Dravigny.

Thus was Red Cross Kellogg's next job set out for him. He had never driven a Ford. But other folks have mastered such a handicap and Kellogg had driven many real 
automobiles, and so went easily to the new job, with such rapidity and skill that before the next night he was in sole charge of the little camionette and driving it with professional speed over the steel-torn battlefields and roads of the entire Château-Thierry district.

Dravigny and Chéry shocked and fascinated him. At the first of these two towns our Red Cross men in charge were quite comfortably situated. They occupied a house in very fair preservation which was situated in a lovely garden and had large and bright rooms for living and for working. But Kellogg remembers Chéry Chartreuve as a " hell hole."

"I can think of no better words with which to describe it," he says. "Not a building with all four walls and a roof remained in all the town. The débris of fallen walls and discarded military equipment clogged the streets. Refuse and filth were everywhere. The sanitary arrangements - well, there hadn't been any. The odor of dead horses filled the air. Flies? There are no words to describe the awfulness of the flies. Our own artillery .75 's and $.15 \overline{5}$ 's - surrounded the town in addition to occupying positions at each end of it and in its center. The roar of these guns was continuous, the concussion tremendously nerve-racking, while the presence of this artillery made the village a target for the enemy guns. It was shelled day and night. And during the nights the boche seemed to take an especial delight in filling the town with gas.

"Sleep was almost impossible. We had in one night five gas alarms, in each case the concentration being sufficiently strong to necessitate the gas masks. The dressing station was next to our sleeping quarters. It was covered with gassed and exhausted doughboys who had crept in there in search of shelter. At frequent intervals the ambulances would arrive with fresh loads of wounded. The whistle and explosion of shells was constant. A battery of .155's in our back yard nearly lifted us from our cots each 
time it was fired. Once I got a dose of gas sufficient to cause the almost complete loss of my voice and a throat trouble that lasted for weeks."

Yet under conditions such as these, if not even worse, Kellogg and his fellows worked - all day and usually until ten or eleven o'clock at night. Their supplies went to the boys in the lines. This was not only ordinarily true, but at Chéry, particularly so. The Seventy-seventh Division had moved in close to the town, and on the twenty-ninth of August, while the Red Cross workers were pausing for a few minutes to catch up a snack of lunch, a shell landed plumb in front of their outpost building. Its fragments entered the doors and windows and perforated several of their food containers. Sugar, coffee, cocoa - all spilled upon the floor.

The room was filled with men - soldiers as well as Red Cross - at the moment. None was hurt. With little interval a second shell came. This time two men who had taken refuge in a shed that formed a portion of the building were killed. There was seemingly better shelter across the street. To it the doughboys began running. Before they were well across the narrow way, the third boche visitor descended. It was a deadly thing indeed. Thirty-eight American lives were its toll. Eleven lay dead where they dropped. The others died before they could reach the hospital, while the escape of the Red Cross men was little short of providential.

The station had to be abandoned at once. The Red Cross moved back to Dravigny in good order, and what was left of miserable Chéry Chartreuve was speedily obliterated by the Germans.

The record of Captain Kellogg's experiences with our Red Cross in France reads like a modern Pilgrim's Progress. Our Christian who found himself in khaki was quickly moved across the great checkerboard of war. On one day he was reëstablishing the Chéry outpost at the 
little town of Mareieul, from which point the Seventyseventh could still be served, but with far less danger; on the next he was far away from the Seventy-seventh and at the little French town of Breny, at the service, if you please, of the Thirty-second Division, United States Army. The Seventy-seventh had been chiefly composed of New York State boys; they wore the Statue of Liberty as an army insignia upon their uniforms. The Thirty-second came from the Middle West - from Wisconsin and Michigan chiefly. It had been in the lines northwest of Soissons - the only American Division in the sector - and there had coöperated most efficiently with the French. Its regiments were being used there as shock troops to capture the town of Juvigny and territory beyond which seemingly the tired French Army was quite unable to take. They were accomplishing their huge task with typical American brilliancy, but also in the American war fashion of a heavy loss of precious life. Because of the isolation of the Thirty-second from the usual American bases of supply it became peculiarly dependent upon our Red Cross for its tobacco and other creature comforts, responsibility which our Red Cross regarded as real opportunity. In addition to the ordinary comforts it ordered some four thousand newspapers each day from Paris, which were enthusiastically received by the doughboys. And you may be assured that these were not French newspapers. They were those typically Parisian sheets in the English language, the New York Herald, the Chicago Tribune, and the London Mail.

Thereafter and until long weeks after the signing of the armistice Kellogg remained with the Thirty-second, but did not cease his Pilgrim's Progress. For the Division moved; here and there and everywhere. For several weeks it was at Vic-sur-Aisne, while Red Cross Kellogg - who by this time was a real Ford expert - was making hot chocolate in a huge cave that once had been an American division headquarters. Then it moved to a new sector, not far from Bar-le-Duc, and Kellogg moved with it. In the meantime 
he had performed temporary work at Neufchâteau - always an important division headquarters of the American Red Cross - at Bar-le-Duc and at Rosnes; but these jobs were merely stop-gaps - the real task was forever at the front lines. And when, on the twenty-fourth of September, Kellogg came up with his Division at Wally, he was ready for hard fighting once again. So was the Thirty-second. It was moving forward a little each day and in fact was already considered "in reserve" on September 26 - the day of the beginning of the great Argonne offensive. Two days later, with a borrowed army truck and an American Red Cross camionette - both filled with supplies to their limit - Kellogg and two of his Red Cross associates moved forward nine miles to the Avecourt Wood and there joined the Sixty-fourth Brigade of the Division. The brigade commander furnished them with an old dugout - which for nearly four years past had formed a part of the French trench system. After their supplies had been dumped into the place there was just room left for the bedding rolls of the Red Cross men, and even these overlapped one another. It rained steadily for several days and the mud upon the floor of the dugout became entirely liquefied. At night water came in through the doorway and trickled in innumerable sprays down from the roof. The men lived in mud knee-deep. Oh, it was some fun being a Red Cross man at the front in those days of actual fighting! But the fun was some distance removed from those popular reports of "the Battle of Paris" which used to come trickling back to America for the edification and joy of the folk who stayed behind. It was prunes and preserves being a Red Cross worker in France in those autumn days of 1918. Only the trouble was that no one ever could find the prunes or the preserves.

On the thirtieth day of September, the Thirty-second moved from the Avecourt Woods to those of Montfaucon and assumed a military position of "support."

"The intervening country had been No Man's Land for 
four years and the condition of the roads can only be imagined," says Captain Kellogg. "We followed the troops, who left at about eleven o'clock that morning, but were soon caught in that tremendous congestion that existed on all the roads during the first days of the drive. By dark we were still on the road, having progressed less than two miles. We finally became hopelessly stuck, being stalled, and were obliged to remain stuck throughout the night. During the day we had given out many packages of cookies to the tired and hungry men along the road. Many times since the soldiers have spoken to me in appreciation of those cookies. That night was one of the most uncomfortable experiences that I had in France. It was so cold that we could not keep warm. This, coupled with the occasional whine of incoming shells, prevented sleep, although frequently we threw down our bedding rolls at the side of the road and attempted it.

"In the morning we found a number of ambulances among the other stalled vehicles. For more than fortyeight hours they had been on the road with their wounded and neither drivers nor patients had been able to obtain much of anything to eat or drink. We supplied them with cookies and gave them what water we had in our canteens. Two of the wounded had died during the night. Two others were unconscious and another was delirious. The congestion ahead of us on the road that morning seemed as bad as ever. Finally we managed to get out of that road entirely, making a fresh start by a longer but less crowded way. At dusk that first day of October found us still quite a distance from our Division. We spent that night with some Signal Corps men in the cellar of a shell-shocked building in Varennes. The following morning we succeeded in reaching our destination and located ourselves with several enlisted men of the Forty-third Balloon Company in a dugout which until a few days before had been occupied by German officers.

“This place was interesting. Reached by a steep flight 
of steps, it was sunk fully fifty feet below the surface. It consisted of three rooms and a kitchen, the walls of each nicely boarded and the whole comfortably, if roughly, finished.

"The combat regiments and battalions of our army were all around us in the woods. We continued serving them. On the morning of the third I drove back to Froidos for fresh supplies. Upon my return I found that the troops of our Sixty-fourth Brigade were already on the road, moving toward the town of Véry. We knew what this meant - that in the morning they were going into the front lines and probably over the top. We quickly unloaded cookies and cigarettes from the car and, standing by the roadside in the dark, handed a supply of each to every soldier who passed by.

"The troops went into the lines at Epinonville before daybreak on the morning of the fourth of October. Lieutenant McGinnis of the Red Cross and I arrived there about noon. Never shall I forget it. The battle lines lay just a little way ahead of us. Machine guns still occupied the town which then was under violent bombardment. In fact during the entire three weeks that we made our headquarters at Epinonville there was not a single day or night that the town was not subjected to shell fire.

"Our boys had made a first attack early in the morning of the fourth. All that morning the wounded had been returning - in large numbers. Some of them were brought to regimental dressing stations of the 128th Infantry, but the majority were handled at that of the 127th. It was here that we did most of our work during the next few days. The station was in a sort of dugout, made of boards and builded into a sidehill. In the ditch beside it a sizable salvage pile had materialized already, clothing and bandages - both blood-soaked, rifles, shoes, helmets, mess kits, here and there a hand or a foot. On the ground, lying on stretchers, were a number of wounded men waiting for the ambulances that would take them to the field hos- 
pitals. All about were soldiers; slightly wounded, gassed, shell-shocked, or just plain sick or exhausted. Down the road could be seen a bunch of prisoners just captured that morning. On its opposite side lay the bodies of several of our fellows who had just died, while across the fields beyond stretched slow-moving, irregular processions of litter bearers, bringing in their burdens of wounded men.

"Such were the scenes and conditions that greeted us in Epinonville. There was work a-plenty awaiting us, and we lost no time in taking possession of a shack for our outpost of the American Red Cross. We quickly unpacked our supplies and moved into it. McGinnis had a rather formidable job of making some twenty gallons of cocoa, while I, equipped with cookies, cigarettes, and canteens filled with water, did what I could for the wounded in and around the dressing station.

"Late in the afternoon it became necessary for me to return to our dugout in the woods for supplies which we had been unable to bring in on the first trip. So, leaving McGinnis to take care of the dressing stations, I started back, taking with me a load of wounded men for whom no ambulance was available. Our route took us over a dilapidated plank road through the narrow valley between Epinonville and Véry. We had covered perhaps half of this road when Fritz began a bombardment of the valley which lasted fully fifteen minutes. A French artillery outfit was moving ahead of us at a snail's pace and we could not pass it because of the narrowness of the road. Some of the shells were breaking close at hand, showering the car with shrapnel and fragments, but there was no way I could remove the wounded to a place of safety. There was nothing to do but pray for luck and keep going as fast as the slowmoving artillery ahead would permit. Several men within our sight were hit during those fifteen minutes, but fortune favored us. Not one of our men was even scratched and I delivered my load safely at the triage at Véry.

"Arriving at Epinonville late that evening I worked at 
the dressing station most of the night, serving hot cocoa, cookies, and cigarettes to the wounded and the men who were working for their comfort. During these first days there was hardly any food, and the doctors worked continuously day and night with only such sleep as they could snatch for a few minutes at a time.

"During the sixteen days that the Division was in the front line after we went into Epinonville, our first attention was given to the dressing stations and the wounded. As fast as new stations were opened at farther advanced points, we reached them with our cocoa and cookies. The ordinarily simple task of making cocoa became, under the conditions which we faced, a huge job. We usually made enough at a time to fill our four five-gallon thermos containers and almost always we had to do the work ourselves. Water was always scarce and to get enough of it was a problem. Wood had to be cut and fires made and handled with the utmost caution so that no smoke would show.

"Other conditions aside from the danger that constantly threatened were equally difficult. The weather was awful - cold and rainy, with deep mud everywhere. Eating was an uncertain and precarious proposition. The shack that we called home was - well, you would hesitate to put a dog in it in normal times.

"Our most interesting work generally was done under the cover of darkness. For instance, there came a night when we particularly wanted to reach Company $\mathrm{K}$ of our 128th Infantry. One of its cooks offered to go with us as guide, and so, with our car loaded with hot cocoa, cookies, cigarettes, sweet chocolate, and chewing tobacco, we left Epinonville shortly after dusk. A mile or so out we diverged from the road, our route then taking us across the shell-torn fields, with only a faint footpath to follow. Of course no light was possible and a blacker night there never was. Tommy - the company cook - and McGinnis walked immediately in front of the car indicating the course I should take. We continued thus until we had 
penetrated beyond some of our machine-gun positions. Ahead of us and back of us and all around us shells were bursting. The sing of machine-gun bullets was in the air. Our mission seemed hopeless, but we knew that those boys of Company $\mathrm{K}$ had been lying in the shell holes and the shallow dugouts for two long days with little to eat, drink, or smoke. We determined to reach them. Star shells were lighting the fields ahead of us, and finally we dared not proceed farther with the car for fear it would be seen and draw fire. Figuring that we could get a detail of boys to come back for the cans of cocoa and other things, we left the car in the lee of a hill and went ahead on foot, taking with us what we could carry in our pockets and sacks. K Company had shifted its position, however, and we could not locate it. We distributed the stuff we had with us to the soldiers we passed and then returned to the car. Here we sought out the officers of the outfits lying nearest us and gained their permission to let the men - a few at a time come to the car, where we served them until our stock was exhausted. Most of these men were from the 127th. Some were from a machine-gun battalion. These boys for several days had been dependent upon their ' iron rations.' Mere words cannot express their appreciation of our hot cocoa and other things. I recall that our chewing tobacco made a great hit with them. They could not smoke after dark and welcomed something that would take the place of smoking."

Enough of the incidental detail of the Red Cross worker. I think that you have now gained a fair idea of what his job really was; of not alone the danger that it held for him at all times, but the manifold discomforts, the exposure, the almost unending hours of hard, hard work. Multiply Red Cross Kellogg by Red Cross Jones and Smith and Brown and Robinson - to the extent of several hundreds - and you will begin to have only a faint impression of the magnitude of concerted work done by the men of our American Red Cross in the battlefields of France in those 
fall and summer months of 1918. A good deal has been written about the Red Cross woman - before you are done with this book I shall have some more things to say about them, myself. A word of praise at least is the due of the Red Cross man. They are not the shirkers or the slackers that some thoughtless folk imagined them - decidedly not. They were men - generally well above the army age of acceptance, even as volunteers - who found that they could not keep out of the immortal fight for the freeing of the liberty of the world.

Take the case of Lieutenant Kellogg's right-hand man now Captain McGinnis. He was a Coloradian and nearly fifty years of age when the United States entered the World War. He is not a particularly robust man, and yet when we finally did slip into the great conflict, it was this Red Cross McGinnis who recruited an entire company of infantry for the Colorado National Guard and was commissioned a first lieutenant in it. When the National Guard was made a part of the Federal Army, McGinnis was discharged. He was too old, they said.

The man was nearly broken-hearted; but his determination never wavered. He was bound to get into the big fight. If the army would not have him there might perhaps be some other militant organization that would. There was. It was the Red Cioss - our own American Red Cross if you please. And what McGinnis, of Colorado, meant to our Red Cross you already have seen.

Multiply the McGinnises as well as the Kelloggs and you begin once again to get the great spirit and power of the Red Cross man. Danger, personal danger? What mattered that to these? They consecrated soul and spirit, and faced danger with a smile or a jest, and forever with the sublime optimism of a youth that will not die, even though hair becomes gray and thin lines seam the countenance. And now and then and again they, too, made the supreme 
sacrifice. The American Red Cross has its own high-set honor roll.

After the signing of the armistice, Kellogg's beloved Thirty-second Division was one of those chosen for the advance into the Rhineland countries. It had fairly earned this honor. For in those not-to-be-forgotten twenty days of October that it had held a front-line sector, it had gained every objective set for it. Therefore it was relieved from active duty on the twentieth and sent back to the Véry Woods in reserve. But Kellogg and his fellows were not placed " in reserve" - not at that moment, at any rate.

They found "their boys" tired and miserable, living in the mud in "pup tents," and greatly in need of Red Cross attention and assistance. Finally, on the twentyeighth and under the insistence of their commanding officers, Kellogg and McGinnis went back to Bar-le-Duc for five days of rest. They needed it. There was a Red Cross bathing outfit at Bar-le-Duc, and the two men needed that also. It had been more than six weeks since they had even had an opportunity to bathe.

Armistice Day found the Thirty-second in actual fighting once again and Kellogg and McGinnis with it - by this time one might almost say "of course." It was located in and about Ecurey and kept up the fighting until the fateful eleven o'clock in the morning set for the cessation of hostilities. The Division remained at Ecurey for just a week after the signing of the armistice. Then it began its long hike toward the east, passing through Luxembourg and down to the Moselle at the little village of Wasserbillig, where it arrived on the twenty-ninth day of November.

Kellogg, McGinnis, and some other of our Red Cross men - to say nothing of a big Red Cross truck kept with it. While it had been assumed by the Paris headquarters of the American Red Cross that it would be 
impossible to serve the boys on their long march into the occupied area and so no provision was made for the forwarding of comfort supplies, as a matter of actual fact there was a good deal that could be done - and was done.

In such a situation was Red Cross opportunity, time and time and time again. And if Paris for a little was neglectful of the fullness of all of it, our Red Cross men who were at the Rhine were not - not for one single moment. They were on the job, and, with the limited facilities at hand, more than made good with it. One single final incident will show:

On the morning that the Thirty-second swung down into Wasserbillig from the pleasant, war-spared Luxembourg country and first entered Prussian Germany, the Red Cross men with it found that two of their fellows - Lieutenants R. S. Gillespie and Robert Wildes - were already handling the situation. These men had previously been engaged in similar work at Longwy, and had been sent forward with a five-ton truck, loaded with foodstuffs, for such returning prisoners - and there were many of them - as the Thirty-second might encounter on its eastward march. Under Lieutenant Gillespie's direction a canteen already was in operation at the railroad station there in Wasserbillig. Equipped with a small supply of tin cups, plates, and the like - to say nothing of several stoves - it was serving soup, bread, jam, beans, bacon, corned beef, and coffee. The prisoners (soldiers and civilians - men, women, and children, and many of them in a pitiable condition) came through from Germany on the trains up the valley of the Moselle. They had a long wait, generally overnight, in Wasserbillig. And there the American Red Cross fed them by the hundreds, and in every possible way ministered to their comfort.

It saw opportunity, and reached to it. It saw a chance of service, and welcomed it. The record of its welcome is 


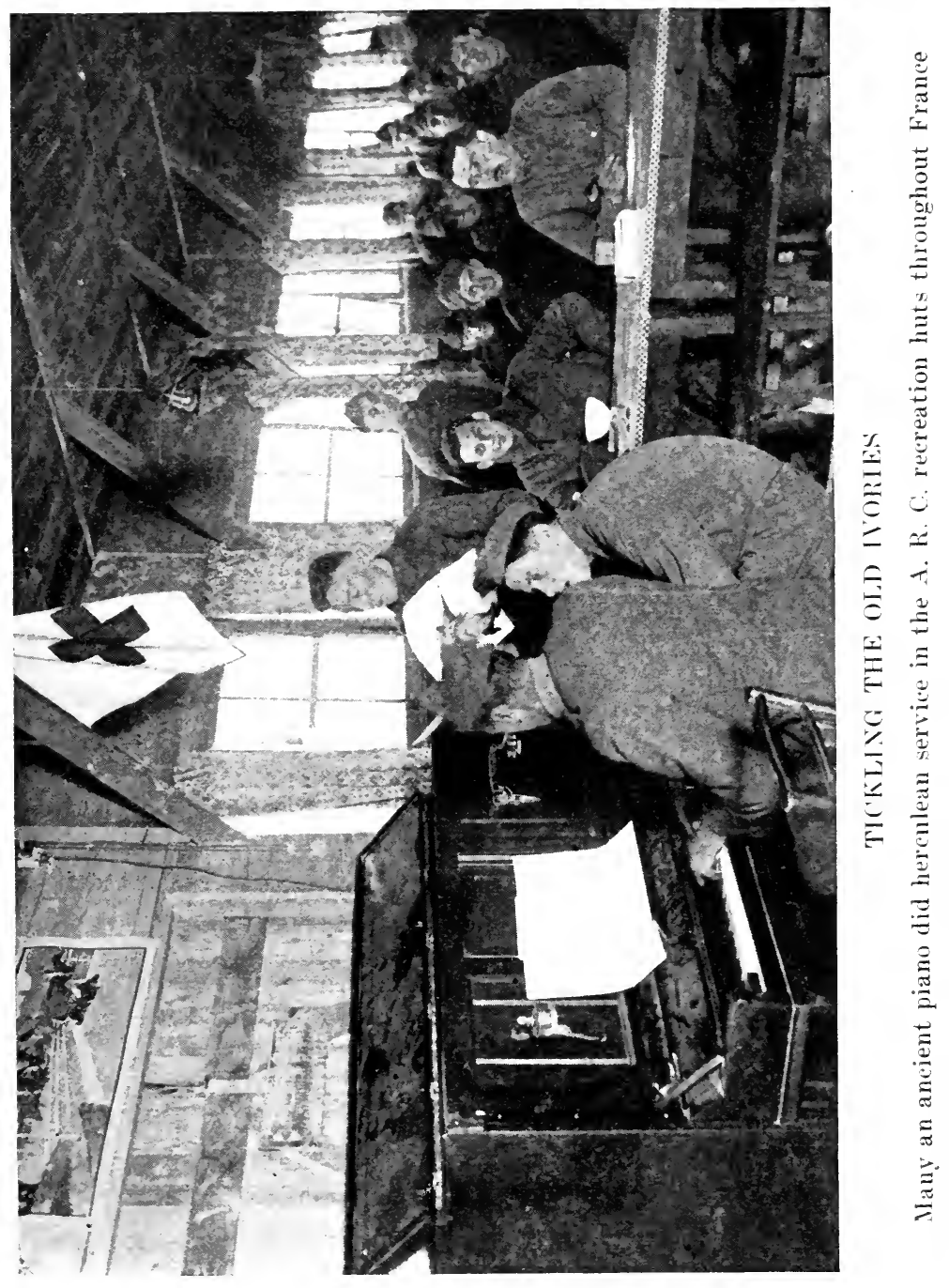




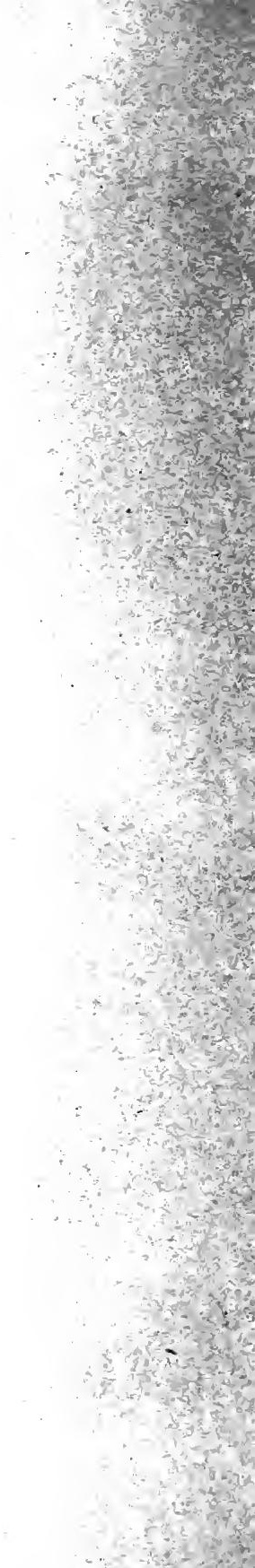


written in the hearts and minds and memories of the boys who marched down the valley of the Moselle, through Treves and Cochem, to Coblenz. From those hearts and minds and memories they cannot easily be erased. 


\section{CHAPTER VIII}

OUR RED CROSS PERFORMS ITS SUPREME MISSION

FTER all is said and done, what is the supreme pur-
pose of the Red Cross?

I think that any one who has made even a cursory study of the organization - its ideals and history - should have but little hesitancy in finding an answer for that question. Despite its genuine achievement in such grave crises as the San Francisco earthquake and fire, for instance, its real triumphs have almost always been wrought upon the field of war. And there its original mission was definite - the succoring of the wounded. That mission was quite as definite in this Great War so lately ended as in the days of Florence Nightingale and Clara Barton. The canteen work of our Red Cross in the past two years for our boys who came and went across France and Germany was interesting and important; its field work, which you have just seen, even more so. Yet its great touch - almost, I should say, its touch divine - came not merely when the boys traveled or when they went upon the field of battle, but rather when the iron hand of war cruelly smote them down. Then it was that our Red Cross was indeed the Greatest Mother in the World - the symbolic spirit of its superb poster most amply realized, in fact.

The hospital work of the American Red Cross in France, particularly in its medical phases as distinct from those more purely of entertainment, was, in the several successive forms of organization of the institution over there, known as the Medical and Surgical Division or Department, although finally as the Bureau of Hospital Administration. In fact it was almost the only department of our Red Cross in France which did not, for one reason or another, undergo reorganization after reorganization. This, 
in turn, has accounted for much of its efficiency. It was builded on a plan which foresaw every emergency and from which finally the more permanent scheme for the entire Red Cross was drawn.

"We divided our job into three great steps," the man who headed it most successfully told me one day in Paris. "The first was to meet the emergency that arose, no matter where it was or what it was; the second was to perfect the organization, and the third and final step was to tell about it - to make our necessary reports and the like."

A program which, rigidly set down, was rigidly adhered to. Remember, if you will once again, that under the original organization of the American Red Cross in France there were two great operating departments side by side; one for military affairs, the other for civil. In those early days the Department of Military Affairs grouped its work chiefly under the Medical and Surgical Division which was headed by Colonel Alexander Lambert, a distinguished New York physician who then bore the title of Chief Surgeon of the American Red Cross. It was this early division which planned the first of the great American Red Cross hospitals in France, of which very much more in good time.

In January, 1918, this Medical and Surgical Division became known as the Medical and Surgical Section of the Department of Military Affairs, while Captain C. C. Burlingame, a young and energetic doctor who had met with much success in the New England manufacturing village of South Manchester, Connecticut, became its guiding head. Of Captain Burlingame - he attained the United States Army rank of lieutenant colonel before the conclusion of the war - you also shall hear much more. It would be quite difficult, in fact, to keep him out of the pages of this book, if such were the desire. One of the most energetic, the most tireless, the most efficient executives of our Red Cross in France, he accomplished results of great brilliancy through the constant use of these very 
attributes. Within six months after his arrival in France he had risen from first lieutenant to the army rank of captain, while his real achievements were afterward recognized in decorations by the French of their Médaille d'Honneur and by the new Polish Government of its precious Eagle.

In these weeks and months of the first half of 1918, Burlingame found much of his work divided into several of the functions of the Department of Civil Affairs - particularly among such sectors as the Children's Bureau, the Bureau of Tuberculosis, and the Bureau of Refugees. This was organization business. It took strength from that very arm of the Red Cross which soon was to be called upon to accomplish so very much indeed. And when, on the twenty-fourth of August, 1918, the Gibson reorganization plan divorced the Medical and Surgical Section entirely from the work of the Department of Civil Affairs and combined its entire activities into a Medical and Surgical Department, Burlingame and his fellows had a free hand for the first time, a full opportunity to put their tripartite policy into execution.

For a time Colonel Fred T. Murphy was director of this newly created department. On January 6, 1919, however, he was succeeded by Colonel Burlingame, who had been so instrumental in framing both the policies and carrying out the actual operations of the department. On that same day the former Medical and Surgical Section of the Department of Military Affairs became the Bureau of Hospital Administration. The Bureau of Tuberculosis was transferred as such to this new department, as was also the Children's Bureau. The Women's Bureau of Hospital Administration which, under the old organization, was reporting to the general manager, became the Bureau of Nurses, while the work for the mutilés, which was being conducted by both the departments of Military Affairs and Civil Affairs, was relegated to a new bureau.

I have given these changes in some detail not because 
they were in themselves so vastly important, as because they tend to show. how firm a grasp Burlingame gained not only on the operations but upon the very organization of his work. He did not reorganize; he perfected, and finally was able to perfect even the Gibson general plan of organization for our Red Cross in France which was recognized as the most complete thing of its sort that had been accomplished.

For the purpose of better understanding the activities of this bureau, it may be well to divide its activities into four great classes. The first of these would group those activities conducted directly by the Surgeon General's office of the United States Army, but to which our Red Cross gave frequent aid in the line of supplies, supplementing those normally furnished through the usual army channels. Sometimes not only supplies but personnel was furnished. Such aid was given upon request of army officers.

Under the second grouping one finds those great hospitals, in most cases established by the American Red Cross while the medical and surgical plans of our army were still forming and were in a most unsettled and confused state. These were known, even after the Surgeon General had taken them under his authority, as American Red Cross Military Hospitals. They were then operated jointly by the United States Army and our Red Cross; the army being usually responsible for the scientific care and discipline of the organization, while our Red Cross took upon its shoulders both the actual business management and the supplying of the necessary materials.

The third and fourth groupings are smaller, although, in their way, hardly less consequential. In the one were the American Red Cross Hospitals which were operated purely for military purposes and for which the American Red Cross assumed the full responsibility of operation, while in the other were the hospitals, infirmaries, and dispensaries which were operated by the Ried Cross - in some few cases jointly with the other organizations - for the benefit of 
civilians, including several thousand American civilian war workers who found themselves in France during the past two years.

If I have bored you with these details of organization it has been to the direct purpose that you might the better understand how this important phase of Red Cross operation functioned. Now, for the moment, forget organization once again. Go back to the earlier days of our Red Cross in France - the days of Grayson M.-P. Murphy and James H. Perkins and their fellows.

None of these men either realized or fully understood either the importance or the overwhelming size to which the hospital function of the United States Army would attain before our boys had been in actual warfare a full year. The army itself did not realize that. Remember that for many weeks and even months after Pershing had arrived in Paris its hospital plans were in embryo. In this situation our Red Cross found one of its earliest opportunities, and rose to it. With Colonel Lambert - he then was Major Lambert - in charge of its Medical and Surgical Division it began casting about to see how it might function most rapidly and most efficiently.

To the nucleus of the army that began pouring into France in the early summer of 1917, it began the distribution of emergency stores - a task to which we already have referred and shall refer again. It hastily secured its own storerooms - in those days quite remote and distant from the American Relief Clearing House and the other general warehouses of the American Red Cross - and from these in July, 1917, sent to 1,116 hospitals, practically all of them French, exactly 2,826 bales of supplies. In December of that same year it sent to 1,653 hospitals - including by this time many American ones - 4,740 bales of similar supplies. It was already gaining strength unto itself.

Surgical dressings formed an important portion of the contents of these packages Our Red Cross did not wait 
upon America for these; the huge plan for standardizing and making and forwarding these from the United States was also still in process of formation. It went to work in Paris, and without delay, so that by the end of 1917 two impressive manufacturing plants were at work there - one at No. 118 Rue de la Faisandre, where 440 volunteer workers and a hundred paid workers were averaging some 183,770 dressings a week, and a smaller establishment at No. 25 Rue Pierre Charron, where a hundred volunteer and ninety paid workers were at similar tasks. Eventually a third workroom was added to these. And it is worth noting, perhaps, that immediately after the signing of the armistice these three workrooms were turned into manufactories for production of influenza masks, for which there was a great emergency demand. In three weeks they turned out more than 600,000 of them.

The hospitalization phases of the Medical and Surgical Department of our Red Cross over there were, of course, far more difficult than those of the mere production or storage of dressings and other medical supplies. And they involved a vast consideration of the human factors of the super-problem of the conflict.

"In this war there were two kinds of fellows," Colonel Burlingame told me one evening in Paris as we sat talking together, " the ones who went over the top and those who didn't. It was up to the second bunch to look out for the first - at every time and opportunity, which brings us squarely to the question of the French hospitals, and the American soldiers who woke up to find themselves in them. You see the Red Cross was just as responsible for those fellows as for the ones who went directly into our own hospitals over here. The French authorities told me not to worry about those boys. "We will take very good care of them,' they said, and so they meant to do. 'Who will take care?' I asked them in return.

"I went straight to one of the chief surgeons of their 
army. I put the matter to him as plainly as I could. 'You are the best ever,' I said to him, 'but - don't you see? - you are tired out. We want to help you. Can't we? Won't you let us loan you nurses and other American personnel as you need them?'

"Would they? Say, the French fell for that suggestion like ducks, and we sent them thirty or forty girls, just as a beginning.. Can you think of what it would mean for one of our Yankee boys wounded in a French hospital and perhaps ready to go on an operating table to lose an arm or a leg and then finding no one who could speak his kind of language? And what it would mean if a nice girl should come along - his own sort of a nice girl — ready to let him spill his own troubles out to her - in his own sort of jargon?"

I felt, myself, what it would mean. I had heard before of what the Red Cross Bureau of Hospital Administration was accomplishing under the technical designation of the Service of Professional Aid to the Service de Santé - this last the medical division of the French Army establishments. The first opportunity for this service came when General Pershing told Marshal Foch that the American Army was there to be used as the French high commander in chief saw fit to use it. Whereupon Foch moved quickly and brigaded our men with his between Montdidier and Soissons, which meant, of course, the evacuating of the casualties through the French hospitals. The helpless condition of our American boys who did not speak French and very few of them did - can therefore easily be imagined. They could not tell their wishes nor be advised as to what was going to be done with them. It was then that Burlingame sensed the situation in its fullness; that, with much diplomacy, he first approached Dr. Vernet Kléber, the commander of the French-American section of the French Service de Santé, saying that he realized that its service had been taxed to the uttermost and proffering the 
use of American Red Cross personnel. And Dr. Kléber accepted.

The thirty or forty nurses did not come at one time. But within twenty-four hours, four of them - two nurses and two nurses' aids, and all of them speaking French were dispatched to the French hospital at Soissons where the first American patients were being received. The movement of the First and Second Divisions in the Beauvais and Montdidier sectors right after increased very greatly this flow of Yankee doughboys into French hospitals - and the American nurses were thrown into them in far greater numbers. Soon a still more definite plan was adopted, which resulted in American nurses, speaking French, being installed in each and every French military hospital which received American wounded. Under this arrangement our nurses were given French military papers for free travel - at the very outset, one of the many timesaving arrangements in a situation which all too frequently was a race between time and death. Another time-saving scheme provided for the reassignment of nurses used by the French Service de Santé without the necessity of approval in advance by Paris headquarters. This very flexible and sensible plan relieved the situation of much red tape and made for immediate results. And not the least of its advantages was the fact that it actually did much to enhance the entente cordiale of the fighting forces of the two allied nations.

The first call for nurses under this new arrangement came in May, 1918, when a nurse and an aid were sent to the French Military Hospital at Besançon. in the extreme east of France and south of the fighting zones. The second came from La Rochelle, down on the Atlantic coast. After that the calls were almost continuous, until our American nurses had been sent to all corners of France; the service covering thirty-one departments and eighty-eight cities.

Sometimes, when the calls were particularly urgent and 
the distances not so great, the nurses were sent in camionettes, for time always was an important factor. But more often the nurse and her aid rode by rail, armed with the military permits that were so necessary a feature of travel in France during the days of the actual conflict. One of these girls wrote quite graphically of one of these journeys.

"It was quite dark; there wasn't a light in the car or in the countryside," she said. "Off on the horizon we could see the guns flashing. A very nervous man sat opposite me, pulled out his flashlight about every five minutes, consulted his time-table and announced the next station. Finally he alighted and the only way that we knew when we had reached our station was because heads appeared at every window when we stopped, asking the name of the stopping place. After the information was given the passengers would pile out for that particular place and step into the inky darkness. After which they might resign themselves to spending the rest of the night curled up on one of the uninviting small benches in the station."

The diet of the average doughboy and the average poitu - sick or well - was almost always different. To accomplish this each Red Cross nurse, upon being sent to her assignment, was given small sums of money to spend for the comfort of her patients. In this way she was often able to obtain such things as milk, eggs, or a chop for a Yankee boy who wearied of the diet constantly given to the poilu.

These nurses, like those which were held by the Red Cross in reserve for the emergency needs of our army in France, were in direct charge of the Nurses' Bureau of Colonel Burlingame's department. Incidentally, this bureau furnished some ten thousand nurses in France, of whom eight thousand were army reserves.

The great need of this service in the French hospitals was shown in the extensions of the plan. In several instances where a United States Army hospital unit was stationed 
near a French one, the American patients were gradually evacuated to it, our Red Cross nurses being retained on duty as long as was necessary. There were, of course, many of these American hospitals - some of which you shall come to see before you are finished with the pages of this book. In all of these our Red Cross functioned, both in the furnishing of many of their supplies as well as in the giving of entertainment to their patients. Of all these things, more in good time. Consider now, if you please, the distinctive Red Cross hospitals themselves - some of which long preceded in France the coming of the larger regulation hospitals of the United Sates Army.

The first of these great institutions of our own Red Cross to be secured over there - it bore the distinctive serial title of Number One - was located in the Neuilly suburban district of Paris. It was a handsome modern structure of brick - a building which had been erected for use as a boarding school or college. It was barely completed at the time of the first outbreak of the Great War, and so was easily secured by a group of patriotic Americans in Paris and,- then designated as the American Ambulance Hospital, - placed at the service of the French, who then were in grievous need of such assistance. When we came into the war, this hospital, which contained between five and six hundred beds, was put under the United States Army and the American Red Cross and turned over to the Red Cross for actual operation.

American Red Cross Hospital Number Two - a private institution of the highest class - was formerly well known to the American colony in Paris as Dr. Blake's. Like the Number One, it was one of the chief means by which the Stars and Stripes was kept flying in Europe throughout the early years of the war. It not only contained three hundred beds, but a huge Red Cross research laboratory, where a corps of bacteriologists was quickly put to work under the general control of the Surgeon General's office of the army 
and making valuable investigations, records, and summaries for the American medical profession for many years to come.

Number Three, on the left bank of the Seine, was for a time known as the Reid Hospital. It was at one time a home or dormitory for girl art students in Paris. Later it was transformed into a hospital by Mrs. Whitelaw Reid of New York, who gave it, furnished and equipped, to the American Red Cross and arranged to pay practically all its running expenses. It was a comparatively small establishment of eighty beds, which were reserved almost entirely for officers, and personnel of our Red Cross.

From this most modest nucleus there was both steady and rapid growth until, at the time of the signing of the armistice, there were not three but eight of the American Red Cross Military Hospitals : the three of which you have just read; Number One in Neuilly; Number Two (Dr. Blake's) in Rue Piccini ; Number Three (the Reid Hospital) in the Rue de Chevreuse; Number Five, the tent institution which sprang up on the famous Bois de Boulogne race course at Auteuil; Number Six at Bellevue; Number Seven at Juilly; Number Eight at Malabry (these last three in the suburbs of Paris), and Number Nine in the Boulevard des Batignoles, within the limits of the city itself.

The so-called American Red Cross hospitals were generally somewhat smaller. They were Number 100 at Beaucaillou, St. Julien in the Gironde, Number 101 at Neuilly, Number 102 at Neufchâteau, Number 103 also at Neuilly, Number 104 at Beauvais, with an annex at Chantilly, Number 105 at Juilly, Number 109 at Evreux, and Number 113, the Czecho-Slovak Hospital, at Cognac. In addition to these there was a further group of smaller hospitals, which were operated in the same way as the American Red Cross military hospitals. These included Number 107 at Jouysur-Morin, Number 110 at Villers-Daucourt, Number 111 
at Château-Thierry, Number 112 in the Rue Boileau, Paris, Evacuation Hospital Number 114 at Fleury-sur-Aire in the Vosges, Base Hospital Number 41 at St. Denis, and Base Hospital No. 82 at Toul. While outside of all of these lists were three small institutions in Paris, operated in coöperation with the French, but far too unimportart to be listed here.

There were twenty-six of these American Red Cross hospitals of one form or another established in France through the war. Yet, impressive as this list might seem to be at a first glance, it, of course, falls far short of the great total of the regular base and evacuation hospitals set up by the Medical Corps of our army throughout France and the occupied districts of Germany. Yet even these, as we shall see presently, were constantly dependent upon the functioning of our Red Cross. And, after all, it was chiefly a question of the mere form of organization.

"Form?" said Colonel Burlingame to me that same evening as we sat together in Paris. "What do you mean by form? There is no such thing - not in war, at any event. When they used to come to me with their red tape tangles I would bring them up with a quick turn, saying: 'See here, the Red Cross is not engaged in winning the war for the Allies, or even for the good old U. S. A. We are here to help the United States win the war.'"

Not such a fine distinction as it might first seem to be.

"That was our principle and we stuck by it," continued Burlingame. "And any one who deviated from it got bumped, and bumped hard."

You could trust the young military surgeon for that, just as his own superior officers could trust him to produce results, time and time again. For instance there was that week in July when the news came to him - through an entirely unofficial but highly authentic channel - that the First and Second Divisions of the United States Army were going to be used somewhere near Château-Thierry as shock troops against the continued German drive. For 
weeks past he had been carefully watching the big war map of France that hung upon the wall of his office, indicating upon it with tiny pin flags the steady oncoming of the enemy. And in all those weeks he had been making pretty steady and definite plans against the hour when he would be called upon to act, and to act quickly.

Already he had formed that habit of quick action. Once, it was the seventeenth of June, I think, he had had good opportunity to use it. The First and Second were already in action along the Marne, brigaded with the French, and Burlingame was driving along the rear of their positions. But he supposed that the Divisions were in reserve; he did not realize that it was in actual fighting, not at least until he espied a dust-covered and wounded American quartermaster sergeant staggering down the road. The Red Cross man stopped his car and put the wounded man into it.

"What are you doing here?" he demanded.

"I got hit - with a machine gun," stated the sergeant. "That is, I was with the machine gun. I'd never seen one of the $\mathrm{d} \longrightarrow \mathrm{d}$ things before, but we were fighting. I got a squad around me and we tackled it. We were making the old bus hum when - well, they tickled me with a lot of shrapnel."

Burlingame waited for no further explanations. He headed his car around and at top speed raced back to Paris. As he rode he studied a pocket map that he always had with him. Montmirial! That was the place he had set out in his mental plans for this sort of emergency; in just this sort of an emergency.

The stop at Paris was short; just long enough to load some fifteen tons of hospital supplies in the swiftest trucks Major Osborne's Transportation Department could supply, to pick up the highly capable Miss Julia Stimson - then chief nurse of the American Red Cross - then off to the front once again. Beyond the fact that the emergency 
hospital would be somewhere in the neighborhood of Montmirial, the destination of the swift-moving caravan was quite uncertain. Burlingame and Miss Stimson were both route makers and pace makers. They led the way right up behind the front-line positions, to the chief surgeon of that portion of the French Army with which the First Division was then brigaded. An American colonel was talking to a Frenchman at the moment

"We're here," reported Burlingame.

"Who's we?" asked the Yankee officer.

"The emergency hospital of the American Red Cross," was the instant reply.

The French staff located the outfit immediately, in an ancient château at Jouy-sur-Morin near by, which immediately became A. R. C. Military Hospital Number $107-$ and in a single memorable day evacuated some 1,400 American wounded.

It took real work and lots of it to set up such a hospital as this; also an appreciable amount of actual equipment. First there came the tents and the cots - the most important parts of a mobile evacuation hospital - afterward, in orderly but quick sequence, the portable operating room, with four tables designed for the simultaneous work of four operating teams; each consisting of a chief surgeon, an assistant, two orderlies, and two women nurses. The tables were, of course, but the beginning of the operatingroom equipment alone. There had to be huge quantities of instruments, anæsthetizing tools; and the like.

"Not merely half a dozen forceps," says Burlingame, "but dozens upon dozens of them."

"How could you get them all together?" I asked him.

"It was easy. We figured it all out - when we still had less than fifty thousand American soldiers in France. So that when we had a call for an operating-room outfit we did not have to stop and wonder what we should send out for a well-equipped one. All that was done well in 
advance, with the result that in the high-pressure months of May and June, 1918, we began to reap the benefits of all the dirty work and the drudgery of the fall of 1917."

I interrupted myself - purposely. I was talking of that first week in July when the word came that the First and Second Divisions - no longer brigaded with the French, but standing by themselves as integral factors of the United States Army - were going into action at Château-Thierry. The results of that action need no recounting here. They have passed into the pages of American history along with Saratoga and Yorktown and Gettysburg and Appomattox. They are not germane here and now to the telling of this story of our Red Cross in action. It is germane, however, to know that within fifteen minutes of the receipt of the news of the beginning of the ChâteauThierry fight, Burlingame of the American Red Cross was in his swift automobile and on his way there.

Information already had reached him that our troops were to be pushed northward from Château-Thierry and the sectors about Rheims and southeastward from Montdidier. Acting upon this somewhat meager information he headed his machine straight toward Soissons. A wild ride it was, every mile of it; for Burlingame well knew that every moment counted in the crucial battle against the Germans.

From time to time he would meet motor cars or camions or little groups of soldiers who, in response to his signalings, would stop and frankly tell him what they knew about the position or the movement of our army. But all this information was also meager, and much of it was contradictory. Finally, however, at an obscure crossroads he stumbled upon a group of more than ordinary intelligent Yanks who gave him news which seemed so accurate and so vital that he halted his car and pulled out his road maps. He located himself quickly. And it was not a 
long guess that decided him then and there to establish a hospital.

Remember, if you will, that this man Burlingame is exceedingly long on common sense, quick thinking, and quick acting; short, if you please, on that abominable thing known as red tape. Sensing the situation with a keenness that, in the light of after events, was uncanny, he decided that, when the clash came, it would come midway between Soissons and Château-Thierry, a little to the east of the point where he had halted his car. And there it came. "It was bound to be a hard bump," said he, and so it was.

$\mathrm{He}$ at once got in touch with the American Red Cross warehouses at Beauvais and at Paris and ordered medical and surgical and hospital supplies in abundance forwarded to Chantilly - the point where he had so quickly decided he would locate the emergency evacuation hospital. He ordered eight surgeons, sixteen nurses, and twelve enlisted men, who were on duty at A. R. C. Hospital Number 104, at Beauvais, to proceed at once to Chantilly, where they were met by additional Red Cross personnel sent on direct from Paris. He made arrangements with the Ambulance St. Paul, which was then located at Chantilly, to establish the material and men and women being rushed from Paris and from Beauvais as an annex to its formation. Thus, in a mere twelve hours, was established an American hospital along the French lines of communication.

And none too quickly. On the following morning the big fighting set in to the north of Château-Thierry. And within a few hours the American wounded began pouring into the old French château town of Chantilly. In three weeks just 1,364 of our boys had been accommodated in our emergency Red Cross hospital there; after which there was a shifting of positions and of armies with a removal of the victorious Americans to other sectors, and only French were left in the neighborhood. Which, in turn, rendered it quite easy for our Red Cross to turn over the entire equipment to our French allies, who stood in great need of it. 
Château-Thierry was in fact the first really great test of the American Red Cross. It was its first opportunity to perform its chief and most vital service - the succoring of the wounded men of the United States Army. It met that test. As a single example of the many ways in which it met the test consider the request for three thousand blankets, in addition to several thousand pillows, pajamas, dressings, surgical instruments, and medicines that poured in upon the Bureau of Hospital Administration at Paris at four o'clock on the afternoon of the eighteenth of July. Osborne's department was a little short of motor cars at that particular moment; the continued emergency at Château-Thierry, with the multifold demands that it brought upon every function of the Red Cross, had fairly exhausted his garages. There might be cars in, in a few hours, said the transportation dispatchers. But Burlingame's men took no such chances. They poured down from out of the Regina headquarters and, taking their places in the middle of the Rue de Rivoli, halted and commandeered taxicabs as they hove in sight.

With a half dozen of the Parisian "one lungers" screeching their very souls out in the second speeds, they visited four of the Paris warehouses in quick succession. A truck was brought up out of the offing. By eight o'clock it was loaded, and by midnight it was at the firing line and being unloaded of its precious supplies.

On another night during the same battle, a veteran army surgeon major arrived in Paris at one o'clock in the morning. He found the medical offices of the Red Cross open - there were no hours in those strenuous days when one found them closed - and demanded supplies. The man was faint from lack of sleep. He was put in bed for 120 minutes - not one minute less, not one minute more. When he was awakened, his supplies were at the door. They had been gathered in a motor truck from three warehouses immediately roundabout. 
Later this army man returned to Paris and reported that the work of our Red Cross that night had made it possible for every man in his Division to have a chance for recovery. Hiad it not been for the supplies, he added, sixty per cent of them might have died.

But it was in the quick establishment of hospitals that I think that Burlingame's function of the Red Cross attained its most satisfactory as well as its most dramatic results. Take Number 110 at Coincy, also no great distance from Château-Thierry. It, too, sprang up as a direct result of that famous battle. A radical change of location of our troops in that territory and increasing activities in the neighborhood of Fère-en-Tardenois made an American evacuation hospital at or near that point an immediate necessity. Burlingame, in the same trusty motor which carried him so many miles over the battle-scarred and shell-holed and traffic-worn highroads of France, went out with Colonel Stark, of the Regular Army force, to find a site for it. They decided on a little town of Coincy, on the direct main line of evacuation from the American sector.

The only things that stood in favor of Coincy were its location and the fact that it had water. There was little else left there; not a château or a ruined church or even a barn in which to locate, temporarily at least, a hospital. Moreover, there was no time for picking or choosing in that country through which the boche in the beginnings of his final retreat had just passed. In the center of some partly demolished buildings, Stark and Burlingame found a pump, still in working order. This, they decided, would make a splendid site for their new hospital. The road which ran close by the ruins was the main road to the front - not far away, as the constant booming of artillery attested - and the fact that the railroad also was fairly near simplified the problem of evacuations. These two factors, 
together with that of the water, which was both pure and abundant - the French already had marked the pump, "Eau potable" - decided the question.

So the two men staked a claim to the ruin. Before they returned to the car Burlingame picked up a piece of board. He fished a bit of charred wood out of the débris. It served as chalk. With it he began slowly marking the board: "A. R. C. Hospital No. —." He hesitated for just a moment. What the deuce was the number of that last hospital? Well, no matter. Number 110 would do. And Number 110 it became and so remained even after the hospital was ancient - whole weeks ancient - and finally had been moved to Villers-Daucourt.

"And so with a little burned wood, a piece of busted wall, and a cow yard, the most advanced American hospital in the battle of the Vesle started in," says Burlingame. "We took our burned-wood sign, fastened over the pump - and, voilà, there was Red Cross Hospital Number 110. And then we hustled to the first military telephone and began phoning Paris and other Red Cross headquarters to hustle the stuff out to it. 'Send it up the road from Fère-en-Tardenois,' I told them, ' until you come to the cow yard with the sign. Only look out you don't miss the sign.' . . . And all the time it was raining like hell."

One other of these Red Cross hospitals deserves especial mention in the pages of this book - the tented institution upon the race course at Auteuil just outside the fortifications of Paris. This institution, situated within the confines of the lovely Bois-de-Boulogne, also was established to meet the hospital necessities arising at the crux of the German drive of 1918. It was first planned to take cases far advanced toward recovery and so to relieve the badly overcrowded Red Cross hospitals at Neuilly and other points in the metropolitan district of Paris. And because of this type of cases, and the fact that summer 
was close at hand, it was felt that tent structures properly builded and floored could be used, and so much time saved.

That at least was the plan in May when the race course was commandeered through the French authorities and work begun. In twenty-one days the hospital was completed with six hundred beds, while draughtsmen were preparing to increase its capacity to twenty-four hundred beds.

But as the boche came closer and closer to Paris, that original plan was quickly swept aside, and even the Red Cross made quick plans to transfer its general headquarters to Tours or some other city well to the south of France. Auteuil became, not a convalescent resort, but a military emergency hospital of the first class - American Red Cross Hospital Number Five, if you please. It soon reached great proportions. In the five months that marked its career - from May 30 until the end of October, 1918 - it received 8,315 patients who had a total of 183,733 days of hospital treatment and 2,101 operations. Nearly five per cent of all the surgical cases of our army in France passed through its portals. And when under the sudden and almost unexpected pressure that was placed upon it, it found itself seriously short of personnel - the men and women already working it fatigued almost to the point of exhaustion - nurses and other workers were drawn from the Children's Bureau, the Tuberculosis Bureau, and other functions of the American Red Cross. They were not registered nurses, to be sure, with neat little engraved diplomas in their trunks, but they were both willing and efficient. And that, at that time, was all that was necessary. I think that I have already referred to our Red Cross in France as a mobile institution.

When the Auteuil plan was first brought to the attention of the officers of the Medical Corps of our army they were inclined to scoff at it. To them it seemed vast, visionary, impracticable. And as Burlingame went steadily ahead with his plan - in those days, remember, it 
was to be chiefly a rest camp - there were folk even in the ranks of the Red Cross who criticized it. Then it was that Burlingame answered criticism, not by drawing in on his plans, but by greatly extending them, by planning to build a full surgical evacuation hospital out there on the race course in the park. The criticisms grew, and finally Perkins, whom you already know as the head of the Red Cross organization in France, called the young doctor to him.

"They say that we already have two excellent Red Cross surgical hospitals here in Paris and that they are quite enough," suggested Perkins.

"We shall need more," insisted the hospital expert of his organization.

"The medical sharps in the army don't think that it is necessary," added the Commissioner.

"Then they are wrong," said Burlingame. "We are going to need Auteuil - and we are going to need it mighty badly."

"Then go to it, Major," said Perkins.'

And Burlingame went to it, with the results that we have just seen, while those very army men who eame to scoff at Auteuil remained to praise it - in unmeasured terms.

"It was a godsend," said Colonel Samuel Wadhams, medical officer on General Pershing's staff. “I don't know what we would have done without it."

Done without it? I sometimes wonder what the American Army really would have done without the hospitals of the American Red Cross. Although far fewer in numner than its own, they performed a valorous service indeed. In the six great eventful months from the first of June to the first of December, 1918, these Red Cross hospitals together furnished an excess of 1,110,000 days of hospital care to our troops, which was approximately the same as giving to every battle casualty in the A. E. F. five days of care. It admitted to its hospitals a total of 89,539 sick 
and wounded men, and cared for them - not merely adequately, but with a real degree of comfort - at a total cost of 9.57 francs (a fraction less than two dollars) a day.

Back of, and closely allied to, these distinctive Red Cross hospitals were several groups of auxiliary institutions, which also had been financed and equipped and were under the care of our American Red Cross. The first of these groups was that of the military dispensaries, the value of whose work can be roughly estimated by the fact that Number Two, down at Brest, cared for 1,751 cases in the first month of its existence. The others of the socalled permanent dispensaries were at Bordeaux, Lorient, Nantes, Neuilly, Paris, and St. Nazaire, while temporary ones were operated from time to time and as the emergency demanded at Dijon, Senlis, Verberie, Compiègne, and La Rochelle.

Nine American Red Cross infirmaries were operated at base ports and along the lines of communication for our doughboys. These served - and served efficiently men taken ill on trains, or casuals passing through. During October, 1918, one of them treated 659 cases, while another in three weeks had 850 cases, while with the increase of deportation of our sick and wounded the work of our Red Cross infirmaries was greatly increased. In November, 567 - cases passed through the one at Brest and in the following month 6,549 cases through the Bordeaux infirmary. In addition to these two most important base ports, infirmaries were also operated at Dijon, Bourges, Angers, Nantes, Tours, Limoges and St. Nazaire.

A still more interesting line of Red Cross work closely allied to its hospitals was in the convalescent homes which it established at various places in France, almost invariably at points which had especial charm of scenery or climate to recommend them. There were eleven of these; at St. Julien, at Biarritz, at Morgat, at St. Cloud, at Vetau, at Le Croisic, at Rochefort-en-Terre, at Villegenic-le-Buis- 
son, at Hisseau-sur-Cosson, at Avignac, and at Antibes. In some cases, these were established in resort hotels, temporarily commandeered for the purpose and in others in some of the loveliest of the châteaux of France. It so happened, however, that our convalescent home at Antibes, at the very point where the Alps come down to meet the sea, was in a hostelry - the Hôtel du Cap d'Antibes, Through the courtesy of a young Red Cross woman who was housed there for a time as a patient I am able to present a picture of the life there - a picture which seems to have been fairly typical of all those immensely valuable homes.

"It is a quiet place," she writes, "truly peace after war - and there the tired nurses and workers find the rest they need. Those who want to be really gay must go to Nice, Cannes, or Monte Carlo. In the morning nearly every one goes out on the rocks with a rug and a book for a sun bath. But if you had as fascinating a perch as my favorite one it would have to be an absorbing tale that could hold your attention. For, from the warm waveworn rock that made a comfortable seat, I could look out across a broad sweep of blue water to a ragged range of dark-blue mountains against the paler blue sky. To the left is a little point of rocks where some one had built a villa in the shape of a Moslem mosque, which raised crescent-tipped domes and towers from among a grove of dark-green firs and gray-green cactus. To the right, where the mountain peninsula joins the mainland, the coast sweeps toward me in long, tawny curves. Villas make tiny dots among the green of the hills and along the shore, while at a distance, but I know that near by one finds in them a variety of shades of cream and buff, yellow and pink, and above the last bit of coast to the extreme right rise snow-capped Alps.

"If one is restless there are rocks to climb and fascinating paths to explore. One leads over the rocks, around 
a wall, and up through a jungle-like tangle of neglected gardens and walks into the estate belonging to the King of the Belgians. The villa, begun before the war, is unfinished now, but a truly adventurous spirit will go on past it and be well rewarded. In what was once a formal garden, hyacinths and many colored anemones are blooming in the long grass ; roses nod gayly from the walls, and almond blossoms lift their delicate pink flowers against that glorious sky. In a grove of olive trees near by, narcissus and daffodils are scattered in thick clumps here and there. There is a fragrance in the air that is like spring at home.

"Noon at Cap d'Antibes brings every one together for lunch and after that some go back to the rocks, others to their rooms, and still more take the afternoon bus to Cannes. You can shop there and get your films developed and your hair washed, but of course there are far greater attractions. From three until four an American band plays in the pavilion and all the world walks down the promenade to hear - 'Smiles,' ' The Long, Long Trail,' and 'Over There.' Just such a band played just such tunes last summer at lunch time on the White H'ouse lot in Washington - only there the audience was composed of hundreds and hundreds of women and girls - war workers - with a few men in uniform, while at Cannes it is the other way about. The place simply swarms with American boys on leave or convalescence, officers and men, and besides their familiar khaki there is plenty of horizon blue and the mustard-colored coats of Moroccans, with red fezzes atop. There are French women, of course, and then a handful of Red Cross and ' $Y$ ' girls, nurses, and foreign sisters.

"There are a variety of places to go for tea - from the conventional, cosmopolitan rooms of the Carlton or Rumplemeyer's to the ' $\mathrm{Y}$ ' canteen where one can get good hot chocolate and bread and jam for forty-five centimes. This ' $\mathrm{Y}$ ' by the way, is considered their star establishment. There are reading and billiard rooms, movies and dancing; 
and on Sundays, services are held where one used to play roulette.

"There is also a Y. M. C. A. club for officers, and here there is dancing to be had as well as tea. But at five o'clock the girls for the Cap must run, or they will miss the bus going back No one wants to do that, and miss, too, the pleasant ride along the coast with the sunset glowing back of the Esperal Mountains and shimmering in a thousand colors across the ripples of the quiet sea; especially when the alternative to missing the bus is an hour's ride on a French 'tram.' So, singing as a rule, the busload swings along the smooth white road with twenty-five or thirty girls, as like as not, in the places where fifteen are supposed to be.

"That same big bus is used several times a week to take parties for the long ride along the Riviera, to Nice, Monte Carlo, and Menton - one of the supremely beautiful drives of the world. There is an hour's stop in Nice, another in Monte Carlo for lunch, and then, after a glimpse of the Italian border, the party turns back. The Hotel Cap d'Antibes, with its many lights, looks very pleasant after the long, cold ride - it is always cold on the Riviera after the sun goes down - and dinner, always good, tastes especially so to the hungry tourists.

"The Cap is too isolated to be gay in the evening; but, after all, most of the women there have come to rest and recuperate, so they are glad of a quiet game of bridge, a book before the open fire, or a short walk in the magic of southern moonlight. The energetic younger ones usually pull back the rugs and dance - a hen party, to be sure; fun just the same, if one judges by the faces of the girls. There is generally singing, too. One nurse while I was there had a very lovely voice (you kept thinking how much pleasure she must have been able to give the men in her ward) and after she had sung the verse of some popular song, evcry one joined the chorus. And it was at one of these singsongs, in the big white-paneled drawing-room, 
with the yellow light falling on many faces about the piano, that I had a glimpse of a gray hospital ward and one of those tragic commonplaces that make up the life of a nurse in times of war.

"The singer had been singing a favorite song of the British Tommies with a strong cockney accent:

" 'Oi want go 'ome,

Oi want to go 'ome,

Now that Belgium is Belgium again,

Now that France has got Alsace-Lorraine,

Carry me over the sea,

Where the Allymand cannot get me,

Oh my, I'm too young to die,

I want to go 'ome,'

when a girl near me, who had been rather silent, spoke for the first time:

" "That song reminds me of a boy I used to have in my ward. He had a broken back and it was just a question of time, but he didn't know that. He sang that song until I thought I couldn't stand it.'

"The singing was still to be heard as I slipped into my coat a few minutes later and went out of doors. Down on the rocks the water slipped against them softly, overhead were a million stars in the dark sky.

"And so, war - hideous and relentless - intrudes even on the peace of beautiful places, as it always will for most of us as long as we live. But even if the memories of what lay behind them came back to the nurses who had their leave at Cap d'Antibes, the days there were mostly happy ones. Nothing that the Red Cross has done has been more worth while than this place that they have had for the nurses who needed rest and recuperation. There were the creature comforts of hot water, good food, and soft beds; there was sunshine after an eternity of rain; peace after war." 


\section{CHAPTER IX}

THE RED CROSS IN THE HOSPITALS OF THE A. E. F.

A $\mathrm{T}$ no time was it either the object or the ambition A of the American Red Cross to build or equip or operate all the hospitals of the United States Army in France. For a more or less privately organized institution to have taken upon its shoulders, no matter how broad they might be, the entire hospitalization of an army of more than 2,000,000 men would have been suicidal. So our Red Cross in its wisdom did not even make the attempt; it was quite content to build and equip hospitals in the early days before the American Expeditionary Forces had completed their organization and so were themselves unable to work out their hospital problem as they were forced to do at a later time. The Red Cross did more; it conducted hospitals during the entire period of war - as you have just seen - and attempted to make these models, experiment stations, if you please, from which the medical experts of the army might derive inspiration and real assistance. But at no time did it seek to usurp any of the functions of the Surgeon-General's office of the army - on the contrary.

"When the army was ready to tackle the hospital problem in fine theory we should have gotten out," Colonel Burlingame told me; " but we did not. We were following out the first clause of our creed, which was to meet emergency whenever or wherever it arose and no matter at what cost. And at all times during the progress of the war the emergency compelled the Red Cross to at least maintain its hospitals. And so it did, with a total capacity up to the time of the signing of the armistice of some 14,000 beds. After that we dropped off pretty rapidly. Our pay-roll lists of personnel show that. On November 208 
11,1918 , these contained the names of 1,771 men and women; by the first of the following March this total had dropped to a mere 2.70."

So it was that upon the heels of the first established Red Cross hospitals in France there came the huge hospitals of the United States 'Army in great size and profusion. Sometimes these were gathered in groups - as at Savenay or Allerey or Dijon or around about Brest or Bordeaux and at other times they stood alone and at comparatively isolated points. Even these last were sizable institutions, huge even according to the hospital standards of our largest metropolitan cities in America; while, when you came to a point like Savenay - halfway between Nantes and St. Nazaire - you beheld a group of seven individual hospitals which, shortly after Armistice Day, attained a total capacity of 11,000 beds and were planned, in fact, for some 9,000 more, with a further capacity of another 10,000 feasible and remotely planned. Into this great group of institutions there came between August, 1917, and May, 1919, some 85,000 wounded American boys. Its maximum staff consisted of 500 officers, 500 nurses, and a general staff of 4,000 enlisted men.

When I visited the place - at the end of April, 1919it still had some 6,500 patients, the most of whom were well out of danger and were enjoying the warm sunshine of a rarely perfect day in France I found the headquarters staff ensconced in a group of permanent stone buildings which, in the days before the war, were part of a normal school standing alongside the highroad to Nantes. This, itself, formed a hospital for general cases. Some of those that were grouped with it in the open fields around about specialized in serious bed surgical cases, in contagious diseases, in tuberculosis, in mental cases. This last had handled 7,500 cases in the progress of the war.

In each of these hospitals - as in each and every one of the United States Army hospitals in France and the 
occupied areas of Germany - the Red Cross functioned. At Savenay it had not only erected recreation huts for the men of each of the individual hospitals, but a huge auditorium or amusement hall, permanently fabricated of brick and steel and glass, equipped with a complete theater stage, and capable of seating between 1,500 and 2,000 doughboys and their officers. This super-playhouse was in use every night of the week - for cinema, for drama, sung or spoken, for dances, and, from time to time, for meetings and for religious services.

To this entertainment phase of the American Red Cross in the hospitals we shall presently return. For the moment I shall ask you to consider the part it played in the essential job of supplying hospital supplies. It was not, of course, either practicable or possible for our Red Cross to supply all of these - or even any tremendously large part of them. But it could - and did - supply goodly quantities of all of them when they were most needed, and so worth ten times their value and quantity at any other time.

Time and time again it furnished materials, both for their regular and for their emergency necessities. Sometimes the army itself did not function properly - there were instances of red tape disgraceful and some, too, of red tape inevitable. And yet there were other times when all the tape cutters in the world could not have saved the situation, but the American Red Cross, with its emergency warehouses and its well-organized transportation system all the way across the face of France, did save it. A truckload, two, three; perhaps even four or five truckloads of beds or bedding - perhaps even a small camionette filled to the brim with dressings and drugs or surgical instruments could, and did, save precious lives - by the dozens and by the hundreds. Do you remember, in the preceding chapter, the several instances where our Red Cross played its part - and no small part at that - in the winning of 
the big fight at Château-Thierry? Those were not unusual instances; they were fairly typical.

There came one day when the commanding officers of the U. S. A. hospital center at Allerey - one of the largest in all France - sent for Captain James C. Ramage, the American Red Cross representative in the district. He told the Red Cross man that a tremendous convoy of wounded soldiers from the Soissons-Rheims district was expected within a few days and asked his help in securing a real bulk of medical supplies. Those were the days when the Surgeon General's department of the army was not always able to furnish even drugs and dressings when they were most needed.

Ramage lost no time in discussing the thing. He said that he would do his best and caught the first train into Paris; spent several days there in getting together the necessary supplies, personally supervised the loading of them into a freight car, and then performed the unheard-of feat of inducing the French railway authorities to attach the freight car to a fast passenger train bound down to Dijon. Camions were rushed from Allerey to Dijon, and two days later the necessary supplies were all at the hospital center - and well in advance of the coming of the wounded soldiers. On another night in that same summer of 1918, some 2,250 wounded Americans poured into that selfsame army hospital center of Allerey. The hospital warehouses were exhausted. The Red Cross's were not; do you remember what we said at the beginning - that the fullness of its job lay in its being forever ready to meet any emergency which might arise?

It was being ready that made it able that hot August night to turn into the crowded hospital in a space of time to be measured in minutes rather than in hours, 10,000 blankets, 10,000 sheets, 8,000 towels, 8,000 pairs of pajamas, 2,000 yards of Dakin tubing, 1,000 operating gowns, 1,000 helmets, and two whole carloads of surgical dressings.

Emergency work! How it always does count! 
The securing of these supplies in the beginning was, of itself, a master problem. It involved not alone purchase but manufacturing - manufacturing upon a really enormous scale. We saw at the beginnings of the Red Cross work in France the various workrooms in Paris which devoted themselves to the making of dressings of one sort or another and in tremendous quantities. Yet the actual beginnings of this work antedated even the establishment of the Paris workrooms; immediately on the outbreak of the European War, a special department was established at the National Headquarters of the American Red Cross in Washington for giving advice concerning hospital garments and supplies for European relief and furnishing patterns and samples for the same. A New York City committee, organized for the same purpose by Mrs. Mary Hatch Willard, began the sending of old linens to French hospitals. This work grew into a unit known as the Surgical Dressings Committee of the United States, for the making of dressings by volunteers in this country, and finally led to the establishment of the first of the Paris workrooms. By the time that Pershing had first arrived in France this work in America had grown to a point where it employed more than two thousand committees and subcommittees. Its output increased so rapidly that in the week ending August 27, 1917, ninety-two hospitals were supplied and 155,261 dressings were made in the Paris workroom alone. And that, of course, was long before there were any American wounded. In the summer of 1917 the National Surgical Dressings Committee entered into cooperation with the American Red Cross and from that date its efficient distribution service in France became the Surgical Dressings Service Department of the American Red Cross.

Then came the imminent necessity of standardizing these surgical dressings - which was accomplished by a special board which Pershing appointed at the end of August, 1917. Its standards were followed, but its energies only 
dimmed at the time when it was actually seen that they were quite exceeding the necessities of the situation. And the volume of those selfsame energies is perhaps the better understood when it is realized that from October, 1917, to January 22, 1919, 147,230,777 cases of surgical dressings alone, both donated and manufactured, were received at the Red Cross warehouses in Paris.

Splints, of which an immense number were necessary even for the very short period in which we were actually engaged in the conduct of the war, formed a real Red Cross specialty. Our army hospitals were entirely dependent upon the American Red Cross for these necessities - the total orders for which in July and August of 1918, totaled some 15,000 to 20,000 weekly. For that entire year the output was 94,583 splints, the factories often working from eighteen to twenty hours a day to keep pace with the requisitions upon them. Our Red Cross also supplied all the nitrous oxide used in American hospitals of every type in France. The use of this ultra-modern anæsthetic, to the increasing exclusion of ether and of chloroform, forms one of the fascinating chapters of the medical conduct of the war. Although it had been employed as an anæsthetic in the United States for a number of years before the beginning of the war, its first use in Europe was when Colonel George W. Crile - the distinguished surgeon from Cleveland, Ohio - introduced it into operations in the then American Ambulance Hospital at Neuilly - afterward the American Red Cross Military Hospital Number One. That was in 1915. Nitrous oxide as an anæsthetic immediately attracted the attention of a number of eminent British surgeons.

"It is good," said Colonel Crile, tersely.

And so it is - good. It is so good that Colonel Alexander Lambert, at that time chief surgeon of our American Red Cross, immediately made it the standard anæsthetic of its medical service. For, like so many other American surgeons, he quickly concurred in the opinion that nitrous 
acid, used in combination with oxygen, three parts to one, is the least dangerous as well as the best adapted for use when operating upon cases of chest surgery, abdomen wounds, or of shock. Under this anxsthetic the percentage of recovery is seventy-two per cent, as compared with fifty per cent for either chloroform or ether. Moreover, it has none of the disagreeable after effects which come almost invariably with the use of chloroform or ether. To quote Colonel Lambert:

"The use of nitrous-oxide anæsthetic to the exclusion of ether or chloroform in case of at least the seriously wounded seems to me not only advisable but beyond the advisability of discussion."

Its official use, therefore, was predicated. It was first supplied to the casualty-clearing stations; American and British coöperating for the sake of an exchange of ideas as to its best use. Our Red Cross supplied an apparatus of special design that had gradually been evolved from those already devised. This allowed the separate administration of the nitrous oxide, of oxygen, or of ether - which at times was used in small quantities - or of the three in various combinations. And all our American nurses were trained as anæsthetists in its use.

The making of the nitrous-oxide gas itself was one of many similar tasks assigned to the Manufacturing Department of our Red Cross, of which Major Arthur W. Kelly was department chief. He ordered a huge gasmaking plant from America which, after some considerable delay, finally was set up at Montreau, fifty miles distant from Paris. In the meantime the Red Cross had discovered a man in the French Army who had had some experience in the making of nitrous oxide. He was released from active army service and at once started to work making an emergency supply, the limited quantities carried to France by Colonel Crile having become completely exhausted. This small plant had a daily capacity 
of about 4,000 gallons. But when the bigger machinery from America had finally been set up - in the midsummer of 1918 - this output was increased to 75,000 gallons a day. This could easily have been doubled, had it not been for a single limiting factor - the extreme difficulty of securing 3,280 gallon cans in which the gas was transported. Finally the Red Cross secured some hydrogen tanks that had been captured from the Germans in their first July defeats. It was then and not until then that the nitrous-oxide plant began running at anything like its real capacity. And with the definite result that from September, 1917, to October 23, 1918, our Red Cross was able to supply our army with 699,420 gallons of this precious anæsthetic, its own hospitals with 405,620 gallons, and some miscellaneous institutions with an additional 251,110 gallons, while it saw Great Britain formally acknowledge nitrous oxide as an anæsthetic par excellence and even conservative France making the first steps toward its adoption.

A few of the medical and surgical requisitions of a typical American Army Division - the Second - upon our Red Cross are before me as I write. They are indicative of the overwhelming demands that were made upon it, not only from every corner of the front, but from every corner of France that was occupied by our fighting men and what corner was not?

It was at the request of the chief surgeon of this Division that one of its field hospitals - originally supplied direct from the army's own sources of supply - was amplified by the American Red Cross, by the use of Bessoneau tents and other equipment so as to become practically a mobile unit, capable of handling far heavier cases. The supplying of the equipment shown by these requisitions began while the division was still in the vicinity of Montdidier and continued until after it had moved to Meaux and was in active preparation for its great rôle at Château-Thierry. 
In addition to the Bessoneau tents, the following were the requisitions which were delivered to this single formation while it was under heavy pressure:

June 1: 1 tortoise tent and 100 collapsible cots.

June 3: 12 antitoxin syringes for anti-tetanus serum, 200 packages of absorbent cotton, 30 feet of glass tubing, and 25 operating gowns and caps.

June 4: 250 single blankets, 100 litters, 5,000 anti-tetanus serum, 2 autoclaves, 4 thermometers for autoclaves, 50 wash cloths, 1,000 pairs of socks, 50 towels, and 200 comfort kits.

June 6: 50 clinical thermometers, 2,000 temperature charts, 1 gallon of green soap, 36 bottles of ammonia, 5,000 Greeley units, 20 syringes, 15 liters of Lysol, 20 chart holders, 100 rubber sheets, 2 small instrument sterilizers, 500 nightshirts, 500 blankets, 1,000 sheets, 500 forks and spoons, 100 bedside tables, 100 folding chairs, 50 hot-water bottles, 36 maps, 50 hand basins, 20 bolts of gauze, 10 bolts of muslin, 100 beds, and 100 mattresses.

June 7: 200 litters, 250 blankets, 100 rolls of cotton, 200 rolls of gauze, 144 rubber gloves, 100 operating gowns and caps, 96 tubes of catgut, 500 Carrel pads, 100 gowns for nurses, 20 sterile water containers, 5,000 folded gauze compresses, and 5,000 small sponges.

I rather feel that this record of a single week of the demands of one Division upon our Red Cross will show quite enough the burden which it was forced to bear; and bore most joyously as a part of the opportunity for service which was given unto it in France. In a single day and night during that same great offensive of 1918, 128 different requisitions - each comprising from one to fifty items - were started out on the road from Paris; while on the twentieth of August of that same summer - the day which marked the beginning of the St. Mihiel drive 120,000 front-line emergency parcels and more than fifteen carloads of surgical dressings were shipped to the scene of activity. From the Paris headquarters of the Red Cross alone, supplies were shipped that summer to sixty-six base hospitals, two naval-base hospitals, fifty-four camp 
hospitals, twenty-one convalescent hospitals, twenty army divisions, seven evacuation hospitals, nine field hospitals, eight hospital centers, nine mobile hospitals, six medical supply depots, and the central medical department laboratory - all of the United States Army in France. This great record does not, of course, include the supplies sent to the Red Cross's own hospitals or those sent to the A. E. F. hospitals from the nine zone headquarters of the American Red Cross; nor even emergency supplies sent to eighteen detached American Army units, far away from their bases of supplies. In a single month and from one warehouse, our Red Cross made the following shipments to formations operated entirely by our army: 77,101 surgical instruments, 2,820 beds and cots, 24,733,126 surgical dressings, and 15,300 pounds of drugs.

It also supplied specialties, and all for the comfort of our wounded boys over there. Take ice - that simple product of our modern civilization - so indispensable to the American. It is second nature with us to-day and yet little used by the French. Ice is as much an essential to our up-to-date hospitals as drugs or nurses or the beds themselves. Properly packed, it cools the fever and so greatly eases the sufferings of wounded men as they toss upon their cots. Its beverage use is too universal to even need comment here.

"My, that's good!" more than one sick boy murmured, as the nurse held a spoonful of it to his hot lips. "It's just like home."

Yet, while our government planned ice-making machinery for each of its hospitals, large or small, they were not always ready as quickly as the rest of the plant. There again our Red Cross stepped into the breach, supplying small portable ice-making plants not only to the field hospitals for which they were originally designed, but even for larger installations. Each of these portable plants consisted of a gasoline engine of fifteen horse power, water-cooled and attached to a compressor, which in turn 
was connected to the water piping in the brine tanks. The capacity of each of these was about two tons and a half each twenty-four hours. And each was accompanied by two Ford camionettes - builded with special ice boxes to carry its product to the wards roundabout.

Second only to ice in importance as a hospital auxiliary was light. In the early years of the war, the surgeons of the allied nations worked under great difficulties at night and undoubtedly many lives were sacrificed because of the lack of proper lighting facilities. I have heard of the doctors ripping off a wounded man's clothing by the light of one star shell and waiting for the next to give them enough brilliancy to examine his injuries.

For at least ten or a dozen years past our larger American circuses have used portable electric-lighting plants on their various itinerant trips across the land - with a fair degree of success. Those circuses gave our Red Cross in France an inspiration. Lieutenant Harry C. Hand, a director in its Central Department of Requirements, in studying the markets for the proper sort of equipment, used them as models and so evolved, as a plant most practical for Red Cross needs, a three-and-a-half kilowatt outfit consisting of a gasoline engine, an electric generator, and a switchboard. This outfit, mounted upon a stout camion, would light 135 incandescent lamps of twenty-five watts each. On its travels it carried in its lockers the lamps, extension cords, sockets, and the like to make them available for almost instant service. And the Red Cross in the heart of the war emergency had five of these outfits at its service in France.

One other allied factor in this hospital supply service deserves attention before we finally turn away from it. I have referred from time to time to the vast quantities of drugs which our Red Cross distributed to both its own and other hospital centers. It was obvious that this distribution had to be centralized, and because of the delicate 
and extremely valuable nature of this particular form of supplies be kept quite separate and distinct from the others. So "The Red Cross Pharmacy," as it was generally called, came into existence, at a former apartment building at No. 10 Rue de Tilsitt, Paris, and quickly came to such importance that it was made the headquarters of the Section of Hospital Supplies, which in turn was a division of the larger Bureau of Hospital Administration.

Throughout all of the hard months of the war this section boasted that each night found the requisitions for that day filled. There were no left-overs; not even when a single day's work meant fifty-six huge orders entirely completed, and little rest for a staff which averaged forty-one men and women.

The pharmacy was well systematized. In its basement were the receiving, the packing, and the shipping departments, while upon its broad main floor the drugs and antiseptics were actually stored, the second floor being given to dental supplies, surgical instruments, rubber goods, sutures, serums, laboratory equipment, and the like. Each of these various departments was in charge of a specialist, a man of many years' experience in the line which he headed.

By June, 1918, the pharmacy in the Rue de Tilsitt had become of such importance that it was re-created into a Section of Supplies, with Major George L. Burroughs, of the Massachusetts College of Pharmacy in Boston, as its sectional chief. Within a month he had found the demands upon his department so much increased that he was forced in turn to increase its facilities - by the addition of two warehouses. In another six weeks a new burden was placed upon his shoulders - the distribution of all alcohol, ether, oxygen, and nitrous acid issued by our Red Cross, which meant, of course, more space needed - so the unused powder magazine at Fort D'Ivry and the riding academy at No. 12 Rue Duphot - both loaned by the French 
Government authorities - were added to the quarters of the pharmacy.

Some idea of the amount of work undertaken and accomplished by this Red Cross pharmacy may be gained when it is understood that in the six months ending January, 1919, 75,016 pounds of drugs were issued from it. There were in that time 3,954,178 tablets, 21,566 phials of serum, 271 surgical units, 15,108 pairs of rubber gloves, and 22,059 feet of adhesive plaster, in addition to many hundreds of packets of other drug supplies.

Seemingly we have drifted away from our American boys, sick or wounded and in hospitals. In reality, of course, we have not Every one of these provisions, large or small, was aimed directly at their comfort, while each deserved to be rated as a necessity rather than comfort comfort, at least, as the average luxury-loving American knows it. It was comfort rather than luxury that I found our boys enjoying there at Savenay - long, comfortable huts, builded hurriedly but furnished with great care, great taste, and great atrractiveness. Savenay, itself, was a good deal of a mud-hole, a fearfully wretched place underfoot. The Red Cross huts shone brilliantly in contrast. Here, as in the canteens all over France, the boys might congregate - practically at all hours - and amuse themselves as their fancies dictated; or, if fancy grew a bit bored, it was part of the job of the directress - one of whose essential qualifications was resourcefulness and another versatility - to find some new form of amusement. It was not enough to hand out the cigarettes - one or two packs a week - or the pipes and the playing cards and the tobacco, pretty much as requested - there had to be shows. The American passion for play-acting is something to be reckoned with.

Perhaps you do not quickly understand how versatile those very shows might readily become. Let me quote from Toot Sweet - the little fortnightly newspaper which 


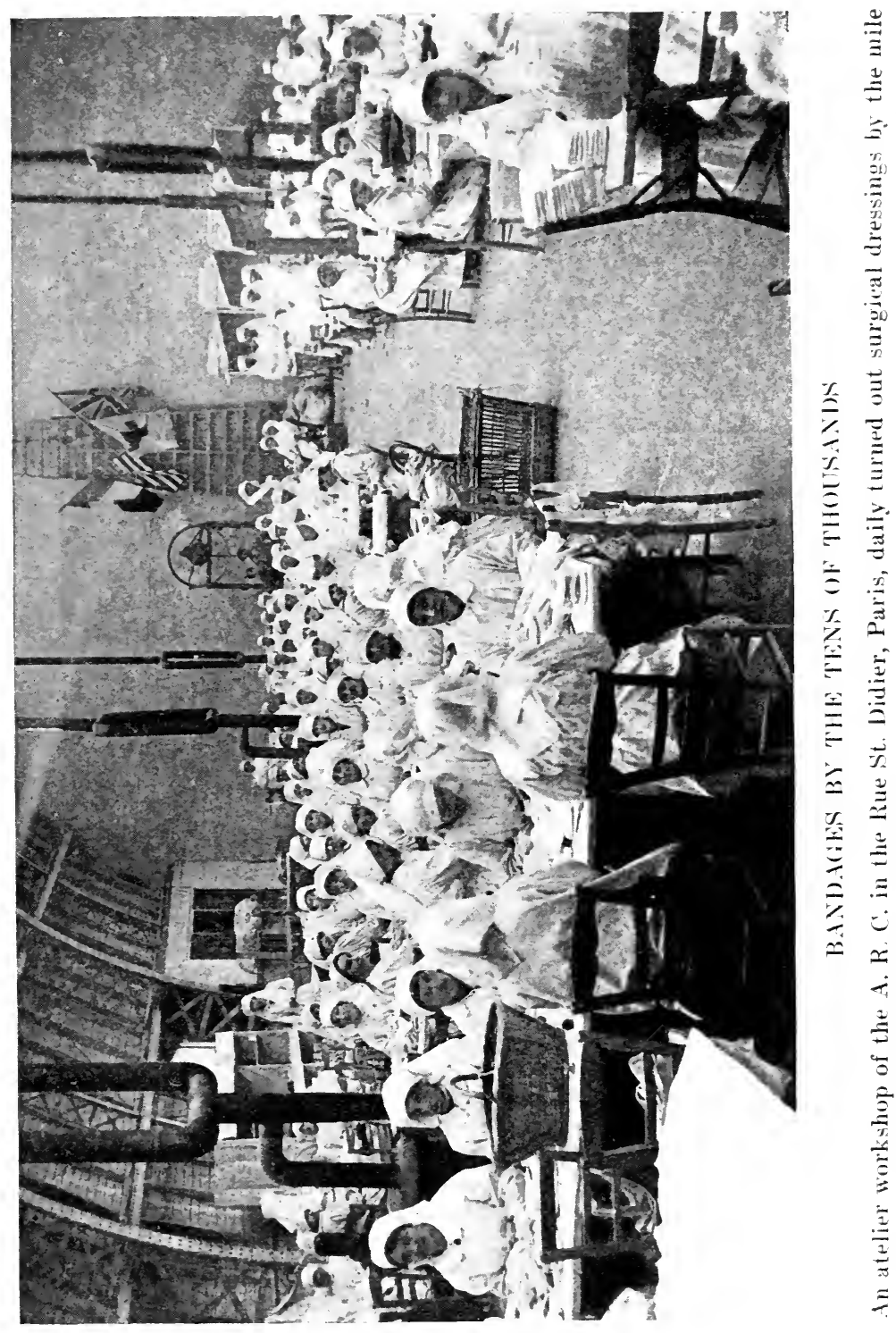



our American Red Cross printed for the boys convalescing there at Savenay. That is, the Red Cross furnished the printing press, the type, and the rest of the paraphernalia for the making of the publication; the boys, themselves, supplied the brains that made it so very readable at all times.

" ' Stunt Night,' advertised in Base 69 Hut for March 13, brought a lot of inquiries," says Toot Sweet, in its issue dated April 1, 1919. "'Whadaye mean - stunts?' Probably the announcement of pies and doughnuts for prizes was responsible for the crowd that appeared that evening when a large part of the floor space was cleared and a couple of Red Cross hut workers started the stunts. The first stunt - with a large slice of apple pie as prizes - was to sit upon a piece of iron pipe, diameter six inches, place the heel of one shoe on the toe of another, and while thus insecurely balanced, light in one hand from a lighted candle in the other a cigarette. Shrieks and howls from the delighted mob who began betting on results encouraged a number of aspirants and the pie was finally won. Stunt after stunt followed in quick succession, all sorts of queer and absurd contortions varying from picking up folded newspaper from the floor with your teeth while holding one foot in the air with one hand to a 'puttee race,' when the contestants raced from one end of the hall, took off their puttees, and then put them on again, then raced back, with various obstacles in the way. Finally the boys began challenging each other to their favorite stunts, so that Private California might have been showing Private North Carolina a pet trick, while Sergeant Oklahoma and Corporal Louisiana gravely discussed the merits of their ideas on stunts. The winning team was presented with a large, juicy apple pie, vamped from the mess sergeant by a Red Cross girl.

" 'Amateur night' was announced for the same hut two nights later by a stunning poster done in colors by one of the 309th Engineers. A box of homemade fudge was 
the prize for the best act. Seven of the best vaudeville acts ever seen in the huts appeared. The sergeant major of Base Hospital Number 69 was the master of ceremonies. A 'dummy' act, a 'wop mechanic' in song and monologue, a ballad singer, a 'song and minstrel man,' a mandolin and guitar player, who gave remarkable imitations of Hawaiian instruments, a 'tramp monologuist,' and a clog dancer composed the bill. Harry Henly, the 'song and minstrel man,' won the box of fudge which was displayed in all its glory and pink ribbons during the contest."

Sometimes there was not quite so much fun in the situation. The girls who ran the Red Cross hut in the tuberculosis hospital of the Savenay group, almost directly across the highroad from Number 69 , had a far weightier problem upon their shoulders. To amuse there, was a vastly more difficult task. For they knew - as most of its patients knew - that the man who entered the portals of that particular hospital was foredoomed. If he had a fighting chance of conquering the "T. B." he was packed into the hospital ward of a transport and rushed home. If he did not have that fighting chance - well, why waste precious transport space? To Savenay with him. And to Savenay he went to spend his days - and end them in a cheery, camplike place where there were croquet and less strenuous games and broad piazzas that looked down across the valley toward the embrochure of the Loire, while Red Cross girls came and went and did their womanly best to comfort and amuse a fellow - and make him forget; forget the back door of the little hospital where, night after night, four or five fellows went out - in pine boxes, never to return, and the rows of wooden crosses down in the American cemetery at the foot of the hill steadily grew.

Turn back with me, if you will, inland from Savenay to the curved streets of Vichy - little Vichy situated in the very foothills of the high Alps. It is January now, not April. We have turned backward in full earnest, and 
are breathing the air of those hard weeks and months that followed immediately upon the signing of the armistice.

Vichy, in its very compactness, with the flat yellows of its curious old buildings and its equally curious modern hotels, with the fifteenth-century tower in the background and the quiet River Allier slipping by, has the fascinating unreality of a stage setting - one of those marvelous effects with which the genius of a Belasco or a Joseph Urban from time to time delights in dazzling us. In spring or in summer we might find it prepared for carnival - with green-painted chairs and tables underneath the still greener foliage of its small park. But this is January and the park is deeply blanketed in snow. In such a serene midwinter setting it seems far more ready for silent drama than for the blare of carnival - the figures in olive drab are indeed quite the figures of pantomime - brown against the whiteness of the snow. The only touches of color in the picture - tiny splotches of green or blue or purple or yellow - are supplied by the tiny cloth bags that the men carry with them. They are preparing to entrain - the first step of many on the way back to the homeland - and the vari-colored bags, each marked with a crimson cross, are the comfort kits they genuinely cherish.

Before war was come upon France, Vichy was a resort to be reckoned with in the comings and goings of her elect. It was a watering place - and much more besides. There men and women ate as well as drank, bands played, beauties intrigued, wheels, flat-set, spun merrily, and entire fortunes were flicked away at the gaming tables; but war changed these things - as many, many others. It took the viciousness out of Vichy and brought back to it all of the gentleness which it must have possessed in the beginning. The small city, where formerly the ill and the bored made pilgrimages in search of health (health bubbling up to the lips in the faint concealments of a glass of sparkling water), became a city of wounded; all too often a city of death. 
The French Army moved in; and, commandeering hotel after hotel, transformed them into its hospitals. On its heels came the American Army; it alone took more than eighty hotels for its own hospital purposes. That was the signal that our Red Cross would be needed, and without further urge it moved in. Wherefore the comfort bags in the hands of the doughboys as they moved across the park toward their waiting trains.

If memories were half as tangible things as war "souvenirs," those tiny bags of the crimson cross would have held other things than soap and razor blades and tooth paste and playing cards and tobacco and the like. They would have held definite memories of Vichy and all that it had meant to the wounded men of our army. Some of them would have carried the pictures of lights shining out through opened doors into the darkness of the night and litters coming in through those opened doors - litters bearing American men, when they were not American boys - men clad only in hospital robes, but whose first bandages were drenched with blood and spattered with the mud of No Man's Land. There would have been a multiplicity of pictures of this sort, for Vichy in the days of actual fighting never was an idle place. There were times there when, within a cycle of twenty-four hours, as many as six thousand men would be sent away from it - to make room for an equal number of incoming freshly wounded soldiers. In the early days of November that many came to it direct from the dressing stations, and the problem of our Red Cross there became a little bit more complex.

There might also have been pictures in those selfsame comfort bags of the Red Cross girls on the stone platforms of the railroad station - young women who in warm days served iced lemonade there and in cold, hot chocolate, or, when it was requested, hot lemonade; for the fact remains that lemonade was the only food or drink that many of the gassed cases could endure. And it was ready for them there - at all hours of the day or night, and at all days; 
even though to make that possible the girl workers would sometimes stay on duty for thirty-six hours at a stretch: without having the opportunity of divesting themselves of their clothing and so gaining a little real rest.

A final picture of Vichy might have well been a mental photograph of the "hut." This formerly had been the Elysée Palace - a gaming and amusement center of none too savory a reputation; yet with its central location on the main street, its ample lounging space, and its small theater, self-contained, it was ideal for the purposes of our Red Cross and so became a living heart of Vichy. It was the canteen or club in which some five thousand doughboys were wont to congregate each day - to write letters home, to play games, or the tireless piano, to read the newspapers or the magazines, to visit, to gossip - in every way possible to shorten days that passed none to quickly for any of them.

During the first months of its organization this Red Cross superhut did not include the entire "Palace." Gradually it spread, however, until the entire two floors of the place were busy with American Red Cross activities. And the doughboy passing from the comfortable clubrooms on the main floor - wherein, for the comfort of the convalescents, a full-fledged army commissary had been set up - upstairs found a "first-aid" room of a new sort. It was, in fact, an operating room, where expert surgery might be applied to torn and ripped and otherwise wounded uniforms. And the head surgeon was a woman - a smart, black-eyed French seamstress who could perform wonders not alone with torn buttonholes but who also possessed a facility with a hot sadiron that made her tremendously popular upon the eve of certain festal occasions.

"How would a dish of Yankee ice cream taste to-day? You know, the same sort that Blink \& Smith serve down there in the Universal, at the corner of Main and First streets?" 
Imagine something like that coming out of the blue, and to a boy who has been "fed up" on army cookery and who even has lost his taste for the delicacy of French cookery. You may take it direct from me that the hut there at Vichy held a kitchen and that it was a good kitchen. Can you imagine any first-rate American club that ever would fail in such an essential? And from that modest cuisine there in the pulsing heart of the bubbly town came truly vast quantities of the trivial foodstuffs that are forever dear to the stomach of the doughboy. Ice cream - of course - and small meat pies, each in its own little coat of oiled paper - and creamy custards and, of course, once again - coffee and all manner of sandwiches, imaginable and unimaginable. And, because there were many of the doughboys who could not possibly make their way to the hut, even on crutches or in wheel chairs, a camionette drove away from its kitchen each day with seventeen gallons of ice cream tucked in it - all for the benefit of bedridden American soldier boys.

Remember, if you will, that this once disreputable Elysée Palace - in the glory of war aid becoming not only reputable but almost sanctified - held a theater; small, but completely equipped. Our Red Cross workers did not lose sight of that when they chose the place as a headquarters for their endeavors. Four days a week this became a moving-picture house - just like the Bijou or the Orpheum back home. On Wednesday French wounded for whom comfort provisions were never too amplewere guests there of the American Red Cross, and each poilu carried away a little gift of American cigarettes to any Frenchman the very greatest of all treasures Saturdays were set aside for " competitive vaudeville" or an " amateur night" - very much as we saw it at Savenay. Gradually a stock company - capable at least of one-act plays - was evolved from the dramatic material immediately at hand - soldiers and Red Cross and hospital men 
and women workers - with the result that by Thanksgiving Day, 1918, a very creditable production entitled "The Battle of Vichy" was produced there in the hut, after which the company moved on toward the conquest of the neighboring "metropolitan" towns of Moulins and ChâtelGuyon.

Some one is going to come along some day and write the analysis of the innate desire of the American to dabble with play-acting. The plethora of war-time musical shows that became epidemic among the divisions of the A. E. F. and spread not merely to Paris - where one of these entertainments followed upon the heels of another - but eventually to New York and other cities of the country, affords interesting possibilities for the psychologist. It was a huge by-product of the war and one not entirely expected.

When the resources of the amateur Thespians of Vichy had become well-nigh exhausted, a New York professional actress - Miss Ida Phinney - who not only had real dramatic ability but considerable experience in staging and producing, was enlisted in the Red Cross service there. With her aid, the attractive little cinema theater - with its blue upholstery, its tiny boxes, and its complete and up-todate stage equipment, even to the scenery - became a fullfledged playhouse. Stage hands and property men were assigned from the army, and Vichy began seriously to stage, costume, and produce and criticize plays. Soldiers with a knack for design took keen delight in advising as to "creations" for the wardrobes of the cast and themselves watched the garments grow into reality from inexpensive stuffs in the sewing room. A clever artist wrought a full set of stage jewelry - even to the heavy bracelets and the inevitable snake rings of the Oriental dancers from stray scraps of shells and other metals that came to his hungry fingers, while the Red Cross sent a full complement of musical instruments down from Paris. And so 
the Vichy A. E. F.-A. R. C. Playhouse came into the fullness of its existence - and night after night hung out the S. R. O. sign.

After all, what is the doughboy's idea of a good time? That is the very question our Red Cross asked itself again and again. And because the correct answer could not be evolved in a moment, established not only after it had arrived in France a Bureau of Recreation and Welfare whose real job was, after plenty of practical experimentation, to establish the correct solution of the problem. For a long time this Bureau consisted of a small desk at the Paris headquarters, a Ford camionette, and Major Harold Ober. The camionette and Ober went from village to village along the lines from Bar-le-Duc to Gondrecourt with books, magazines, tobacco, writing material, and a small moving-picture show. These efforts many times furnished the only amusement to our early troops, billeted in quiet villages, where the quaintness of French pastoral life soon lost its novelty.

From that small beginning, Ober's work grew steadily. And because the Red Cross specialized more and more in that phase of army life which was its original purpose hospitalization - Ober's task became in turn more and more devoted to the hospital centers, large and small - until the time came in practically every hospital ward in France - where the men were not so desperately ill as to make even music an irritant - that the " rag," and "jazz," or the latest musical comedy hit direct from Broadway were constant and welcome visitors to long rows of bedridden boys. In most cases these were phonographs, and because whenever I wish to be really convincing in the pages of this book, I fall back upon figures, permit me to mention that 1,243 phonographs, calling for 300,000 needles and 29,000 records, helped relieve the tedium of the American convalescents in the hospitals of France.

And, while we are still in figures, remember that there were times - unbelievable as it may seem to some folk 
who were frequent visitors to our hospital wards over there - that the doughboy tired of music, canned or fresh, and turned gratefully to the printed page. To anticipate his needs in that regard, American residents in Paris and in London gave generously of their private libraries - a nucleus which soon was greatly increased by purchase. The books were sent around in portable boxes, a service which steadily grew until a library of from 1,000 to 10,000 books was maintained by the American Red Cross in each hospital - a total of some 100,000 all told, and of which a goodly proportion were histories, French grammars, dictionaries and technical works.

The demand for periodical literature was tremendous. In the months of December, 1918, alone, our Red Cross distributed nearly four million magazines and newspapers among our doughboys. Prominent among these last was the Stars and Stripes, the clever and ingenious publication of the enlisted men themselves. A special "gift edition" of this remarkable weekly was obtained from the publishers for distribution in hospitals alone, and this ran into the hundreds of thousands each month - a high limitation which was reached only when the stock of print paper began to run low. The demand upon writing paper was hardly less than that upon print. The doughboy was a regular and prolific correspondent, and before January, 1919, our Red Cross had furnished him with seven million illustrated post cards, seven and a half million envelopes, and fourteen million sheets of writing paper.

But his eternal joy was in "shows." These might be two come-uppish lads, with gloves, going it in a roped arena, a flickering lantern displaying the well-known and untiring antics of Mr. Charles Chaplin or Mr. Douglas Fairbanks, the exquisite artistes of one of the opera houses in Paris in a composition that brought unforgetable joy to the ears and memories of the many, many lovers of music in our khaki - or a homemade production of the doughboy 
himself. Of these the "movie" was, of course, the simplest to handle, and therefore by far the most universal. It began its A. E. F. career in France as a true "barnstormer." As early as July, 1917, a Red Cross man with a French motion-picture operator as an assistant had hied himself out from Paris, riding in one of the universal Ford camionettes, upon which had been mounted a generator and a projector. Upon arriving at an army camp, the show would be "put on" - with little fuss or delay. The smooth, whitewashed side of a stone building would make a bully screen and there was never even doubts of an audience or of its enthusiasms. For from wonderments at this additional strange contraption from the Etats Unis, the peasants and the poilus, who were its very first admirers, grew rapidly into Mary Pickford and Charlie Chaplin and Billie Burke fans. This taste followed closely that allconquering admiration for our chewing gum which overcame the French and left them quite helpless.

Eventually this "movie" institution of the Red Cross overseas grew to sizable proportions, under the direction of Lawrence Arnold, of New York. At least five and sometimes fourteen performances a week were given at each of our American hospitals in France - and with a complete change of program each week even to the Pathé weekly news, which was purchased and sent overseas by the Westchester County (N. Y.) Chapter of the American Red Cross as its own special contribution. But I think that the most interesting feature of this entire work - and the most human - was the ingenious scheme by which the projectors were so adapted as to throw the pictures upon the ceilings of the wards and so give an untold pleasure and diversion to the tedious hours of our boys who were so completely bedridden as not to be able to even sit erect. And there were many such.

We have drifted for the moment quite away from Vichy and the lovely blue and white and gold theater of our Red 
Cross in the heart of that ancient town. While it was headquarters, it was, after all, but part of the American Red Cross show there; because while our Red Cross recognized that the biggest part of its job was taking care of the enlisted man it was by no means blind to the necessities of his officers. Which led to the regeneration - moral and otherwise - of still another well-known gambling place in the town - the smart casino in the center of the park. This became, quite quickly and easily, an officers' club for the A. E. F. One room was reserved ordinarily for the French, while at least once a week the entire place was given over to a dance.

Dancing! Neither the enlisted man nor the officer ever seemed to tire of it. Each week also the enlisted men piled up the tables and the chairs in their hut and conducted a dance of their own, of which one of the chief features was ice cream - not fox-trotting. As in the huts and canteens elsewhere across France there were never nearly enough girls to serve as partners for the men. But there were no "wallflowers." The floor manager always carried a whistle. A number of times during the progress of each number he blew it - as a signal that the men lined along the walls were privileged to "cut in" on those already dancing. And on the occasions when some restless, impetuous boy blew a whistle of his own and seized the first partner available there was ever a delightful confusion.

Yet with all these things it could not be said that life in the hospital center was exactly an even round of social events; yet it rarely ever ceased for long to be dramatic. Take that November evening when twenty-seven hundred of our boys who had been prisoners of the boche came slipping into Vichy. Their uniforms were filthy and ragged. Slung from their shoulders were the Red Cross boxes such as had sustained them not only during their incarceration in Germany but on their long journey out of that miserable place. 
The limited capacity of these Red Cross boxes for our imprisoned men had precluded their containing much more than mere food necessities. And the boys in the ragged uniforms were hungry, not only for food of the "homecooked" varieties, but for everyday human associations. They had both; even though the hut and the casino each worked steadily and for long hours six wonderful nights in succession. Nearly four thousand miles away from home, every effort was made to make this home-coming into Vichy from the neutral gateways of Switzerland a real one.

These prisoners, as well as the greater numbers of the wounded, arrived with practically no personal possessions. The army promptly re-equipped them with uniforms, but the job of the Home and Hospital Bureau of the Army and Navy Department, which had this particular part of the big Red Cross job as its very own province, was to anticipate and look after all of their personal necessities. This thing it did, and its representatives coöperated with the army officers in studying the most urgent requirements and finding the very gifts which would provide the greatest proportion of real comfort.

Come back, if you will, once again to statistics. I make no apologies for introducing the flavor of the official report into this narrative from time to time. Reports ofttimes are indeed dull things; but the reports of almost any department of the Red Cross have a real human interest even when they seemingly deal with mere percentages and rows of figures. Take a hospital which solemnly reports that 175,872 hospital days have been given to the army in the short space of four months. That fact can hardly be dismissed as a dull statement. It carries with it pictures of white wards, of the capable hands of nurses, of the faces of brave boys in long lines along the ways of an institution which modestly confesses that it holds but a mere fifteen hundred beds.

Because the following excerpt from the report of a Red 
Cross captain at Vichy carries with it a picture of the boys who straggled into the local headquarters asking for everything from socks to chewing gum, it is set down here:

"During the month of October (1918), 78,278 packages of tobacco, 7,480 tubes of tooth paste, 7,650 toothbrushes, 3,650 combs, 3,460 Red Cross bags, 2,850 packages of gum, 1,650 cakes of soap, 1,250 pipes, 1,560 handkerchiefs, 1,245 cakes of chocolate, 1,200 packages of shaving soap, 950 pencils, 1,000 boxes of matches, 900 shaving brushes, 500 packages of playing cards, 450 washcloths, 400 sweaters, 350 razors, 350 boxes of talcum powder, and various smaller amounts of pens, ink, malted milk, razor blades, checkers, thread, games, pipe cleaners, scissors, and drinking cups were distributed free; chiefly, so far as we know, to penniless boys. As this is written, this office is having a thousand applicants a day and, while all their wants cannot be met, no one leaves empty-handed. . . ."

"No one leaves empty-handed. ..."

The boys who marched across the snow-blanketed park at Vichy that January morning with their crimson-crossed bags in their hands, were, after all, only typical of many thousands who had gone before. For three days they had anticipated their evacuation by asking for writing paper, for souvenir postals, for pocket song books, for gloves, sweaters, and the rest of the usual output of the Red Cross - the variety of whose resources would put a modern city department store to the blush. One youngster came to the headquarters on the last day holding his trench cap in his hand.

"It's too dirty for the trip home," he said. "Can't the Red Cross get me a new one?"

No, the Red Cross could not duplicate the work of the army's quartermasters, but it could, and would, help the boy out. So it gave him a cake of soap and showed him how he could clean his greasy cap quite thoroughly and then dry it on the office stove before starting on the march across the park. 
The difficulties of keeping up a full stock of Red Cross supplies of every sort in a land and in times when shipping space of all kinds was at a great premium should be obvious. Of necessity surgical supplies took precedence over luxuries of every sort. Then it was that such places as Vichy and Savenay and all the rest of them had to depend, not alone upon their normal receipts, but upon the resourcefulness of individual workers and the fruitfulness of the surrounding country. That was the reason why in one instance when Red Cross bags could not be shipped into Vichy, they were manufactured there by the thousands by French needlewomen. Indeed no doughboy should leave "empty-handed." Near by districts for a considerable number of miles roundabout were invaded by automobiles seeking the bright-colored cretonnes, which make the bags so very gay and, in turn, so much the more welcome.

On at least two other occasions the vicinage was similarly combed for emergency supplies - for the American celebrations of both Thanksgiving Day and Christmas, 1918. Much was made of both these glorious Yankee holidays. The time was propitious for real celebration. Peace was not only in the air, but at last actually accomplished. The hearts of men were softened. One could sing of "peace on earth" and not choke as the words came to his lips.

So it was that Christmas Day at Vichy was a particularly gay one - gay, despite even the pain and suffering that remained in all the great hospital wards there. For men - American men, if you please, could, and did, hide for the nonce their fearful suffering. Pain begone! The carols were in the air. The hundreds of gayly decorated electric-light bulbs were flashing on at dusk. And you might go from ward to ward and there count all of fifty Christmas trees - these, too, brilliantly decorated. And the decorators in all these instances had been Red Cross women and men - and wounded soldiers lying ill at ease in their hospital cots. They made a great job of all of it - a merry job as well. And when the supplies of such 
conventional raw materials as tinsel and popcorn fell short they seemed to find something else that did quite as well.

For that hospital celebration among our wounded men at Vichy just 13,657 socks were filled, which bespeaks the exact number of doughboys that participated in the celebration. If they could have spoken, each of these humble articles of clothing might easily have told a double story - the tale of its own origin and the romance that came to it after that memorable Christmas Day; for they were American knit socks, and no factory - no inanimate, impersonal place, peopled with machines rather than with humans - had turned them forth. Each and every one of them were hand-knitted. And some of them had come from my lady's parlor, situated in an upper floor, perhaps, of a great and gaudy apartment house, and some had come from the prairie ranch, and some had come from cabins upon the steep and desolate mountainsides of the Alleghenies or the Rockies or the Sierras. From East and West and North and South they had come - but all had come from the United States; and I am perfectly willing to predict that every blessed one returned forthwith to the land of its birth.

The mate of each one of these 13,657 socks was rolled and placed in its toe. Then followed other things - shaving soap, cigarettes, tobacco, nuts, candy, handkerchiefs - by this time you ought to know the Red Cross list as well as I. While, by connivance with the head nurse of each of the wards, each blessed sock was individually tagged and addressed to its recipient. There is nothing, you know, like personal quality in a Christmas gift.

If, after the perusal of all these pages, you still insist upon being one of those folk who regard the triumph of our Red Cross in France as one of American organization, rather than of American individualism, and American generosity, permit me to explain to you that in the paragraphs of this chapter you have slipped from the work of 
the Bureau of Hospital Administration to that of the Home and Hospital Bureau of the Army and Navy Department. The distinctly medical and surgical phases of the Red Cross work in the A. E. F. hospitals across France was a major portion of the burden of Colonel Burlingame's job; the more purely recreative and comfort-giving phases came under Majors J. B. A. Fosburgh and Horace M. Swope, both of whom served as directors of the Army and Navy Departments during the Gibson régime. But the distinction between these two departments was almost entirely one of name. Each, after all, was American Red Cross and as American Red Cross worked - to a common and unselfish and entirely humanitarian end.

If I have lingered upon Vichy it has been because its story was so nearly the story of the Red Cross work in other A. E. F. hospitals across France. The narrative of each differs as a rule only in the most minor details. Sometimes, of course, the unexpected happened, as at Neaves, where our Red Cross under emergency served a double purpose. During the October, 1918, drive, when the American Army was functioning to its highest efficiency and in so functioning was, of necessity, making a fearful sacrifice of its human units, this hut was taken over by the Medical Corps of the army and fitted out as an emergency ward, with ninety-five cots. For six weeks it so served as a direct hospital function.

In the great Base Hospital No. 114 at Beau Deserte just outside the embarkation ports of Bordeaux and Bassens - our Red Cross not only served from 1,200 to 1,500 cups of coffee a day in its huge hut, but actually maintained an athletic field, in addition to the billiard tables which were an almost universal feature of every Red Cross hut. And at another base hospital in that same Bordeaux district, several companies of evacuated men were being told off into groups of a hundred each - and each in charge of a top sergeant - ready to sail on the fol- 
lowing day. Then, just as the men were about to march to the gangplank of the waiting steamer, one of their number fell ill of the scarlet fever and the entire group had to be quarantined. It was one of the many jobs of the Red Cross force there to keep these restless and disappointed men amused and as happy as possikle, and in turn necessary to use a little philosophy.

Philosophy?

One Red Cross girl down there at that particular time told me how she had experimented with it in that trying instance. Her eyes sparkled as she announced the results of the experiments.

"It worked, it really worked," she said. "I found a group of colored men, and upon that group used all the scientific new thought that I might possibly bring to my aid, and with real success. The men were mollified and a bit contented, so that one of them - I think that back in the Middle West he had been a Pullman porter - finally came to me and said:

" 'Missy, I's a-found our hoodoo. Sure what could we expect when we've got a cross-eyed nigger preacher in our squad?" " 


\section{CHAPTER $X$}

"PACK UP YOUR TROUBLES IN YOUR OLD KIT BAG"

"W OUNDED yesterday ; feeling fine to-day."

How many times that message - varying sometimes in its exact phrasing, but never in its intent - was flashed from France to the United States during the progress of the war never will be known. It was a lie of course. Would any sane mother believe it, even for a minute? But it was the lie glorified - the lie idealized, if you will permit me to use such an expression. And it was the only lie that I have ever known to be not only sanctioned, but officially urged, by a great humanitarian organization. For the Red Cross searchers in the American hospitals in France were not allowed to write to the folks at home in any other tenor. Little scraps of messages muttered, perhaps, between groans and prayers, were hastily taken down by the Red Cross women in the hospitals, and by them quickly translated into a message of good cheer for the cable overseas. Any other sort was unthinkable.

Here was a typical one of these:

"Wounded yesterday in stomach — feeling fine. Tell mother will be up in a day or two."

Would you like to look behind the scenes in the case of this particular message? Then come with me. We are "behind the scenes" now - in the dressing room which closely adjoins the operating room in a big American evacuation hospital not far from Verdun. They had done with him on the operating table - for the moment. One operation had been performed, but another was to follow quickly. In the meantime, the soldier boy - he really was not much more than a boy - sat straight upward on 238 
his cot and watched them as they pulled the tight, clinging gauze from his raw and tender flesh. All he said during the process was:

"Do you think that I could rest a minute, doc, before you do the second one?"

He got his momentary rest. And as he got it, sat, with a cigarette between his tightly clinched teeth, and dictated the letter home which you have just read.

Another Red Cross girl walking through one of the wards of that same hospital near Verdun stopped at the signal of a wounded man who lay abed. He was a very sick-looking man; his face had the very pallor of death. And his voice was very low and weak as he told the Red Cross woman that he wanted her to write a letter for him to his wife back in a little Indiana town.

"Tell that I'm wounded - just a little wounded, you understand. Got a little shrapnel in my legs, but that I'll be home by Christmas. Did you get all of that?"

The girl nodded yes. She took the notes on a bit of scrap paper mechanically; for all the time her eyes were on the face of the man. All the time save once - when they fell upon the smooth counterpane of his bed, then returned to the man's face once again. She knew that he was lying, and because she was new, just come over from America - she did not know that the Red Cross held one particular lie to be both glorified and sanctified - she folded up the memorandum, told the wounded man that she would write the letter - and went out.

She went straight to the records room of the place. Yes, it was true. Her suspicions as to the unnatural smoothness of that counterpane were confirmed there. The man had had shrapnel in both legs, but that was not all. Both had been amputated - well above the knees.

The Red Cross girl went back to him, her eyes blazing with anger. Her anger all but overcame her natural tenderness. 
"I can't, I can't," she expostulated. "I can't send that letter."

"Why can't you?" he coolly replied.

She faced him with the truth.

"Well, what of it?" said he. "If I do get home, I'll get home by Christmas - and that will be time enough for her to know the truth. She'll be ready for it, then. But - " he lowered his voice almost to a whisper - "I'm not going to get home. The doctor's told me that, but he don't have to tell me; I know it. And if I don't get home she'll never be the wiser- You write that letter, just as I told it to you."

Here was by far the saddest phase of the Red Cross work for our soldier boys - and almost the most important. It was one thing for the girl in the steel-gray uniform, with the little crimson crosses affixed to her shoulders, to play and make merry with the wounded men who were getting well; but it was a different and vastly more difficult part of the job to play fair, let alone make merry, with those who were not going to get well; who, at the best, were to shuffle through the rest of their lives maimed or crippled or blind. Yet what an essential part of the big job all that was! And how our girls - moved by those great fountains of human love and sympathy and tenderness that seemingly spring forever in women's hearts, rose to this supreme test over there! And after they had so arisen how trivial seemed the mere handing out of sandwiches or coffee or cigarettes! This was the real touch of war - the touch supreme. After it, all others seemed almost as nothing.

Early in the progress of the conflict our Red Cross foresaw the great necessity that would be coming for its acting as a medium of communication between the doughboy and his folks - three thousand miles or more away. The United States Army had made little or no provision to meet 
this need; it had far larger and far more immediate problems ahead of it. And so about the best that it could be expected to do would be to notify the folks at home that their boy had made sacrifice - supreme or very great for his country; at the best, a sort of emotionless proceeding upon its part. In the meantime there was hardly a waking hour that those selfsame folks were not thinking of the boy in khaki. While if anything happened to him - serious even, but not quite serious enough to justify the setting of the somewhat cumbersome machinery of the army's elaborate system of notification into motion - both he and the folks were helpless. France is indeed a long, long distance away from the United States. Three thousand miles is a gap not easily spanned.

But it was the job of the American Red Cross to span that gap; not only to bring news of the boy to the home folks, but, in many, many instances, to bring news of them to him. The one thing was nearly as valuable as the other. And while in the elaborate organization of the American Red Cross they were operated as separate functions and bureaus, their work in reality was so interwoven that in the pages of this book we shall consider them virtually as one, and shall begin a serious consideration of this important phase of Red Cross work by calling attention to a very few of the ramifications of a hospital searcher's job. First and foremost her task was to tell those same home folks all that she could pen, or typewrite, about their own particular soldier - exactly where he was at that time and just how he progressed. The ordinary method of handling the vast volume of these messages was in the form of short, concise, personal reports which passed through the Paris headquarters of the American Red Cross and were forwarded by it to the National Headquarters at Washington, where they were made up into letters and forwarded to the families. There were, of course, many variations in this method; for instance, when it was advisable for Paris to write direct to the boy's parents, and in those other cases, which you have al- 
ready seen, where the letter to America went direct from the Red Cross worker's room at the hospital. The choice between these methods was left quite largely to the individual worker who, in turn, weighed each situation and its necessities, individually and separately.

It was only in these last instances that the lie was sanctioned and even permitted, and even then only upon the absolute demand of the wounded man, himself. He had all the rights in such a situation, and the Red Cross bowed to and respected those rights - in every case.

The Red Cross reports through headquarters were accurate - invariably, and, at first sight, generally unemotional. Here is one of them that is quite typical:

"Private Edward Jones - 20th Regiment, Company $\mathrm{H}$ - has been wounded in both legs. Wounds painful, but amputation not necessary. In excellent spirits sends love to family."

Short, to be sure. But to a newsless family three thousand - perhaps six thousand - miles away, with its necessary detail, tremendously satisfying.

Return with me if you will for a final visit to Vichy. No group of Red Cross workers anywhere held a more sacred responsibility than the women who were stationed there. Day in and day out they passed through the white lanes of wards in the military hospitals and each day looked - and looked deeply - into the hearts of the American boys that lined them. Heart and soul these women of the steel-gray uniforms were at the service of our wounded soldier men - at their very beck and call, if you please. And when of a morning a bed here or a bed there was empty, the searchers understood, and prepared to write a letter - a scant matter of sympathetic record at the best - that somewhere back in America would at least relieve the tension of waiting.

Some of the messages that these searchers sent were as you already know - full of gladness; thank God for 
them! Others warned gently - the boy was coming home with his face forever scarred or his limbs or his eyes gone. Still others told - and told again and again - of the brave and the battling soul that finally had slipped away into the eternal mystery of the Valley. Each of these last held between its tiny pages a single flower - plucked at the last moment from the funeral wreath.

Let me quote from one of these letters of a Red Cross searcher.

"I am constantly on duty here," she says, "and visit. your brother Harry almost daily. He has been unfortunate enough to have been wounded in the right leg, which the doctors found necessary to amputate just below the knee. I know this will be a great shock to you, but let me hasten to add that Harry is in the best of condition otherwise. The wound is healing marvelously clean and quickly. He is in the healthiest and happiest frame of mind and exceptionally cheerful. Harry wants me to tell you that the last dressing of the wound was yesterday. He expects to be up and trying his crutches within ten days. He received your September money order of ten dollars for which he thanks you very much. I have just cashed it for him. . . . I am sorry to be the bearer of this sad news, but am happy that I can assure you of his early recovery and his splendid courage."

Men who were able to write for themselves were supplied with paper and encouraged to do so. Others who were far too ill or confined prone in surgical apparatus - their very hands caught and held taut in a cruel network of pulleys and weights and drain tubes - dictated their letters home - and invariably lied as to their condition. All was "going well." The patient sufferer had but one report to pass his lips. "Tell them that I'm feeling fine," was the message that he ordered home.

Sometimes by piecing together information culled from a variety of sources, the searcher was enabled to reconstruct the picture of the last hour of some soldier's life. Com- 
rades would recount the story of his death at the front or describe the moment of his capture by the enemy. In fact persistent questioning revealed such facts as finally cleared up the doubt as to the fate of a certain Yankee corporal. It happened that the boy had disappeared in April, 1918. It was a number of months afterward that a patient was discovered at a port of embarkation who said:

"Yes, he was killed when the Germans were attacking and a heavy barrage was coming over. They came around back of us and threw hand grenades from the rear. Corporal — pulled his pistol and yelled: 'Here they come, boys! Give it to them!' He was awfully generous. He used to get a lot of scrapbooks and pass them around to the boys. When he got a box from home he shared it. He was a mighty generous fellow about lending money, too."

The women who made those scrapbooks and packed those boxes of "goodies" can have no memento from his grave over there, but here was the sweet memory of his courage and his generosity. Think of the comfort that her woman's soul must have found in that frank, outspoken boyish tribute and the relief at finally having had at least the definite information of the truth! So it was that our Red Cross searchers gave constant and almost invaluable aid in revising and verifying the casualty lists of the army; and many who were accounted missing - that dread term that means nothing and yet can mean so much - could, because of their work, be accurately enrolled as dead or as prisoners.

$A_{s}$ far back as the summer of 1917 five women had been definitely assigned to this activity - not at Vichy then, but at the American army hospitals which already were beginning to multiply in France. By December of the following year this staff numbered nearly two hundred women, who worked either in the hospitals or in the American Red Cross headquarters in Paris. And while these worked in the hospitals, the Red Cross officers in the field men serving as searchers, chaplains, or Home Communica- 
tion representatives - were working in close coöperation with the statistical officers of the army. These were stationed in training camps and concentration camps and with various combat divisions. Ten men were assigned direct by the Red Cross to the Central Records Office of the Adjutant General's Department of the A. E. F.

Understand very clearly, if you will, please, once again, that while in very rare cases our Red Cross did announce casualties, that, after all, was not its real province. To engage in that would have been a mere duplication of the army's own work. Mortality letters were not sent direct to the nearest of kin; they were forwarded to the A. E. F. Central Records Office in France for final disposition, so that their release through the mails would not anticipate the official announcement from the War Department; while the other information, in most instances, was reported to the Paris headquarters of the American Red Cross and was later disseminated here in the United States from the American Red Cross headquarters in Washington.

The lists of the missing soldiers were furnished by the army. Duplicates of these were then immediately distributed to the Red Cross searchers and representatives, who at once sought clues to the individual stories to be builded about the name of each man. Sometimes through arrangements with the army authorities the boche prisoners were interviewed, and these occasionally furnished facts with reference to American prisoners in Germany and gave definite information about aviators who had apparently disappeared within the enemy lines.

Incorporated in these lists of the missing were also the names of all soldiers and sailors concerning whom inquiries had been made of our Red Cross either here in America or over there in France. In the one case these inquiries and in the other through the Paris headquarters in the Hotel Regina. In one month 1,955 cables were sent across the Atlantic from the United States requiring immediate information regarding wounded or missing men. In Decem- 
ber, just following the armistice, the Paris office received more than a thousand individual requests for news of the doughboys. Almost literally these came in floodtides; but none was ignored or forgotten. It made little difference, either, as to whether any of them was addressed. The Red Cross cleared its mail with a good deal of efficiency and promptness. Its huge central postoffice in Paris was a marvel of precision - and it had at all times a difficult job. Yet it so happened that it was in charge of a man without any previous experience in such a task - Senator Henry Brevoort Kane, of Rhode Island. It chanced that Senator Kane displayed an immediate adaptability for the joband with this, combined with great patience and persistence, he made a real success of it.

Perhaps the most satisfactory part of the searcher's job was in many ways the search for missing men - by interviewing the boys in the hospitals about their friends and intimates, getting tremendously tiny details about these in camp or in battle, or even in the hospitals themselves, and from these details evolving the web of evidence - Conan Doyle or E. Phillips Oppenheim could hardly have had a more fascinating time of it than did some of our Red Cross women in unraveling the tangle of confusion which they found wound about this boy or that, or the other fellow. Many an agonizing situation, indeed, was cleared up through the efforts of these men. And such times were almost the sole relief from a task that frequently was dreary and almost always distressing.

If you would the better understand the real task that these women faced, permit me to quote from a letter written by one of them:

"The most entertaining part of my work is writing letters home for the wounded boys. In answer to my letters the replies that come back are more than adequate reward. The letters come from farmhouses in Vermont, from factory towns in Connecticut, from busy Massachusetts cities, and from lonely Western ranches. They are pathetic, sad, 
funny; but all of them are overflowing with surprises and gratitude for the person in the mysterious 'over there' who had taken the trouble to visit and write home for her 'particular boy' after he was wounded. These letters for the boys were usually written to a woman - mothers, sisters, or 'girls' the favorites first, of course, although occasionally 'aunty' or 'teacher' came in for a message of reassurance.

"The first letter I had to write was for a boy who had lost his right eye. He wanted me to write his girl, whose photographs I had seen several times. She had very fluffy hair and usually seemed to stand in an apple orchard. After this he made a rather staggering suggestion: Would I please read all of Alice's letters so that I should know what kind of a girl she was and so answer her letters better! Realizing that a Red Cross worker should flinch at nothing and trying not to think of Alice's feelings in the matter, I took the letters out of a bag at the head of his bed and plunged into the first one.

" To my intense relief they all began 'Dear Bill,' and ended 'Your true friend, Alice.' Her only reference to matters of the heart was the hope that he would not fall in love with any of those pretty Red Cross nurses over there. For the most part Alice seemed to prefer impersonal topics, such as the potato crop, the new class, and the party at the grange Saturday night. Bill thought she was a mighty fine writer and, I think, was a little worried lest I be unable to compose a letter worthy of her. He was worried, too, about the best way to tell her that he had lost an eye. 'You know, I don't care. The left one is working better than it ever did and I know it won't make no difference in the way she thinks of me, but she'll feel pretty bad for me, I know that, and I want you to please tell her about it real gentle.' We finally decided to tell her in this letter that he had been seriously injured in his right eye and then, in the next letter, which he would write himself, he would tell her it was gone. 
"In due time I received a grateful note from Alice in a very long, elegant, and exceedingly narrow envelope inclosing a correspondence card covered with high-schoolishgirlish writing. ' Thank you so much,' she wrote, 'for your letter giving me news of Bill, who I was getting so anxious about, as I had not heard from him for so long. I am glad he is getting better and that he really is not suffering.'

"Another grateful letter came from the mother of Michael Holihan. Mike had been badly wounded and at first no one thought he could possibly pull through, for he had a piece of shrapnel in the liver. He survived the operation, however, and became very anxious to write his mother. ' Now you just please write her what I tell you,' he said. 'Mother is pretty old now and she is always worrying, but I got it all thought out just what I am going to say to make her stop.' This is what he dictated:

\section{" Dear Mother:}

"I I was hurt the other day but not enough to keep me down very long and I am as well as ever now. They certainly do use me fine in this hospital. I am having a great time. Gee, I am a happy boy, and don't you worry none about me, mother.

\section{" 'Your son,}

\section{"'MIne." "}

"After making this effort he lay back on the pillow and shut his eyes for a moment, tired out, only to open them anxiously to ask: 'That'll fix her, won't it?' Apparently it did not entirely ' fix her,' for her answer came back to me - an anxious scrawl - 'I received your letter and, dear Red Cross lady, it was so kind of you to write when you must be so busy and let me know how my son was getting along, as I was waiting day after day for a letter from him and I didn't know what could be the matter as he always writes regularly like the good son he is. I am worrying day and night and even if Mike did say I shouldn't because what do boys know about it if they are 
sick or well and my Mike would say that he was well if he could only lay flat on his back and look at the ceiling he would. As this is all I have to say, I will bring this letter to a close. Tell Mike, I and all the family have wrote him!"'”

Our Red Cross as well as our army officers, themselves, recognized almost from the beginning that an untroubled soldier always is the best soldier. It also appreciated - as this book already should have told you - that its primary object in Europe was to bring the utmost comfort and relief to America's fighting millions. That was why, in the early summer of 1918, it issued a small pamphlet telling the doughboy to "pack up his troubles in his old kit bag" and to hand them to the first Red Cross representative he met. He was assured that there was no worry of any kind, either on the one side of the ocean or the other, that the Red Cross could not or would not shoulder for him. These pamphlets were printed by the hundreds of thousands and distributed to every American soldier in France. And they were an evidence of the real desire of the great organization of the crimson cross to make itself invaluable, not alone in the comparatively few large ways of succor, but in an almost infinite number of smaller and individual ones. It was in this last sort of help, of course, that the Home Communication Service shone. It was its own particular sort of a job to take from the harassed minds of individual soldiers their individual problems - as varied and as complicated as the temperaments and the conditions of the doughboys, themselves. Take a single instance:

Here was a man who was owner of a small but growing business in the Mohawk Valley of New York State. When a unit was being recruited near Utica and a call for volunteers was being issued, he responded - with instant promptness. At the time he donned the khaki the two banks in the little town from which he came held notes against his business for a sum of a little more than a thou- 
sand dollars. They had been indorsed by his brother, a hard-working farmer of the valley.

Before this boy had been mobilized he arranged to have his young wife conduct the business - with the aid of his long-time assistant. The banks told him that the notes would, in no event, be called before his return from the service of his country. They were fairly perfervid in their expressions of their desires for patriotic service, and the young man left for France, his mind well at ease.

His first letters from home were full of optimistic comfort. A little later, however, they were not quite so serene. Finally this soldier received a letter from his wife stating quite frankly and without reserve that the two banks had called the loans, forced his brother to sell part of his farm stock, and then had sold out their little business.

The boy in khaki was furious. A week before he had stuffed into his musette the little American Red Cross booklet which told of that organization's sincere desire to help the individual American soldier who found himself in trouble. "I'll take them at their word," thought he and immediately sought out the Red Cross man with his unit, and to him spilled the entire story. The Red Cross man boiled. He was not a young man - being a bit too old for regular army service, he had taken the Red Cross way as being the best for him to serve his country - and he had heard stories of that sort before, and decided to take prompt action on this one.

It so happened that there were some pretty big American bankers on the American Red Cross staff over there in France. When this incident was rushed through to them - with vast promptness - they, too, took action. They did not even wait for the mails, but cabled the main facts of the story to the secretary of the American Bankers' Association, saying that the proofs were coming on by post, but requesting immediate action. A representative of the Association took the first train up into central New York and, through a personal investigation of the books of the two 
banks, quickly verified the incident - in every detail. After that he promptly returned to New York city and, placing the matter before the executive committee of the Bankers' Association, asked that justice be quickly done. It was. The two miserly and hypocritical banking institutions were forced to return the young soldier's business to his wife and to pay back the brother the money which they had taken from him. After which they were both kicked out of the national association.

Along with the pamphlet advising the doughboy to pack up his troubles in his old kit bag and then carry them to the nearest Red Cross man or woman, there was prepared a poster originated by a man out in the Middle West, who because of his understanding affection for boys was particularly well qualified to prepare it. It was used to placard Brest and some other port towns. As I recall it, it read something like this:

\section{American Soldier and SaIlor}

Are you worried about anything back home; your wife, children, mother, insurance, allotments, taxes, business affairs, wills, powers of attorney, or any personal or family troubles of a private nature?

\section{The American Red Cross Home Service Men}

will help you by cable, telegraph, letter - assisted by forty million members of the Red Cross at home. Information Free.

Troubles? The American doughboy seemed to have all the troubles that the poster catalogued - and then some more. The response to the poster and the pamphlet was immediate. Soldiers sought out the American Red Cross Home Communication people all over France. At Brest the first office was in a tent near Camp Pontanzen. Later two offices were established. One, for the sailors, was located in Brest itself, and fairly accessible to the landing stages. Another was located in a stone barracks that had been builded by the great Napoleon. This office not having 
an outside door available to passers-by, wooden steps were built up the wall to a French window. Another set of steps was affixed to the inner wall and led right down to the desk of the Red Cross representative. Eventually this work at just this one point became so great in volume that four of these offices were pressed into service.

"What does Home Service really do for a man?" asked a magazine woman who was " doing " France for her publication at one of these offices. The answer to her inquiry was definite.

"It does everything," they told her, "from giving a soldier a needle and thread to letting our tears mingle with his between sobs when he tells us of his home troubles."

Upon the request of our men, wills in proper form were drawn up by Red Cross attorneys and forwarded to the men's families in this country. There were men with wives not only in the United States, but in every corner of the world - in Russia, in Assyria, in Italy, for instance - who wished to be assured that their allotments from the government were being delivered. During the influenza epidemic here and at a time when the flames of a forest fire were winging their way across great spaces in our West, the American Red Cross offices in Paris were besieged with tragic appeals for immediate information from home.

In some of the army divisions the movements of troops were so sudden and so uncertain that mail was badly delayed. Then the doughboys begged our Red Cross for reports from home and our Red Cross furnished them through its service here.

"Our visitor found daddy and your wife and baby at luncheon," read one of these reports from America. "They had roast chicken, stewed tomatoes, mashed potatoes, hot bread, and jam. ... Y Your wife is teaching school. . . . The B- family has moved. . . . Your mother has one boarder and the crops are fine. . . . Willie and Carrie are going to move away in the spring." 
Can you imagine what such a report might mean to a man who had not heard from home in over five months? There were many such. There were times when men American fighting men - "went over the top " with aching hearts for some one who faced a particularly difficult problem of life back here at home. Then it was that the Red Cross did not hesitate to use the cable. It is hardly necessary to emphasize the relief which the following exchange of messages must have meant to some one fighting man in our khaki:

To AMCROSS, Washington:

Paris, August 6, 1918.

Report concerning confinement, Mrs. Harold W-, Rural Free Delivery Five, $\mathrm{H} \longrightarrow$ - Penn.

\section{To AMCROSS, Paris:}

Washington, August 14, 1918.

Answering Inquiry No.- Mother and baby son three months old well and happy.

In this instance the worried fighter was an officer - a captain of infantry. During the time which elapsed between the two cablegrams he was wounded and the answer found him in a hospital, side by side with a French blessé. A Red Cross searcher acted as interpreter for their felicitations and in her official report of the incident included this notation:

"Captain W- was much improved as a result of the good news. He is sitting up and eating roast chicken today. He says the American Red Cross has cured him." The Red Cross representatives here in America could not enter a home unless they were welcome; neither could they force their way into the hearts of men. They were compelled to wait until their help was sought. The growing mental depression of a certain major of a fighting division during those tense months of the midsummer of 1918 did not escape the attention of the American Red Cross man attached to that division. Suddenly the man, who had been marked because of his poise, became taciturn - isolated 
himself. 'A' reference to the Red Cross Home Service which its division worker tactfully introduced into the table talk at the mess at which both sat, however, did elicit some trivial rejoinder from the man with the golden oakleaf upon his shoulder; while the following day that same major wrote a letter to the Red Cross man - and bared the reason for his most obvious melancholy.

It seemed that back here in the United States he had a little son, from whom he had received no word whatsoever in more than six months. The child was with the major's divorced wife, and his father was more than anxious to know if he was regularly playing out of doors, if he was receiving his father's allotment, and if he was buying the promised Thrift Stamp each week. The army man already had his second golden service stripe and greatly feared that his little son might be beginning to forget him.

Under conditions such as these, visiting the boy was a diplomatic mission indeed. Finally it was intrusted to the wife of an army officer. And because army officers' wives are usually achieved diplomats if not born ones, the ultimate result came in weekly letters from the boy, which not only greatly relieved his father's mind but greatly increased the bonds of affection between the two. The Greatest Mother in the World is never above diplomacy which is, perhaps, just another way of expressing tact and gentleness.

There were many, many occasions, too, when the relatives at home depended upon that selfsame diplomacy of hers to tell the disagreeable stories of losses or perhaps to prepare the boys overseas to face an empty chair in the family circle. There was one particularly fearful moment when a brilliant young officer had to be told that the reason why his young wife had ceased to write was because she had gone insane and specialists believed that she could not recover. Boys were driven to Red Cross offices by hidden affairs that flayed them hideously and of which they wished to purge themselves. Some wanted to set old 
wrongs right. Others had fallen blindly into the hands of the unscrupulous and had only fully awakened to see their folly after they actually were upon the battlefields of France. Then there were the softer phases of life - the shy letters and the blushing visitors who wished to have a marriage arranged with Thérèse or Jeanne of the black eyes and the delicate oval face. I remember one of our boys who had fallen in love with a girl in Nancy. Theirs was a courtship of unspoken love, unless soft glances and gentle caresses do indeed speak more loudly than mere words; for they had no easy bond of a common tongue. His French was doughboy French, which was hardly French at all, and her English was limited. So that after he had gone on to the Rhine and the letter came from her to him in the delicate hand that the sisters at the convent had taught, he needs must seek out Red Cross Home Communication and intrust to it the task of uncommon delicacy, which it fulfilled to the complete delight and satisfaction of both of them. For how could any mother, let alone the Greatest Mother in the World, blind her eyes entirely to love?

She apparently had no intention of doing any such thing. For how about that good-looking doughboy from down in the Ozark country somewhere, who arrived in Paris on a day in the autumn of 1918 with the express intention of matrimony, if only he knew where he could get the license? French laws are rather fussy and explicit in such matters. Some one suggested the Home Service Bureau of the American Red Cross to the boy. He found his way quickly to it - with little Marie, or whatever her name really was, hanging on his arm. A Red Cross man prayerfully guided the pair through the legal mazes of the situation. First they went to a law office in the Avenue de l'Opera where the necessary papers were made out; then the procession solemnly moved to the office of the United States Vice Consul at No. 1 Rue des Italiens, where the signature of the American official representative was duly affixed to each of 
the papers; after which to the foreign office, where the Freneh went through all the elaborate processes of sealings and signatures which they seem to love so dearly, and then - the work of Mother Red Cross was finished. They were quite ready for the offices of the Church.

With the signing of the armistice all this work was greatly increased - was, in fact, doubled and nearly trebled. When a man was fighting his physical needs seemingly were paramount; but once off the field, the worries that lurked in his subconscious mind seemed to rise quickly to the surface. He then recalled that long interval since last he heard from home. That troubled him, and he turned to the Red Cross - those pamphlets and posters did have a tremendous effect. And if he had no definite troubles over here, such as those we have just seen, he was apt to be just plain hungry for a sight of the home - and the loved ones that it held.

It was in answer to a demand such as this last that a Red Cross representative right here in the United States took her motor car and drove for a half day out to see a family of whose very existence she had never before even heard; and, as a result of her call, wrote back a letter from which the following excerpts are taken:

"I want to tell you about a never-to-be-forgotten trip that I took the other day out to see a one hundred per cent patriot; an American mother who has three sons in the service. The home is one of the coziest, homiest, friendliest places you can imagine; one story, with that cool spacious plan of construction that makes you want to get a book, capture a chair on the wide, comfortable porch, and forget the world and its dizzy rush; a great sweep of lawn and with some handsome Hereford calves browsing in one direction and a cluster of shade trees nearer the house.

"The hills surrounding the house make a lovely view and all were covered with grazing stock, also the fine Hereford cattle for which the place is known. But the best part of the home is the dear little woman who hung a service flag 
in the window with the name of a boy under each of the three stars. She is the type of mother that draws every one to her; tender, sensible, capable, broad-minded, and with a shrewd sense of humor that keeps things going and makes life worth living for the entire household.

"She took us to a roomy side porch where her sewing unit of the Red Cross meets each Tuesday. A marvelous amount of work has been turned out in that side porch, and I'll wager a dollar to a doughnut that I know the moving spirit of the workers. Off in a big, cool parlor bedroom there were stacked up several perfectly enchanting ' crazy quilts' made by these same busy women at odd moments. These are ready to be sent to Serbia or they may be sold at auction for the benefit of the Red Cross.

"We saw pictures of each boy in the service - one in the navy, one in the heavy artillery, and Milton, whom we all hope is not in the hospital by now. Each boy had in his eyes the same intrepid look that the mother has - one can tell that they made good soldiers. Knowing how busy farm folk are, we reluctantly took our leave after seeing all these interesting things and, as we swung out into the country lane, we looked back and there stood the mother waving and smiling - the very best soldier of them all."

Can you not see how very simple it all was - how very human, too? As you saw in one of the earlier chapters of this book, a fairly formal and elaborate plan of organization had been laid out for all this work; but, perhaps because war after all, is hardly more than a series of vast emergencies, the American Red Cross searchers, either in the field or in the hospitals, could hardly confine them. selves to any mere routine of clerical organization or work in the great task that was thrust upon them. The unexpected was forever upon them.

As a single instance of this take the time when, in the Verdun sector and in the hottest days of fighting that the American Army found there, so many demands were made 
upon our Red Cross by the officers and men of the A. E. F. for the purchase of necessities in Paris that a definite shopping service quite naturally evolved itself out of the situation. The man who initiated that service raced a motor car from Verdun to the Paris headquarters in order to secure the materials necessary for its inauguration. For when the American Red Cross made up its mind to do a thing, it did it - and pretty quickly too.

So it went - a service complicatedly simple, if I may so express it. For, despite its own batteries of typewriters and card indexes, there was, at almost all times, that modicum of human sympathy that tempered the coldness of mere system and glorified what might otherwise have been a mere job of mechanical routine into a tremendously human and tender thing. The men and girls of the Home Communication Service had a task of real worth. Of a truth it was social service - of the most delicate nature. It included at all times not only the study of the physical needs of the soldier or sailor, but also at many times that of his mental needs as well. In reality, it became a large part of the scheme of preserving and enlarging the morale of the A. E. F. Every time a soldier was freed of endless, nagging worry, he became a better soldier and so just that much more strength was added to the growing certainty of victory. 


\section{CHAPTER XI}

\section{WHEN JOHNNY CAME MARCHING HOME}

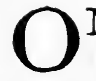

$\mathrm{N}$ November 11, 1918, the armistice was signed and the fighting of the Great War ceased - almost as abruptly as it had begun. And the ebb tide of American roops from Europe back to the United States began ; almost at once. For a time it was an almost imperceptible tide; in the following month but 75,000 soldiers all told officers and enlisted men - were received through the port of New York, at all times the nation's chief war gateway; yet this was but the beginning. Each month of the early half of 1919 registered an increase of this human tide inflowing as against the preceding months, until May, with 311,830 troops received home, finally beat, by some 5,000 men, the record outgoing month of July, 1918, when under the terrific pressure induced by the continued German drive, 306,731 officers and men had been dispatched from these shores. Yet June, 1919, overtopped May. In that month 342,686 troops passed not only under the shadow of the beloved statue of Liberty, but also into the friendly and welcoming ports of Boston, Newport News, and Charleston, while the Secretary of War promised that the midsummer months that were immediately to follow would break the June record. A promise which was fulfilled.

Long before the signing of the armistice, Pershing had ruled that the work of the American Red Cross with the well men of the A. E. F. was specifically to be limited to them while they were en route from one point to another along the lines of communication, as you already have seen in an earlier chapter. To the Young Men's Christian Association was intrusted the chief burden of caring for them in their more or less permanent camps. This meant 
for our Red Cross in the final months of the war - before peace was actually signed and declared - a task almost exactly like that which had confronted it in its very first months of war experience in France. The stations along the railroad lines of eastern France, Luxembourg, and the Moselle Valley - the lines of communication between our French base ports and the occupied districts of the German states - offered to the American Red Cross the very same canteen problems as had once faced it at Châlons-sur-Marne and Epernay. Treves and Coblenz were hardly different from either of these - save perhaps in their increased size.

Because Coblenz is rather more closely connected in the mind of the average American with our Army of Occupation, let us begin with it, here and now. It was, in fact, the easternmost outpost of the work of our Red Cross with our army over there. There the lines of communication officially began, and ran up the railway which ascends the beautiful but extremely tortuous valley of the Moselle. And where the lines of communication began - in the great railroad station of Coblenz - the American Red Cross also began. It had two canteens in that station; one just off the main waiting room, and the other, for the convenience of troops who were merely halted in the train shed of the station while going to and from the other American mobilization centers in that Rhine bridgehead, right on the biggest and the longest of the train platforms. Both were busy canteens ; never more so, however, than just before 10:30 o'clock in the morning, which was the stated hour for the departure of the daily leave-train toward the border lines of France. Then it was the Red Cross coffee and sandwiches, tobacco and chewing gum were in greatest demand; for the long leave-train boasted no such luxury as dining cars, and there was scarce enough time at the noonday stop at Treves for one to avail oneself of the lunchroom facilities in the station there.

Yet Treves for the American Red Cross was a far, far more important point than Coblenz. It was the head- 
(puarters of all its work in Germany, and boasted in addition to the large American Red Cross canteens in each of the two railroad stations, on either bank of the Moselle, and the recreation huts at the base hospitals - for that matter, there were also recreation huts at the base hospitals in and about Coblenz - well-equipped clubs for both enlisted men and officers. Of these the club for the enlisted men - for the rank and file of doughboy - quite properly was the best equipped.

In the beginning it had been one of those large combination beer gardens and music halls that always have been so very dear to the heart of the German. It was the very sort of plant that could be, and was, quickly adapted to the uses of a really big group of men. Its main bierhalle made a corking dining room for the doughboys. The meals kept pace with the apartment. Three times a day they appeared - feeding daily from 600 to 1,600 boys - and they were American meals - in fact, for the most part composed of American food products - meats from Chicago, butter and cheese from New York State, flour from Minnesota, and the like. For each of these a flat charge of two marks - at the rate of exchange then prevailing, about eighteen cents - was made. But if a doughboy could not or would not pay, no questions were asked. The Treves Enlisted Men's Club which the American Red Cross gave the A. E. F. was not a commercial enterprise. It was run by an organization whose funds were the gift of the American people - given and given freely in order that their boys in khaki might have every comfort that money might provide.

The great high-ceilinged halle held more than a restaurant. It was a reading room as well, stocked with many hundreds of books and magazines. In fact a branch of the American Library Association operated - and operated very successfully - a small traveling loan library in one of the smaller rooms of the club. Upon the walls of the vast room were pictures and many maps - maps of the 
valley of the Moselle, of that of the Rhine, of the Saar basin, of the operations in France. These last held much fascination for the doughboys. The most of them were of divisions which had led in the active and hard fighting, and the tiny flags and the blue-chalk marks on the operation maps were in reality placed there by their own efforts but a few weeks and months before. It was real fun to fight the old actions over and over again - this time with talk and a pointing stick.

There were, of course, such fundamental conveniences for roaming doughboys as baths, a bootblack and a barber shop - this last equipped with chairs which the boys themselves invented and constructed; a plain stout wooden armchair, into the back of which a board - not unlike an oldfashioned ironing board - was thrust at an angle. When turned one way this board formed just the proper headrest for a shave; in the other direction it was at exactly the right angle for haircutting.

For the Officers' Club of our Red Cross at Treves, the Casino in the Kornmarkt, the heart of the city, was taken over. The fact that this was in the beginning a wellequipped club made the problem of its adaption a very slight one indeed. And the added fact that officers require, as a rule, far less entertainment than the enlisted men also simplified its operation. As it was, however, the officers were usually given a dance or a show each week - in the comfortable, large hall of the Casino. In the Enlisted Men's Club there was hardly a night, however, without some sort of an entertainment in its halle; and the vast placed packed to the very doors.

The next stop after Treves in the eastbound journey from the Rhine of the man in khaki was usually Nancy. And here there were not only canteen facilities at the railroad station, but a regular Red Cross hotel - situated in the Place Stanislas, in the very heart of the town. In other days this had been the Grand Hotel, and the open 


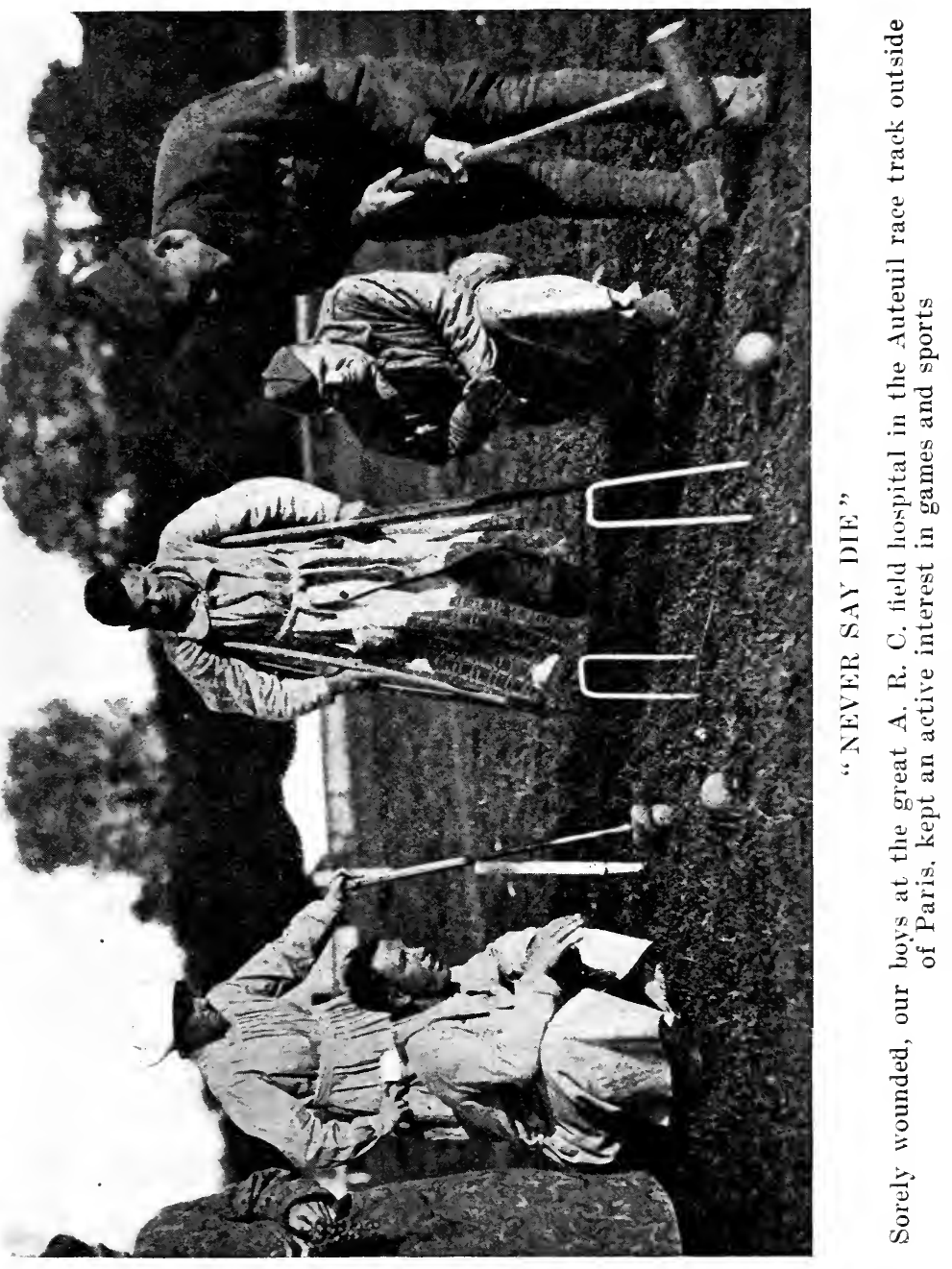



square that it faced has long been known as one of the handsomest in all France. In fact, Nancy itself is one of the loveliest of all French towns; and despite the almost constant aerial bombardments that were visited upon it, escaped with comparatively minor damage.

The Red Cross hotel there was opened on September 30, 1918, and closed on the tenth of April of the following spring - had eighty-eight rooms, capable of accommodating one hundred guests, and two dormitories capable of providing for some forty more. The room charges were invariably five francs for a room - with the exception of one, usually reserved for generals or other big wigs which rented at eight francs a night. For the dormitory beds an even charge of two franes (forty cents) nightly was made, while in the frequent event of all these regular accommodations of the hotel being engaged and the necessity arising of placing cots in its broad hallways, no charge whatsoever was made for these emergency accommodations.

For the excellent meals - served with the fullness of a good old-fashioned Yankee tavern - a progressive charge of four francs for breakfast, five francs for lunch, and six franes for dinner was made. Surely no one could fairly object to the restaurant prices, which, even in France in war-time stress, ranged from eighty cents to a dollar and twenty! In fact it was a bonanza for the American officers who formed the chief patrons of the place - although a bit of thoughtfulness on the part of some one had provided this particular hostelry with a dormitory of twelve beds and a single room with three which was held reserved for American women war workers; an attention which was tremendously appreciated by them.

Eleven miles distant from Nancy was Toul; but Toul we have already visited in the pages of this book. We know already the comfortable accommodations that the traveler in khaki found in the group of hotels and canteens which our Red Cross operated there. There were many of these, 
even outside of Paris; one of the largest the tavern at the badly overcrowded city of Bordeaux. That tavern had been little to boast of, in the beginning. It was an ancient inn indeed; but good taste - the purchase of some few dozen yards of cretonne, and cleanliness - the unrelenting use of mop and broom and soap - had accomplished wonders with it. There were others of these American Red Cross hotels in France during the fighting period - the ones at Dijon, Is-sur-Tille, and Marseilles were particularly popular. But it was in Paris itself that the Red Cross accommodations for the itinerant doughboy in the final months of the war, as in the long and difficult half year that intervened between the signing of the armistice and the signing of peace, reached their highest development. In the beginning these had taken form in canteens which were operated night and day at each of the important railroad stations. These were all right - so far as they went. Their one-franc or seventy-five centime meals were wonderful indeed. I have eaten in these canteens many times myself - and always eaten well. I have been seated between a doughboy from North Carolina and one from North Dakota and been served by a society woman in steel-gray uniform - a woman whose very name was a thing to be emblazoned in the biggest headline type of the New York newspapers, but who was working week in and week out harder than the girls in busy restaurants back home are usually wont to work.

If you would see these canteens as they really worked, gaze upon them through the eyes of a brilliant newspaper woman from San Francisco, who took the time and the trouble to make a thorough study of them. She wrote

"A brown puddle of coffee was spreading over the white oilcloth. The girl from home sopped it up with her dish towel. She brushed away messy fragments of food and bread crumbs. Again there were few vacant places for American soldiers on the benches at the long table in the canteen at the Gare St. Lazare. 
" The canteen, one of a circuit of thirteen maintained by the Red Cross in Paris, had formerly been the corner of a baggage room in one of the most important Paris terminals. The concrete floor bruised her feet. She was as conscious of them as Alice in Wonderland who discovered her own directly beneath her chin after she nibbled the magic toadstool. The girl was tired, but she smiled.

"It was really a smile within a smile. There was one on her lips which seemed to sparkle and glance, waking responsive smiles on the faces of the men. At once the gob who was born down in Virginia and had trained at Norfolk, decided that she was from his own South. The sixfoot doughboy from California knew that she came from some small town in the Sierras. To each of the men she suddenly represented home.

"That smile stays in place each day until she reaches her room in a pension across the Seine on the Rue Beaux Arts. There, closing the door upon the world with its constant pageant of uniformed men who seem forever hungry and thirsty, she lets her smile fade away for the first time that day.

"The smile within is tucked away in her heart with the memory of agonizing moments aboard an ocean liner when she felt her exalted desire for service ebbing away because she feared she would not be needed. Needed! Now she wonders who else could have managed so tactfully the boy who had been at sea for one year and discovered that he had forgotten how to talk to an American woman. His diffidence was undermined with another dish of rice pudding and an extra doughnut. He became a regular boarder at the canteen where breakfast costs nine cents and any other man's size meal may be had for thirteen cents. His leave ended in a half day of excited shopping for which his younger sister will always be grateful.

"The girl from home had been one of those solemn creatures who was called to the Overseas Club in New York for service abroad. She was one of hundreds who had 
clinched their own faith in their ideals by pledging such service. It had been a wrench, saying good-bye at the station in the Middle West. There were no boys in the family, and her father had made a funny little joke which betrayed his pride about ' hanging out a service flag now.' Armed with interminable lists which called for supplies for twelve months, she bought her equipment. All the time she was saying to herself

" 'I am ready to give all of my youth and my strength to the cause and to hasten victory.'

"Then the armistice was signed. The wireless instrument sang with the message. There was a celebration. The ship remained dark, still sliding through the nights warily, but her next trip would be made with decks ablaze and portholes open. The war was ended. It seemed to the girl that in the silence of the aftermath she could hear once more the wings of freedom throbbing above the world. She was glad and she was sorry. Her fear was that after all the Red Cross would not need her because she came too late.

"Canteen service - she pictured the work minus the tonic of danger as a social job. Dressed in a blue smock and white coif she would bid a graceful farewell to the A. E. F. as it filtered out of. Europe. Now she smiles. Needed? Her fingers are scarred and she wonders if she ever will be able to pour one thousand bowls of coffee from the gigantic white procelain pitcher without blistering her hands.

"Each day she looks at the line of men jostling one another at the door. She listens to their interminable questions and comes to the full realization that she is one of the most important people in Paris, one of two hundred girls feeding thirty-five thousand soldiers daily.

"As some workers leaving for home after more than a year of service tell of making sandwiches under shell fire, of sleeping by the roadside in the woods to fool the boche flyers who bombed the Red Cross buildings, she still feels 
the sly nip of envy. But soldiers do not cease to be soldiers and heroes when the war is done.

"Other puddles formed on the table and she mopped them up. She had used three towels during her eighthour shift. A soldier, one of the thousands passing daily through the six Paris stations on their way home, journeying to leave areas, going to join the Army of Occupation or assigned to duty in the city, called to her.

"'Sister, I want to show you something,' he said, and unwrapped a highly decorative circlet of aluminum. It was a napkin ring which he had bought from a poilu who made it of scraps from the battlefield. There was an elaborate monogram engraved on a small copper shield.

" ' For my mother,' he explained. 'If you don't think it is good enough I will get something else.'

"At once fifty rival souvenirs were produced. Men came from other tables to exhibit their own. There was the real collector who bemoaned the theft of a 'belt made by a Russian prisoner in Germany and decorated with the buttons of every army in the world including the fire department of Holland.'

"One of the new arrivals had hands stiffened from recently healed wounds. She brought his plate of baked beans, roast meat, potatoes, a bowl of coffee, and pudding. A young Canadian with flaming, rosy cheeks divided the last doughnut with his friend, the Anzac. Crullers are the greatest influence in canteen for the general friendliness among soldiers of different armies. A League of Nations could be founded upon them if negotiations were left to the privates about the oilcloth-covered tables.

"The boy with the crippled hands protested that he did not want to accept a dinner for which there was so little charge.

" 'Say, Miss,' he said, 'I can pay more. I don't have to be sponging.'

" 'You have folks in the states?' she asked. He had. " 'Then,' she explained, 'they are the ones who sup- 
port the American Red Cross. When you come here it is because the folks asked you in to dinner.'

" ' But I haven't any folks,' announced a sailor.

“ ' I'm from the States, so I am your folks,' she retorted, ' and the Red Cross is your folks. We invite you to three meals a day as long as you stay in Paris.'

" 'You are my folks,' said the boy who was only a youngster, ' and you sure look like home to me.'

"The soldier with the crippled hands wanted to describe his wounds. Like hundreds of others he began with the sensations in the field, ' when he got his.' Deftly as she had learned to do during hundreds of such recitals, she cleaned up the table and stacked the plates without seeming to interrupt. It was three o'clock, the end of her day. She had reported at seven in the morning. The following week she would report with the other members of the staff at eleven at night because the doors of a canteen must never be closed.

" The boy talked on. He was explaining homesickness, the sort which drives men from cafés where the food is unfamiliar and the names on the menus cannot be translated into 'doughboy French' to such places as the little room in the Gare St. Lazare.

"She discovered that her habitual posture was with arms akimbo and hands spread out over her hips. This position seemed to rest the ache in her shoulders. Through her memory flashed pictures of waitresses in station eating houses who stood that way while tourists fought for twenty minutes' worth of ham and eggs between trains.

" Red Cross after-war canteens were a social center for pretty idlers in smart blue smocks?

"The smile on her lips never faltered and the hidden smile in her heart became a little song of laughter.

"She was 'helping' - helping in an 'eating joint,' some of the boys called it. But it was an eating joint with a soul."

What more could one ask of an eating-house? 
From the canteen at the railroad terminals - which were all right so far as they went - it was an easy step of transition to the establishment of hotels for the enlisted men in the accessible parts of Paris - until there was a total of six of these last, in addition to the five railway station canteens - at Gare St. Lazare, Gare du Nord, Gare d'Orsay, Gare d'Orléans, and Gare Montparnasse. The winter-time hotels were in the Avenue Victor Emanuel, Rue Traversière, Rue la Victoire, Rue St. Hyacinthe, and the Rue du Bac. These were all, in the beginning, small Parisian taverns of the pension type, which were rather quickly and easily adapted to their war-time uses.

The great difficulty with the first five of these American Red Cross doughboy hotels was their extreme popularity. They could hardly keep pace with the demands made upon them - in the last weeks that preceded and immediately following the signing of the armistice; while, with the coming of springtime and the granting of wholesale leaves of absence by the army, an immediate and most pressing problem confronted the American Red Cross in Paris. The boys were coming into the town - almost literally in whole regiments, and the provisions for their housing and entertainment there were woefully inadequate - to say the least. Not only were these accommodations, as furnished by the French, inadequate and poor, but the charges for them often were outrageous.

Yet to furnish hotel accommodations in the big town, even of the crudest sort, for a thousand - perhaps two thousand - doughboys a night was no small problem. There were no more hotels, large or small, available for commandeering in Paris ; the various allied peace commissions had completely exhausted the supply. Yet our Red Cross, accustomed by this time to tackling big problems and the solution of this was, after all, but part of the day's work, and because there were no more hotels or apartment houses or dormitories or barracks of any sort whatsoever available in the city of more than two million folks - our 
Red Cross decided to build a hotel. And so did - almost overnight.

It was a summer hotel, that super-tavern for our doughboys, and it stood squarely in the center of that famous Parisian playground, the Champs de Mars - and almost within stone throw of the Eiffel Tower and the Ecole Militaire. To create it several dozen long barracks - like American Red Cross standard khaki tents - were erected in a carefully planned pattern. Underneath these were builded wooden floors and they were furnished with electric lights and running water. A summer hotel could not have been more comfortable; at least few of them are.

The Tent City, as it quickly became known, was opened about March 4, 1919, with bed accommodations for 1,400 men, while preparations were quickly made to increase this capacity by another five hundred, for the latest and the biggest of American Red Cross hotels in Paris had leaped into instant popularity. Between six and nine-thirty in the morning and ten-thirty and midnight in the evening, the boys would come streaming in to the registry desk, like commercial travelers into a popular hostelry in New York or Philadelphia or Chicago. They would sleep - perhaps for the first time in many, many months - in muslin sheets. And these were as immaculate as those of any first-class hotel in the States.

There was no charge whatsoever for these dormitory accommodations. For the meals - simple but good and plentiful - the normal price of fifty centimes (nine or ten cents) was asked, but never demanded; while merely for the asking any of our boys in khaki could have at any hour the famous Red Cross sandwiches of ham or salmon or beef mixture or jam - chocolate or coffee or lemonade a-plenty to wash it down.

Definite provision was made for their amusement; there were "rubberneck wagons" to take them afield to the wonderful and enduring tourist sights of Paris and her environs - and at the Tent City itself a plenitude of shows 
and dances as well as the more quiet comfort of books or magazines, or the privilege and opportunity of writing a letter home.

"Of what use these last in Paris?" you ask.

Your point is well taken. I would have taken it myself - before I first went to the Tent City. When I did it was a glorious April day, the sun shone with an unaccustomed springtime brilliancy over Paris, and yet the air was bracing and fit for endeavor of every sort. Yet the big reading room tent of the Red Cross hotel in the Champs de Mars was completely filled - with sailor boys or boys in khaki reading the books or paper most liked by them. The sight astonished me. Could these boys - each on a leave of but three short days - be blind to the wonders of Paris ? Or was their favorite author particularly alluring that week? I decided to ask one of them about it.

"I saw Paris yesterday - Notre Dame, the Pantheon, Napoleon's Tomb, the Opera House, the Louvre, the Follies - the whole blame business. It's some hike. But I did it. An' to-day I'm perfectly satisfied to sit here and read these guys a-telling of how they would have fought the war."

Of such was the nature of the American doughboy.

Just as it was necessary at Treves and Bordeaux and elsewhere - because of the very volume of the problem to separate his entertainment from that of his officers, so it became necessary to effect a similar solution in Paris; for the officer is quite as much a ward of our Red Cross as the doughboy, himself. And so early in the solution of this entire great problem a superb home in the very heart of Paris - the town residence of the Prince of Monaco at No. 4 Avenue Gabriel and just a step from the Place de la Concorde - was secured and set aside as an American Red Cross Officers' Club. Lovely as this was, and seemingly more than generous in its accommodations, these were soon overwhelmed by the demands placed upon them, and steps 
were taken toward finding a real officers' hotel for the men of the A. E. F. when they should come to Paris.

These led to the leasing of the Hotel Lourre, at the head of the Avenue de l'Opera and almost adjoining the Comédie Française, the American University Union, and the Louvre. After being rapidly redecorated and otherwise transformed to meet the necessities of the A. E. F. it was reopened on the sixth of January, 1919, as the American Officers' Hotel in charge of Mr. L. M. Boomer, the directing genius of several large New York hotels. Mr. Boomer brought to the Red Cross a great practical hotel experience, and the house under his management quickly attained an overwhelming success. It had, in the first instance, been charmingly adapted to its new uses. Its rather stiff and old-fashioned interior had been completely transformed; there was all through the building an indefinable but entirely unmistakable home atmosphere. Our American officers fairly reveled in it.

Into this setting was placed good operation - a highgrade American-operated hotel, if you please, in the very heart of Paris and all her stout traditions. Petit déjeuners begone! They are indeed starvation diet for a hungry Yank. The breakfast in the American Officers' Hotel, which our Red Cross set up and operated, cost a uniform five francs (one dollar) and had the substantial quality of a regular up-and-doing tavern on this side of the Atlantic.

Before we rest, here are three typical bills of fare of a single ordinary day in this A. R. C.-A. E. F. establishment. The day was the nineteenth of April, 1919, and the three meals were as follows:

Breakfast

Five Francs - $(\$ 1.00)$.

Bananas

Quaker Oats

Eggs and Bacon

Griddle Cakes with Sirup

Confiture

Coffee, Cocoa, or Chocolate 


Luncheon Eight Francs - $(\$ 1.60)$.
Oyster Soup, with Okra
Scollops of Veal, Dewey
Nouilles, Milanaise
Cold Meats, with Jelly
Russian Salad
Raspberry Ice Cream
$\frac{\text { Coffee }}{\text { DrNNER }}$
Assorted Eclairs Ten Francs - $(\$ 2.00)$.
Crème St. Cloud
Rouget Portugaise
Roasted Filet of Beet, Cresson
Pommes Château Endive Flamandes
Salade de Saison
Candied Fruits Coffee Ice Cream
Coffee

Yet the charm of the American Officers' Hotel in Paris rested not alone in the real excellence of its cuisine, nor in the comfort of its cleanly sleeping rooms. It carried its ideals of genuine service far beyond these mere fundamentals. It recognized the almost universal Yankee desire to have one's shoes shined in a shop and so set up a regular American boot-blacking stand in one of its side corridors, a thing which every other Parisian hotel would have told you was quite impossible of accomplishment. It recognized the inconvenience of tedious waiting and long queues at the box office of the Paris theaters by setting up a theater ticket office in its lobby, which made no extra charge for the distinct service rendered. Nor was there a charge for the services of Miss Curtis, the charming little Red Cross girl, who went shopping with a fellow or for him, and who had a knack of getting right into those perplexing Paris shops and getting just what a fellow wanted at an astonishingly low price - for Paris in war times, anyway. Her range of experience was large; from the man with a silver star on each shoulder who wanted to buy a modish evening gown for his wife at a price not to exceed forty dollars, to the chunky Nevada lieutenant who had won 
three thousand francs at "redeye" on the preceding evening and was anxious to blow it all in the next morning in buying souvenirs for mother. With both she did her best. Her motto was that of the successful shop keeper: "We aim to please."

When Mr. Boomer had this hotel set up and running and turned his attention to some other housing problems of our Red Cross, the management fell to Major H. C. Eberhart, who had been his assistant in Paris and before that had been affiliated in a managerial capacity with several large American houses. He carried forward the job so well begun.

With the slow but very sure movement of our doughboys back from eastern France and Germany toward the base ports along the westerly rim of France, where they were embarking in increasing numbers for the blessed homeland, it became necessary for General Pershing to establish concentration areas, or reservoir camps, well back from the Atlantic Coast but convenient to it. By far the largest and most important of these was in the neighborhood of the city of Le Mans, some one hundred and fifty miles southwest of Paris, which meant in turn that what was finally destined to be the largest of the canteens of our American Red Cross in France outside of Paris was the final one established. It was known as the American Red Cross Casual Canteen and, situated within three blocks to the east of the railroad station at Le Mans, was a genuine headquarters for all the American soldiers for ten or fifteen or twenty miles roundabout. And in the bare chance that there might not be a doughboy who had chanced to hear of it, it was well indicated - by day, by a huge sign of the crimson cross, and by night that emblem blazing forth in all the radiance of electricity.

When the doors were finally opened - about the middle of March, 1919 - there were sleeping quarters under its hospitable roof for 250 enlisted men and forty officers. 
In the canteen portion of the establishment, 200 men could be served at a single sitting; in all 500 at each of the three meals a day. The comforts of this place almost approximated those of a hotel. When the men rose from their beds in the morning - clean sheets and towels and pillowcases, of course, even though it did mean that the Red Cross had to establish its own laundry in the establishment - they could step, quickly and easily, into a commodious washroom and indulge, if they so chose, in a shower bath. Eighteen showers were installed - for their convenience. It represented the acme of Red Cross service.

Finally the beginning of the end for the average doughboy in France - that long anticipated and seemingly never-arriving day of departure in the troopship for home.

Our Red Cross was down to see him off when he sailed. It might have been from Brest or Bordeaux or St. Nazaire that he took his departure - or from some one of the lesser ports that were used to a greater or less extent. That made no difference to the American Red Cross. It was part of its job to be on hand whenever and wherever the boy of the A. E. F. sailed for home - whether it was Brest or Vladivostok or Southampton or Marseilles.

As a matter of real and actual fact, Brest was the most used of all the embarkation ports for the journey home. It boasted what was sometimes called "the most beautiful canteen in France" which had been builded by our Red Cross, with the generous help of the army engineers. It immediately adjoined the embarkation sheds, and night and day in the months that followed the signing of the armistice, it was supremely busy - serving the inevitable cigarettes, doughnuts, chocolate, and other hot drinks. An interesting and extremely valuable adjunct to the place was a bakery, with a capacity of twenty thousand buns a day.

The enlisted men's rest room, with its bright hangings 
and draperies, its cartoons of army life painted upon its wall panels, its big fireplace, its comfortable settees, lounging chairs, and tables supplied with games, magazines, and writing material, held especial attraction for the doughboys. In all the mud and grime of the dirty Port du Commerce it was the one cheery and homelike place.

I told in an earlier chapter of the American Red Cross canteen at Bassens, just across the Gironde from Bordeaux. It is enough to add here and now that this American-builded port with its mile-long Yankee timber pier at which seven great ships might be berthed simultaneously, discharging or loading cargoes, never justified its worth half so much as in the days after the armistice. Thomas Kane's coffee attained a new perfection while Miss Susanne Wills, the Chicago woman who was directress of the canteen on the pier, and her fellow workers made renewed efforts to see that the boys that passed through the canteen had every conceivable comfort - and then some others. I, myself, spent a half day questioning them as to these. The verdict to the questionings was unanimous. It generally came in the form of a grin or a nod of the head, sometimes merely in a pointing gesture to the crimson-crossed comfort bag, that the big and blushing doughboy carried hung upon his wrist.

For the sick boy, going homeward bound from all the ports, very special comfort provisions were made - and rightly so. All of these last passed through the Red Cross infirmaries on the embarkation docks. As each went over the gangway he was questioned as to his equipment. If he was short a mess kit or a cup, a fork, a knife, a spoon or a blanket, the deficiency was promptly met; in addition to which each boy was given a pair of flannel pajamas and the inevitable comfort bag, with its toothbrush, tooth paste, wash cloth, bar of soap, and two packages of cig- 
arettes. Books and magazines also went upon each troopship, while Red Cross nurses accompanied the boys on to the ships and saw them safely settled in the hospital wards.

No mere cataloging of the work of our Red Cross in the embarkation ports can ever really begin to tell the story of the fullness of its service there. Charts of organization, details of operations, pictures of the surroundings go just so far, but never quite far enough to tell of the heart interest that really makes service anywhere and everywhere. Such service the American Red Cross rendered all across the face of France - and nowhere with more strength and enthusiasm than in those final moments of the doughboy which awaited him before his start home. Have I not already told you that our Red Cross over there was not a triumph of organization - or anything like it? It was a big job - and with big mistakes. But the bigness of the things accomplished so far outweighed the mistakes that they can well be forgotten; the tremendous net result of real achievement set down immutably and indisputably as a real triumph of our American individualism. 


\section{CH'APTER XII}

THE GIRL WHO WENT TO WAR

N the ship that bore me from New York to Europe in the first week of December, 1918, there were many war workers - and of many sorts and varieties. We had men and women of the Y. M. C. A., of the Y. W. C. A., of the Jewish Welfare Board, of the Knights of Columbus - and twenty-five women of the American Red Cross. And so, in the close-thrown intimacy of shipboard, one had abundant opportunity to study this personnel at rather short range, and the fact that our ship, which had been builded for South African traffic rather than for that of the North Atlantic, nearly foundered in mid ocean only served to increase the opportunity.

There were women war workers of nearly every age and variety in that motley ship's company. There were school-teachers - one from Portland, Maine, and another from Portland, Oregon - stenographers, clerks, women of real social distinction, professional women, including a well-known actress or two, and girls so recently out of finishing school or college that they had not yet attained their full places in the sun. Few of them had known one another before they had embarked upon the ship; there was a certain haziness of understanding in many of their minds as to the exact work that was to be allotted to them overseas. A large percentage of the women, in fact, had never before crossed the Atlantic; a goodly number had not even seen salt water before this voyage. Yet with all this uncertainty there was no timidity - no, not even when the great December storm arose, and with the fullness of its fury lashed itself into a hurricane the like of 278 
which our captain, who had crossed the ocean a hundred times or more, had not seen. And when the fury of this storm had crashed in the cabin windows, had torn the wheelhouse away, had set the stout ship awash and the passengers to bailing, the courage and serenity of these American women remained undisturbed. They suffered great personal discomforts, yet complained not. And with our national felicity for an emergency organization - that sort of organization really is part and parcel of our individualism - relieved the steward's crew at night and cooked and served the Sabbath supper.

There were women in uniform on our ship whose mouths were tightly shut in the grim determination of service one could fairly see "Z-E-A-L" written in unmistakable letters upon their high foreheads - and there were girls who fretted about the appearance of the curls under the edges of their small service caps and who coquetted with the young British aviators returning home after service as instructors on the flying fields here in the United States. Between these extremes there was vast range and variety. But the marvelous part of it all was that all of them each after her own creed or fashion, for the dominating quality of our individualism multiplies geometrically in the case of our American womanhood - ranged true to any test that might be put upon them. The storm showed that. I did not have the personal opportunity of seeing the Red Cross girls in battle service; but I did see them in the canteens in the hard, hard months that followed the signing of the armistice, saw them in the wards and the recreation huts of hospital after hospital, saw them, too, in Paris headquarters, working under very difficult conditions of light and ventilation - living of every sort - and at manual or office work or humdrum dreariness. The girl in uniform who sat all day in a poorly lighted and aired room at a typewriter or a filing case had a far less dramatic or poetic job than the traditional Red Cross girl who stands at a battlefield canteen or in a hospital ward holding 
the hand of some good-looking - and perhaps marriageable - young captain or colonel. Yet her service was as real as uncomplaining and - for the reasons we have just seen - vastly more difficult.

None of the women's work over there was easy - the romantic girl who went to France lured on by the dream pictures of some artist-illustrator as to the dramatic phases of canteen or hospital work was quickly disillusionized. The real thing was vastly different from the picture. A dirty and unshaven doughboy in bed or standing in a long queue waiting for his cigarettes or chocolate, and speaking Polish or Yiddish when he came to them, was a far, far different creature from the young wounded officer of the picture who must have been an F. F. V. or at least from one of the first families of Baltimore or Philadelphia. And the hours! They were fearfully hard - to put it lightly. Eight, ten, or twelve hours at a stretch was a pretty good and exhausting test of a girl's vitality. Nor was this all of the job, either. Many and many a woman worker of the Red Cross or, for that matter, the Y. M. C. A., too, has stood eight or ten or twelve hours on her feet in a canteen and then has ridden twenty or thirty miles in a truck or camionette to an army dance, has danced three or four or five more hours with soldier boys who, even if they do not happen to be born dancers, do covet the attention and interest of decent girls, and has returned to only a few hours of sleep, before the long turn in the canteen once again. And has repeated this performance four or five times a week. For what? Because she was crazy for dancing? Not a bit of it. For of a truth they became sick of dancing - "fed up" is the phrase they frequently used when they spoke of it at all.

"I feel as if I never wanted to hear an orchestra again," one of them told me one day as I stopped at her canteen - in a French town close to the occupied territory. "But I have four dates already for next week and three for the week after. Another month of this 
sort of thing and I shall be a fit candidate for a rolling chair."

"Why do you do it?" I ventured.

"Why do I do it?" she repeated. "The boys need us. Have you noticed the kind of girls that drift up here from Paris? If you have, you will understand why my job is unending, why it only pauses for a very little while indeed at night, when I jump into my bed for six or seven hours of well-earned sleep."

I understood. I had spent an evening in the grand boulevards of Paris and had watched a " $\mathrm{Y}$ " girl, under the escort of a member of the American Military Police, save foolish doughboys and their still more foolish officers - from themselves. In a few minutes after ten o'clock that evening an overcrowded hotel of one of our largest American war-relief organizations had regretfully turned away sixteen of our soldiers and in this time there were fifteen French girls waiting to give the hospitality that the sadly overburdened hotel had been compelled to refuse them. No wonder that our Red Cross was forced into the building of the great Tent City there on the Champs de Mars. As these French girls of the Paris streets came up to the doughboys the job of the "Y" girl began. In a few more minutes she had convinced the boys that it was not too late to give up hope of securing lodgings in overcrowded Paris; and was quick with her suggestions as to where they might be found. It was not a pleasant job. I hardly can imagine one more unpleasant. But the girl had her reward, in the looks of gratitude which the doughboys gave her. One or two of them cried like babies.

This was an unusual job to be sure. But our American Red Cross also was filled with unusual jobs for women as well as for men; jobs that took not merely endurance and courage, but in many, many cases rare wit and tact and diplomacy, and these were rarely lacking, and sometimes came where they were least expected. 
I am not all anxious to over-glorify these women. It would hardly be fair; for, after all, they were very human indeed - witness one young widow on our ship to Europe who not merely confessed but actually boasted that she had received three proposals of marriage upon that stormy voyage. And one little secretary girl from the Middle West, who was of our ship's company, wanted to be a canteen worker, although she was specifically enrolled for the office work for which she was particularly qualified, but when she found that the canteen to which she was to be assigned was located in a lonely railroad junction town in the middle of France, demanded that she be sent to Coblenz, where the Army of Occupation had its headquarters; she said quite frankly that she did not want to be robbed of all her opportunities of meeting the nice young officers of the army. She was very human, that young secretary, and eventually she got to Coblenz. Insistence counts. And she was both insistent and consistent.

But at the Rhine her lot, oddly enough, was not thrown in with officers but with the doughboys - the enlisted men of our most amazing army. She fed them, walked with them, danced with them, wrote their letters, and finally began to understand. And so slowly but surely came to the fullness of her real value to the country that she served.

One evening she dined in the Y. W. C. A. hostess house at Coblenz with two of these boys. Left alone, she would have dined by herself. She was tired, very tired. There comes the hour when a woman worker wearies a bit at sight of a ceaseless file of chattering and khaki-clad men. And so when she seated herself in one of the little dining booths of the "Y. W." restaurant, it was with a silent prayer that she might be left alone - just that evening. Her prayer was not granted. A big doughboy came and sat down beside her, another across the narrow table from her. The second vouched for the first. 
"You will like Hank," said he. "He's one of the livest in the whole First Division. He's from Waco, Texas, and say, he's the best gambler in the whole army."

At which Hank grinned and produced a huge wad of ten and twenty and fifty and hundred frane notes from his hip pocket.

"Don't you let him string you, Miss Tippitoes," said he, "but if ever you get where you need a little spare change you know where your Uncle Hank is to be found."

He called her "Miss Tippitoes" because he could not remember her real name even if ever it had been given to him. But he had danced with her and watched her dance, and marveled. And well might he have marveled. For if I were to give you Miss Tippitoes' real name you might know it as the name of the most graceful and popular dancer in a fashionable suburb of Chicago.

Hank edged closer to her. It was in the crowded restaurant, so he took off his coat and unbuttoned his blouse, as well as the upper buttons of his undershirt. And Tippitoes stood for it - it was a part of her job and she knew it - while Hank leaned closer to her and confided some of his troubles - they were troubles common to so many of the doughboys.

"It's a dump that we're billeted in, miss," said he," and it's all the fault of our colonel - him and that Red Cross girl he's stuck on. Just because he's got a mash on her he had the regiment moved in to G-. But I've got his number. And as for her - why, that girl comes from my home town. I've got hers, too."

Tippitoes' eyes blazed. She could have lost her temper so easily. It is not difficult when one is fagged and nerves begin to get on edge, but she kept her patience.

"Don't be foolish, young man," said she, "otherwise somebody will have to take the trouble to tell you that a colonel does not locate his regiment. He has no more to say about where you shall all be billeted than you your- 
selves. And as for the Red Cross girl, she is in the same position. Moreover, your remark is not worthy of an American soldier - and a gentleman."

There was something in the way she said these things - no type may ever put in upon paper - that, in the language of the motion-picture world, " registered." In a little time Hank was ashamed of himself, and with the innate generosity of his big, uncouth heart, apologized like a gentleman and an American soldier.

Ofttimes, even though with the American Army women were not permitted to go very close to the front line, the job the Red Cross girl was fraught with much real danger. The air raid was too frequent and too deadly a visitor not to have earned an awsome respect for itself. The tooth marks of Big Bertha still show all too plainly as horrid scars across the lovely face of Paris - the beauty of the world. The boche, as we all very well know, did not stop his long-distance warfare from the air even at the sight of the roofs which bore crimson crosses and so signified that they were hospitals and, under every condition of civilization and humanity, exempt from attack. The story of these hospital raids, with their casualty lists, not merely of American boys already sick and wounded, but of the wounding and killing of the men and women who were laboring to give them life and comfort, is already a well-known fact of record; yet even this was not all. Death never seemed far away in those hard months of 1917 and 1918 , and Death was no respector, either of persons or of uniforms or of sex. Upon the honor roll of our Red Cross there are the names of twenty-three American women, other than nurses, who made the supreme sacrifice for their country.

The experiences of the Red Cross girls in the air raids were as many and varied as the girls themselves. That of a canteen worker at Toul was fairly typical. She had been over at the neighboring city of Nancy to aid in one of the 
innumerable soldiers' dances which had been given there. In the middle of the dance it had suddenly occurred to her chum and herself that neither had eaten since morning. A young lieutenant had taken them to a very good little restaurant in the great Place Stanislas that all through the hard days of the war held to a long-time reputation of real excellence, and had insisted that they order a dinner of generous proportions.

Yet before their soup had been fairly served an air raid was upon them. The roar of the planes and the rattle of cannonading were continuous. Every light in the place went out instantly, and because the proprietor insisted even then in keeping his shades and shutters tightly drawn the place was inky black.

"What did you do?" I asked her.

"What did we do? We went ahead and ate our dinner. It was the best thing we could do. I realized for the first time in my life the real handicaps of the blind. I don't see how they ever learn to eat fried chicken gracefully."

-In an earlier chapter I told of the remarkable work done by the Smith College girls at the crux of the great German drive. It was impossible in that chapter to tell all of the sacrifice and the devotion shown by these women - the most of them from five to fifteen years out of college, although one of the best of them was from the class of 1882 and still another from that of 1917 . "We were an unbaked crew," one of them admitted quite frankly to me.

Miss Elizabeth Bliss was typical of these college girls. A long time after Château-Thierry they were all working behind the lines in the Argonne, Miss Bliss herself in charge of a sanitary train for the Red Cross from the railhead back to the base hospital. It was part of her job to work up to midnight and then be called at three o'clock in the morning to see the four o'clock train start off 
with its wounded. On one of those October mornings, when the weather was a little worse than usual, if that could be possible, she exerted a perfectly human privilege and decided not to get up.

But no sooner had this decision been made than the still, small voice spoke to her.

"Can you afford to miss even one day?" it said to her.

"I'm all in. I just can't get up," she replied to the S. S. V.

"Can you afford to miss - even one day?" it repeated. She got up and dressed and made her way down in the rain to the waiting train. As she went into the long hospital car a wounded doughboy raised himself on one elbow and shouted to all his fellows:

" Hi, fellows, I told you that a Red Cross girl would be here, and here she is. I told you she'd come."

"Just think if I hadn't," says Miss Bliss in telling of this incident.

When life back of the front was not dangerous or dramatic, it was apt to be plain dreary. There is not usually much drama just in hard wark. Take once again the case of Miss Mary Vail Andress, whom we found in charge of the canteen at Toul. Miss Andress came to France on the twenty-fourth of August, 1917, one of a group of seven Red Cross women, the first of the American Red Cross women to be sent over. The other members of the party were Mrs. Dickens, Mrs. Lawrence, Miss Frances Mitchell (who was sent to the newly opened canteen at Epernay), Miss Rogers, Miss Andrews, and Miss Frances Andrews, and were immediatcly dispatched to Châlons. For a short time Miss Andress was the assistant of Henry Wise Miller, who was then in charge of canteen work in France. She, however, enlisted for canteen work and so asked Mr. Miller to be allowed to go into the field and was sent to Epernay. From there she went back to Paris and on to Chantilly, 
where she prepared a home for girls in canteen work. She came to Toul in January, 1918, and, as you already know, was the first woman worker to reach that important American Army headquarters.

"For a while it seemed as if I could never quite get down to the real job," she says "it seemed so often that something new broke loose and always just at the wrong time. While we were working to get the first canteen established here at Toul - we had a nurses' club in mind at the time - word came from the hospital over there back of the hill that the Red Cross was needed there to help prepare for the comfort of the nurses in that big place. I went there at once - of course. Within fifteen minutes after I got there I was hanging curtains in the girls' barracks - couldn't you trust a woman to do a job like that? I did not get very many hung. Captain Hugh Pritchitt, my chief, came bursting in upon me. 'They're here.' he shouted.

"I knew what that meant. 'They' were the first of our American wounded, and they must have comfort and help and immediate attention. They got it. It was part of our job, you know. And after that part was organized there was nothing to it but to come back to Toul and set up our chain of canteens there."

And you already know how very well that particular war job was done. And doing it involved much devotion and endurance and self-sacrifice, not only on the part of the directress, but on that of her staff of capable assistants.

Talk about devetion and endurance and self-sacrifice! Into the desolate ruin of the war-racked city of Rheims there walked last October two American Red Cross women on a sight-seeing trip. They had had months of hard canteen work and were well tired out, and were about to return home. In a week or so of leave they went to Rheims because that once busy city with its dominating cathedral has become the world's new Pompeii. And the man or 
woman who visits France without seeing it has missed seeing the one thing of almost supreme horror and interest in the world to-day.

The two Red Cross women had but a single day to see Rheims. That was last October. They still are there; for back of the ruins, back of the gaunt, scarred hulk of that vast church which was once the pride of France, and to day the symbol of Calvary through which she had just passed, there rose the question in their minds: what has become of the folk of this town? It was the sort of question that does not down. Nor were the two women - one is Miss Emily Bennet of the faculty of a fashionable girls' school in New York and the other Miss Catherine Biddle Porter of Philadelphia - the sort that close their souls to questions such as these.

They found the answer. It was in the basement of the commercial high school - a dreary, high-ceilinged place, but because of its comparatively modern construction of steel and brick a sort of abri or bombproof refuge for the three or four hundred citizens that stuck it out through the four years of horror. In that basement place of safety an aged school-teacher of the town, Mademoiselle Fourreaux, month in and month out, prepared two meals a day bread and soup - for the group of refugees that gathered round about her and literally kept the heart of Rheims abeat. The Red Cross women found this aged heroine - she confesses to having turned seventy - working unaided, and within the hour were working with her, sending word back to Paris to send up a few necessary articles of comfort and of clothing. That night they slept in Rheims, and were billeted in a house whose windows had been crudely replaced with oiled paper and whose roof was half gone.

In a short time relief came to them. The American Red Cross sent in other supplies and workers and established a much larger and finer canteen relief in another section of the town. Other organizations - French and 
British and American - poured in relief; but Miss Bennett and Miss Porter stuck it out, and soon began to reap the fruit of their great endeavors.

I have cited here a few instances of women who have gone overseas - frequently at great personal sacrifices to help bear the burden of the war. If space had permitted I might easily have given five hundred, and each of them would have had its own personal little dramatic story. I might simply tell of some of the women whom I have met on the job; of Miss Lucy Duhring of Philadelphia, setting up the women's work of the Y. M. C. A. in the leave areas of the occupied territory; of a girl superintendent of schools from Kansas, working in the hospital records for the Red Cross at Toul; of another girl from Kingston-on-Hudson running a big Y. W. C. A. hotel for army girls in Paris and running it mighty well; of still another woman - this one a welfare worker from a big industrial plant in Kansas City - as the guiding spirit in the hostess house at Coblenz. The list quickly spins to great lengths. It is a tremendously embracing one, and when one gazes at it, he begins to realize what effect this great adventure overseas is going to have upon the lives of the women who participated in it; how it is going to change the conventions of life, or its amenities, or its opportunities. How will the weeks and months of camaraderie with khaki-clad men, under all conditions and all circumstances affect them? Many of the silly conventionalities of ordinary life and under ordinary conditions of peace, have, of necessity, been thrown away over there. Men and women have made long trips together, in train or in motor car, and have thought or made nothing of it whatever. On the night train up from Aix les-Bains to Paris on one of those never-to-be-forgotten nights the autumn the conflict still raged, two girls of the A. E. F. found it quite impossible to obtain seats of any sort. Four or five marines, back from a short leave in a little 
town near there, did the best they could for them and with their blankets and dunny rolls rigged crude beds for them in the aisle of a first-class car, and there the girls rode all night to Paris while the marines stood guard over them.

The gray-uniformed woman war-worker knows that she may trust the American soldier. Her experience with the doughboy has been large and so her tribute to the high qualities of his manhood is of very real value. Moreover, she too, has seen real service, both in canteen work and in the still more important leave area work which has followed - this last the great problem of keeping the idle soldier healthily amused.

"I have known our girls," she will tell you, "to go into a miserable little French or German town filled with a thousand or twelve hundred American boys in khaki and in a day change the entire spirit of that community. There has been a dance one night, for instance, with the boys restless and trying stupidly to dance with one another, or in some cases, even bringing in the rough little village girls from the streets outside. But the next dance has seen a transformation. The girls of the A. E. F. have come, they are dancing with the men; there is cheer and decency in the very air, there are neither French nor German present - the place is American.

"You have told of what the American girl has been to the men of our army; let me tell, in a word, what the army has been to the American woman who has worked with it: We have trusted our enlisted men in khaki and not once found that trust misplaced. Night and day have we placed our honor in their hands and never have trusted in vain."

"The reason why?" we venture.

"The mothers of America," is the quick reply.

I know what she means. I have read letter after letter written by the doughboys to the mothers back here, and the mass of them still stay in my mind as a tribute that all but surpasses description. Some of them mis- 
spelled; many of them ungrammatical - where have our schools been these last few years? - a few of them humorous, a few pathetic, but all of them breathing a sentiment and a tenderness that makes me willing to call ours the sentimental as well as the amazing army. Add to these letters the verbal testimony of the boys to the women of their army.

"We're not doing much," one after another has said. "but say, you ought to see my mother on the job back home. She's the one that's turning the trick."

It was a large experiment sending women with our army overseas - in the minds of many a most dubious experiment. In no other war had an army ever had women enrolled with it, save possibly a few nurses. It is an experiment which, so far as the United States is concerned, has more than justified itself. Our women have been tried in France - in other European lands as well - and have not been found wanting; which is a very faint way, indeed, of trying to tell of a great accomplishment. For if the American soldier, through many months of test and trial - and test and trial that by no means were confined to the battlefield - has kept his body clean and his soul pure through the virtue of woman which has been spread about him through the guarded years of his home life, how about the virtue of the women that, clad in the uniform of our Red Cross and the other war-relief organizations, guarded him successfully when he was far away from home? There is but one answer to such a question, but one question to follow after that. Here it is: Is it fair to longer consider such a real accomplishment a mere experiment? I think not. I think that it is rather to be regarded as a real triumph of our Americanism. 


THIS BOOK IS DUE ON THE LAST DATE STAMPED BELOW

\section{AN INITIAL FINE OF 25 CENTS} WILL BE ASSESSED FOR FAILURE TO RETURN THIS BOOK ON THE DATE DUE. THE PENALTY WILL INCREASE TO 50 CENTS ON THE FOURTH DAY AND TO \$1.00 ON THE SEVENTH DAY OVERDUE.

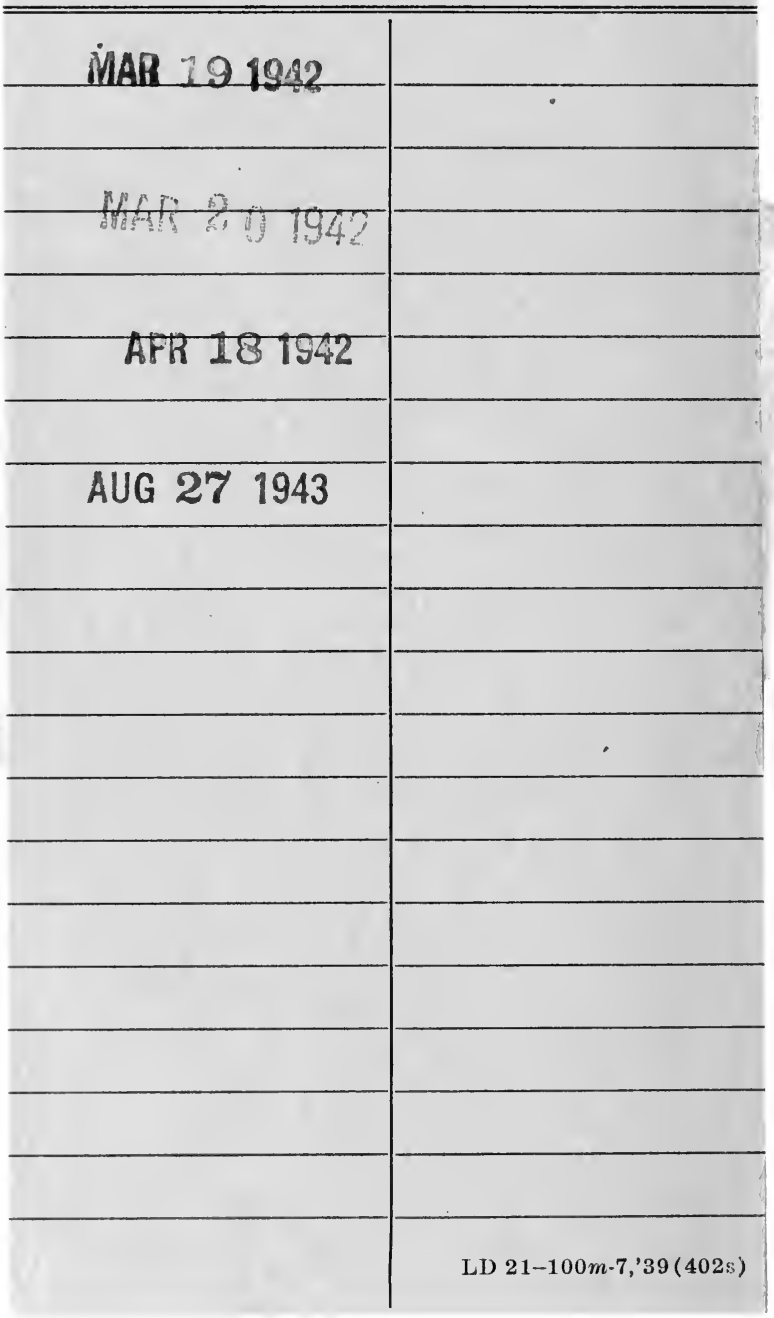




\section{YB 21182}

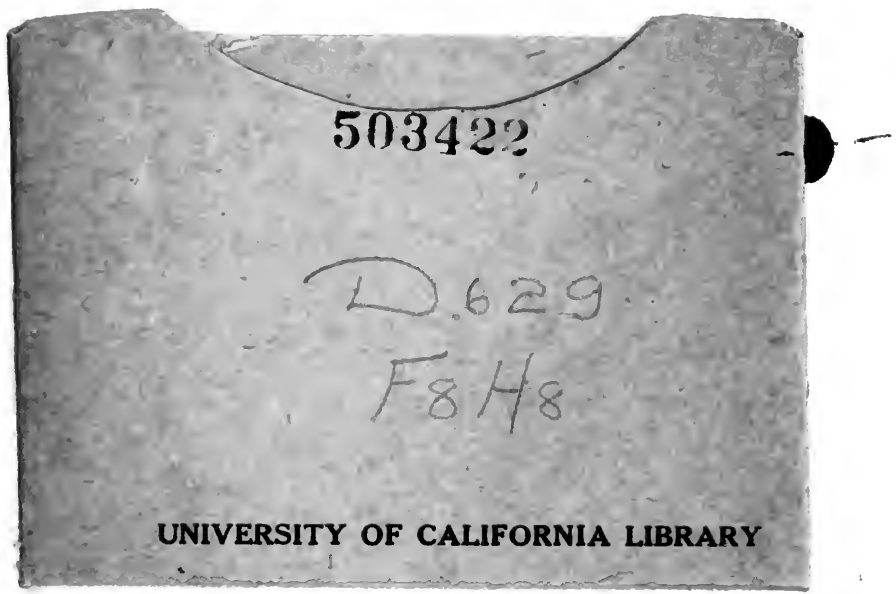




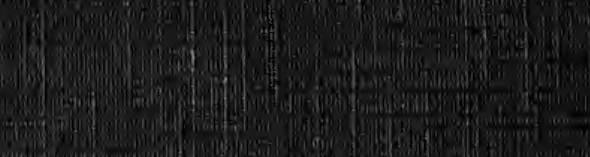

1.5. 